\title{
\#USGS
}

science for a changing world

2.:.

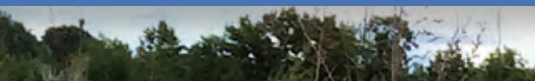

Prepared in cooperation with the Fisheries Management Program of the Wisconsin Departient of Netural Resourcess

Estimation of the Grouniwater Resources

of the Bedrock Aquifers at the Kettle Moraine Springs State Fish Hatchery, Sheboygan County, Wisconsin.
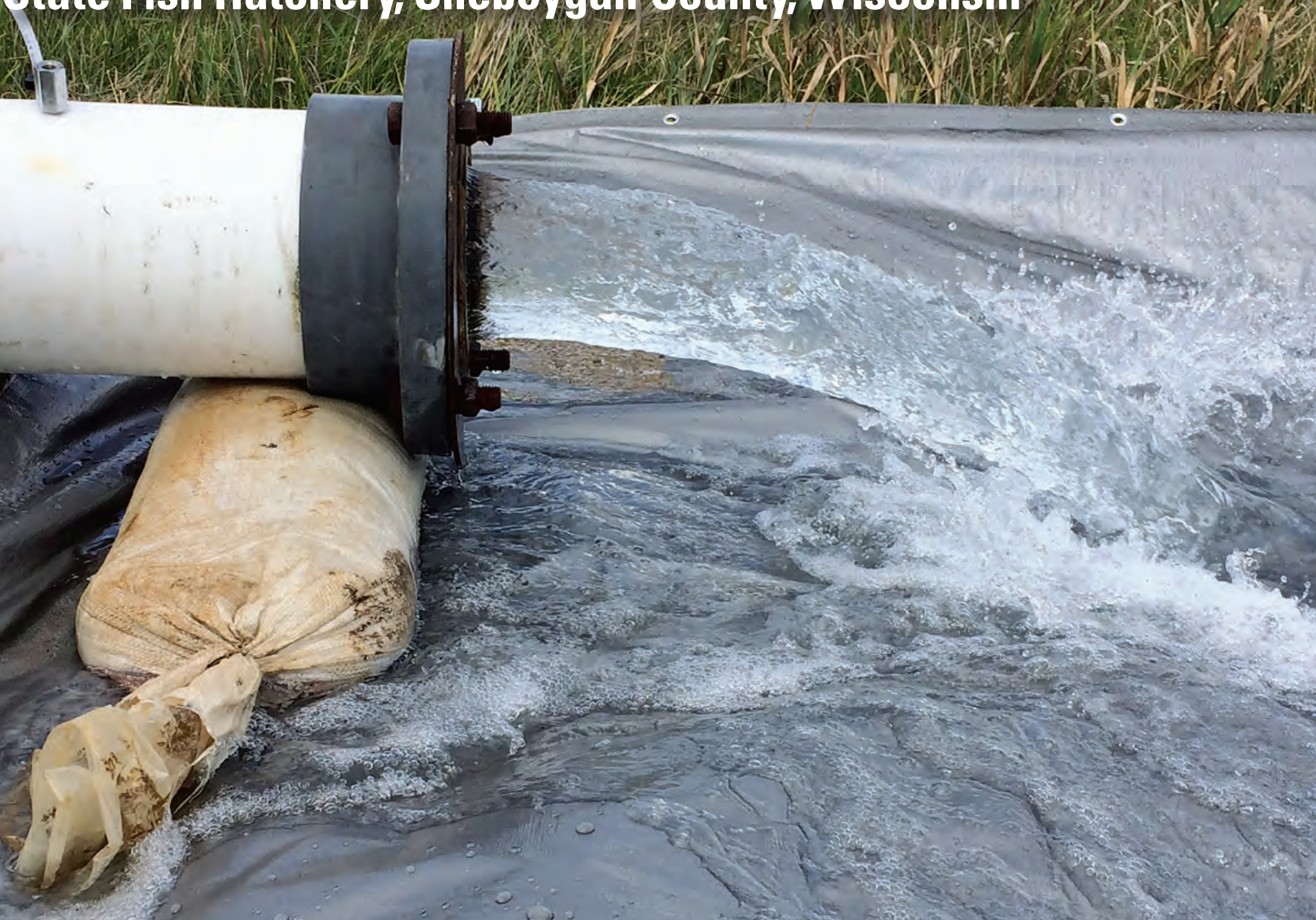

Scientific Investigations Report 2017-5074

U.S. Department of the-interior

U.S. Geologjoal Survey.

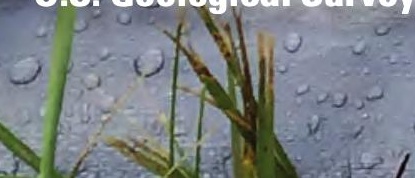


Cover photographs by Chuck Dunning, U.S. Geological Survey.

Front cover. Water being pumped from the Cambrian Ordovician Aquifer System during the aquifer pumping test conducted at the Kettle Moraine Springs State Fish Hatchery, Sheyboygan County, Wisconsin, 2015.

Back cover. Drilling the monitoring well at the Kettle Moraine Springs State Fish Hatchery, Sheyboygan County, Wisconsin, 2015. 


\section{Estimation of the Groundwater Resources of the Bedrock Aquifers at the Kettle Moraine Springs State Fish Hatchery, Sheboygan County, Wisconsin}

By C.P. Dunning, D.T. Feinstein, C.A. Buchwald, R.J. Hunt, and M.J. Haserodt

Prepared in cooperation with the Fisheries Management Program of the Wisconsin Department of Natural Resources

Scientific Investigations Report 2017-5074 


\title{
U.S. Department of the Interior \\ Ryan K. Zinke, Secretary
}

\section{U.S. Geological Survey William H. Werkheiser, Acting Director}

\author{
U.S. Geological Survey, Reston, Virginia: 2017
}

For more information on the USGS - the Federal source for science about the Earth, its natural and living resources, natural hazards, and the environment-visit https://www.usgs.gov or call 1-888-ASK-USGS.

For an overview of USGS information products, including maps, imagery, and publications, visit https://store.usgs.gov/.

Any use of trade, firm, or product names is for descriptive purposes only and does not imply endorsement by the U.S. Government.

Although this information product, for the most part, is in the public domain, it also may contain copyrighted materials as noted in the text. Permission to reproduce copyrighted items must be secured from the copyright owner.

Suggested citation:

Dunning, C.P., Feinstein, D.T., Buchwald, C.A., Hunt, R.J., and Haserodt, M.J., 2017, Estimation of the groundwater resources of the bedrock aquifers at the Kettle Moraine Springs State Fish Hatchery, Sheboygan County, Wisconsin: U.S. Geological Survey Scientific Investigations Report 2017-5074, 104 p., https://doi.org/10.3133/sir20175074.

ISSN 2328-0328 (online) 


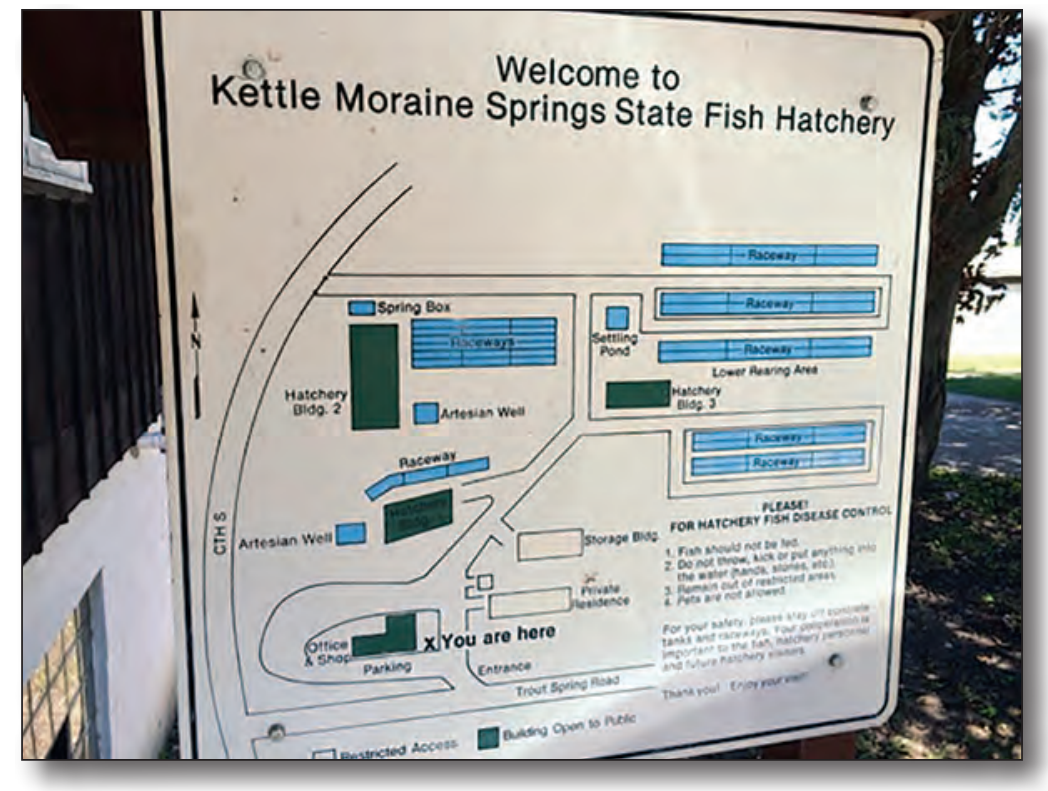

\section{Acknowledgments}

The authors would like to gratefully acknowledge the many contributors to the success of this effort. We owe a great debt to Paul Barlow, U.S. Geological Survey, for his guidance on applying optimization methods to managing water supply. The Wisconsin Department of Natural Resources (WDNR) Bureau of Fisheries Management and the staff of the Kettle Moraine Springs State Fish Hatchery are acknowledged for their enthusiastic support of the overall project and their invaluable assistance with well drilling operations and the aquifer pumping test. The scientists of the WDNR Groundwater Section played a critical role by contributing their expertise regarding local lithology and site conditions, ensuring that State regulations were followed, and resolving logistical issues. The authors appreciate the skill and persistence of the U.S. Geological Survey Western Drilling Group in artfully drilling two deep bedrock wells in an area in which there was very little precedent drilling to provide guidance. The Wisconsin Geological and Natural History Survey is acknowledged for frequent consultation on the glacial and bedrock stratigraphy of Sheboygan County and for their time and expertise in conducting geophysical logging of the monitoring well constructed in the Cambrian-Ordovician bedrock. The CTW Corporation, located in DePere, Wisconsin, provided advice and services for the aquifer pumping test. Badger Well Drilling, Inc. located in Mt. Calvary, Wisconsin, shared expertise and provided insight into local drilling conditions. Finally, we are especially grateful for the contribution of two graduate students from the University of Milano-Bicocca: Fabiola Buarne` who completed a thesis on modeling groundwater conditions at the Les Voigt State Fish Hatchery, and Anna Grava who completed a thesis on optimization modeling at the Kettle Moraine Springs State Fish Hatchery. 



\section{Contents}

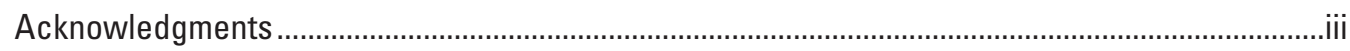

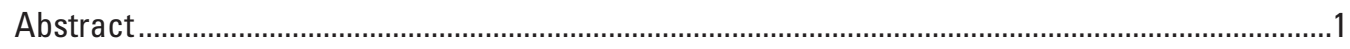

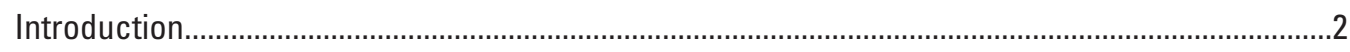

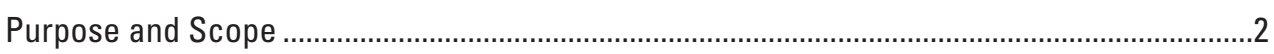

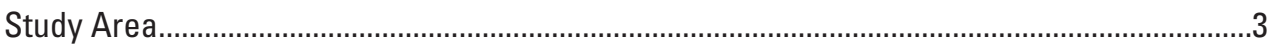

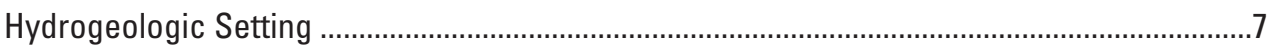

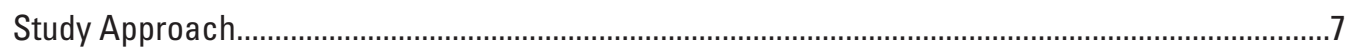

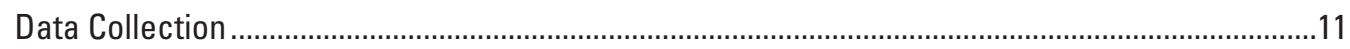

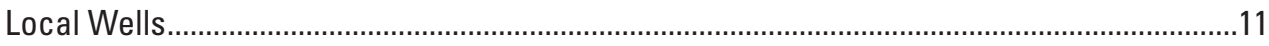

New Well Construction and Borehole Geophysics...........................................................11

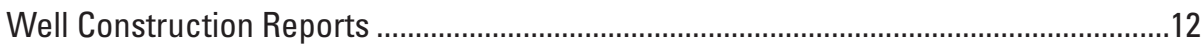

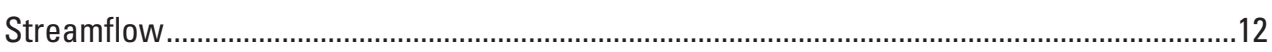

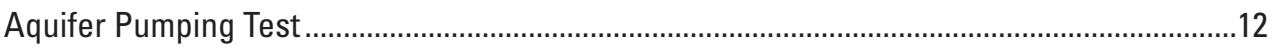

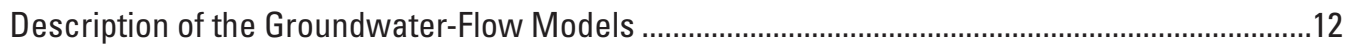

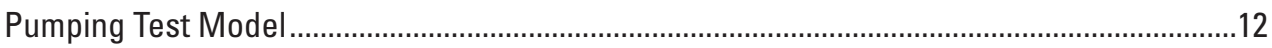

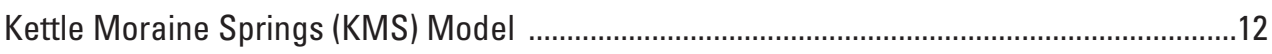

Lake Michigan Basin (LMB) Modified Model .................................................................13

Estimation of Water Supply from the Silurian Aquifer ..................................................................13

Steps in Estimating Water Supply from the Silurian Aquifer ................................................13

Estimated Water Supply from the Silurian Aquifer .................................................................14

Estimation of Water Supply from the Cambrian-Ordovician Aquifer System ...................................19

Pumping Test (PT) Model-Estimated Water Supply from the Cambrian-Ordovician Aquifer System ....................................................................19

Lake Michigan Basin (LMB) Modified Model-Regional Effects of Pumping

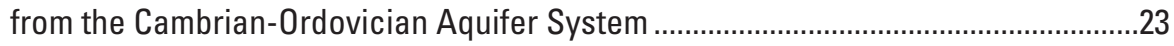

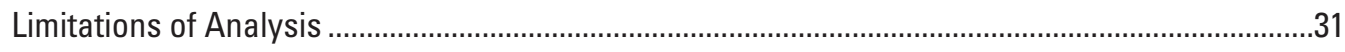

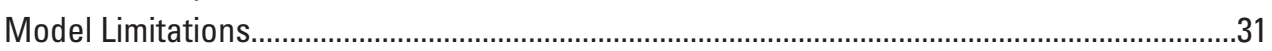

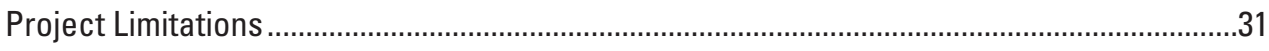

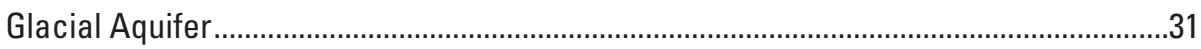

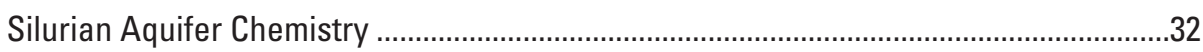

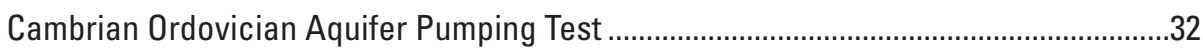

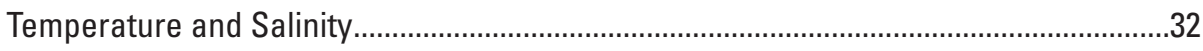

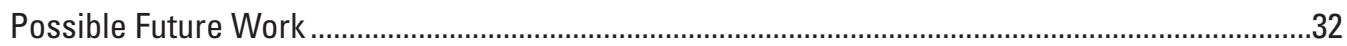

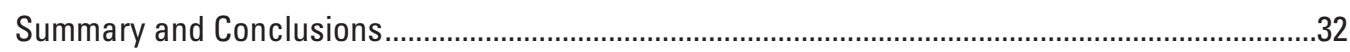

References Cited..................................................................................................................33

Appendix 1. Construction of a Test Production Well and a Monitoring Well in the Cambrian-Ordovician Aquifer System ..........................................................................35

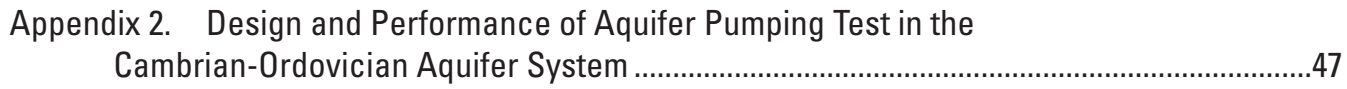

Appendix 3. Development of the Pumping Test Model and Interpretation of the Cambrian-Ordovician Aquifer System Pumping Test.........................................................51

Appendix 4. Development of the Kettle Moraine Springs (KMS) Model to Support Analysis of Silurian Aquifer Water Supply... 


\section{Contents-Continued}

Appendix 5. Application of the Pumping Test (PT) Model and the Lake Michigan Basin (LMB) Modified Model to Cambrian-Ordovician

Aquifer System Water Supply Scenarios.

Appendix 6. Application of Kettle Moraine Springs (KMS) Model to Silurian

Aquifer Water Supply Scenarios

\section{Figures}

1. Map showing the geographical provinces of Wisconsin and the location of Sheboygan County, Wisconsin .

2. Map showing the location of Sheboygan County, Wisconsin in relation to the Green Bay and Lake Michigan Lobes of the late Wisconsin Glaciation

3. Map showing the topography and surface water features surrounding the Kettle Moraine Springs State Fish Hatchery, Sheboygan County, Wisconsin .5

4. Map showing surface water features near the Kettle Moraine Springs State Fish Hatchery and location of the springs on and near the hatchery property, Sheboygan County, Wisconsin. .6

5. Section showing the bedrock stratigraphy of eastern Wisconsin. . .8

6. Map showing extent of the Cambrian-Ordovician aquifer system .9

7. Map of the Great Lakes region showing the Lake Michigan Basin (LMB) model domain, the Kettle Moraine Spring (KMS) model domain, and the Pumping Test model domain

8. Map of the Kettle Moraine Springs State Fish Hatchery showing the grid of the Kettle Moraine Springs model (KMS model), the six candidate locations for pumping from the Silurian aquifer, and the locations of drawdown and flow constraints to limit that pumping, Sheboygan County, Wisconsin

9. Map showing drawdown in the Silurian aquifer under the AllConstraints simulation of pumping from wells TOP2, TOP3, and ALT2 at a combined rate of 430 gallons per minute, Sheboygan County, Wisconsin

10. Map showing drawdown in the Silurian aquifer under the Contraints2 simulation of pumping from wells TOP1, TOP3, and ALT2 at a combined rate of 480 gallons per minute, Sheboygan County, Wisconsin.

11. Map showing drawdown in the Silurian aquifer under the Contraints3 simulation of pumping from wells TOP1, TOP3, and ALT2 at a combined rate of $\mathbf{5 2 0}$ gallons per minute, Sheboygan County, Wisconsin.

12. Map of the Kettle Moraine Springs State Fish Hatchery showing three candidate well locations for pumping from the Cambrian-Ordovician aquifer system, Sheboygan County, Wisconsin

13. Map of a portion of the Pumping Test model showing local drawdown in the Cambrian-Ordovician aquifer system after 20 years of pumping for Scenario 1 (two well cases), Sheboygan County, Wisconsin

14. Graphs showing the drawdown in production wells PW1 and PW2 pumping on a seasonal schedule for 20 years of Scenario 1 (two well cases), Sheboygan County, Wisconsin 


\section{Figures-Continued}

15. Map of a portion of the Pumping Test model showing local drawdown in the Cambrian-Ordovician aquifer system after 20 years of pumping for Scenario 2 (three well cases), Sheboygan County, Wisconsin

16. Graphs showing the drawdown in production wells PW1, PW2, and PW3 pumping on a seasonal schedule for 20 years of Scenario 2 (three well cases), Sheboygan County, Wisconsin...

17. Map showing location of Campbellsport production well \#4, the closest known well pumping from the Cambrian-Ordovician aquifer system, Wisconsin

18. Map showing simulated regional drawdown in the Cambrian-Ordovician aquifer system after 20 years of pumping for Scenario 1 (two well cases), Wisconsin

19. Hydrograph of simulated drawdown at Campbellsport production well \#4, 9.6 miles to the west of production well PW1, after 20 years of pumping for Scenario 1 (two well cases), Wisconsin.

20. Map showing simulated regional drawdown in the Cambrian-Ordovician aquifer system after 20 years of pumping for Scenario 2 (three well cases), Wisconsin

21. Hydrograph of simulated drawdown at Campbellsport production well \#4, 9.6 miles to the west of production well PW1, after 20 years of pumping for Scenario 1 (three well cases),Wisconsin

\section{Tables}

1. Pumping scenarios for the Silurian aquifer and the selected three most productive of six candidate well locations considering different constraints and listed in declining influence 


\section{Conversion Factors}

U.S. customary units to International System of Units

\begin{tabular}{|c|c|c|}
\hline Multiply & By & To obtain \\
\hline \multicolumn{3}{|c|}{ Length } \\
\hline inch (in.) & 2.54 & centimeter $(\mathrm{cm})$ \\
\hline inch (in.) & 25.4 & millimeter (mm) \\
\hline foot $(\mathrm{ft})$ & 0.3048 & meter $(\mathrm{m})$ \\
\hline mile (mi) & 1.609 & kilometer $(\mathrm{km})$ \\
\hline \multicolumn{3}{|c|}{ Area } \\
\hline square mile $\left(\mathrm{mi}^{2}\right)$ & 259.0 & hectare (ha) \\
\hline square mile $\left(\mathrm{mi}^{2}\right)$ & 2.590 & square kilometer $\left(\mathrm{km}^{2}\right)$ \\
\hline \multicolumn{3}{|c|}{ Flow rate } \\
\hline cubic foot per second $\left(\mathrm{ft}^{3} / \mathrm{s}\right)$ & 0.02832 & cubic meter per second $\left(\mathrm{m}^{3} / \mathrm{s}\right)$ \\
\hline gallon per minute (gal/min) & 0.06309 & liter per second $(\mathrm{L} / \mathrm{s})$ \\
\hline million gallons per day (Mgal/d) & 0.04381 & cubic meter per second $\left(\mathrm{m}^{3} / \mathrm{s}\right)$ \\
\hline inch per year (in/yr) & 25.4 & millimeter per year $(\mathrm{mm} / \mathrm{yr})$ \\
\hline \multicolumn{3}{|c|}{ Hydraulic conductivity } \\
\hline foot per day (ft/d) & 0.3048 & meter per day $(\mathrm{m} / \mathrm{d})$ \\
\hline \multicolumn{3}{|c|}{ Transmissivity* } \\
\hline foot squared per day $\left(\mathrm{ft}^{2} / \mathrm{d}\right)$ & 0.09290 & meter squared per day $\left(\mathrm{m}^{2} / \mathrm{d}\right)$ \\
\hline
\end{tabular}

Temperature in degrees Celsius $\left({ }^{\circ} \mathrm{C}\right)$ may be converted to degrees Fahrenheit $\left({ }^{\circ} \mathrm{F}\right)$ as follows:

$$
{ }^{\circ} \mathrm{F}=\left(1.8 \times{ }^{\circ} \mathrm{C}\right)+32 .
$$

Temperature in degrees Fahrenheit $\left({ }^{\circ} \mathrm{F}\right)$ may be converted to degrees Celsius $\left({ }^{\circ} \mathrm{C}\right)$ as follows:

$$
{ }^{\circ} \mathrm{C}=\left({ }^{\circ} \mathrm{F}-32\right) / 1.8 \text {. }
$$

\section{Datum}

Vertical coordinate information is referenced to the North American Vertical Datum of 1988 (NAVD 88) and National Geodetic Vertical Datum of 1929.

Horizontal coordinate information is referenced to the North American Datum of 1983 (NAD 83). Altitude, as used in this report, refers to distance above the vertical datum. 


\section{Abbreviations}

$\begin{array}{ll}\text { COAS } & \text { Cambrian-Ordovician aquifer system } \\ \text { DOD } & \text { Department of Defense } \\ \text { DRN package } & \text { Drain Package } \\ \text { GWM } & \text { Groundwater Management Process } \\ \mathrm{K}_{\mathrm{h}} & \text { Horizontal hydraulic conductivity } \\ \text { KMS model } & \text { Kettle Moraine Springs model } \\ \text { KMSSFH } & \text { Kettle Moraine Springs State Fish Hatchery } \\ \text { K }_{\mathrm{v}} & \text { Vertical hydraulic conductivity } \\ \text { LMB model } & \text { Lake Michigan Basin model } \\ \text { NWT package } & \text { Newton-Raphson solver package } \\ \text { PCG } & \text { Pre-conditioned conjugate gradient package } \\ \text { PT model } & \text { Pumping Test model } \\ \text { RIV package } & \text { River package } \\ \text { S } & \text { Storativity } \\ \text { SFR package } & \text { Stream Flow Routing Package } \\ \text { STR package } & \text { Stream Package } \\ \text { USGS } & \text { U.S. Geological Survey } \\ \text { WDNR } & \text { Wisconsin Department of Natural Resources } \\ \text { WEL package } & \text { Well package } \\ & \end{array}$





\title{
Estimation of the Groundwater Resources of the Bedrock Aquifers at the Kettle Moraine Springs State Fish Hatchery, Sheboygan County, Wisconsin
}

\author{
By C.P. Dunning, D.T. Feinstein, C.A. Buchwald, R.J. Hunt, and M.J. Haserodt
}

\section{Abstract}

Groundwater resources information was needed to understand regional aquifer systems and water available to wells and springs for rearing important Lake Michigan fish species at the Kettle Moraine Springs State Fish Hatchery in Sheboygan County, Wisconsin. As a basis for estimating the groundwater resources available, an existing groundwater-flow model was refined, and new groundwater-flow models were developed for the Kettle Moraine Springs State Fish Hatchery area using the U.S. Geological Survey (USGS) finite-difference code MODFLOW. This report describes the origin and construction of these groundwater-flow models and their use in testing conceptual models and simulating the hydrogeologic system.

The study area is in the Eastern Ridges and Lowlands geographical province of Wisconsin, and the hatchery property is situated on the southeastern edge of the Kettle Moraine, a north-south trending topographic high of glacial origin. The bedrock units underlying the study area consist of Cambrian, Ordovician, and Silurian units of carbonate and siliciclastic lithology. In the Sheboygan County area, the sedimentary bedrock sequence reaches a thickness of as much as about 1,600 feet $(\mathrm{ft})$.

Two aquifer systems are present at the Kettle Moraine Springs State Fish Hatchery. A shallow system is made up of Silurian bedrock, consisting chiefly of dolomite, overlain by unconsolidated Quaternary-age glacial deposits. The glacial deposits of this aquifer system are the typical source of water to local springs, including the springs that have historically supplied the hatchery. The shallow aquifer system, therefore, consists of the unconsolidated glacial aquifer and the underlying bedrock Silurian aquifer. Most residential wells in the area draw from the Silurian aquifer. A deeper confined aquifer system is made up of Cambrian- and Ordovician-age bedrock units including sandstone formations. Because of its depth, very few wells are completed in the Cambrian-Ordovician aquifer system (COAS) near the Kettle Moraine Springs State Fish Hatchery.
Three groundwater-flow models were used to estimate the water resources available to the hatchery from bedrock aquifers under selected scenarios of well placement and seasonal water requirements and subject to constraints on the effects of pumping on neighboring wells, local springs, and creeks. Model input data (recharge, water withdrawal, and boundary conditions) for these models were compiled from a number of data and information sources.

The first model, named the "KMS model," (KMS stands for Kettle Moraine Springs) is an inset model derived from a published USGS regional Lake Michigan Basin model and was constructed to simulate groundwater pumping from the semiconfined Silurian aquifer. The second model, named the "Pumping Test model," was constructed to evaluate an aquifer pumping test conducted in the COAS as part of this project. The Pumping Test model was also used to simulate the local effects of 20 years of groundwater pumping from this deep bedrock aquifer for future hatchery operations. The third model, named the "LMB modified model," is a version of the published Lake Michigan Basin (LMB) model that was modified with aquifer parameters refined in an area around the hatchery (approximately a 5-mile radius circle, corresponding to the area stressed by the aquifer pumping test). This LMB modified model was applied to evaluate regional effects of pumping from the confined COAS.

The available Silurian aquifer groundwater resource was estimated using the KMS model with three scenarios - named "AllConstraints," "Constraints2," and "Constraints3" - that specified local water-level and flow constraints such as drawdown at nearby household wells, water levels inside pumping well boreholes, and flow in local streams and springs. Each scenario utilized the MODFLOW Groundwater Management Process (GWM) to select three locations from six candidate locations that provided the greatest combined flow while satisfying the constraints. The three constraint scenarios provided estimates of 430 gallons per minute (gal/min), $480 \mathrm{gal} / \mathrm{min}$, and $520 \mathrm{gal} / \mathrm{min}$ pumping from three wells-AllConstraints, Constraints2, and Constraints3, respectively. The same three wells were selected for the scenarios that estimated $480 \mathrm{gal} / \mathrm{min}$ and $520 \mathrm{gal} / \mathrm{min}$; the scenario that estimated $430 \mathrm{gal} / \mathrm{min}$ shared two of these same wells, but the third selected well was different. 
The available COAS groundwater resource was estimated by two scenarios with each conducted over a period of 20 years with the Pumping Test model and the LMB modified model. The Pumping Test model was used to simulate local effects of pumping, and the LMB modified model was used to simulate regional effects of pumping. The scenarios simulate a range of total and seasonal pumping rates potentially linked to site activities. Scenario 1 simulates two wells completed in the Cambrian-Ordovician aquifer system, each pumping for 8 months at $300 \mathrm{gal} / \mathrm{min}$, followed by pumping for 4 months at $600 \mathrm{gal} / \mathrm{min}$. The average yearly pumping rate of Scenario 1 is $800 \mathrm{gal} / \mathrm{min}$. Scenario 2 simulates three wells completed in the Cambrian-Ordovician aquifer system pumping for 8 months at $200 \mathrm{gal} / \mathrm{min}$, followed by pumping for 4 months at $500 \mathrm{gal} / \mathrm{min}$. The average yearly pumping rate of Scenario 2 is $900 \mathrm{gal} / \mathrm{min}$. The Pumping Test model simulations confirmed that drawdown in the boreholes of the pumping wells at the selected 2-well or 3 -well rates will meet the desired condition that the pumping water level remains at least $100 \mathrm{ft}$ above the highest CambrianOrdovician unit open to the well.

The LMB modified model was used to evaluate the regional drawdown of the pumping from the confined COAS under the same 2-well and 3-well scenarios. At the nearest known existing COAS well, Campbellsport production well \#4, the simulated drawdown for Scenario 1 after 20 years of cyclical pumping with two pumping wells averaging a total of $800 \mathrm{gal} / \mathrm{min}$ is $16.9 \mathrm{ft}$, whereas the simulated drawdown for Scenario 2 after 20 years of pumping with three pumping wells averaging a total of $900 \mathrm{gal} / \mathrm{min}$ is $19.0 \mathrm{ft}$. The total deep aquifer thickness at the Campbellsport location is on the order of $620 \mathrm{ft}$, meaning that the simulated drawdown for either scenario is about 3 percent of the confined aquifer thickness.

The models developed as part of this project are archived in the project data release. The archive includes the model input and output files as well as MODFLOW source code and executables. (Haserodt and others, 2017).

\section{Introduction}

As part of the Wisconsin Department of Natural Resources (WDNR) fish production system that annually stocks about 7.2 million fish into waters of the State, the Fisheries Management Program operates 13 fish hatcheries and rearing stations across the State. Sport fishing annually brings more than 330,000 nonresident anglers to Wisconsin-a number exceeded by only Florida and Michigan. Sport fishing supports 22,000 jobs in Wisconsin and annually generates $\$ 2.3$ billion in economic benefits and \$148 million in State and local tax revenues (Wisconsin Department of Natural Resources, 2014).

In recognition of the importance of recreational fishing to the economy of Wisconsin and the importance of fish stocking as a fisheries management tool, the WDNR Bureau of Fisheries Management commissioned a study that resulted in the report "Comprehensive Study of Wisconsin's Fish Propagation
System" (Wisconsin Department of Natural Resources, 2010). An important conclusion of the study was that most of the fish production facilities of the WDNR need extensive renovation to meet fish stocking goals; however, hatchery renovation and design decisions are dependent on the quantity and quality of the water supply that is sustainably available. Another critical finding of the study was that most Wisconsin hatcheries lack adequate water supplies to support the volume of rearing space that already exists. Therefore, the WDNR Bureau of Fish Management recognized the importance of quantifying the amount of water that is sustainably available from local resources to meet the needs of planned operations at each of the fish hatcheries and rearing stations in Wisconsin.

With this need in mind, the WDNR funded this detailed study of the water resources available to the Kettle Moraine Springs State Fish Hatchery (KMSSFH) in Sheboygan County, a cold water fish production facility focused on stocking important Lake Michigan species. These species are Chinook (Oncorhynchus tshawytscha) and Coho (Oncorhynchus kisutch) salmon and Chambers Creek and Ganaraska River strains of steelhead (Oncorhynchus mykiss) trout. The KMSSFH, along with the Les Voigt State Fish Hatchery in Bayfield County, have been prioritized by the WDNR because both are critical to providing fish stock to the Great Lakes, and both are directly affected by regulatory requirements intended to protect high-quality surface waters such as trout streams and springs. The estimate of groundwater resources at the KMSSFH provided by this study will enable the WDNR Bureau of Fisheries Management to better understand groundwater availability from regional aquifers. This estimate also will assist the WDNR Bureau of Fisheries Management in their determination of resource sustainability and their ability to meet applicable regulatory requirements.

\section{Purpose and Scope}

The purpose of this report is to document the estimation of groundwater resources available to the WDNR at its KMSSFH and to describe the hydrogeologic data and groundwaterflow models that have been used to make this estimate. In particular, this report describes the refinement and application of a published U.S. Geological Survey (USGS) regional model for estimating the groundwater resources available from the local bedrock aquifers and describes the development of a model used specifically to analyze a pumping test performed on the Cambrian-Ordovician aquifer system (COAS). This report also provides a summary of aquifer pumping test data that were used to calibrate and modify the models of the COAS. Finally, the report documents an inset model (extracted from a published regional model) that is centered on the hatchery site and is designed to evaluate groundwater resources from shallow bedrock. Scenarios of aquifer, well locations, and pumping rates that were evaluated by the groundwater-flow models are presented in the report, describing options for water supply available to hatchery wells and springs. 
The report is organized as a main body followed by six appendixes. The main body of the report provides general background information and a description of the hydrogeologic setting of the KMSSFH, followed by a discussion of the major findings of the study. References are made to the appropriate appendixes in which readers can find the technical details of various study elements that support the major finding. This organization was adopted in order to present the information of most interest to the target audience unencumbered by the supporting material that is likely of interest to a smaller audience.

\section{Study Area}

The KMSSFH is in southwestern Sheboygan County, which falls within the Eastern Ridges and Lowlands geographical province of Wisconsin (fig. 1) (Martin, 1916). The $\mathrm{KMSSFH}$ is situated on the southeastern edge of a hilly region called the Kettle Moraine, a topographic high that trends roughly north-south in the eastern quarter of the State. The Kettle Moraine region formed "20,000 to 19,000 years ago between the thinning Green Bay and Lake Michigan Lobes" of the late Wisconsin Glaciation (fig. 2) and "is interpreted to

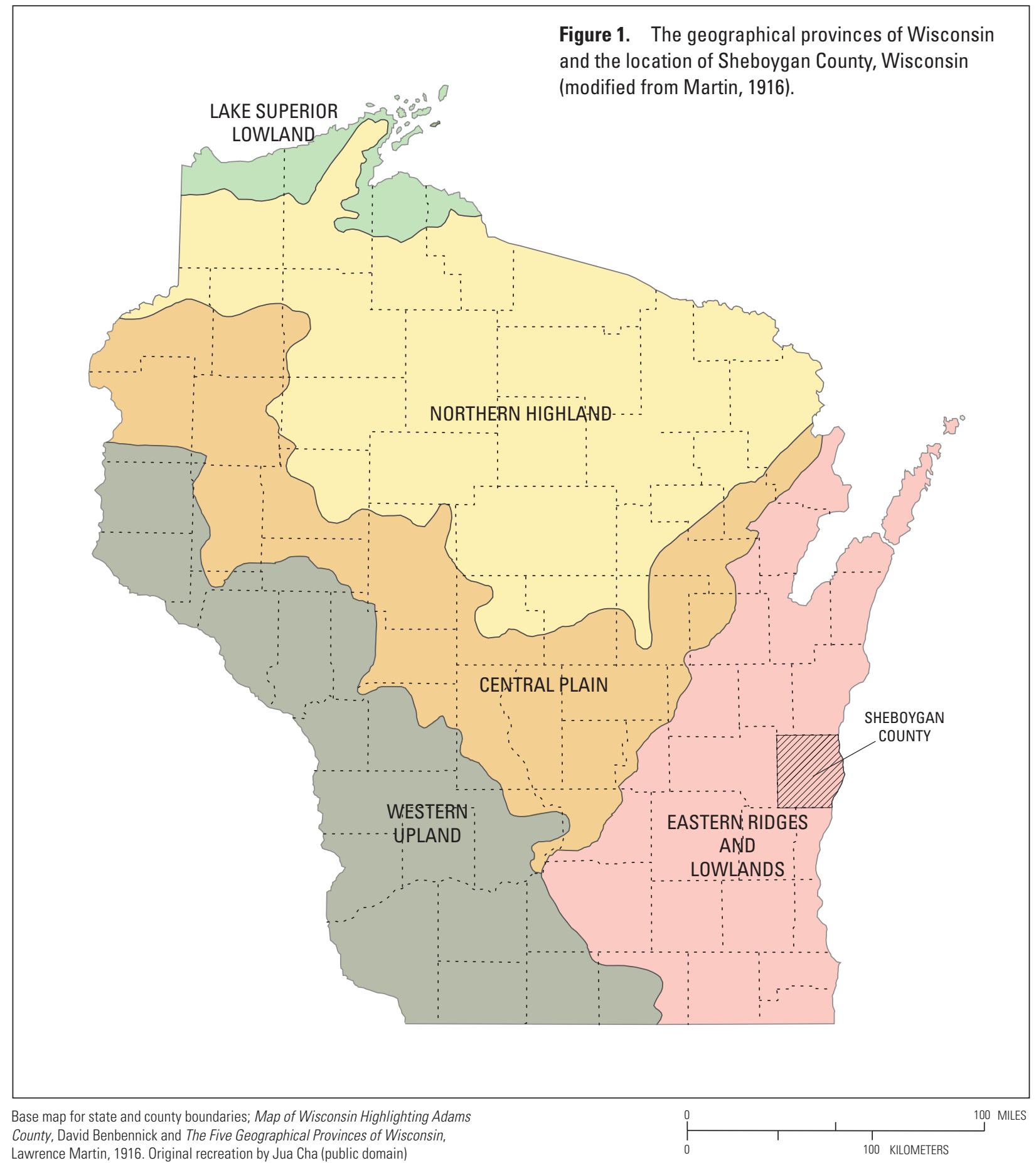




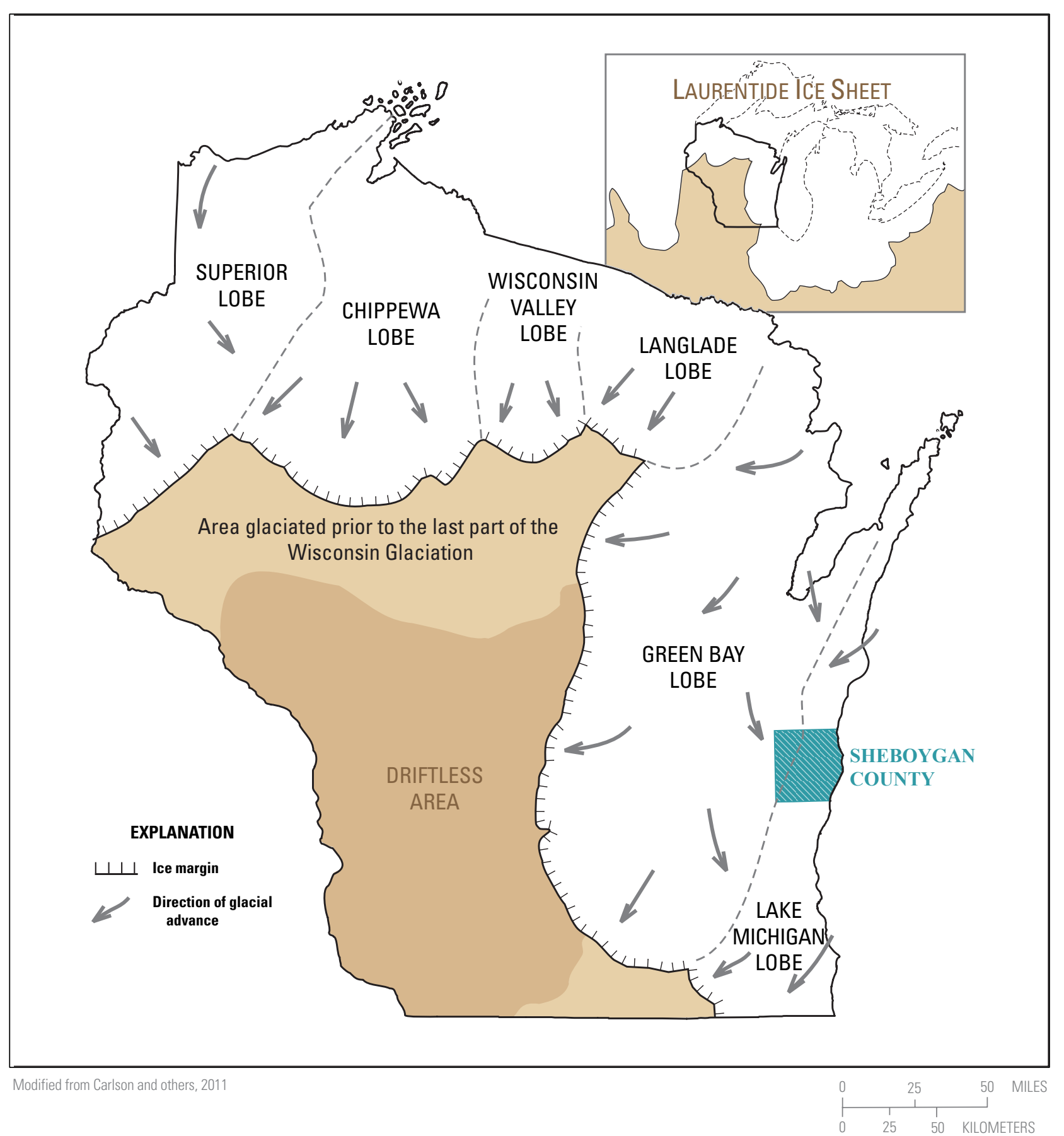

Figure 2. Sheboygan County, Wisconsin, in relation to the Green Bay and Lake Michigan Lobes of the late Wisconsin Glaciation (figure modified from Carlson and others, 2011).

have been a large braided river system on top of stagnant ice" (Carlson and others, 2011). To the east of the Kettle Moraine "lie regions of outwash and till. The primary glacial landforms of this region are drumlins, pitted outwash plains, large meltwater channels, and lake plains" (Carlson and others, 2011). This description fits the general geomorphology of the KMSSFH area.

The hills of the Kettle Moraine west of the KMSSFH reach an altitude of approximately 1,100 feet (ft) above North American Vertical Datum of 1988 (NAVD 88) (fig. 3).
Adjacent to the hatchery are lower, mostly wooded hills to the north, west, and south. Local valleys, with altitudes of about $850 \mathrm{ft}$ above NAVD 88 , are cultivated to raise crops for dairy farms. The surface-water features nearest to KMSSFH are Mink Creek and Melius Creek, which are adjacent to the hatchery to the west and east, respectively (fig. 4). Melius Creek flows roughly northeast to join the North Branch of the Milwaukee River. Mink Creek flows generally southwest and joins the North Branch of the Milwaukee River at a point further downstream. 


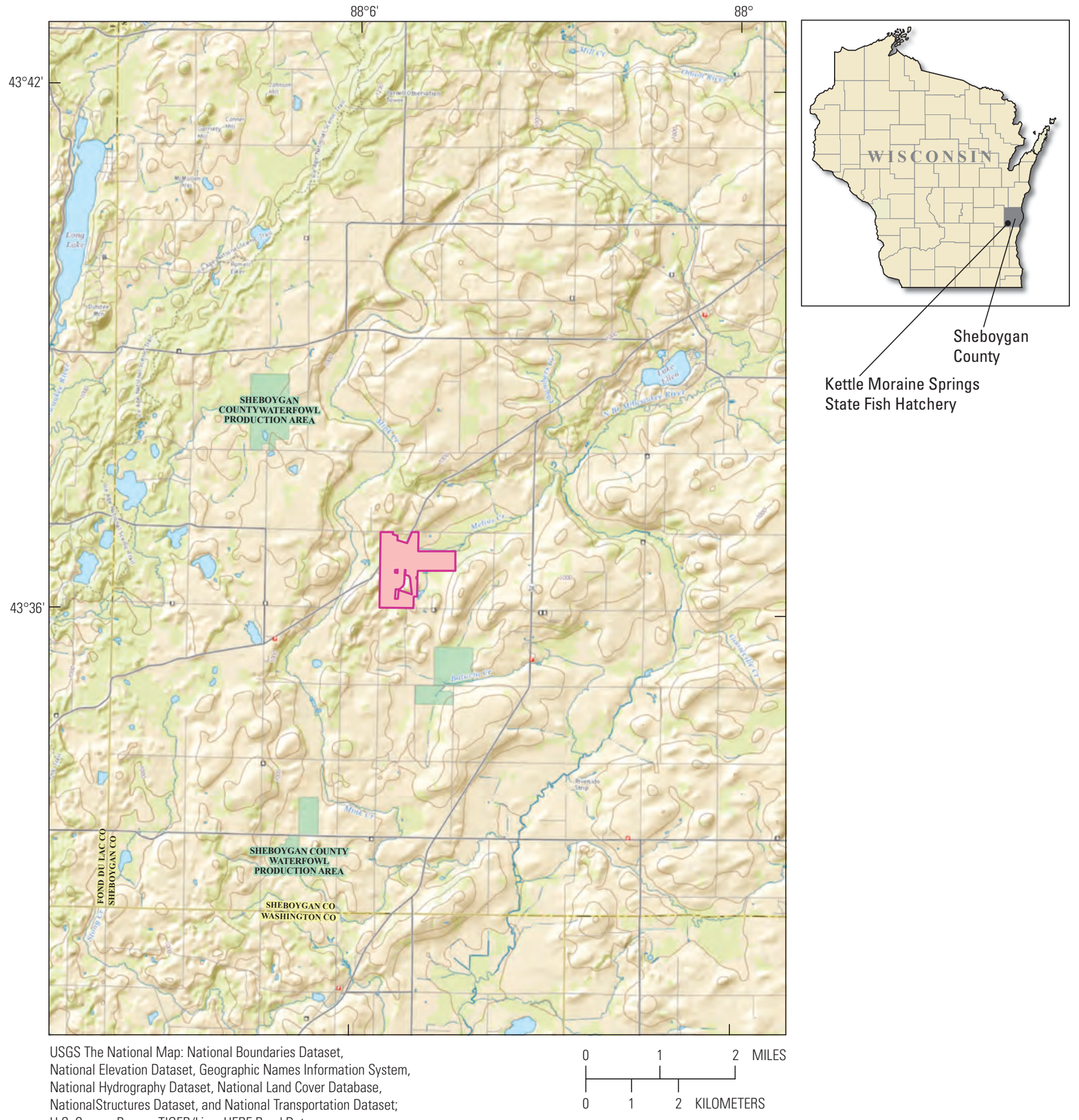

NationalStructures Dataset, and National Transportation Dataset;

EXPLANATION

Kettle Moraine Springs

State Fish Hatchery

Figure 3. Topography and surface-water features surrounding the Kettle Moraine Springs State Fish Hatchery, Sheboygan County, Wisconsin. 


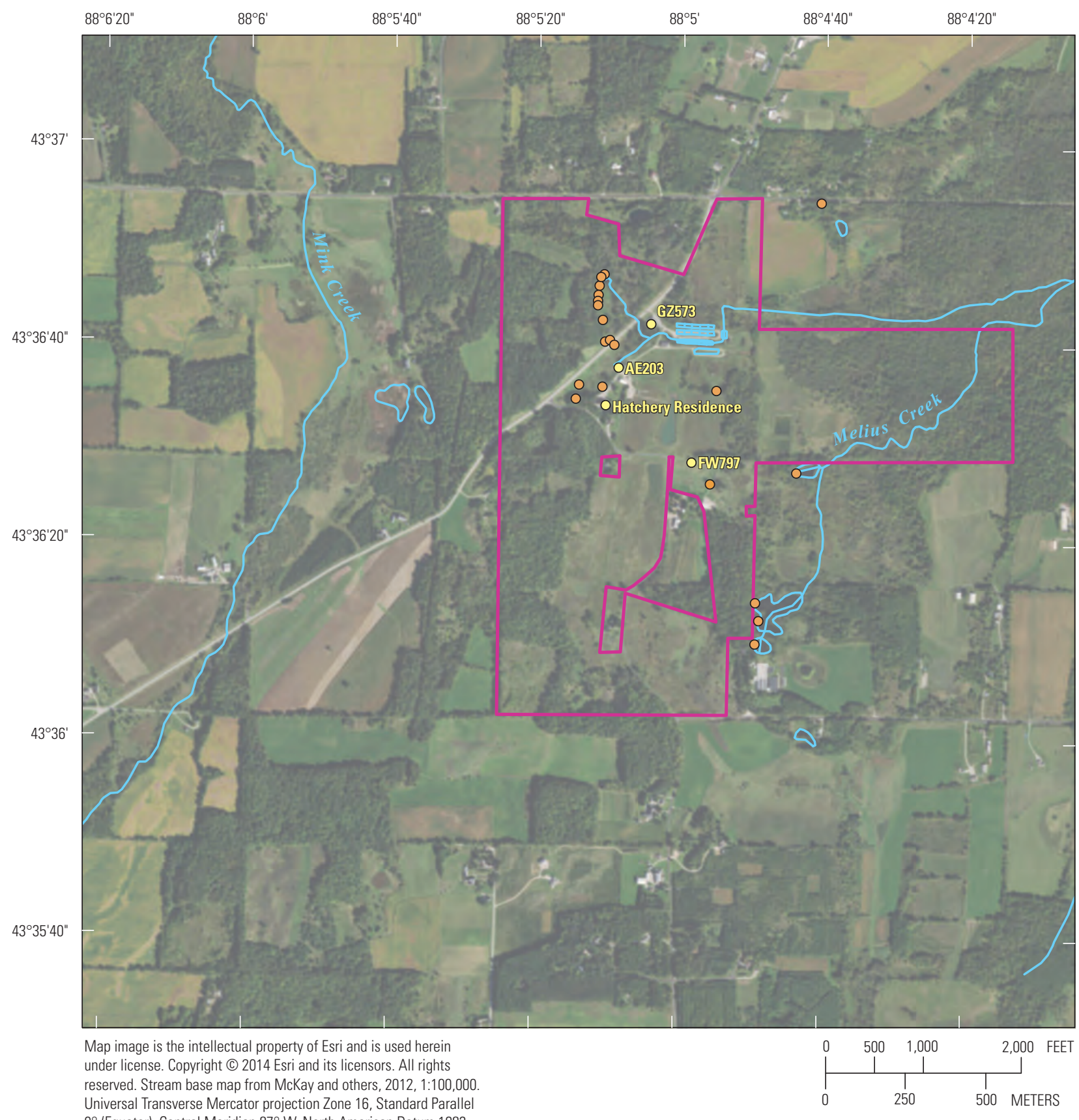

Universal Transverse Mercator projection Zone 16, Standard Parallel

EXPLANATION

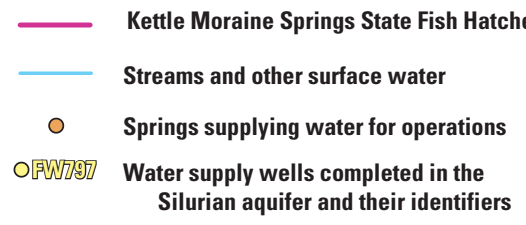

Figure 4. Surface-water features near the Kettle Moraine Springs State Fish Hatchery and location of the springs on and near the hatchery property, Sheboygan County, Wisconsin. 
Eighteen significant springs are present on the hatchery grounds and surrounding area that collectively are the headwaters of Melius Creek. The springs on the hatchery grounds (fig. 4) provide a majority of the current water needs of the hatchery. Spring boxes have been constructed for most of these springs, which collect and divert the natural spring flow to the hatchery. The spring flow has slight seasonal variability but typically provides between 550 and 600 gallons per minute $(\mathrm{gal} / \mathrm{min})$ to the hatchery.

\section{Hydrogeologic Setting}

In southern Sheboygan County, as for most of eastern Wisconsin, the Cambrian-Ordovician sequence of sandstone, siltstone, shale, and carbonate bedrock units overlies Precambrian crystalline bedrock (fig. 5). Silurian dolomites are the youngest bedrock units present in the area and unconformably overlie the Ordovician rocks (Wisconsin Geological and Natural History Survey, 2011; Luczaj, 2013). In the Sheboygan County area, the entire sedimentary bedrock sequence ranges in thickness from about 1,200 to 1,600 ft. Overlying the bedrock units are Quaternary-age deposits, primarily unconsolidated glacial deposits of varying lithologic character, that typically range from less than 100 to as much as $350 \mathrm{ft}$. The stratigraphic names used in this report conform to those established by the Wisconsin Geological and Natural History Survey (2011).

Two aquifer systems are present at the KMSSFH: (1) an upper unconfined or semiconfined system, and (2) a deeper confined system. The upper aquifer system consists of the Silurian-age bedrock and overlying unconsolidated Quaternary-age glacial deposits. The glacial aquifer is a mixture of lithologies ranging from sand and gravel deposits to heterogeneous diamicton. The Silurian sequence is characterized as dolostone that commonly exhibits fractures and secondary permeability (Luczaj, 2013). Because the Silurian bedrock is in direct contact with the overlying glacial deposits, the two aquifers are hydraulically connected and conceptually represent the upper aquifer system. The nature of this connection was documented in a study conducted by the USGS in 1992 (Conlon, 1995). The Silurian aquifer is considered to be locally confined by fine-grained glacial material, but in general, pumping from this aquifer is expected to interact with local surface-water features. The water table present in the upper aquifer system typically falls within the glacial deposits in the vicinity of the hatchery, and it is the springs present in the glacial deposits that are currently the primary water supply for the hatchery. With only a few exceptions, local wells in the vicinity of the hatchery are completed in either the Silurian bedrock or glacial deposits.

Operations at the KMSSFH rely on spring flow from the glacial units and shallow wells completed in the Silurian units. Total available flow from the upper aquifer system is variable and subject to drought conditions, ranging from about
470 to $1,545 \mathrm{gal} / \mathrm{min}$ with an average of about $700-900$ $\mathrm{gal} / \mathrm{min}$ (Andrew Hron, Wisconsin Department of Natural Resources, oral commun., August 2014). The water produced from the Silurian aquifer contains elevated levels of naturally occurring iron and hydrogen sulfide, which necessitates blending with the spring water for use in the hatchery.

The second aquifer system available to the hatchery is the COAS. The COAS is regional in extent, present in at least six States in the Midwest, and is made up of a sequence of sandstone, siltstone, shale, and carbonate rock (figs. 5 and 6). The COAS is separated from the upper aquifer system by the Maquoketa Shale, which is an effective confining unit in this area of Wisconsin (Feinstein and others, 2010) and is about $238 \mathrm{ft}$ thick at the hatchery (appendix 1). Because of the presence of the Maquoketa Shale, the COAS is considered to be hydraulically confined and because of its depth, the COAS previously has not been used for water supply at the hatchery. Figure 6 shows the regional extent of the COAS and illustrates that Sheboygan County is considered an area of generally higher salinity (modified from Wilson, 2012). This interpretation reflects work by Kammerer (1998) and is based on data from the few available wells completed in the COAS.

This study of the KMSSFH focuses on only the two bedrock aquifers: (1) the unconfined/semiconfined Silurian aquifer, and (2) the confined Cambrian-Ordovician aquifer. The springs sourced by the glacial deposits have been supplying the hatchery for many years, and the flow rates and variability of the springs are well known. In this study, the glacial aquifer has been considered only insofar as it influences the response to pumping from the Silurian aquifer.

\section{Study Approach}

This study estimates the groundwater resource of the bedrock aquifers at the KMSSFH using groundwater-flow modeling approaches. Three distinct numerical finite-difference models were used to simulate groundwater flow under stress from hatchery pumping scenarios.

A regional finite-difference model developed by the USGS for simulating groundwater flow in the Lake Michigan Basin (LMB) (Feinstein and others, 2010) was used by 2 of the 3 bedrock groundwater-flow models as their starting point. The model is solved with the SEAWAT version of MODFLOW (Langevin and others, 2007). This finite-difference code takes account of the effects of salinity and non-uniform fluid density, especially important in the deeper parts of the Michigan stratigraphic basin, on simulated heads and fluxes. This regional MODFLOW model, which has a near-field cell size of $5,000 \mathrm{ft}$ on a side, is referred to in this report as the LMB model (fig. 7) and was the basis for models used to (1) simulate local effects of pumping from the Silurian aquifer, and (2) simulate regional effects of pumping from the COAS. 


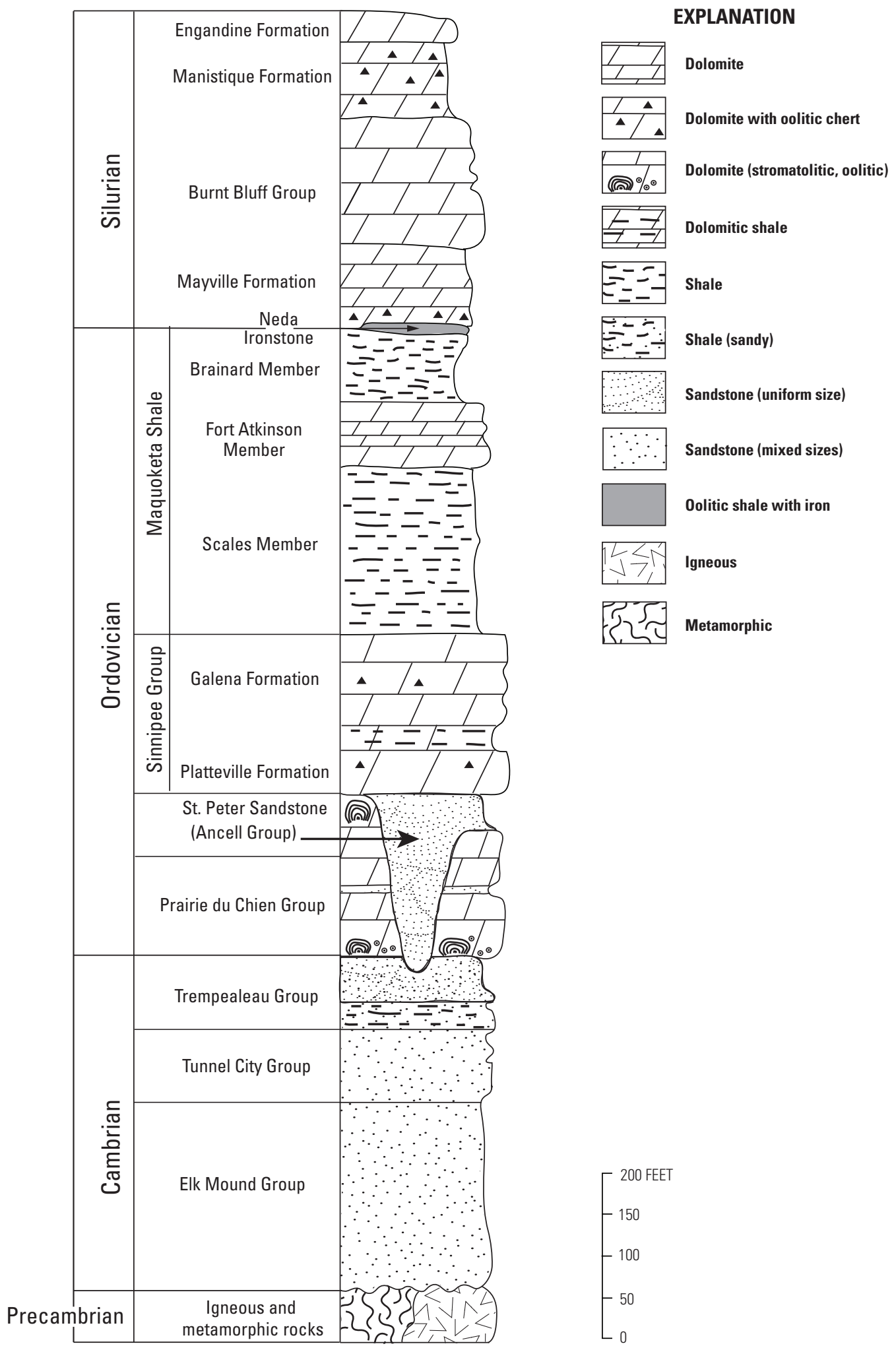

Figure 5. The bedrock stratigraphy of eastern Wisconsin (modified from Luczaj, 2013). 


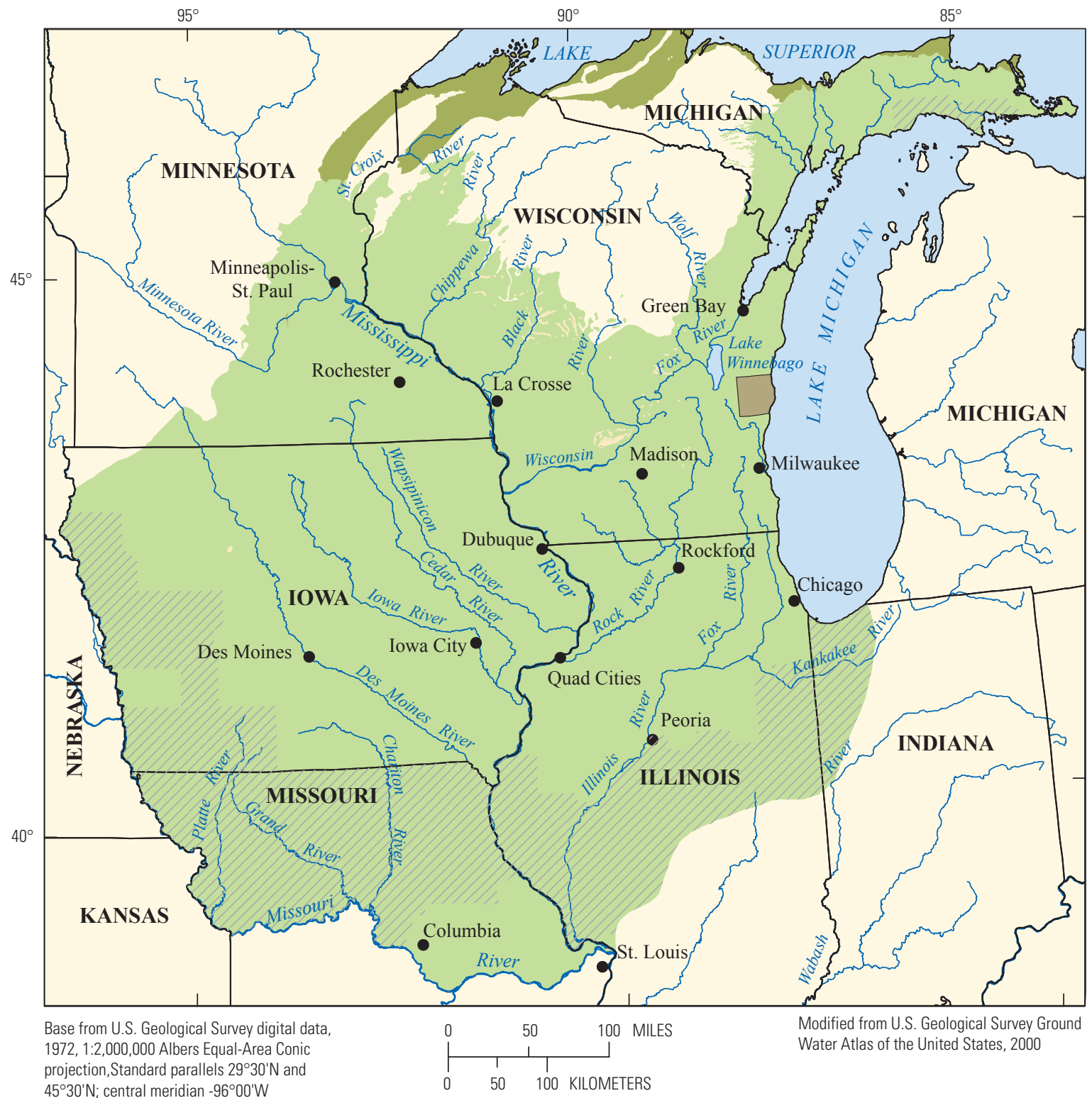

\section{EXPLANATION}

Cambrian-Ordovician aquifer system-

Counties hachured where aquifer system not used because of high salinity

\section{Precambrian sandstones}

\section{Sheboygan County}

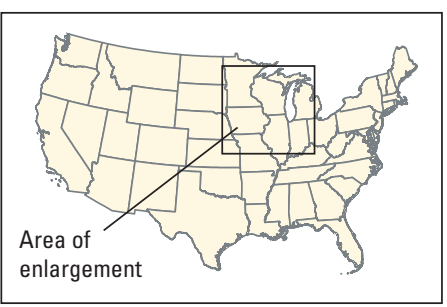

Figure 6. Extent of the Cambrian-Ordovician aquifer system (modified from Wilson, 2012) 


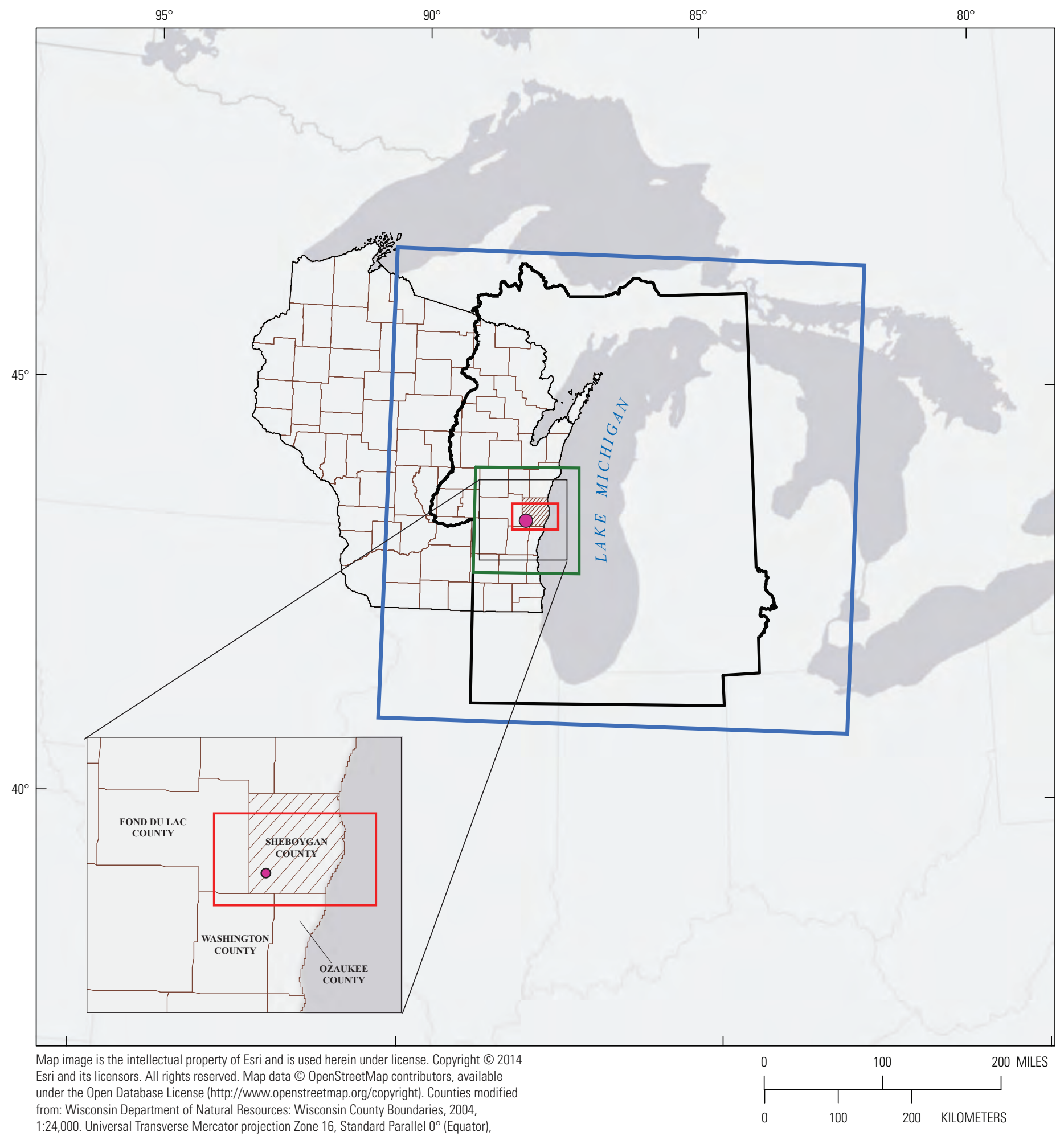

1:24,000. Universal Transverse Mercator projection Zone 16. Standard Parallel $0^{\circ}$ (Equator)

Central Meridian 87 W, North American Datum 1983

EXPLANATION
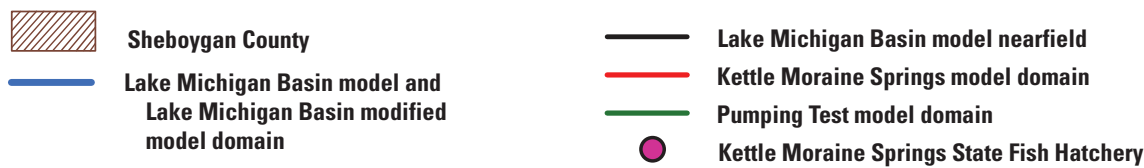

Figure 7. View of the Great Lakes region showing the Lake Michigan Basin (LMB) model domain, the Kettle Moraine Spring (KMS) model domain, and the Pumping Test model domain. 
In the first case, the LMB model was used as the basis for constructing an inset model with refined discretization to represent all the aquifers in the vicinity of the hatchery location including the Silurian aquifer. This new model is named the KMS model and its domain is a rectangular area covering parts of Sheboygan, Ozaukee, Fond du Lac, and Washington Counties in Wisconsin (fig. 7). This inset model used a cell size of $250 \mathrm{ft}$ on a side in order to better simulate local effects of pumping from the Silurian aquifer. The Silurian aquifer in the KMS model domain does not contain saline water. The KMS model is not solved with SEAWAT but with a uniform-density version of MODFLOW called MODFLOWNWT (Niswonger and others, 2011), which incorporates the Newton-Raphson method to accurately simulate unconfined conditions in the shallow part of the flow system containing the Silurian aquifer.

In the second case, the LMB model was used with its original regional domain, grid discretization, and SEAWAT code but with local changes to hydrogeological parameter values of the confined COAS. This model was used to simulate the regional effects of pumping from the COAS and is named the "LMB modified model" (fig. 7). The model was primarily used to evaluate the effect that pumping would have on simulated water levels in the nearest COAS well-a production well at Campbellsport located 9.6 miles (mi) west of the hatchery.

The changes to the hydrogeologic parameter values for the LMB model, updated to the LMB modified model, were based on the results of an aquifer pumping test conducted in the COAS as part of this study. The results of the aquifer pumping test were evaluated by a third finite-difference model created for this study, named the "Pumping Test model" (fig. 7). The Pumping Test model was used to calibrate aquifer parameters to the observations of the aquifer pumping test and to simulate the local effects of pumping from the COAS below the hatchery property. The origin and construction of these three models are discussed in greater detail later in the report and in related appendixes.

These three groundwater-flow models - the KMS model, the LMB modified model, and the Pumping Test model — were used to estimate the water resources available to the hatchery from bedrock aquifers under selected scenarios of well placement, seasonal water requirements, and subject to constraints on the effects of pumping on neighboring wells, local springs, and creeks.

\section{Data Collection}

Various types of hydrologic and geologic data and information were compiled or collected to be used as input to the groundwater-flow models. The data types are discussed below.

\section{Local Wells}

The majority of wells in the area, including hatchery wells and local residential wells, draw water from the Silurian dolomite aquifer. A smaller number of wells draw water from the glacial deposits in the region; the closest known well is $5 \mathrm{mi}$ from the hatchery. There are four wells on hatchery property that are completed in the Silurian aquifer: (1) at Hatchery Building 1 (Wisconsin Unique Well Number [WUWN] AE203), (2) at Hatchery Building 2 (WUWN GZ573), (3) near Peter Farm (WUWN FW797), and (4) the well that supplies the hatchery office and residence (unknown WUWN, labeled as Hatchery Residence) (fig. 4). WUWN AE203 is the only well currently used for hatchery operations and is used seasonally to supplement spring flow. This well is artesian at a low rate but is pumped to provide flow of $70-100 \mathrm{gal} / \mathrm{min}$; total pumpage was $18,144,000$ gallons in 2013. The closest known well that is completed in the COAS is a production well in the town of Campbellsport, located $9.6 \mathrm{mi}$ from the KMSSFH test well.

\section{New Well Construction and Borehole Geophysics}

As part of this study, two wells were drilled and completed in the COAS on the hatchery grounds. These wells were drilled and constructed by the USGS Research Drilling Program based in Las Vegas, Nevada (discussed in appendix 1).

At a first location, a borehole was drilled to a depth of $1,239 \mathrm{ft}$ below ground level (bgl). In this borehole, a nest of two 2-inch (in.) wells was completed, with one well screened within the COAS and the other well screened within the Silurian aquifer. The 2-in. well completed in the COAS, named "MW," was used as the monitoring well for the aquifer pumping test. It was completed to a depth of 1,238 ft bgl and logged to a depth of $1,237 \mathrm{ft}$ bgl. At a second location, a $103 / 4-i n$. diameter steel casing was set from the surface to $580 \mathrm{ft}$ bgl in the Ordovician Maquoketa Shale. This borehole was completed as a $97 / 8$-in. diameter open hole well from 580 to $1,020 \mathrm{ft}$ bgl. This well, named "PW1," was pumping during the aquifer pumping test. Appendix 1 provides additional details on the drilling and construction of these wells and the borehole geophysical data that were collected. 


\section{Well Construction Reports}

Data and information on the glacial and bedrock aquifers underlying the KMS model domain were critical to creating the best possible representation of the aquifers for the groundwater-flow modeling effort. Much information on stratigraphy and static water levels is provided by well construction reports (WCR); these reports are required to be submitted to the WDNR following the construction of every new well. The WCRs for 73 wells completed in the Silurian aquifer were identified for the local study area and were used to refine the altitude of the top of the Silurian bedrock for the refined KMS.

\section{Streamflow}

Streamflow was measured at seven sites near the hatchery during February 2014. Because of the time of year, these measurements were considered to represent base flow for the purposes of this study. These streamflow measurements were among hydrologic targets used in the calibration of the KMS model.

\section{Aquifer Pumping Test}

The two wells constructed in the COAS for this study, PW1 and MW, were used to conduct an aquifer pumping test. The interpretation of this test was critical to the calibration of the Pumping Test model and consequent modification of the LMB groundwater-flow model. The aquifer pumping test was conducted at the KMSSFH from September 11 to September 18, 2015. The test included a 6-hour step-drawdown test, recovery, a subsequent 72 -hour constant-rate test, and about 12 days of monitored recovery. Water levels were measured in both PW1 and MW during pumping and through the period of recovery ending on September 30, 2015. The pumping test confirmed the estimated pumping rates the aquifer could sustain and provided data that were used to refine values of aquifer hydraulic properties in the Pumping Test model and the LMB modified model.

Appendix 2 provides additional details on the design and performance of the aquifer pumping test. Appendix 3 provides details on the interpretation of the aquifer pumping test and its application to the modeling effort in the COAS.

\section{Description of the Groundwater-Flow Models}

Three ground-water flow models are described in this section. Each model contributes part of the analysis of water availability for the Kettle Moraine Springs State Fish Hatchery. The three models discussed are archived in the project data release (Haserodt and others, 2017).

\section{Pumping Test Model}

The Pumping Test model (PT model) was newly constructed for this study and features a nonuniform grid centered on the location of well PW1 constructed in the deep aquifer (see appendix 3). This central model grid node is $4 \mathrm{ft}$ on a side, and the grid expands with a multiplication factor of 1.15 applied to the spacing in both the east/west (column) and the north/south (row) directions. The total number of rows and columns that make up the PT model is 129 (that is, 64 nodes extend to the east, west, north and south of the central node). PW1 is located in row 65 , column 65 , at the center of the model grid. The model is constructed of eight layers with the Maquoketa Shale represented by layer two of the model. The lower six layers correspond to the units of the COAS. PW1 is simulated using the MODFLOW Multi-Node Well (MNW2) package (Konikow and others, 2009). This package allows the well to span multiple layers and distributes discharge from individual layers based on their relative transmissivities. Additional details of the development and calibration of the PT model are presented in appendix 3.

\section{Kettle Moraine Springs (KMS) Model}

Available water supply from the Silurian aquifer was estimated using the KMS model, created as a local inset of the regional LMB model (fig. 7). The KMS model domain, selected to achieve the optimization objectives, is much larger than the hatchery footprint, extending almost the height of Sheboygan County and into neighboring counties to the west and under Lake Michigan to the east (fig. 7). The north/south extent of the KMS model is $21.8 \mathrm{mi}$, and the east/west extent is $38.8 \mathrm{mi}$. Much of the input to the KMS model is inherited from the parent LMB regional model, including the aquifer units, the bedrock aquifer properties, and the configuration of the Lake Michigan regional sink.

The representation of surface water and springs at an appropriate scale is important so that the KMS model can appropriately simulate the shallow glacial and Silurian aquifer system. The refined grid in the KMS model (cells $250 \mathrm{ft}$ on a side) compared to the regional LMB model (cells 5,000 ft on a side) enables the KMS model to better assess the effects of different pumping scenarios on surface-water resources (details of model construction are provided in appendix 4).

The grid spacing for the KMS model is uniform, and the model consists of 460 rows and 820 columns. The initial aquifer properties, internal boundary conditions, geometry, and layering are inherited from the regional LMB model (Feinstein and others, 2010). However, in the KMSSFH area, these model inputs have been updated to take advantage of the finer grid discretization of the local inset model.

Three MODFLOW packages have been used to represent surface water in the KMS model domain. Within the area of interest — defined as approximately the area within a 5-mi 
radius from the center of the hatchery property - the Stream Flow Routing (SFR) package is used to represent local springs, Mink and Melius Creeks as well as other local streams. This package not only simulates groundwater/surface-water exchange but also routes water through the surface-water network and keeps track of the amount of surface water available (for example, to shallow pumping wells). Outside the area of interest, the River (RIV) package represents the exchange between the groundwater and stream (groundwater discharge to streams is called base flow). Everywhere in the KMS model domain, the Drain (DRN) package represents water bodies such as larger lakes and wetlands. This package simulates groundwater/surface-water exchange subject to the limitation that no water is exchanged once the water table falls below the altitude of the surface-water feature.

The hydraulic conductivity values of the glacial aquifer inherited from the LMB model were updated in the KMS model to better reflect the glacial depositional pattern at the finer grid scale of the inset model. Two sources of information were used to update the distribution of conductivity values: (1) the Wisconsin Geological and Natural History Survey (map of glacial units), and (2) the Wisconsin Department of Natural Resources (sediment descriptions from well completion reports). The steps taken to update glacial conductivity values are described in appendix 4 .

The Silurian aquifer is represented in the KMS model by only two hydraulic conductivity values: (1) to represent the upper $50 \mathrm{ft}$, assumed to be the weathered portion of the aquifer (horizontal hydraulic conductivity $=7.3 \mathrm{feet} / \mathrm{day}[\mathrm{ft} / \mathrm{d}]$ ), and (2) to represent the remaining thickness of the aquifer (horizontal hydraulic conductivity $=0.34 \mathrm{ft} / \mathrm{d}$ ). Additional details of the KMS model construction are described in appendix 4.

\section{Lake Michigan Basin (LMB) Modified Model}

The LMB modified model is simply the regional LMB model (Feinstein and others, 2010) with revised values of horizontal hydraulic conductivity and specific storage of the Cambrian-Ordovician units and overlying Maquoketa Shale. The LMB modified model inherits the boundary conditions, grid geometry, hydrologic stresses, and most aquifer properties present in the original LMB model (Feinstein and others, 2010). The revised horizontal hydraulic conductivity and specific storage values come from the calibration of the PT model to the pumping test and are applied in the LMB modified model within the area of influence of the pumping test. The area of influence was defined as the radial distance to the $0.01-\mathrm{ft}$ drawdown contour simulated by the calibrated PT model for the 3-day pumping test (about $5 \mathrm{mi}$ ). Additional details on the development of the LMB modified model are provided in appendix 5. Because the deep aquifer system is confined by the Maquoketa Shale, pumping from the COAS is not expected to affect surface-water features, so their representation in the LMB modified model remains at the coarse grid size of the LMB model (details provided in appendix 5).

\section{Estimation of Water Supply from the Silurian Aquifer}

The KMS model cells within the hatchery area are shown in figure 8. Each cell represents a location at which pumping from a Silurian aquifer well could be simulated. A general consideration for locating candidate wells is that the greater the distance between wells, the less the pumping from each will interfere with the other. This is important because residences within and nearby the KMSSFH boundary have private wells completed in the Silurian aquifer that could be affected by pumping at the hatchery. This, along with individual site considerations (topography, proximity to surface water, infrastructure requirements), resulted in the WDNR Fisheries Management Program prioritizing six candidate locations to be considered in pumping scenarios: (1) TOP1, (2) TOP2, (3) TOP3, (4) ALT1, (5) ALT2, and (6) ALT3 (fig. 8).

\section{Steps in Estimating Water Supply from the Silurian Aquifer}

The water supply for the KMSSFH that is available from the Silurian aquifer was estimated using the MODFLOW Groundwater Management Process (GWM) with the KMS model. That is, GWM was used to help identify well locations and pumping rates that maximized water supply from the shallow aquifer system to the hatchery operations subject to constraints on water levels, drawdown, and changes in groundwater discharge to surface-water features. These constraints were selected in consultation with staff of the WDNR Fisheries Management and Groundwater Sections. These constraints are measured relative to a model run, named "BaseCase," which has no pumping from candidate well locations. The GWM version incorporating MODFLOW-2005 (GWM-2005) was applied to a confined aquifer form of the KMS model (details in appendix 4) because of advantages gained in the linear programming algorithms when the response to pumping is linear (Grava, 2014; Grava and others, 2015). Pumping from the Silurian aquifer was optimized - using GWM-2005 and the confined aquifer version of the model - subject to head and flux constraints for three scenarios with different active constraints named "AllConstraints," "Constraints2," and "Constraints3." Each management formulation consists of a set of decision variables, an objective function, and a set of constraints. An update of the code allows consideration of water-level constraints inside the pumping well using the MODFLOW MNW package (Ahlfeld and Barlow, 2013).

Whereas GWM-2005 is valuable for testing optimization scenarios, the linearized model (confined aquifer form) potentially underestimates the effect of pumping on head and flux constraints; accordingly, the GWM-2005 simulations were used as a preliminary step to guide subsequent trial-and-error optimization with the full unconfined KMS model. Pumping rates similar to the optimized GWM-2005 rates were used 
with the full unconfined model and checked against the head and flux constraints. Pumping rates were adjusted to ensure that all the constraints were still honored.

For the AllContraints simulation, the KMS model used GWM-2005 to test the six candidate locations with simulated production wells that fully penetrate the Silurian aquifer (KMS model layers 4 and 5, see appendix 4) to identify three locations at which pumping from the Silurian aquifer can be maximized while meeting these constraints:

- Drawdown constraints:

- At 12 private wells - simulated drawdown is limited to less than 10 percent of depth from land surface to bottom of layer 4 , which is $50 \mathrm{ft}$ below top of the Silurian aquifer (an exception is that no drawdown constraint is applied to the well at the hatchery residence);

- At production wells at six candidate locations - the simulated stressed head inside the borehole must be at least $5 \mathrm{ft}$ above the bottom of the weathered Silurian aquifer (model layer 4).

- Flow reduction constraints:

- Melius Creek constraint (STRMCON_21) at the confluence of the north and south branches-baseflow reduction at the associated MODFLOW SFR reach is no more than 14 percent of the unstressed base flow;

- Spring constraint (PONDne) just northeast of property - discharge reduction at the single MODFLOW DRN cell is no more than 14 percent of the unstressed discharge (calculated in terms of head change that produces 14 percent reduction in flow);

- Hatchery springs constraint (STRMCON_11) - springflow reduction at the MODFLOW SFR reach associated with the springs currently supplying the hatchery is no more than 14 percent of the unstressed flow.

The Constraints 2 simulation tested the same six candidate locations as the AllConstraints simulation; however, for this simulation the constraint for the springs supplying the hatchery (STRMCON_11) was set to be inactive. The Constraints3 simulation tested the same six candidate locations as the AllConstraints simulation; however, for this simulation both the Melius Creek confluence constraint (STRMCON_21) and the constraint for springs currently supplying the hatchery (STRMCON_11) were set to be inactive.

\section{Estimated Water Supply from the Silurian Aquifer}

Following the use of GWM-2005 simulations to test optimization scenarios, estimates of water supply from the Silurian aquifer were finalized using trial-and-error optimization with the full unconfined KMS model. The finalized scenarios are discussed below.

The AllConstraints simulation resulted in a combined pumpage of $430 \mathrm{gal} / \mathrm{min}$ from three wells selected by GWM20015-TOP2, TOP3, and ALT2 (fig. 8). The drawdown and flow constraints that determined the selection of the three wells and their allowable pumping rates are listed in table 1. The constraint of the hatchery springs (STRMCON_11) was shown to be the primary limiting constraint. The reduction in flow from the springs was close to the limit of 14 percent. Other constraints limiting the selection of wells and the pumping rate were, in declining influence, the spring pond on the northern hatchery boundary (PONDne) and two private wells (SI084 and 99WELL8). The drawdown in the Silurian aquifer resulting from pumping of the AllConstraints simulation is presented in figure 9.

The Constraints 2 simulation tested the same six candidate locations as the AllConstraints simulation with one change to the set of constraints - the constraint for the springs supplying the hatchery (STRMCON_11) was set to be inactive; therefore, this simulation was not limited by a reduction in flow at the springs. This simulation resulted in a total pumpage of $480 \mathrm{gal} / \mathrm{min}$ from the three wells selected by GWM-20015TOP1, TOP3, and ALT2 (fig. 8). The drawdown and flow constraints that determined the three wells that were selected and the allowable pumping rates are listed in table 1 . The constraint of the Melius Creek confluence (STRMCON_21) was shown as the primary limiting constraint at almost a 14-percent reduction in flow. Other constraints limiting the selection of wells and the pumping rate were, in declining influence, the spring pond on the northern hatchery boundary (PONDne) and two private wells (99WELL8 and SI084). In the Constraints2 simulation, the simulated reduction in flow from the springs currently supplying the hatchery (STRMCON_11) was about 21 percent. Because this optimized scheme does not consider springflow as a constraint, it allowed pumping near the springs (well location TOP1) with a corresponding large effect on their discharge. The drawdown in the Silurian aquifer resulting from pumping of the Constraints 2 simulation is presented in figure 10. 


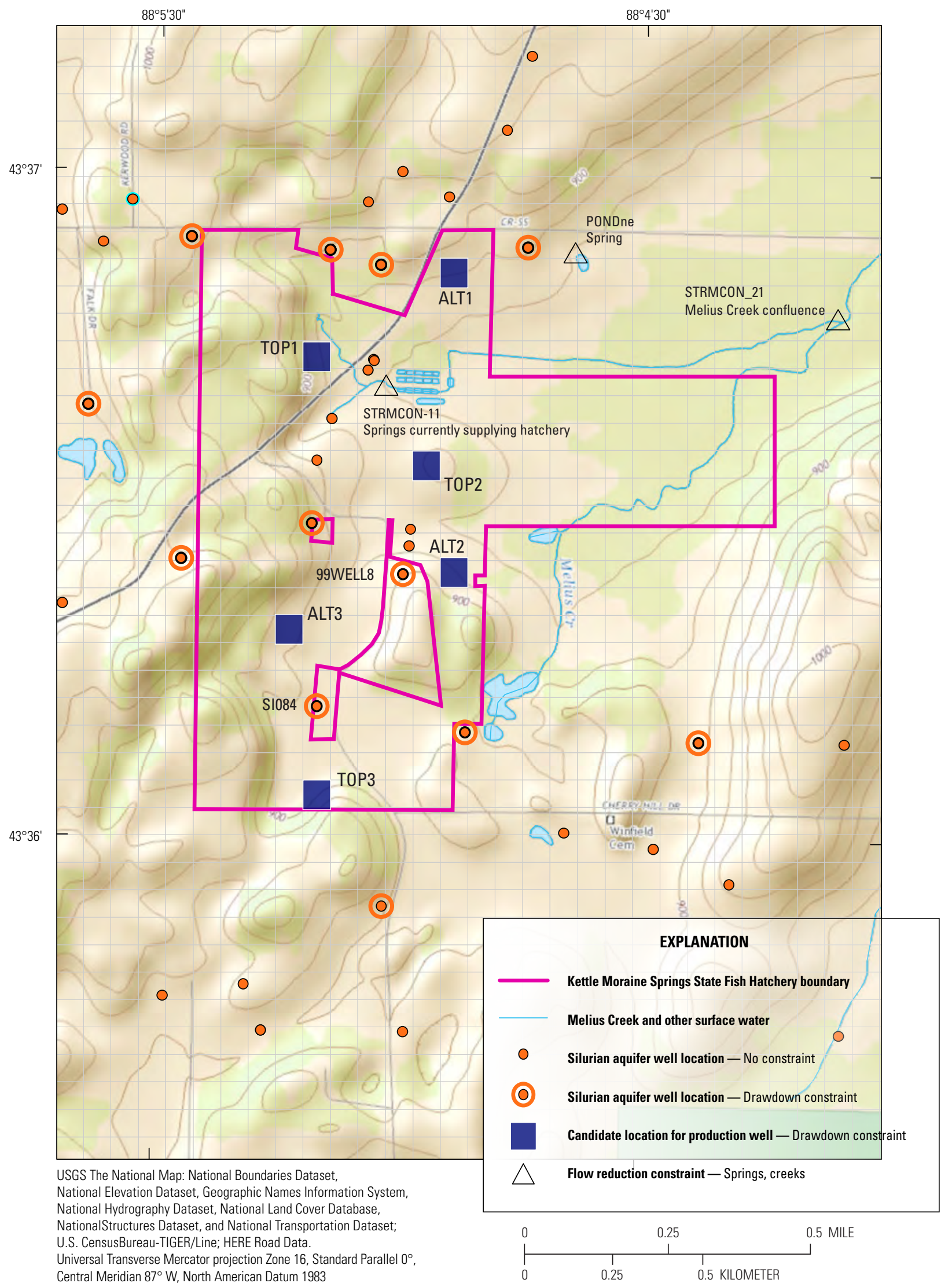

Figure 8. The Kettle Moraine Springs State Fish Hatchery showing the grid of the Kettle Moraine Springs model (KMS model), the six candidate locations for pumping from the Silurian aquifer, and the locations of drawdown and flow constraints to limit that pumping, Sheboygan County, Wisconsin. 
Table 1. Pumping scenarios for the Silurian aquifer and the three most productive wells selected from six candidate well locations considering different constraints and listed in declining influence.

[gal/min, gallons per minute; STRMCON_11, hatchery spring; PONDne, spring pond on hatchery boundary; SI084 and 99WELL8, private wells; STRMCON_21, constraint of Melius Creek confluence]

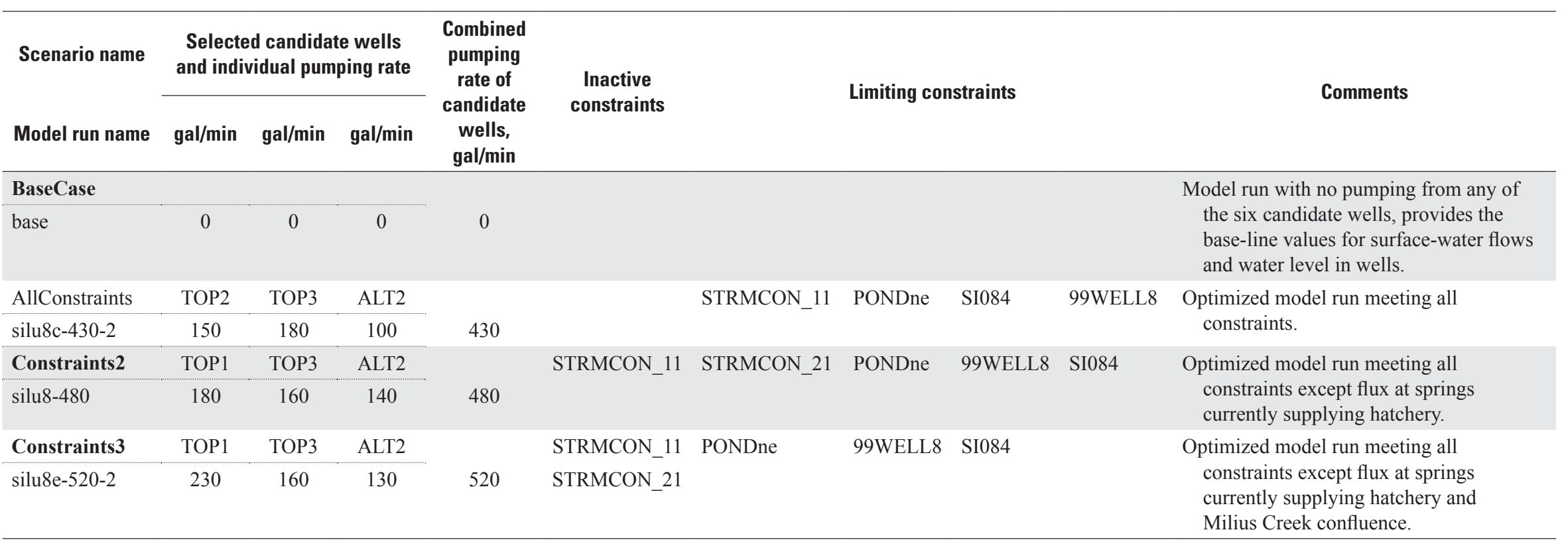




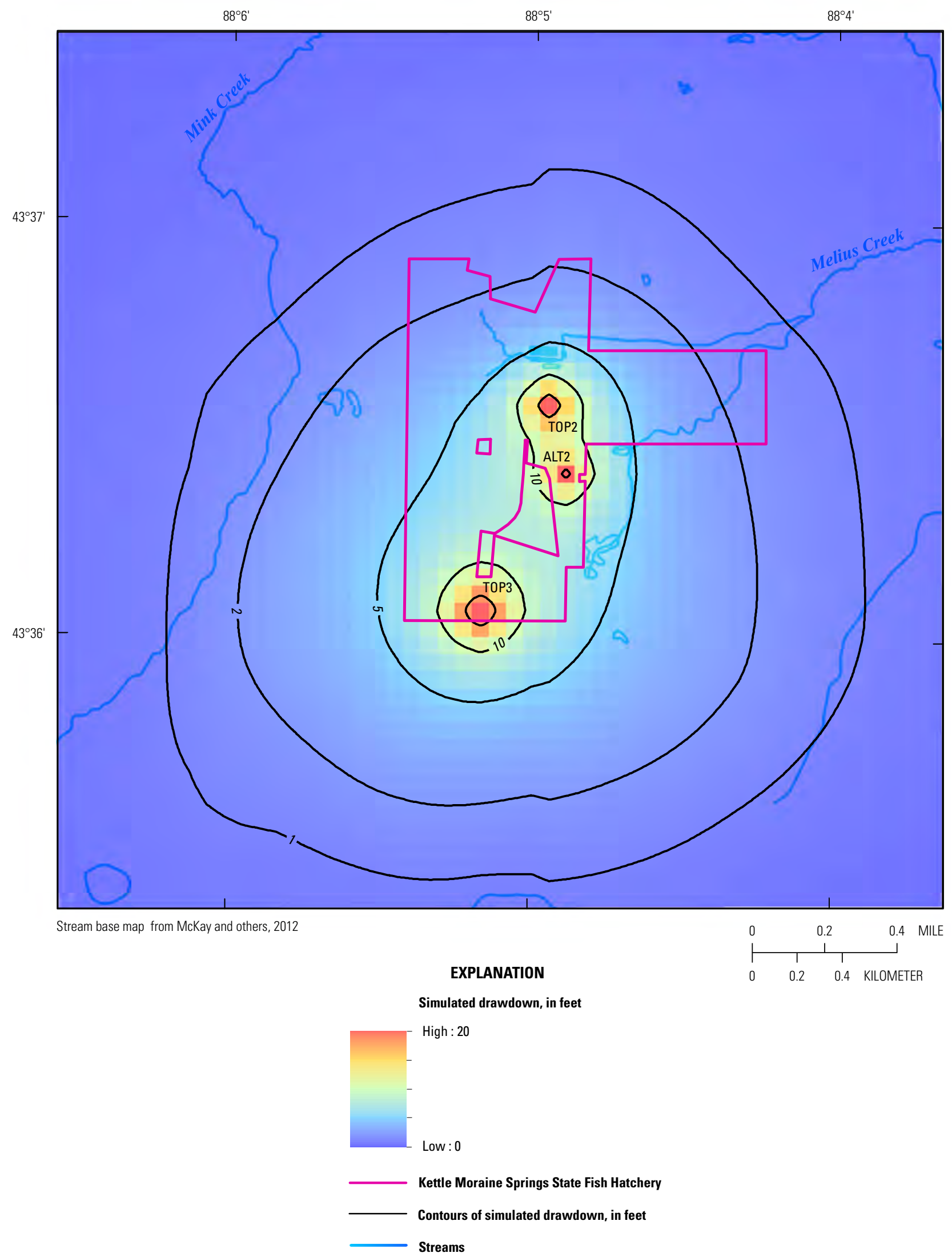

Figure 9. Drawdown in the Silurian aquifer under the AllConstraints simulation of pumping from wells TOP2, TOP3, and ALT2 at a combined rate of 430 gallons per minute, Sheboygan County, Wisconsin. 


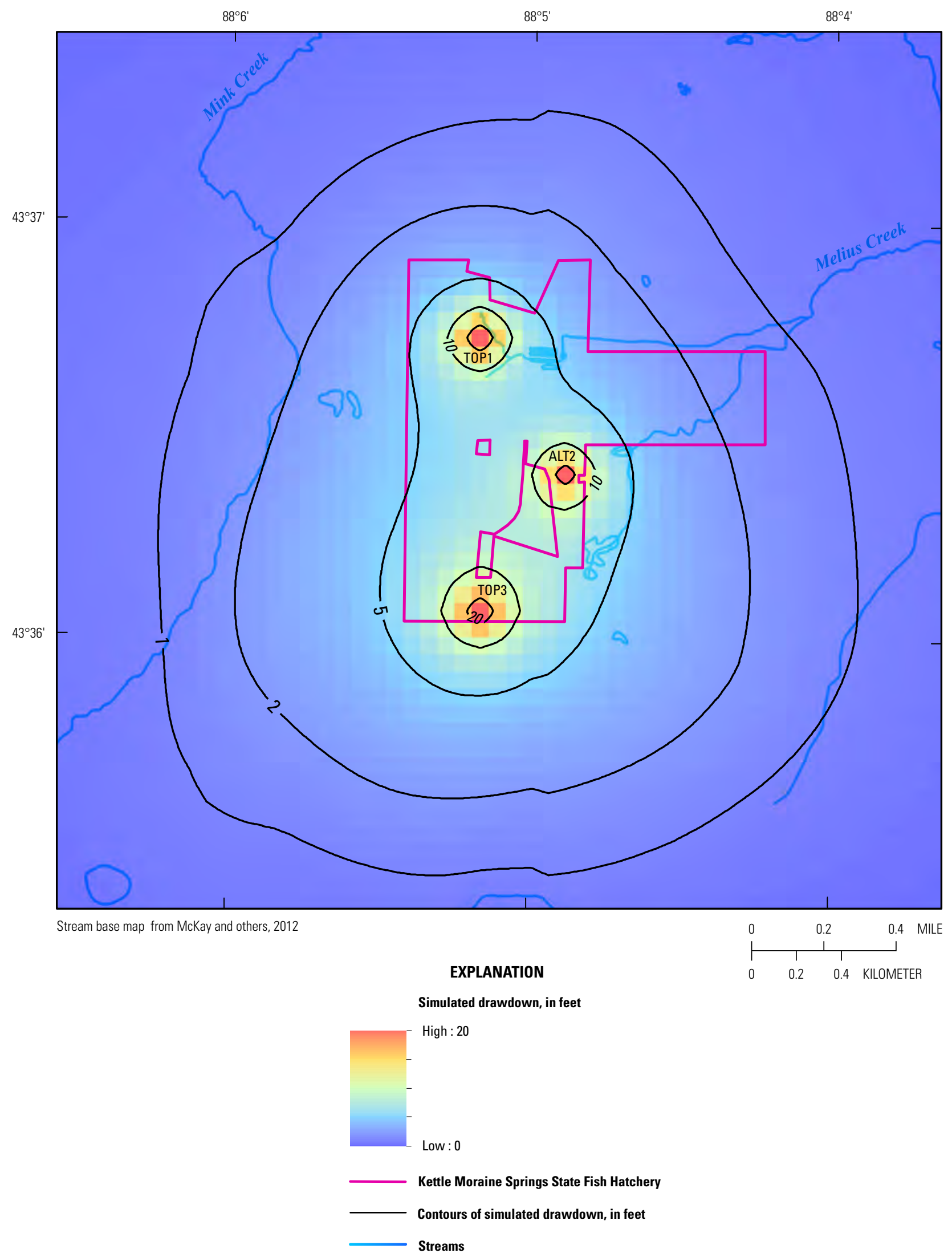

Figure 10. Drawdown in the Silurian aquifer under the Contraints2 simulation of pumping from wells TOP1, TOP3, and ALT2 at a combined rate of 480 gallons per minute, Sheboygan County, Wisconsin. 
The Constraints 3 simulation resulted in a total pumpage of $520 \mathrm{gal} / \mathrm{min}$ from the three selected wells. This simulation tested the same six candidate locations as the AllConstraints simulation; however, both the Melius Creek confluence constraint (STRMCON_21) and the constraint for springs currently supplying the hatchery (STRMCON_11) were set to be inactive. The selected locations, the same as for the Constraints2 simulation, were TOP1, TOP3, and ALT2 (fig. 8). The drawdown constraints that determined the selection of the three wells and the allowable pumping rates are listed in table 1 . The constraint of the nearby spring pond (PONDne) was shown to be the primary limiting constraint, followed in influence by two private wells (99WELL8 and SI084). In the Constraints 3 simulation, the reduction in flow from the springs currently supplying the hatchery was about 25 percent, and the reduction in flow at the confluence of Melius Creek was about 16 percent. The reductions are high because neither of these flow constraints was active in determining the optimized pumping scheme. The drawdown in the Silurian aquifer resulting from pumping of the Constraints 3 simulation is presented in figure 11.

This analysis, using the KMS model and the GWM, estimates the Silurian aquifer groundwater resource available to the KMSSFH and ranges from 430 to $520 \mathrm{gal} / \mathrm{min}$ and is provided by three wells. Of the six candidate locations across the hatchery grounds, the locations selected by the KMS model simulations were consistently TOP 3 and ALT2, plus either the TOP1 or TOP2 depending on which flow constraints were active (table 1).

\section{Estimation of Water Supply from the Cambrian-Ordovician Aquifer System}

Two groundwater-flow models were used in the assessment of water supply from the COAS for the KMSSFH: (1) the available water supply from the COAS was estimated using the PT model that had been developed to calibrate aquifer properties to observations of the aquifer pumping test. Inherent in the scenario analyses for hatchery water supply is the prediction of drawdown in and around two or three simulated wells on hatchery property pumping from the COAS; and (2) the LMB modified model was used to evaluate the regional impact of the estimated rates of pumping from this confined aquifer, expressed as drawdown at the closest known well completed in the COAS. The PT model domain relative to the LMB modified model domain is shown in figure 7.

\section{Pumping Test (PT) Model-Estimated Water Supply from the Cambrian-Ordovician Aquifer System}

The $97 / 8$-inch borehole drilled as a test production well for the aquifer pumping test (PW1) is now a supply well for the KMSSFH. The PT model was used for two simulations: (1) Scenario 1 is a simulation of the local effect of specified pumping from PW1 and one additional COAS production well (PW2); and (2) Scenario 2 is a simulation with specified pumping from PW1 and two additional COAS production wells (PW2 and PW3) (fig. 12). Because the COAS is well confined by the Maquoketa Shale, the placement of PW2 and PW3 relative to the existing PW1 is based solely on site considerations and maximizing the distance between wells. For both Scenarios 1 and 2, the allowable drawdown for each pumping well was set at $465 \mathrm{ft}$ to ensure that the pumping water level remained at least $100 \mathrm{ft}$ above the Sinnipee Group, which is the highest Cambrian-Ordovician unit open in each well. Pumping from the COAS was expected to have no effect on wells in the Silurian aquifer or on springs or surface water features (PT model layer 1), so these shallow features were not used as constraints on pumping scenarios.

The two simulations that were tested with the PT model follow projected seasonal water requirements through the life cycle of hatchery fish stock. Scenario 1 presents cycled pumping from PW1 and PW2. For 8 consecutive months of a year, each well pumps $300 \mathrm{gal} / \mathrm{min}$ (total of $600 \mathrm{gal} / \mathrm{min}$ ), and for the subsequent 4 consecutive months, each well pumps $600 \mathrm{gal} / \mathrm{min}$ (total of 1,200 gal/ $\mathrm{min})$. The average rate over these 12 months is $800 \mathrm{gal} / \mathrm{min}$. Scenario 2 corresponds to cycled pumping from PW1, PW2, and PW3. For 8 consecutive months, each well pumps 200 $\mathrm{gal} / \mathrm{min}$ (total of $600 \mathrm{gal} / \mathrm{min}$ ), and for the subsequent 4 consecutive months, each well pumps $500 \mathrm{gal} / \mathrm{min}$ (total of $1,500 \mathrm{gal} / \mathrm{min}$ ). The average rate over these 12 months is $900 \mathrm{gal} / \mathrm{min}$.

The local effects of Scenario 1 were simulated using the PT model to show the expected drawdown in the COAS by pumping from PW1 and PW2, cycling over 20 years. Drawdown in the potentiometric surface is simulated to be greater than $200 \mathrm{ft}$ near the two pumping wells and a little more than $100 \mathrm{ft}$ at a distance of about a mile from the pumping centers (fig. 13). Within the pumping wells, the drawdown is shown to fluctuate between about 230 and 430 $\mathrm{ft}$ as the pumping rate is varied seasonally (fig. 14). 


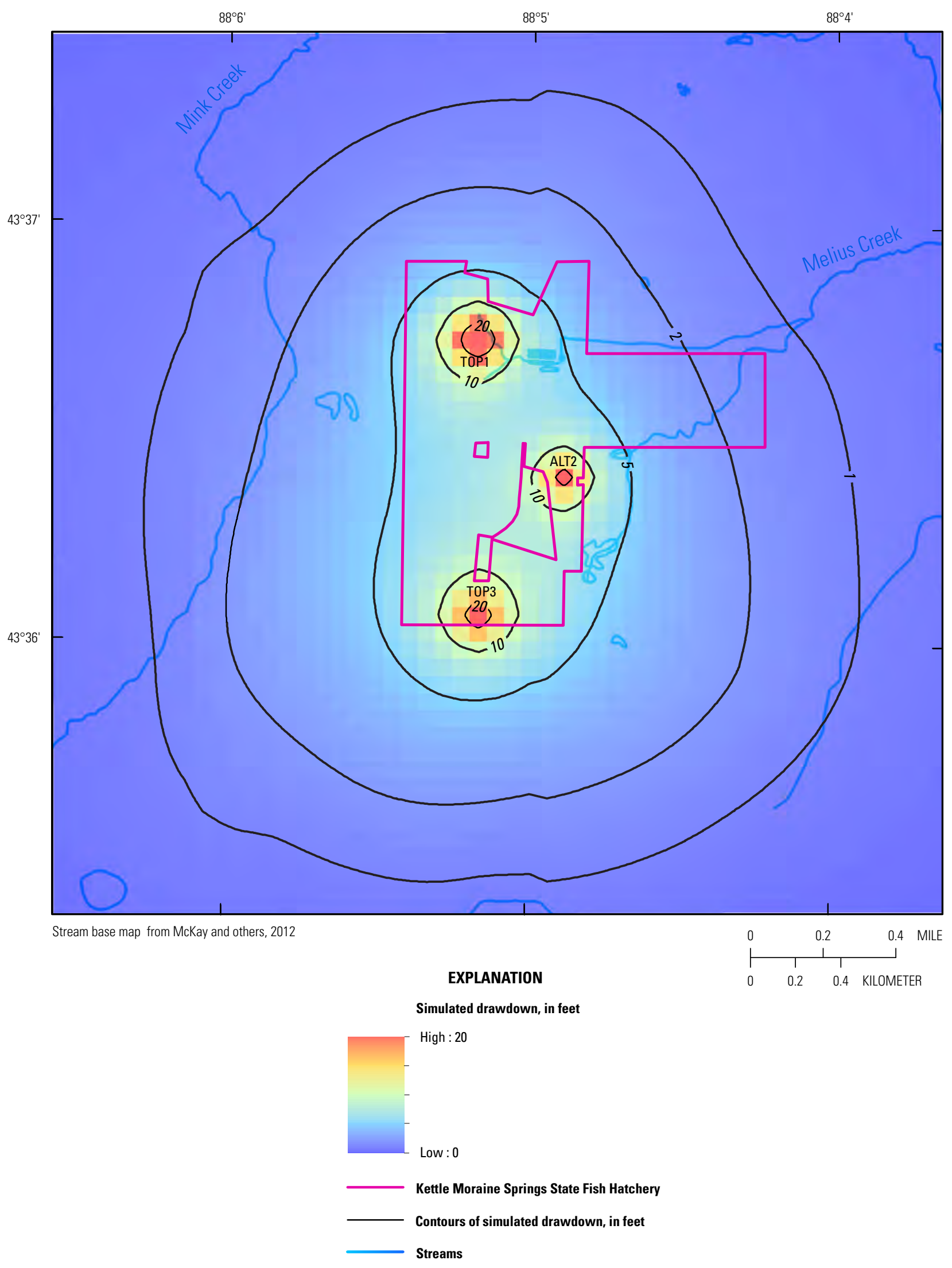

Figure 11. Drawdown in the Silurian aquifer under the Contraints3 simulation of pumping from wells TOP1, TOP3, and ALT2 at a combined rate of 520 gallons per minute, Sheboygan County, Wisconsin. 


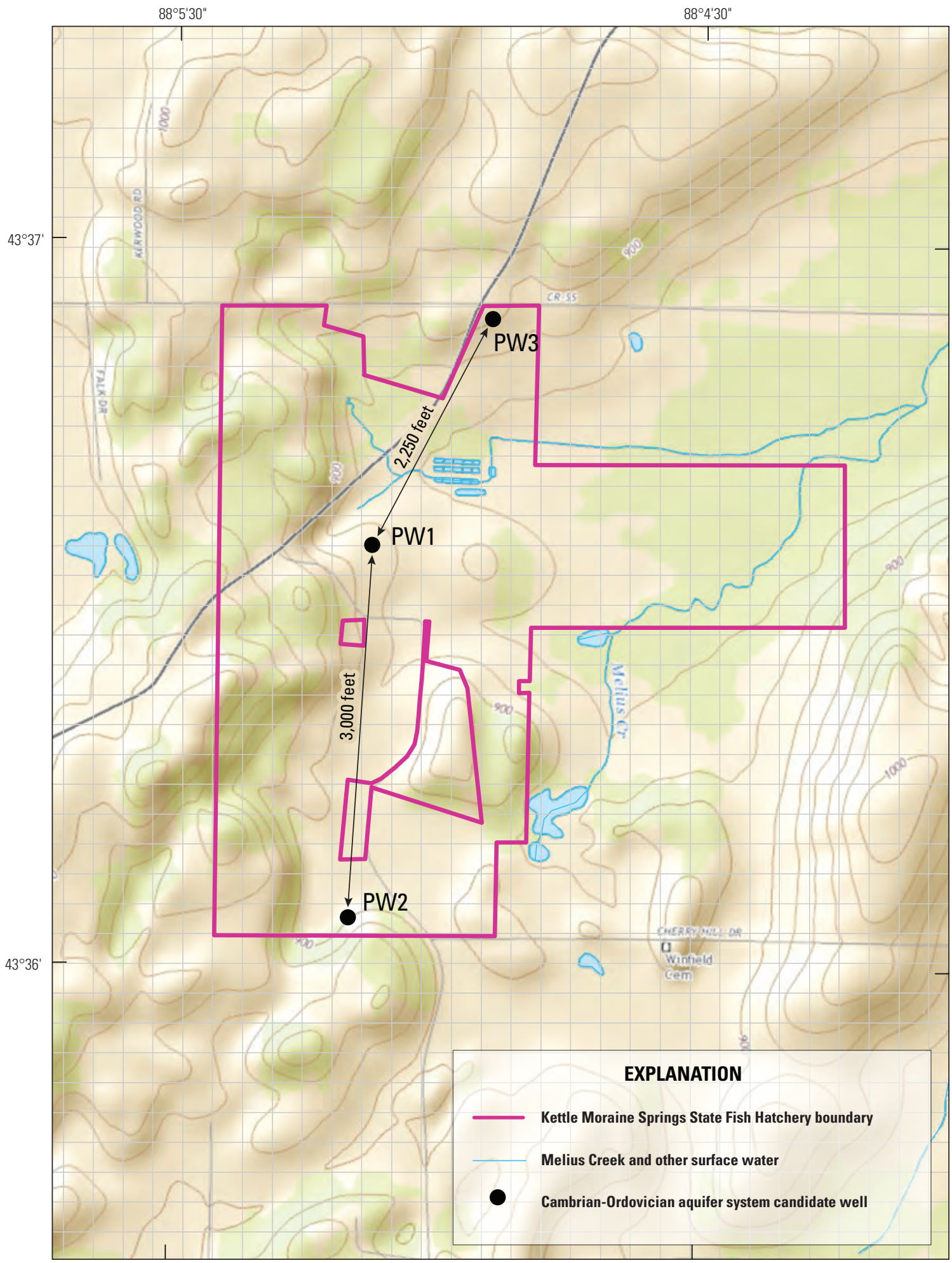

USGS The National Map: National Boundaries Dataset,

National Elevation Dataset, Geographic Names Information System,

National Hydrography Dataset, National Land Cover Database, National Structures

Dataset, and National Transportation Dataset; U.S. CensusBureau-TIGER/Line:

HERE Road Data.Universal Transverse Mercator projection Zone 16,

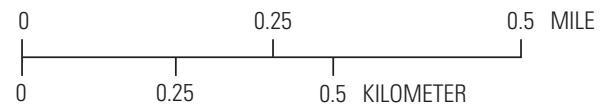

Standard Parallel $0^{\circ}$, Central Meridian 87 W, North American Datum 1983

Figure 12. The Kettle Moraine Springs State Fish Hatchery showing three candidate well locations for pumping from the Cambrian-Ordovician aquifer system, Sheboygan County, Wisconsin. 


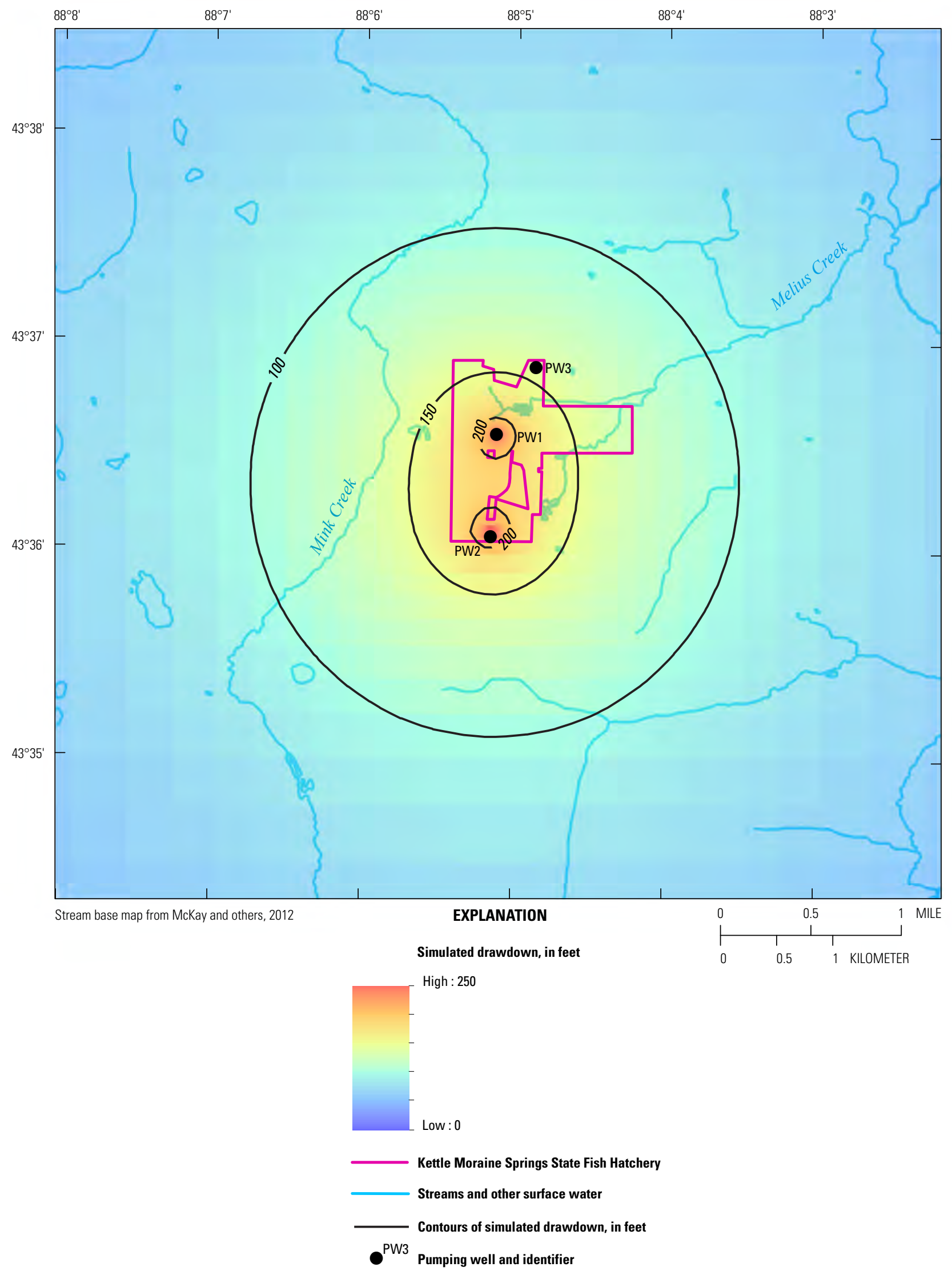

Figure 13. A portion of the Pumping Test model showing local drawdown in the Cambrian-Ordovician aquifer system after 20 years of pumping for Scenario 1 (two well cases), Sheboygan County, Wisconsin. 
Drawdown in PW1

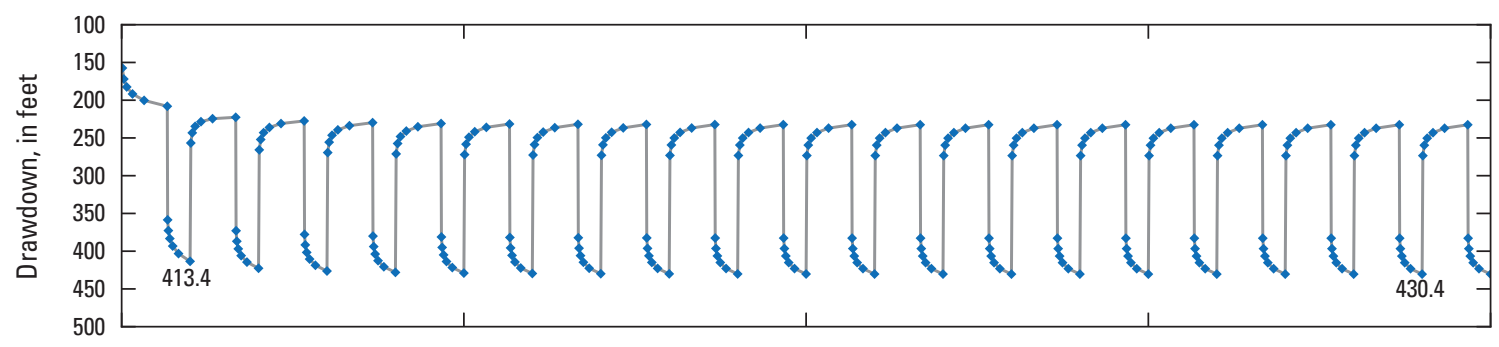

Drawdown in PW2

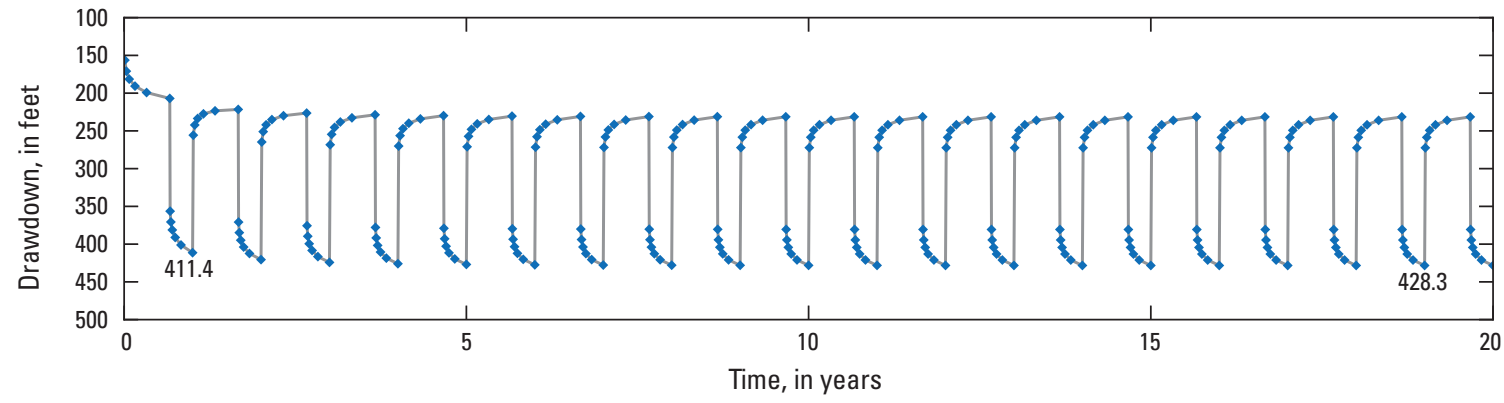

EXPLANATION

- Modeled water level

Figure 14. The drawdown in production wells PW1 and PW2 pumping on a seasonal schedule for 20 years of Scenario 1 (two well cases), Sheboygan County, Wisconsin.

The local effects of Scenario 2 were simulated using the PT model to show the expected drawdown in the COAS by pumping from PW1, PW2, and PW3, cycling over 20 years. Drawdown in the potentiometric surface is simulated to be about $250 \mathrm{ft}$ near the three pumping wells and about $125 \mathrm{ft}$ at a distance of a mile from the pumping centers (fig. 15). Within the pumping wells, the drawdown is shown to fluctuate between about 230 and $420 \mathrm{ft}$ (slight differences by well) as the pumping rate is varied seasonally (fig. 16).

\section{Lake Michigan Basin (LMB) Modified Model- Regional Effects of Pumping from the Cambrian- Ordovician Aquifer System}

The regional effects of water supply in Scenarios 1 and 2 are expressed as maps of simulated drawdown in eastern Wisconsin and as simulated drawdown at the location of the closest known well completed in the COAS - Campbellsport production well \#4 (fig. 17), Campbellsport, Wis., Scenario 1 has production wells PW1 and PW2 pumping at a combined average yearly rate of $800 \mathrm{gal} / \mathrm{min}$ for 20 years. The drawdown in the potentiometric surface, as expressed by the $5-\mathrm{ft}$ contour in figure 18, extends into neighboring counties and under Lake Michigan. The simulated drawdown in the COAS at the Campbellsport production well \#4 location is $16.9 \mathrm{ft}$ after 20 years, as represented by drawdown in the St. Peter Sandstone (fig. 19).

Scenario 2 has production wells PW1, PW2, and PW3 pumping at a combined average yearly rate of $900 \mathrm{gal} / \mathrm{min}$ for 20 years. Similar to Scenario 1, the drawdown in the potentiometric surface extends into neighboring counties and under Lake Michigan. Figure 20 shows that the regional effect of drawdown is slightly greater at the higher rates of Scenario 2 compared to Scenario 1. The simulated drawdown at the Campbellsport production well \#4 location is $19.0 \mathrm{ft}$ after 20 years, as represented by drawdown in the St. Peter Sandstone (fig. 21). 


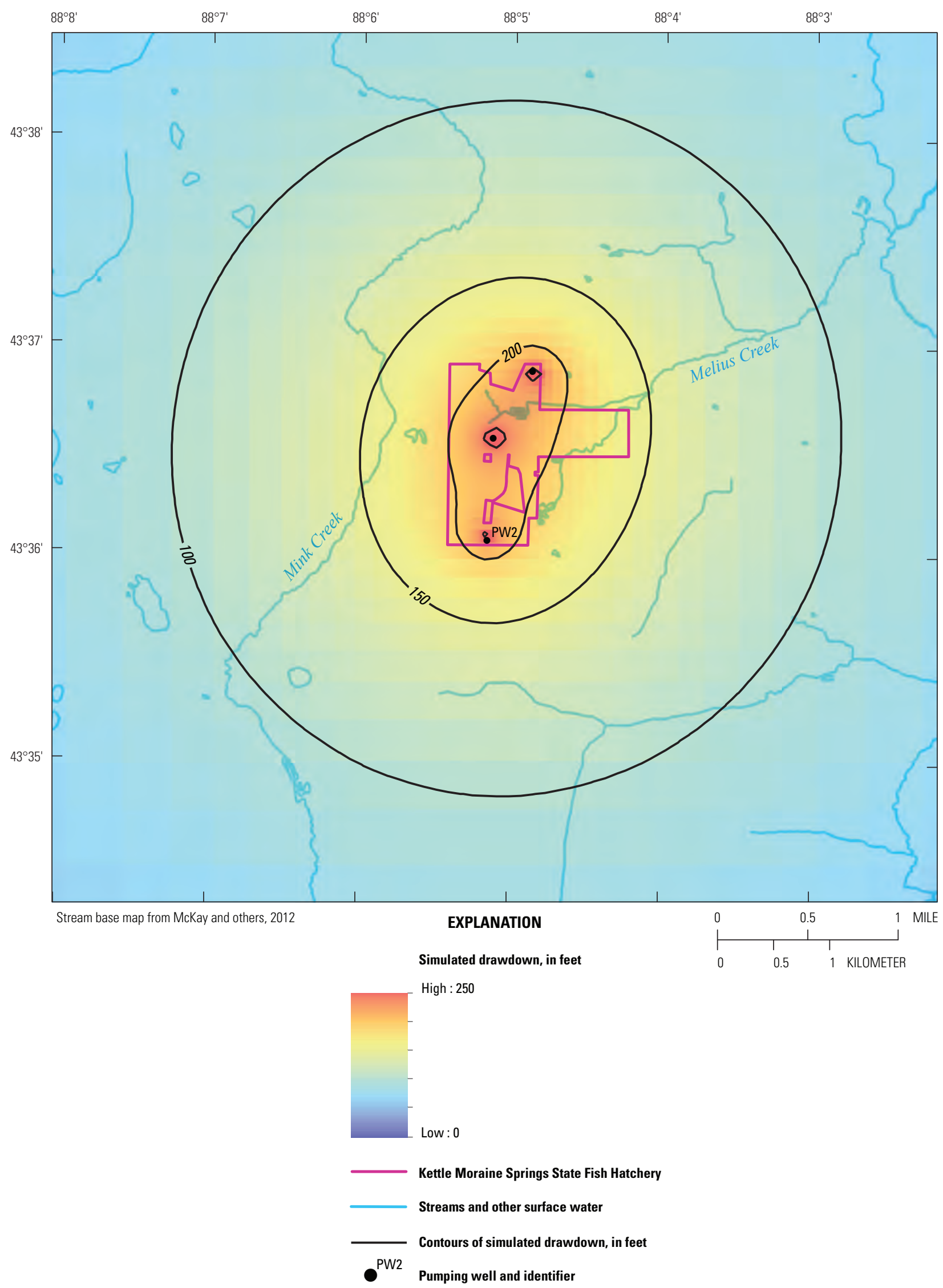

Figure 15. A portion of the Pumping Test model showing local drawdown in the Cambrian-Ordovician aquifer system after 20 years of pumping for Scenario 2 (three well cases), Sheboygan County, Wisconsin. 

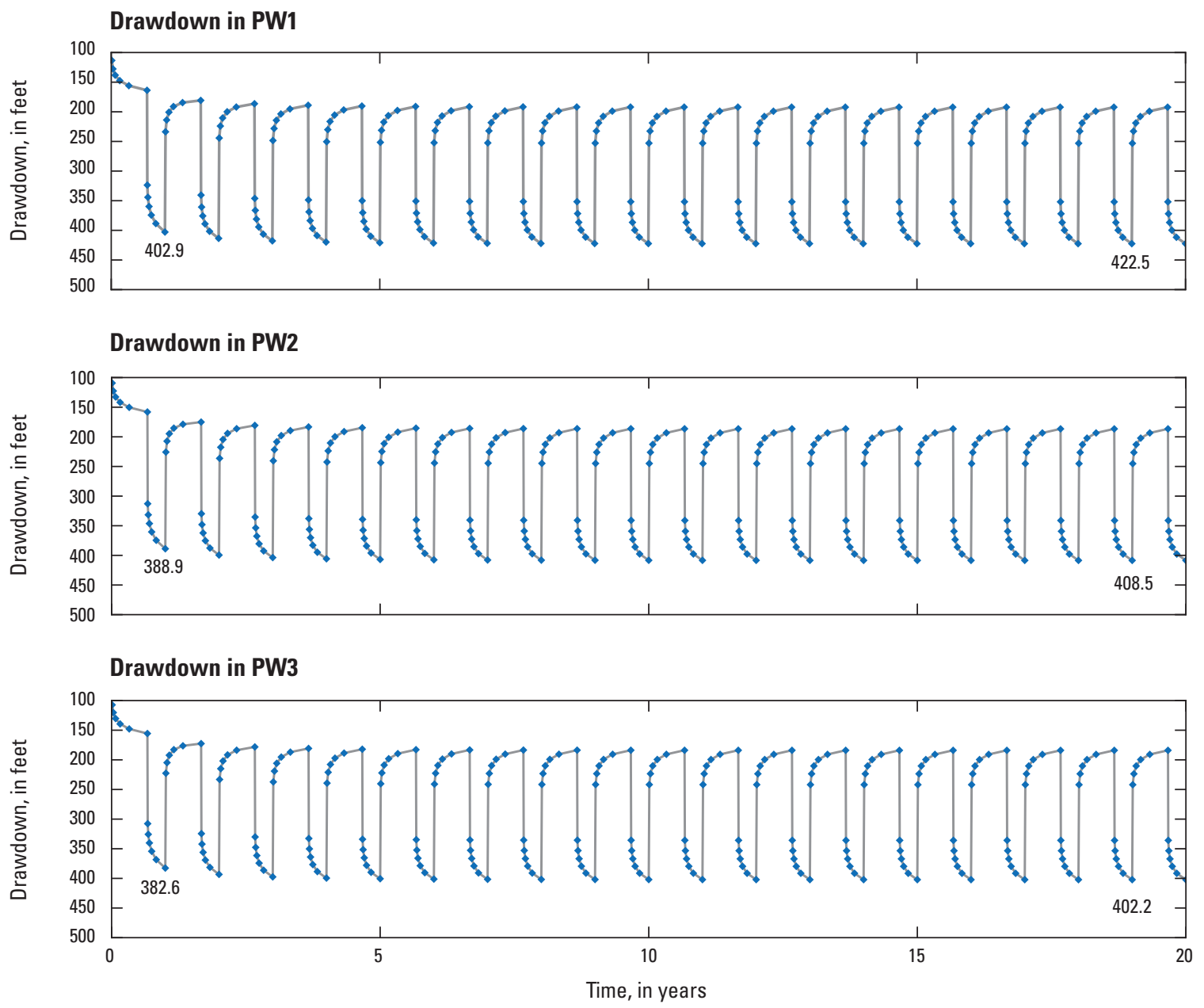

EXPLANATION

- Modeled water level

Figure 16. The drawdown in production wells PW1, PW2, and PW3 pumping on a seasonal schedule for 20 years of Scenario 2 (three well cases), Sheboygan County, Wisconsin. 


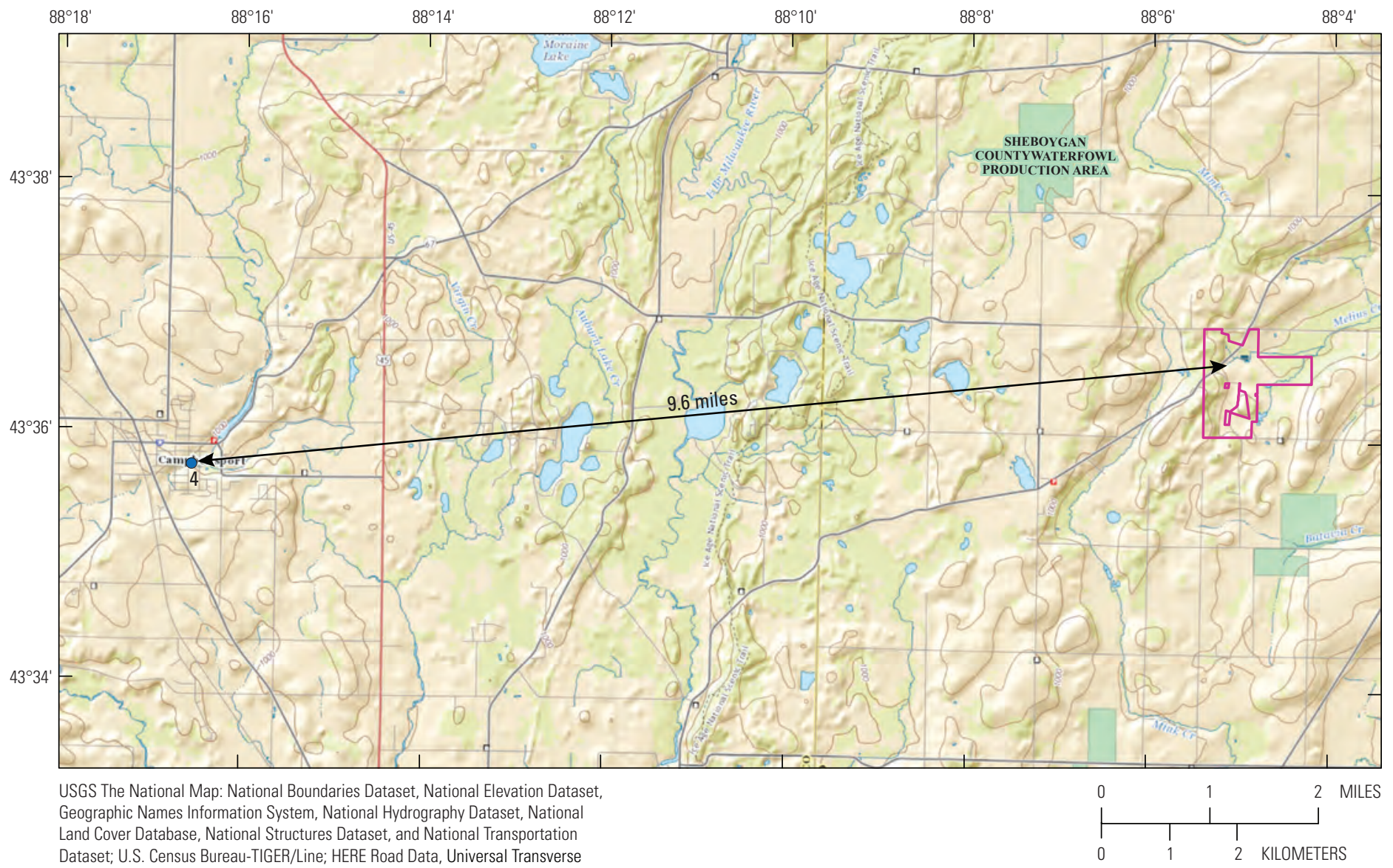

Mercator projection Zone 16, Standard Parallel $0^{\circ}$, Central Meridian $87^{\circ} \mathrm{W}$,

EXPLANATION

Kettle Moraine Springs State Fish Hatchery

$\bigcirc_{4}$ Campbellsport production well and identifier

Figure 17. Location of Campbellsport production well \#4, the closest known well pumping from the Cambrian-Ordovician aquifer system, Wisconsin. 


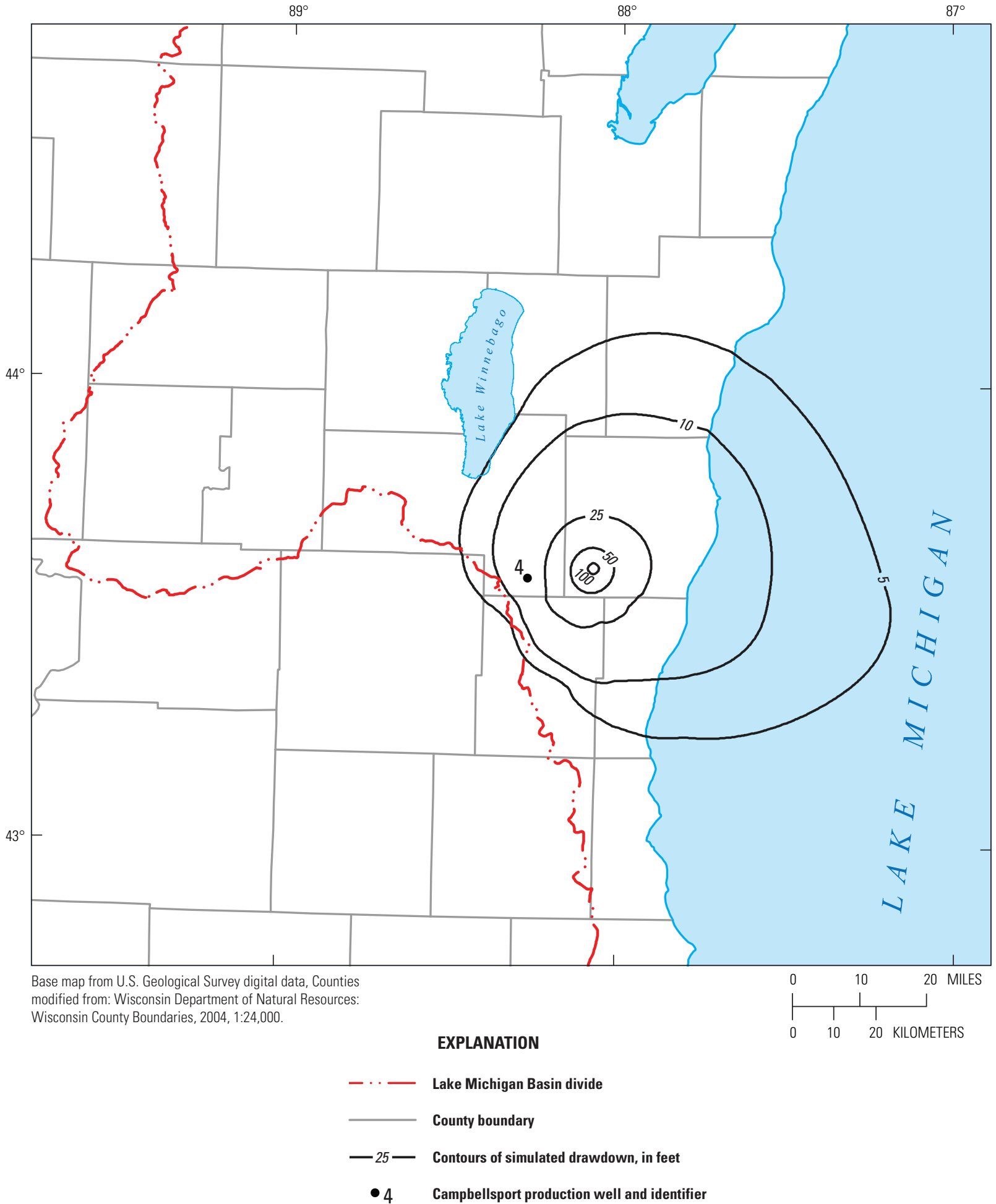

Figure 18. Simulated regional drawdown in the Cambrian-Ordovician aquifer system after 20 years of pumping for Scenario 1 (two well cases), Wisconsin. 


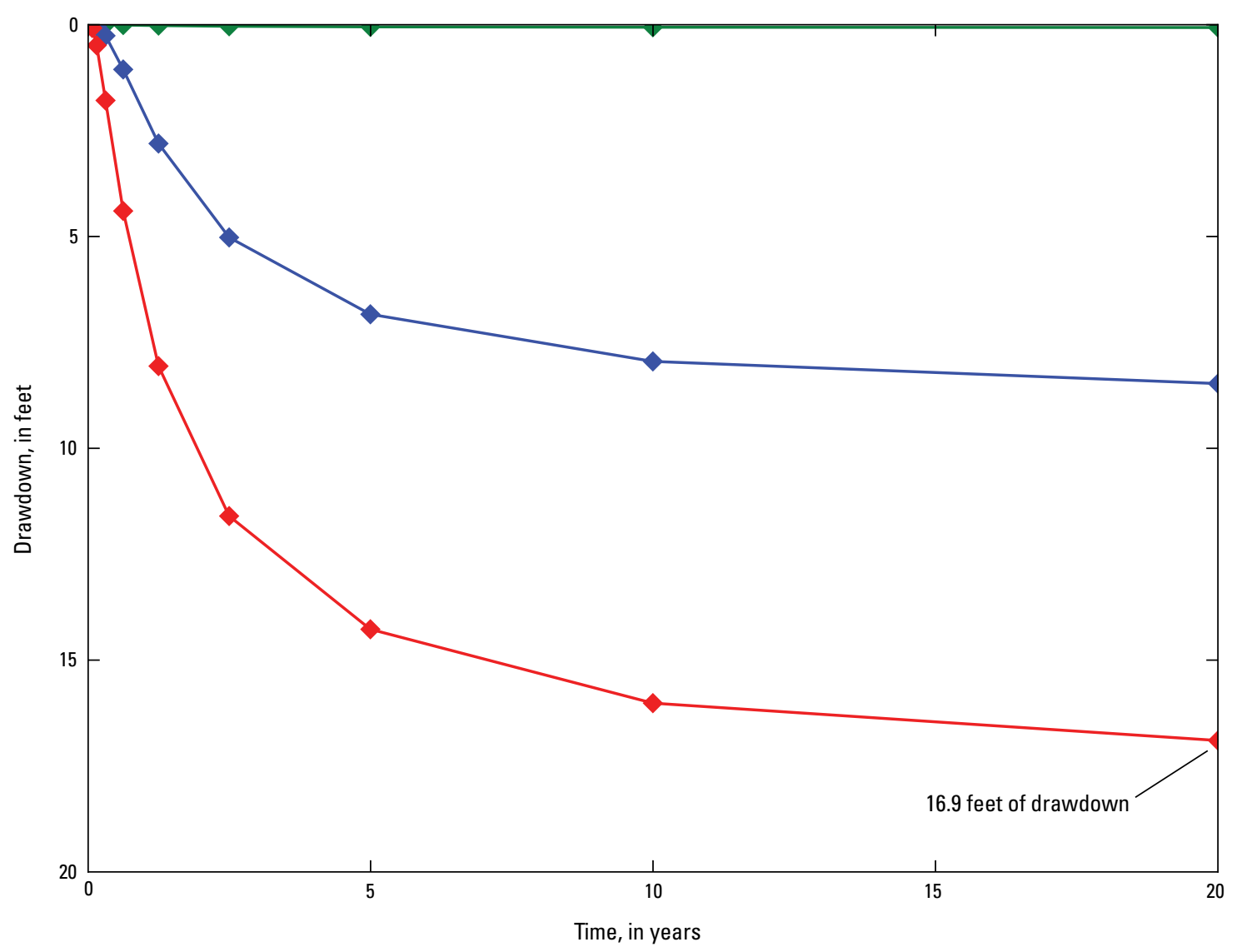

EXPLANATION

Silurian aquifer-Lake Michigan Basin modified model layer 12

- Maquoketa Shale confining unit — Lake Michigan Basin modified model layer 13

St. Peter sandstone aquifer — Lake Michigan Basin modified model layer 19

Figure 19. Simulated drawdown at Campbellsport production well \#4, 9.6 miles to the west of production well PW1, after 20 years of pumping for Scenario 1 (two well cases), Wisconsin. 


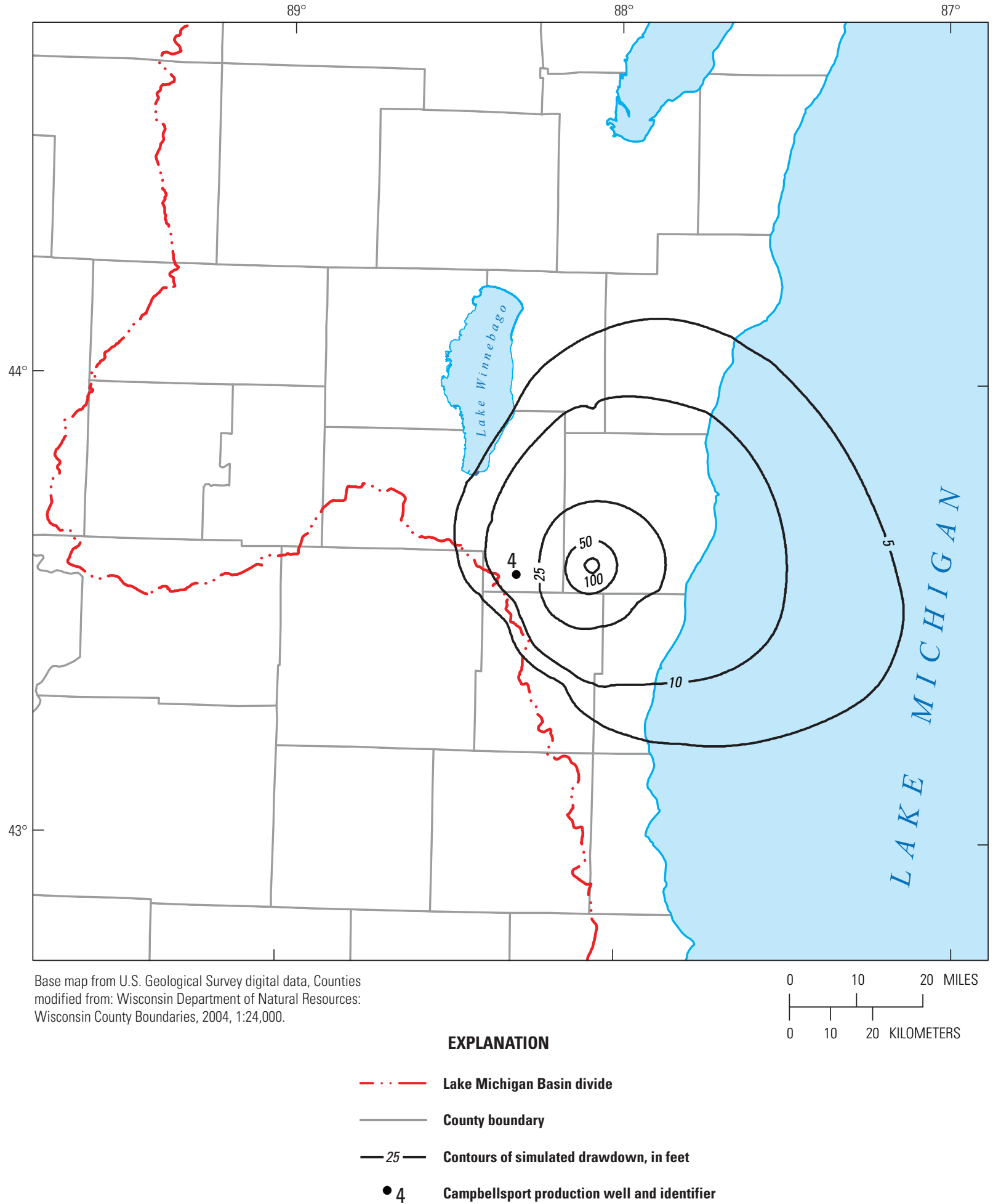

Figure 20. Simulated regional drawdown in the Cambrian-Ordovician aquifer system after 20 years of pumping for Scenario 2 (three well cases), Wisconsin. 


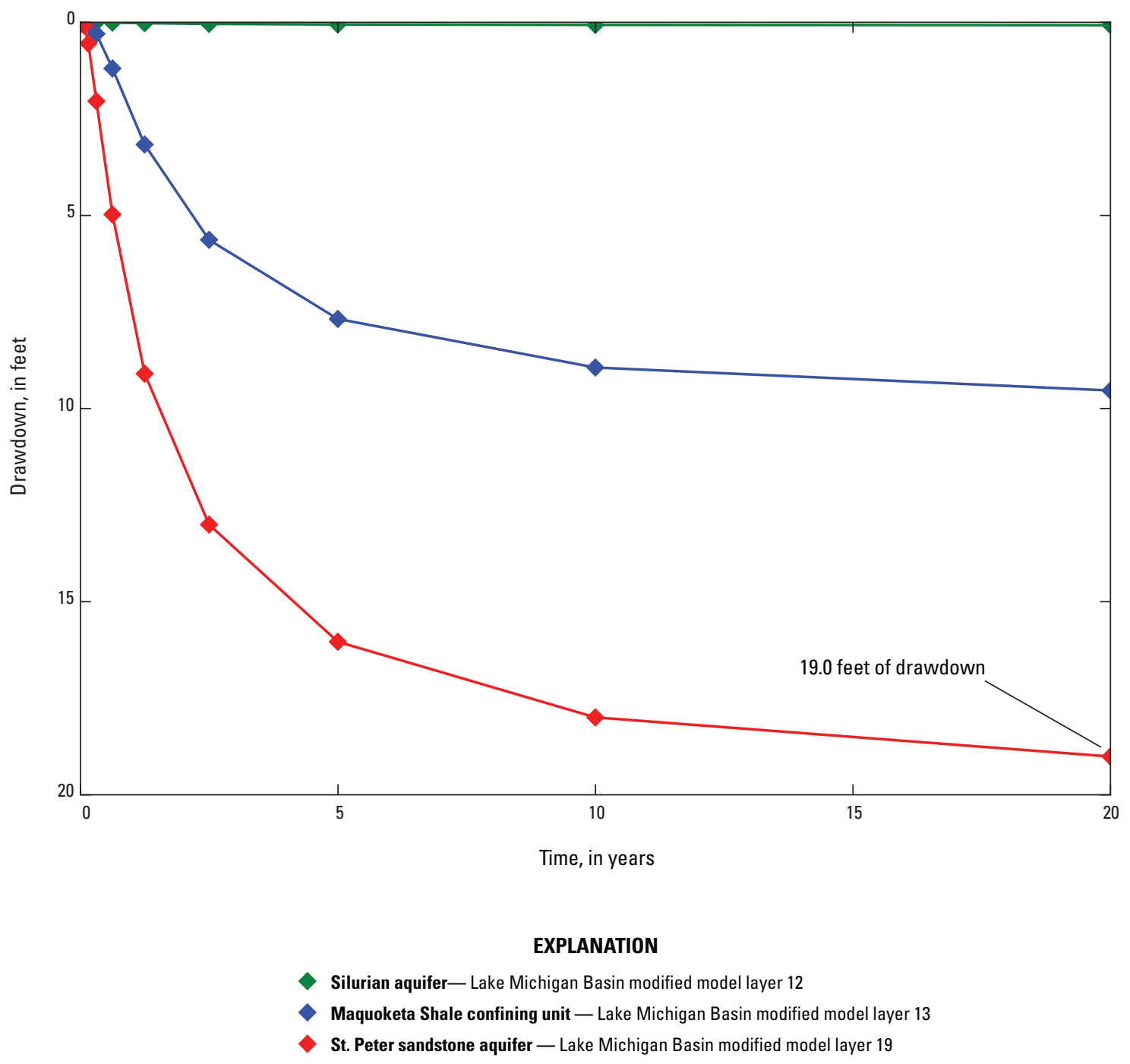

Figure 21. Simulated drawdown at Campbellsport production well \#4, 9.6 miles to the west of production well PW1, after 20 years of pumping for Scenario 1 (three well cases), Wisconsin. 


\section{Limitations of Analysis}

This study provided an estimate of the available water resources from bedrock aquifers at the KMSSFH. This assessment was based on historical data and information as well as data collected specifically for this study. Numerical models incorporate the data and information into a three-dimensional framework, enabling the simulation of groundwater flow from recharge to discharge. The models can evaluate the changes to flow systems under the stress of pumping, thereby determining the limits to the available water under selected scenarios. Recognized limitations of this analysis are found in a number of study elements discussed in this report.

\section{Model Limitations}

Models are an approximation of complex physical hydrogeology and hydrology. One aspect that limits the accuracy of the results is the discretization (horizontal and vertical spacing) of the grid at which heads and flows are solved, as well as the data density to support discretization. The grid spacing of the three models used in this study was scaled to the objectives of each model - large spacing $(5,000 \mathrm{ft}$ laterally) for the regional LMB modified model, fine spacing ( $250 \mathrm{ft}$ laterally) for the inset KMS model, and variable spacing for the PT model (extending from $4 \mathrm{ft}$ laterally at the location of the test well to $30,670 \mathrm{ft}$ at the edges of the domain). However, even the fine spacing of the KMS model might not be sufficient to reproduce the behavior of, for example, individual springs. More details on the grid spacing and the layering scheme for each model are provided in appendixes 3 and 5 .

Models representing unconfined conditions require different sets of boundary conditions than models representing only confined conditions. The KMS model and the LMB modified model each simulate unconfined conditions, and each model has a variety of external and internal boundary conditions designed to allow realistic representation of sources and sinks in the form of recharge distribution, interactions with surfacewater features (including streams, internal lakes, wetlands, and Lake Michigan), cross-boundary flows across the edges of the model domain, and pumping wells. The PT model is designed to simulate only the confined conditions of the COAS. Because the PT model domain is so large (almost $90 \mathrm{mi}$ on a side), its edge boundary conditions can be safely represented as no-flow boundaries in the north, east, and south directions away from the tested pumping well on the hatchery property at the center of the grid. To the west of the hatchery site, the confining Maquoketa Shale thins, and disappears, at a distance of about $23 \mathrm{mi}$ from the site, which allows water to move downward from the shallow aquifer system into the deep aquifer system. The potential for inflow from the west has no effect on the simulation of the step test and aquifer pumping test (see appendix 3) at the site. The two tests together lasted only 19 days, and therefore a no-flow condition to the west is acceptable to simulate the test and update the transmissivity and storativity of the deep aquifer system in the vicinity of the hatchery. However, when the PT model is used in prediction mode to simulate drawdown in the scenario pumping wells for over 20 years of pumping, then the western recharge boundary does come into play. A constant head boundary representing the area where the Maquoketa Shale thins was used to represent this source of water to the deep aquifer; however, because the area of inflow is uncertain, the boundary logically could have been set along the line where the Maquoketa disappears. Although the uncertainty about the location of leakage to the deep aquifer is a limitation in the application of the PT model (see appendix 3), it is also true that for the objectives of the modeling (that is, to determine if the simulated water level in the pumped boreholes is at least $100 \mathrm{ft}$ above the top of the COAS), it is in no way decisive. The more realistic (but more coarsely discretized) LMB modified model was used to simulate the regional effect of long-term pumping because it incorporates all the sources and sinks that influence water levels as the stress moves away from the pumping center.

The KMS model incorporates cell-by-cell variation to represent the heterogeneity of hydraulic conductivity in the glacial aquifer; however, the Silurian aquifer in the vicinity of the hatchery is represented by only two values: (1) to represent the upper $50 \mathrm{ft}$, assumed to be the weathered portion of the aquifer ( $7.3 \mathrm{ft} / \mathrm{d})$, and (2) to represent the remaining thickness of the aquifer $(0.34 \mathrm{ft} / \mathrm{d})$ (see appendix 4$)$. These calibrated values are sufficient to capture the overall capacity of the aquifer to transmit flow, but they do not reproduce the variability in the aquifer that might exist because of unweathered zones in the upper Silurian model layer or because of fracture or fossilized zones at depth; therefore, it is possible that a well installed in the Silurian bedrock can experience lower or higher transmissivity than that input to the model, and, as a result, experience more or less drawdown than predicted by the model.

The KMS model was only simulated under steady-state conditions designed to reproduce the average long-term behavior of the system. Seasonal or climatic forcing might affect some of the predicted effects of the selected pumping schemes. For example, it is possible that under drought conditions the reduction in the flow of Melius Creek will be greater than the 14-percent threshold adopted for optimization purposes.

\section{Project Limitations}

Project limitations involve lack of information about the groundwater system. They can be grouped by aquifer type.

\section{Glacial Aquifer}

Unlike the Silurian bedrock and COAS aquifers, the response to pumping of water levels in the glacial aquifer at the site has not been studied by means of a pumping test. The hydraulic conductivity assigned to the glacial layers in 
the KMS model is based mostly on an interpretation of the horizontal trends of the coarse faction in the till and outwash deposits derived from household well logs (appendix 4). If wells completed in the glacial aquifer were considered as water supply for the hatchery, it would be prudent to perform one or more pumping tests in order to reduce the uncertainty in the range of hydraulic conductivity assigned to these unconsolidated deposits in the model.

\section{Silurian Aquifer Chemistry}

The Silurian aquifer is known to have unpredictable water chemistry, with some locations and completion depths producing water with elevated iron and hydrogen sulfide. The presence and nature of fracturing of the Silurian dolomite bedrock may exhibit an influence on water quality that would require additional study to understand. The water resource estimated from this study is provided without consideration of the water quality of the water produced from the Silurian aquifer. Predicting the actual volumes of high quality water, or water of any particular quality, was beyond the scope of the study described in this report.

\section{Cambrian Ordovician Aquifer Pumping Test}

Two wells were constructed in the COAS for an aquifer pumping test: (1) the pumped test well (PW1) and (2) the monitoring well (MW) for measuring the aquifer response to the pumping stress. The physical pumping test and data collection effort were considered to have been very successful. The calibration effort was able to closely reproduce the water levels observed continually in the monitoring well through the step test and the full test (appendix 2). These results strongly support the results and conclusions of the report; however, this interpretation relied on the single point at which aquifer response was measured. Additional monitoring points at varying distances and directions from the pumping test would have provided additional data to confirm and refine the interpretation of the aquifer properties measured under pumping stress and would have been ideal if the completed intervals of the PW1 and MW were the same. But the intervals are different because of conditions encountered during the drilling and completion of both wells. The analysis of the aquifer pumping test data accounts for the difference in completion interval through the use of the MNW2 package.

\section{Temperature and Salinity}

In areas of eastern Wisconsin, water produced from the COAS exhibits areas of elevated temperature and salinity (Ryling, 1961). Typically, it is the deeper formations that exhibit lower quality. Water produced during the aquifer pumping test conducted at the site did not show elevated levels of these parameters; however, it is possible that long-term pumping will induce water flow from outside the local area that does show elevated levels of temperature and salinity. For any long-term pumping system, it is important to monitor water quality in case it is subject to change.

\section{Possible Future Work}

The constraints that guided the optimization of the pumping schemes for the Silurian aquifer might require updating in the future if conditions change or if new information arises. For example, if new household wells just outside the hatchery property were to be installed, then the optimization exercise might need to be repeated with the KMS model. Similarly, if a deep well completed in the COAS were to come online in close proximity to the hatchery (closer than the Campbellsport \#4 well located $9.6 \mathrm{mi}$ west of the site), then it might be necessary to revisit the regional flow analysis with the LMB modified model to determine the mutual interference of the deep hatchery wells with the offsite well. If the hatchery water supply was in need of expansion beyond the rates anticipated in this study, then it might be necessary to test the capacity of the glacial aquifer directly by means of one or more pumping tests in order to update the KMS model before simulating a multi-aquifer water supply system featuring the interconnected glacial and Silurian aquifers. If seasonal or long-term water-level fluctuation in the unconfined aquifers was to become a concern, new scenarios with the KMS model would be needed. If water quality becomes a concern, sampling and new simulations would be needed to estimate the availability of water meeting specific water-quality constraints.

\section{Summary and Conclusions}

Three groundwater-flow models were used to evaluate regional groundwater flow and to estimate the water resources available to the Kettle Moraine Springs State Fish Hatchery (KMSSFH) from bedrock aquifers under selected scenarios of well placement, seasonal water requirements, and constraints on impact to local springs, creeks, and household wells. An analysis of three scenarios estimated that the Silurian aquifer could supply the KMSSFH with 430-520 gallons per minute $(\mathrm{gal} / \mathrm{min})$ of water from wells at three locations on the hatchery grounds. Two locations were consistently identified by the analysis as being able to produce the largest amount of water while still meeting the flow and water-level constraints; the third location varied between two choices depending on constraints applied. An analysis of two scenarios estimated that the Cambrian-Ordovician aquifer system could supply the KMSSFH with $800 \mathrm{gal} / \mathrm{min}$ (two wells) to $900 \mathrm{gal} / \mathrm{min}$ of water (three wells). These two scenarios were constrained by drawdown in pumping wells and the seasonal variations in pumping that were considered to match projected water requirements through the life cycle of hatchery fish stock. 


\section{References Cited}

Ahlfeld, D.P., and Barlow, P.M., 2013, Use of multi-node wells in the Groundwater-Management Process of MODFLOW-2005 (GWM-2005): U.S. Geological Survey Techniques and Methods, book 6, chap. A47, 26 p. (Also available at, https://pubs.usgs.gov/tm/06/a47/.)

Carlson, A.E., Principato, S.M., Chapel, D.M., and Mickelson, D.M., 2011, Quaternary geology of Sheboygan County, Wisconsin: Wisconsin Geological and Natural History Survey Bulletin 106, 32 p., 2 pls.

Conlon, T.D., 1995, Hydrogeology of southwestern Sheboygan County, Wisconsin, in the vicinity of the Kettle Moraine Springs fish hatchery: U.S. Geological Survey Water-Resources Investigations Report 94-4106, 17 p.

Feinstein, D.T., Hunt, R.J., and Reeves, H.W., 2010, Regional groundwater-flow model of the Lake Michigan Basin in support of Great Lakes Basin water availability and use studies: U.S. Geological Survey Scientific Investigations Report 2010-5109, 379 p.

Grava, A., 2014, Use of a ground water flow model to optimize expansion of the water supply well system at an eastern Wisconsin fish hatchery: University of MilanoBicocca Master's Thesis, $82 \mathrm{p}$.

Grava, A., Feinstein, D.T., Barlow, P.M., Bonomi, T., Buarne', F., Dunning, C.P., and Hunt, R.J., 2015, Optimization techniques using MODFLOW-GWM. MODFLOW and More 2015 conference: Golden, Colorado, Colorado School of Mines, May 31-June 4, 2015. Conference proceedings paper, p. 354-358.

Haserodt, M.J., Feinstein, D.T., Dunning, C.P., Buchwald, C.A, and Hunt, R.J., 2017, GWM-2005 and MODFLOW-NWT groundwater flow models of the bedrock aquifers at the Kettle Moraine Springs State Fish Hatchery, Sheboygan County, Wisconsin: U.S. Geological Survey data release, https://doi.org/10.5066/F77S7KW2.

Kammerer, P.A., 1998, Geology, ground-water flow, and dissolved-solids concentrations in ground water along hydrogeologic sections through Wisconsin aquifers: U.S. Geological Survey Hydrologic Atlas 731, 4 plates. [Also available at, https://pubs.er.usgs.gov/publication/ ha731.]

Konikow, L.F., Hornberger, G.Z., Halford, K.J., and Hanson, R.T., 2009, Revised multi-node well (MNW2) package for MODFLOW ground-water flow model: U.S. Geological Survey Techniques and Methods book 6, chap. A30, 67 p.
Langevin, C.D., Thorne, D.T., Jr., Dausman, A.M., Sukop, M.C., and Guo, Weixing, 2007, SEAWAT Version 4-A computer program for simulation of multi-species solute and heat transport: U.S. Geological Survey Techniques and Methods, book 6, chap. A22, 39 p.

Luczaj, J.A. 2013, Geology of the Niagara Escarpment in Wisconsin: Wisconsin Geological and Natural History Survey, v. 22, part 1. (Also available at, https://wgnhs.uwex. edu/pubs/gs22a01/.)

Martin, L., 1916, The physical geography of Wisconsin: State of Wisconsin, University of Wisconsin Press, 30 p., ISBN 978-0-299-03475-7.

McKay, L., Bondelid, T., Dewald, T., Johnston, J., Moore, R., and Rea, A., 2012, National Hydrography Dataset Plus, Version 2: User guide: U.S. Environmental Protection Agency, accessed November 3, 2015, at https://www.epa.gov/waterdata/nhdplus-national-hydrography-dataset-plus.

Niswonger, R.G., Panday, Sorab, and Ibaraki, M Motomu, 2011, MODFLOW-NWT, A Newton formulation for MODFLOW-2005: U.S. Geological Survey Techniques and Methods 6-A37, $44 \mathrm{p}$.

Ryling, R.W., 1961, A preliminary study of the distribution of saline water in the bedrock aquifers of eastern Wisconsin: Wisconsin Geological and Natural History Survey Information Circular 5, $23 \mathrm{p}$.

Wilson, J.T., 2012, Water-quality assessment of the Cambrian-Ordovician aquifer system in the northern Midwest, United States: U.S. Geological Survey Scientific Investigations Report 2011-5229, 154 p.

Wisconsin Department of Natural Resources, 2010, Comprehensive study of Wisconsin's fish propagation system: Consultant report prepared by HDR, Inc.

Wisconsin Department of Natural Resources, 2014, Wisconsin fishing facts, accessed June 6, 2016, at, http://dnr.wi.gov/news/weekly/article/?id=2929.

Wisconsin Geological and Natural History Survey, 2011, Bedrock stratigraphic units in Wisconsin: Wisconsin Geological and Natural History Survey Educational Series 51, 4 p. 



\section{Appendix 1. Construction of a Test Production Well and a Monitoring Well in the Cambrian-Ordovician Aquifer System}

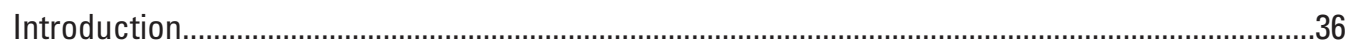

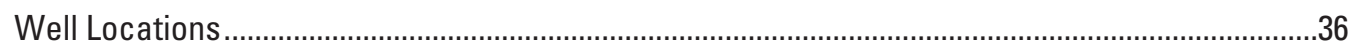

Well Drilling and Completion...................................................................................................36

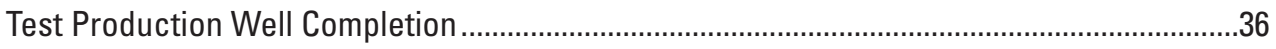

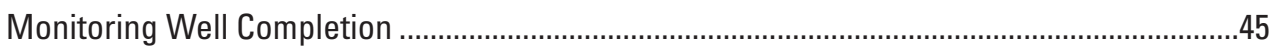

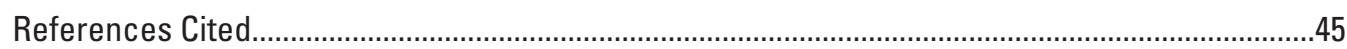

\section{Figures}

1-1. Map showing location of the test production well (PW1) and monitoring well (MW) completed in the Cambrian-Ordovician aquifer system at the Kettle Moraine Springs State Fish Hatchery, Sheboygan County, Wisconsin

1-2. Stratigraphic tops and completion intervals of the test production well (PW1) and the monitoring well (MW) at the Kettle Moraine Springs State Fish Hatchery, Sheboygan County, Wisconsin.

1-3. Geophysical logs of the monitoring well (MW) at the Kettle Moraine Springs State Fish Hatchery, Sheboygan County, Wisconsin.

\section{Tables}

1-1. Stratigraphic tops encountered during drilling of the test production well (PW1) and monitoring well (MW) at the Kettle Moraine Springs State

Fish Hatchery, Sheboygan County, Wisconsin.

1-2. Well construction data for the test production well (PW1) and monitoring well (MW) at the Kettle Moraine Springs State Fish Hatchery, Sheboygan County, Wisconsin. 


\section{Introduction}

This study used two groundwater-flow models to assess the amount of groundwater available from the CambrianOrdovician aquifer system (COAS) at the Kettle Moraine Springs State Fish Hatchery (KMSSFH). In any model, it is desirable that values of parameters representing an aquifer be based on local measurements to the extent possible. To this end, an aquifer pumping test provides useful physical data because it measures local aquifer characteristics under the stress of pumping. An aquifer pumping test is particularly valuable in this study because there are very few existing wells completed in the COAS in this area of Wisconsin from which to gain aquifer information.

Recognizing the value of conducting an aquifer pumping test for this groundwater resource assessment, the Wisconsin Department of Natural Resources (WDNR) contracted with the U.S. Geological Survey (USGS) Research Drilling Program based in Las Vegas, Nevada, to drill a test production well and a monitoring well on the property of the KMSSFH. This appendix presents information about the drilling, geophysical logging, and completion of these two wells. Appendix 2 presents information about the design and performance of the aquifer pumping test conducted as part of this study.

\section{Well Locations}

The location chosen for the test production well on KMSSFH property was influenced by the interest of the WDNR in having the well close to the existing hatchery facilities. With that in mind, the location chosen was at coordinates 43.609742 North, 88.085286 West (fig. 1-1). The USGS site identification (ID) of this well is $433635088050701 \mathrm{SB}-$ $13 / 20 \mathrm{E} / 10-3158$, and the well is named "PW1" in this report.

A well whose purpose is to monitor drawdown during an aquifer pumping test should be located at a distance such that a reasonably large volume of the aquifer is present between the point of pumping stress and the point of observation, but a monitoring well should not be so far away that the effect of the pumping stress is small over the period of the test and difficult to observe. Applying these considerations to the accessible drilling sites across the KMSSFH, the location of the monitoring well was selected to be 1,470 feet (ft) southeast of PW1 at 43.606606 North, 88.081842 West (fig. 1-1). The USGS site ID of this well is 433624088045502 SB-13/20E/10-3159, and the well is named "MW" in this report.

\section{Well Drilling and Completion}

The USGS Research Drilling Program crew was mobilized from Nevada on April 30, 2015, arriving at the KMSSFH on May 3. On May 4, drilling at the MW location began, and on May 13, the total depth of about 1,239 ft was reached (note that the well casing was only completed to $1,238 \mathrm{ft}$ depth and the well was only logged to $1,237 \mathrm{ft}$ depth). The different rock types and water zones encountered from surface to total depth necessitated using both air rotary and mud rotary drilling methods. By May 19, geophysical logs had been run and the MW well had been completed. On May 30, drilling at the PW1 location began, and on June 25, PW1 was completed at a total depth of $1,020 \mathrm{ft}$. The stratigraphic formation tops of the COAS units encountered during drilling of PW1 and MW are presented in table $1-1$ and figure 1-2. These stratigraphic tops were identified from considering the drilling penetration rate and behavior, the lithology of drill cuttings, and geophysical logging conducted on the monitoring well. The stratigraphic names used in this report conform to those established by the Wisconsin Geological and Natural History Survey (2011).

The monitoring well was logged with geophysical tools on May 13, 2015, by the Wisconsin Geological and Natural History Survey (UW-Extension) to provide profiles of:

- Gamma

- Caliper

- Single point resistivity

- Self-potential

- Normal resistivity

- Fluid temperature

- Fluid conductivity

The geophysical logs from the monitoring well are combined in a single borehole profile shown in figure 1-3. At the time of this report, PW1 had not been geophysically logged. Based solely on drilling information, the formation tops encountered in PW1 were found to be equivalent to those at MW, though consistently about $22 \mathrm{ft}$ higher in altitude in PW1. This observation is consistent with the generally easterly dip of bedrock in this part of Wisconsin.

\section{Test Production Well Completion}

The completion of the test production well, PW1, refers to its uncased, open interval. PW1 is completed in the COAS over a depth interval from 581 to $1,020 \mathrm{ft}$ below land surface (an altitude interval from about 303 to $-136 \mathrm{ft}$ relative to the North American Vertical Datum of 1988 [NAVD 88] datum). The open interval includes the bottom part of the Maquoketa Shale and all of the Sinnipee and Ancell Groups. The bottom of the well is projected to be at the contact between the Ancell Group and the underlying Prairie du Chien-Trempealeau Group. The well is completed as a $97 / 8$-inch diameter open hole. Well construction details are presented in table 1-2. 


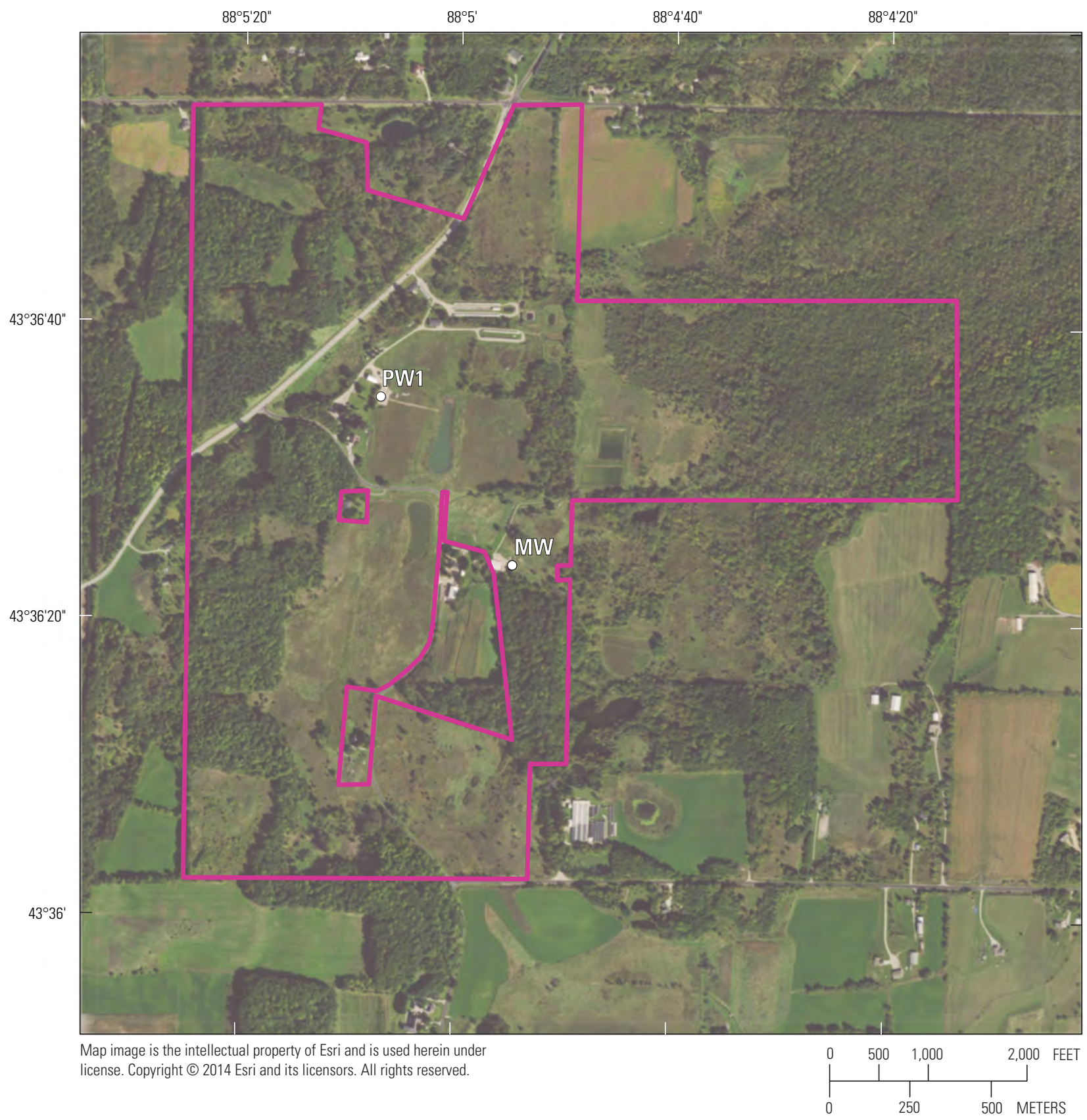

EXPLANATION

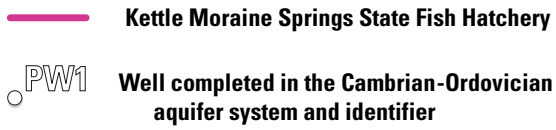
aquifer system and identifier

Figure 1-1. Location of the test production well (PW1) and monitoring well (MW) completed in the Cambrian-Ordovician aquifer system at the Kettle Moraine Springs State Fish Hatchery, Sheboygan County, Wisconsin. 
Table 1-1. Stratigraphic tops encountered during drilling of the test production well (PW1) and monitoring well (MW) at the Kettle Moraine Springs State Fish Hatchery, Sheboygan County, Wisconsin.

[datum, North American Vertical Datum of 1988 (NAVD 88); --, no data]

\begin{tabular}{lcccc}
\hline & \multicolumn{2}{c}{ PW1 - Test production well } & \multicolumn{2}{c}{ MW - Monitoring well } \\
\cline { 2 - 5 } & $\begin{array}{c}\text { Depth } \\
\text { (feet below } \\
\text { land surface) }\end{array}$ & $\begin{array}{c}\text { Altitude } \\
\text { (feet above } \\
\text { datum) }\end{array}$ & $\begin{array}{c}\text { Depth } \\
\text { (feet below } \\
\text { land surface) }\end{array}$ & $\begin{array}{c}\text { Altitude } \\
\text { (feet above } \\
\text { datum) }\end{array}$ \\
\hline Land surface & -- & 883.64 & -- & 881.98 \\
\hline Top of Maquoketa Shale & 408 & 475.64 & 428 & 453.98 \\
\hline Top of Sinnipee Group & 670 & 213.64 & 690 & 191.98 \\
\hline Top of Ancell Group & 807 & 76.64 & 827 & 54.98 \\
\hline Top of Prairie du Chien-Trempealeau Groups & 1,020 & -136.36 & 1,040 & -158.02 \\
\hline Top of Elk Mound Group & -- & -- & 1,145 & -263.02 \\
\hline Total Well Depth & 1,020 & -136.36 & 1,239 & -357.02 \\
\hline
\end{tabular}




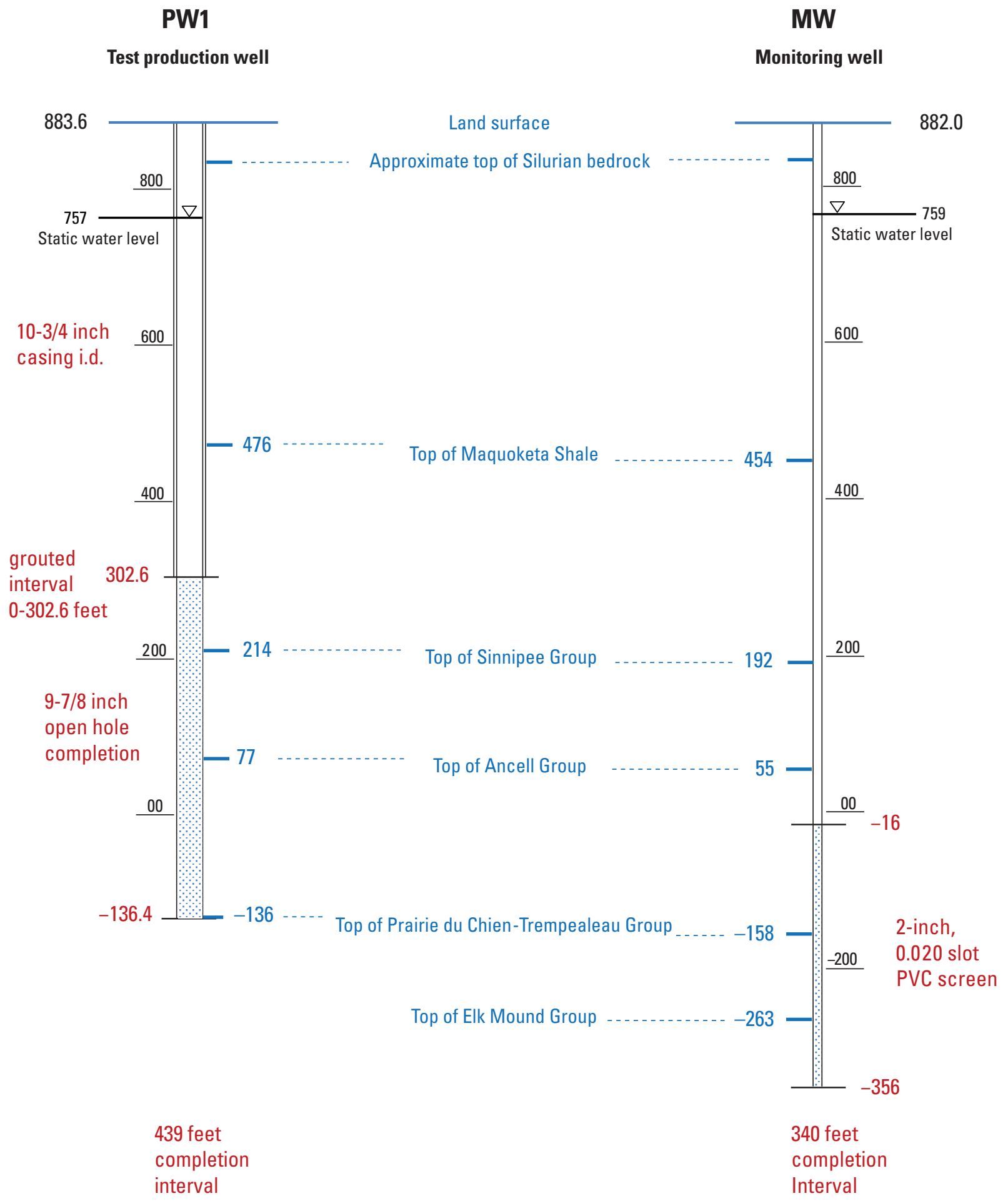

Figure 1-2. Stratigraphic tops and completion intervals of the test production well (PW1) and the monitoring well (MW) at the Kettle Moraine Springs State Fish Hatchery, Sheboygan County, Wisconsin. 


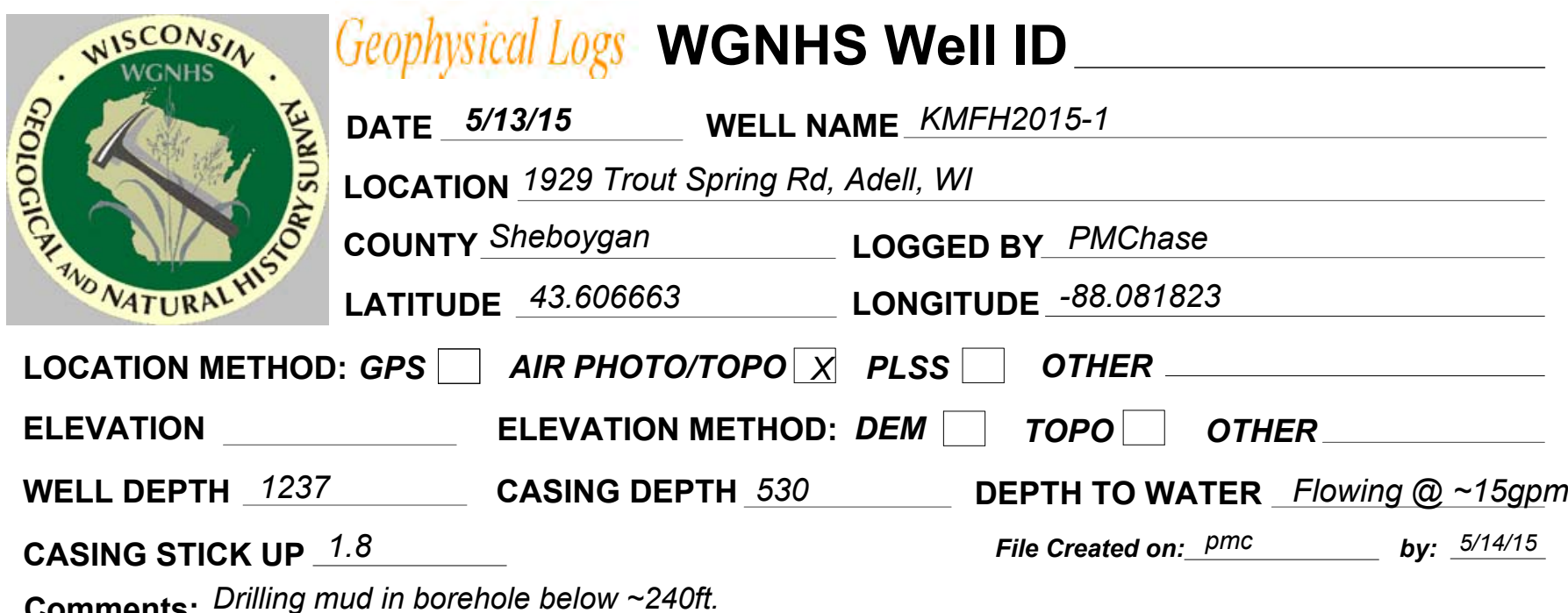

Comments: Drilling mud in borehole below $\sim 240 f t$.

\section{LOGS COLLECTED:}

\begin{tabular}{l|ll} 
Gamma & $X$ & Fluid Conductivity \\
Caliper & $X$ & Flow Meter- HeatPulse \\
Single Point Resistivity & $X$ & Flow Meter- Spinner \\
Self Potential & $X$ & Optical Borehole Imager \\
Normal Resistivity & $X$ & Acoustic Borehole Image \\
Fluid Temperature & $X$ & OTHER:
\end{tabular}

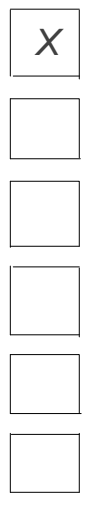

Unless Noted:

$$
\begin{aligned}
& \text { - all depths are in feet } \\
& \text { - well depth, casing depth and depth } \\
& \text { to water are interpreted from } \\
& \text { geophysical log } \\
& \text { - datum is the top of casing }
\end{aligned}
$$

For more information or to obtain collected data not shown please contact us at askageologist@uwex.edu

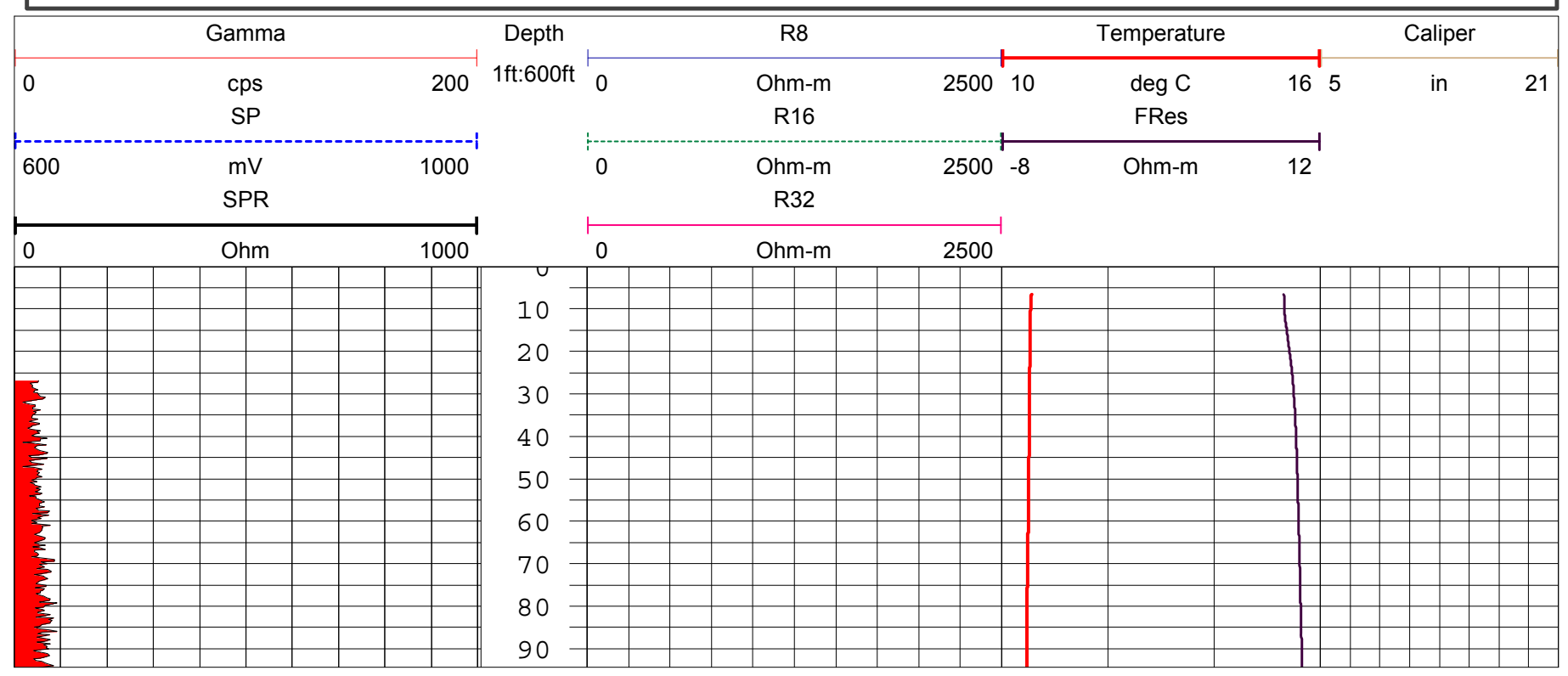

Figure 1-3. Geophysical logs of the monitoring well (MW) at the Kettle Moraine Springs State Fish Hatchery, Sheboygan County, Wisconsin. 

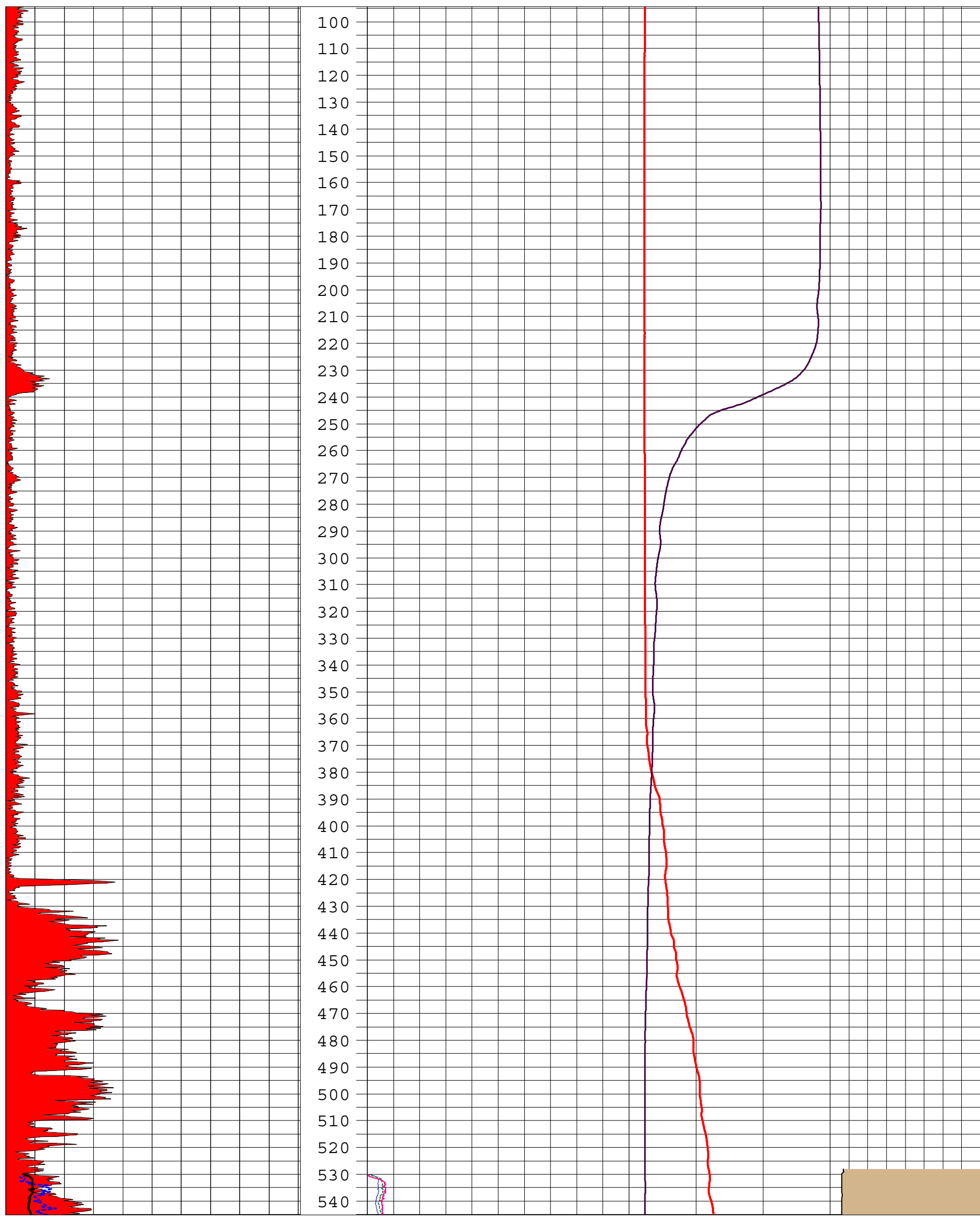

Figure 1-3. Geophysical logs of the monitoring well (MW) at the Kettle Moraine Springs State Fish Hatchery, Sheboygan County, Wisconsin. Continued 

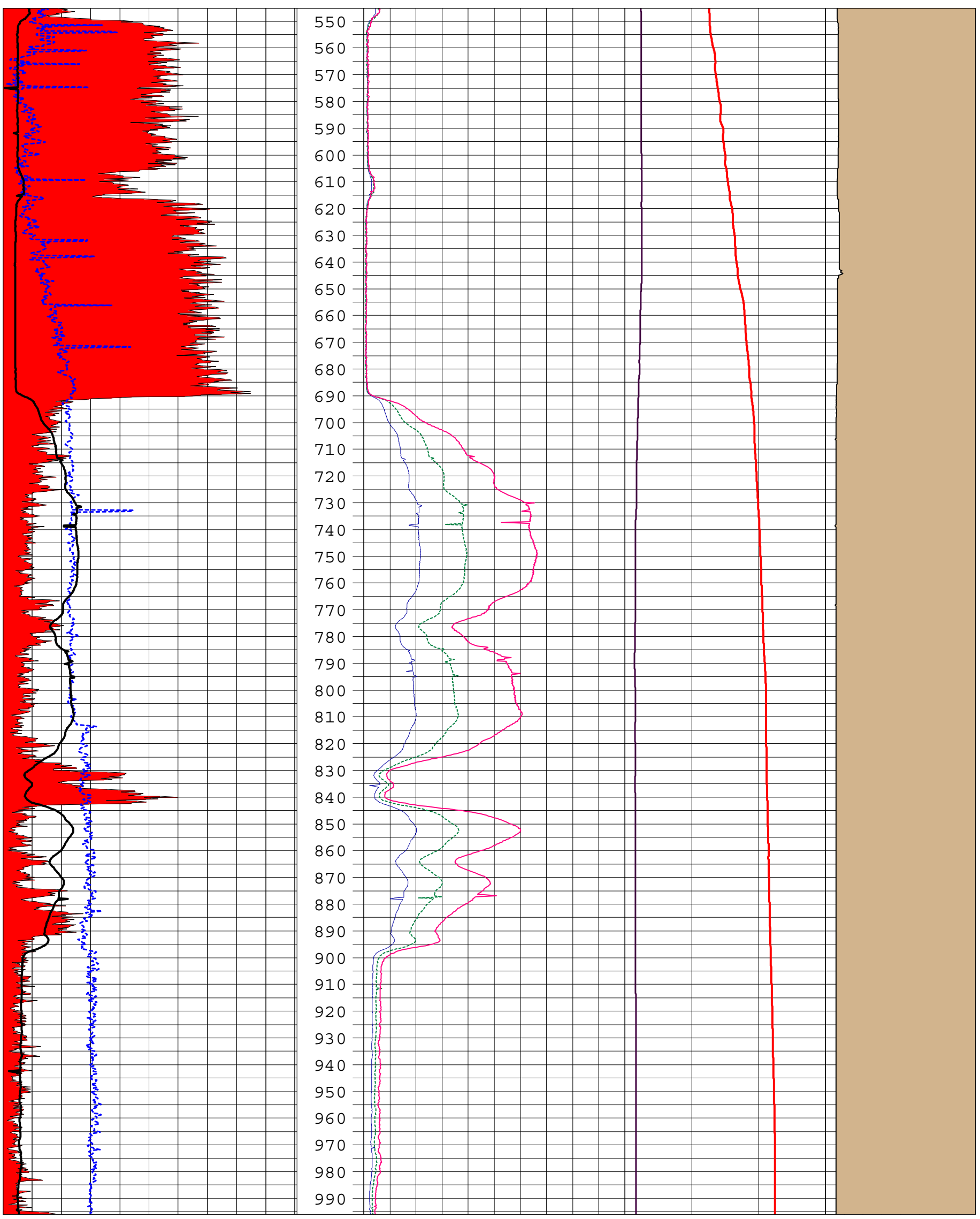

Figure 1-3. Geophysical logs of the monitoring well (MW) at the Kettle Moraine Springs State Fish Hatchery, Sheboygan County, Wisconsin. Continued 

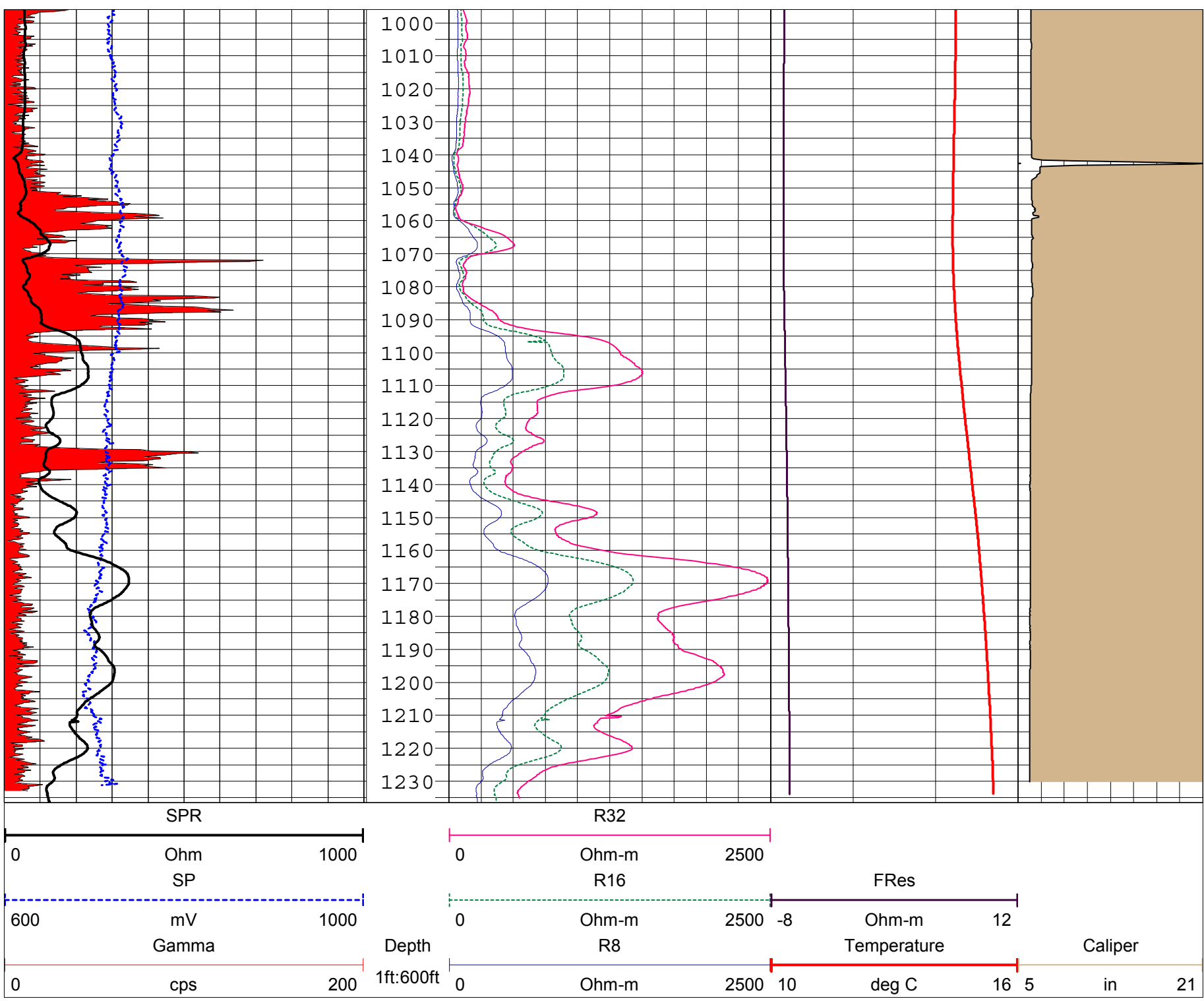

Figure 1-3. Geophysical logs of the monitoring well (MW) at the Kettle Moraine Springs State Fish Hatchery, Sheboygan County, Wisconsin. Continued 
Table 1-2. Well construction data for the test production well (PW1) and monitoring well (MW) at the Kettle Moraine Springs State Fish Hatchery, Sheboygan County, Wisconsin. Table follows the data elements of the State of Wisconsin Well Construction Reports (Wisconsin Department of Natural Resources, 2016).

[datum, North American Vertical Datum of 1988 (NAVD 88); - , indicates not applicable or no data]

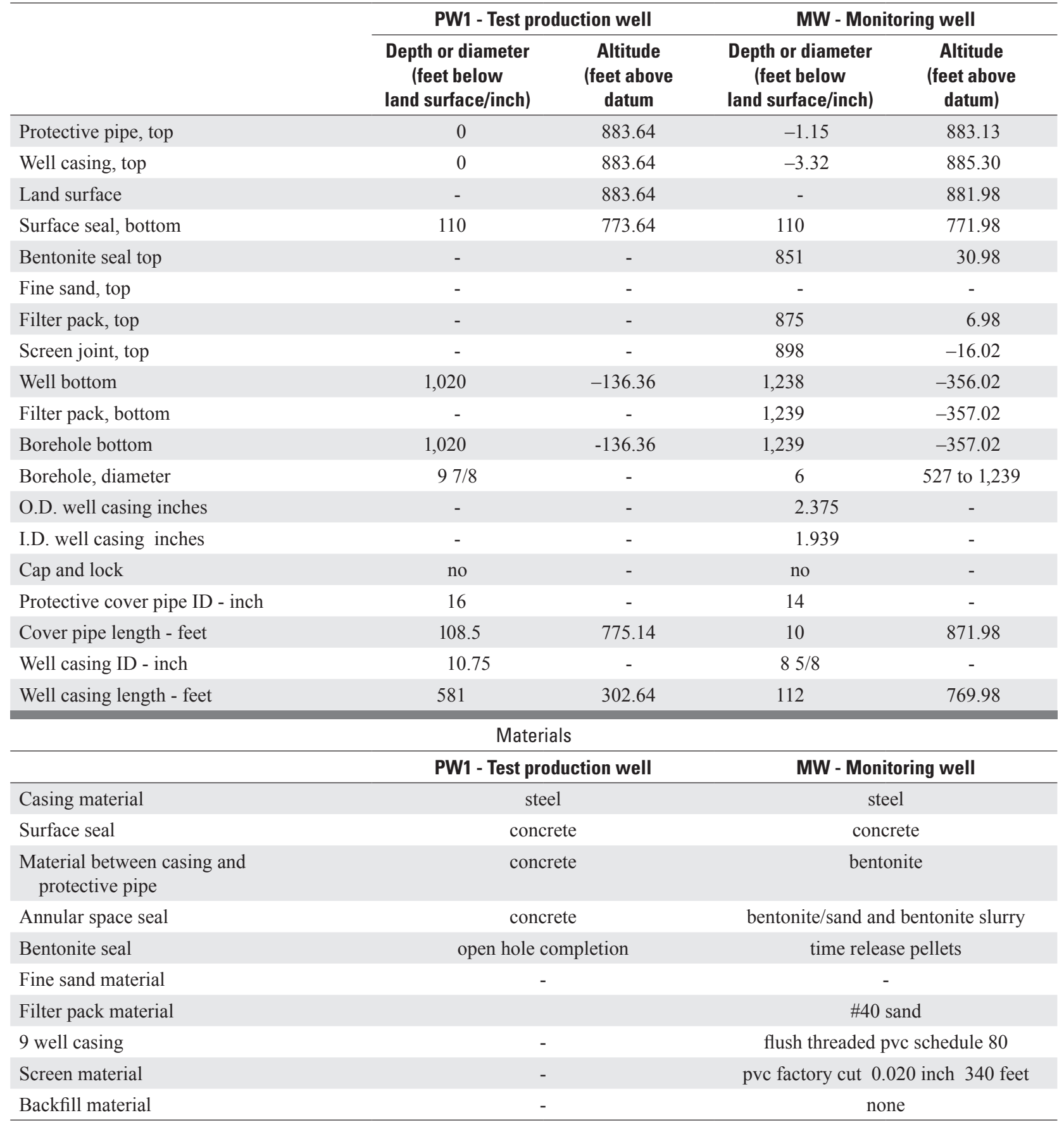




\section{Monitoring Well Completion}

The completion of the monitoring well, MW, refers to its uncased, screened interval. The MW is completed in the COAS over a depth interval from 898 to $1,238 \mathrm{ft}$ below land surface (an altitude interval from about -16 to $-356 \mathrm{ft}$ relative to the NAVD 88 datum). The screened interval includes all or parts of the Ancell, Prairie du Chien-Trempealeau, and Elk Mound Groups. The well is completed as a sand pack behind a 2-inch polyvinyl chloride screen (0.020 inch slot size). Well construction details are presented in table 1-2.

\section{References Cited}

Wisconsin Department of Natural Resources, 2016, The groundwater retrieval network, accessed October 2016 at http://dnr.wi.gov/topic/Groundwater/grn.html.

Wisconsin Geological and Natural History Survey, 2011, Bedrock stratigraphic units in Wisconsin: Wisconsin Geological and Natural. History Survey Educational Series 51, $4 \mathrm{p}$. 



\section{Appendix 2. Design and Performance of Aquifer Pumping Test in the Cambrian- Ordovician Aquifer System}

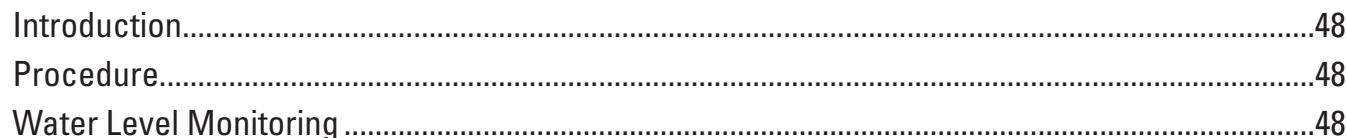

\section{Figures}

2-1. Graph showing pumping during constant rate aquifer pumping test conducted at the Kettle Moraine Springs State Fish Hatchery in Sheboygan County, Wisconsin

2-2. Depth to water measurements collected from $A$, the test production well (PW1), and $B$, the monitoring well (MW) during the 2015 step test and constant rate aquifer pumping test conducted at the Kettle Moraine Springs State Fish Hatchery, Sheboygan County, Wisconsin.. 


\section{Introduction}

While there are many supply wells that draw water from the Cambrian-Ordovician aquifer system (COAS) in southeastern Wisconsin, there are only a few wells in Sheboygan County or neighboring counties close to the Kettle Moraine Springs State Fish Hatchery (KMSSFH). Because of the lack of well information, only general assumptions could be made about the aquifer yield and water quality.

To address this lack of information, an aquifer pumping test was conducted at the KMSSFH to assess pumping rates from units of the COAS and to determine aquifer hydraulic properties based on measured drawdown at the monitoring well (MW) under pumping stress. Aquifer hydraulic properties were determined by using the PT model (developed during this study) to simulate observed drawdown in the MW (discussed in appendix 3). The calibrated aquifer hydraulic properties were then used to update the Lake Michigan Basin model (LMB model) to create the LMB modified model, which was used to evaluate the regional effect of sustained pumping of water supply under scenarios of expanded hatchery operations (discussed in appendix 5).

The aquifer pumping test was composed of a stepdrawdown test followed by a recovery period and a constantrate test followed by a recovery period. These tests were conducted during the period September 11-30, 2015. Water levels were measured in the production test well (PW1) (Site identification [ID] 433635088050701) and the MW (Site ID 433624088045502) (fig. 1-1) during this entire period of pumping and recovery.

The PW1 and MW were instrumented with pressure transducers to record water level and temperature throughout the test and recovery period. The data are summarized in this appendix through a series of tables and graphs. Raw and processed data have been archived in the Wisconsin Water Science Center (WIWSC) and the U.S. Geological Survey (USGS) National Water Information System (NWIS) (http://nwis.waterdata.usgs.gov/wi/nwis/uv?cb_00059=on\&cb_00059=on\&cb_7 $2019=$ on\&format $=$ gif_default\&site_no $=433635088050701 \& \mathrm{cb}$ _72019 $=$ on\&format $=$ gif_default\&site_no $=433624088045501 \&$ period $=\&$ begin_date $=2015-09-10 \&$ end_date $=2015-10-01$ ) .

\section{Procedure}

The aquifer pumping test began on September 11, 2015, and ended September 18, 2015. Monitoring of water levels in PW1 and MW continued throughout the recovery period until September 30, 2015.
The first phase of the aquifer pumping test was a stepdrawdown test that began on September 11 at 11:28 central daylight time (CDT) in which the pumping rate was held constant at about 360 gallons per minute (gal $/ \mathrm{min}$ ) for 3 hours and then increased to about $770 \mathrm{gal} / \mathrm{min}$ for 3 additional hours. The step test ended on September 11 at 17:28 CDT, and aquifer recovery continued for about 3.6 days before the constant rate test was started. The constant rate test was conducted for 72 hours beginning September 15 at 08:39 CDT and ending September 18 at 08:44 CDT. Based on the results of the stepdrawdown test, the constant rate test was maintained at a rate that averaged $862.4 \mathrm{gal} / \mathrm{min}$ (fig. 2-1).

With both the PW and MW completed in deep confined zones separated from the shallow system by the Maquoketa Shale, there was no concern during the test that the disposal of the pumped water at the surface would affect the test results. The water was disposed by directing it through an 8-inch diameter hose to an existing surface pond on the hatchery grounds approximately $700 \mathrm{ft}$ distant. The hatchery staff had lowered the level of the pond in anticipation of receiving water from the aquifer step test and constant-rate test.

\section{Water Level Monitoring}

The water levels were recorded continuously in both PW1 and MW throughout the aquifer step test, pumping test, and recovery periods. Water levels were collected at the PW1 well using a water level datalogger (Solinst levelogger Edge) with levels automatically compensated for barometric pressure changes (Solinst Barologger Edge). The barometric efficiency was assumed to be near 1.0 and no lag correction was made. Water levels were collected at MW with a vented transducer (Campbell Scientific CR-10 logger) to avoid the need for barometric pressure corrections. Water levels from the step test onward were not corrected for background trend. It is assumed that any background trend in the deep aquifer water levels is overwhelmed by the effect of the initial step test before the constant-rate test and recovery period. Tidal effects are assumed to be negligible.

These water-level data demonstrate the response to the different pumping rates stressing the aquifer for the 6-hour step test and the 72-hour constant rate aquifer pumping test. The data also demonstrate the quick recovery of water levels once pumping ended and the longer-term return to (near) prepumping levels. Monitoring of recovery continued for about 12 days until water levels returned to near pretest levels and ended on September 30 (fig. 2-2). Because the COAS is well confined by the Maquoketa confining unit, no monitoring of the upper aquifer or surface water features or shallow aquifers was conducted. 


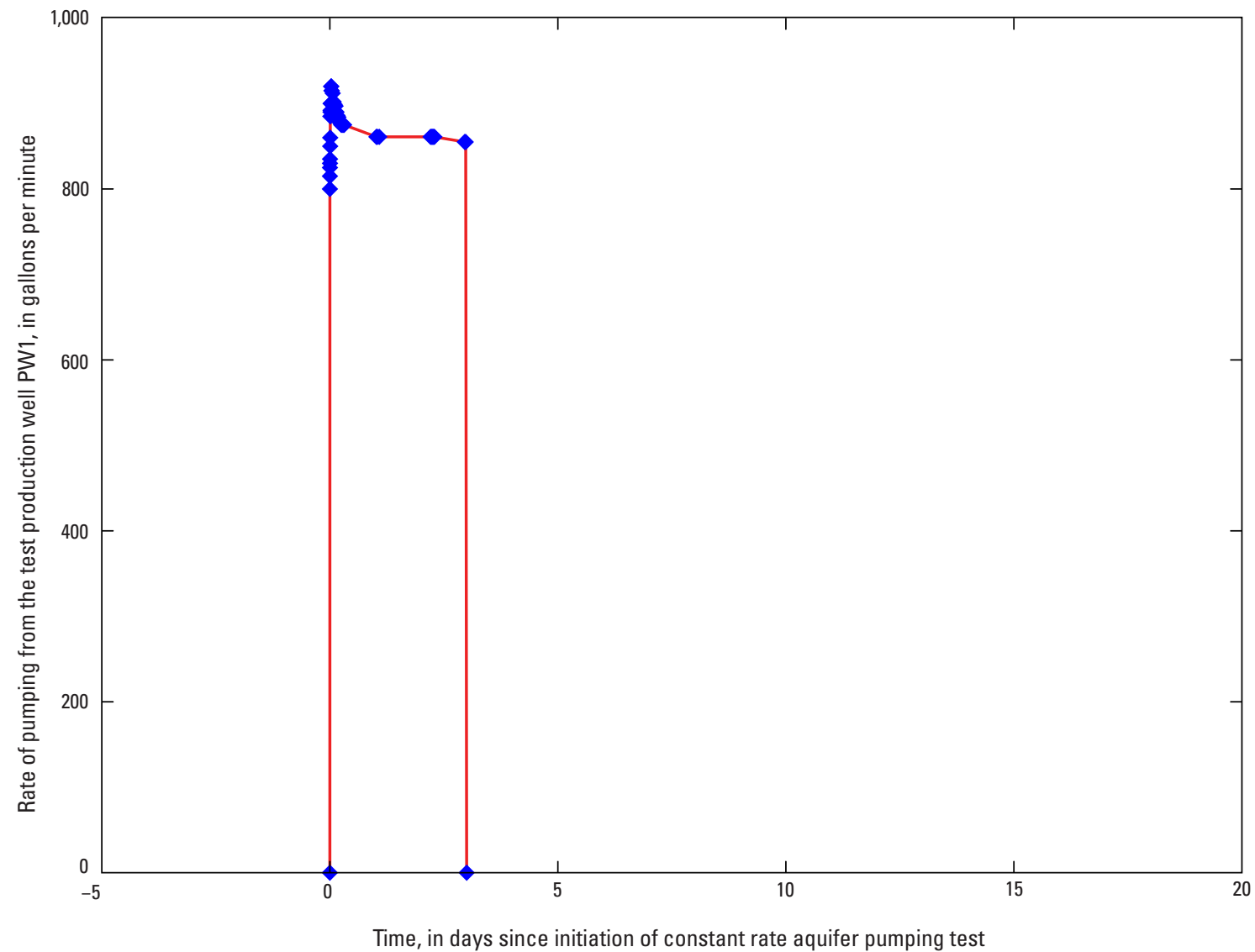

EXPLANATION

- Measured pumping rate

_ Interpolated pumping rate

Figure 2-1. Pumping during constant rate aquifer pumping test conducted at the Kettle Moraine Springs State Fish Hatchery in Sheboygan County, Wisconsin. 
A. Measured depth to water at production well (PW1)

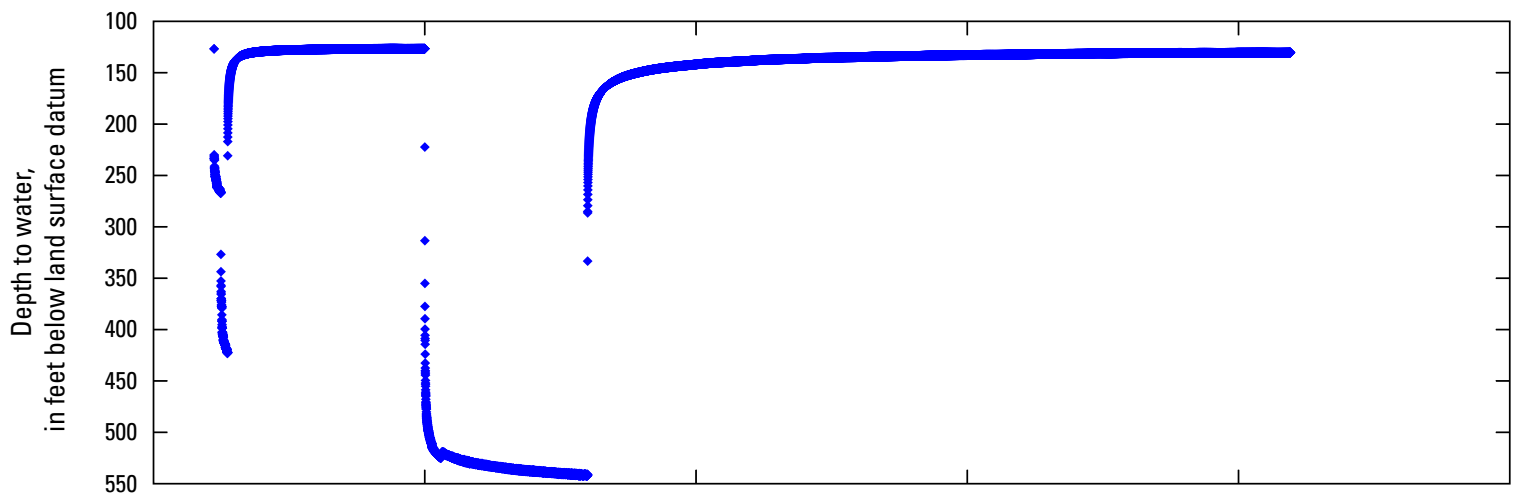

B. Measured depth to water at monitoring well (MW)

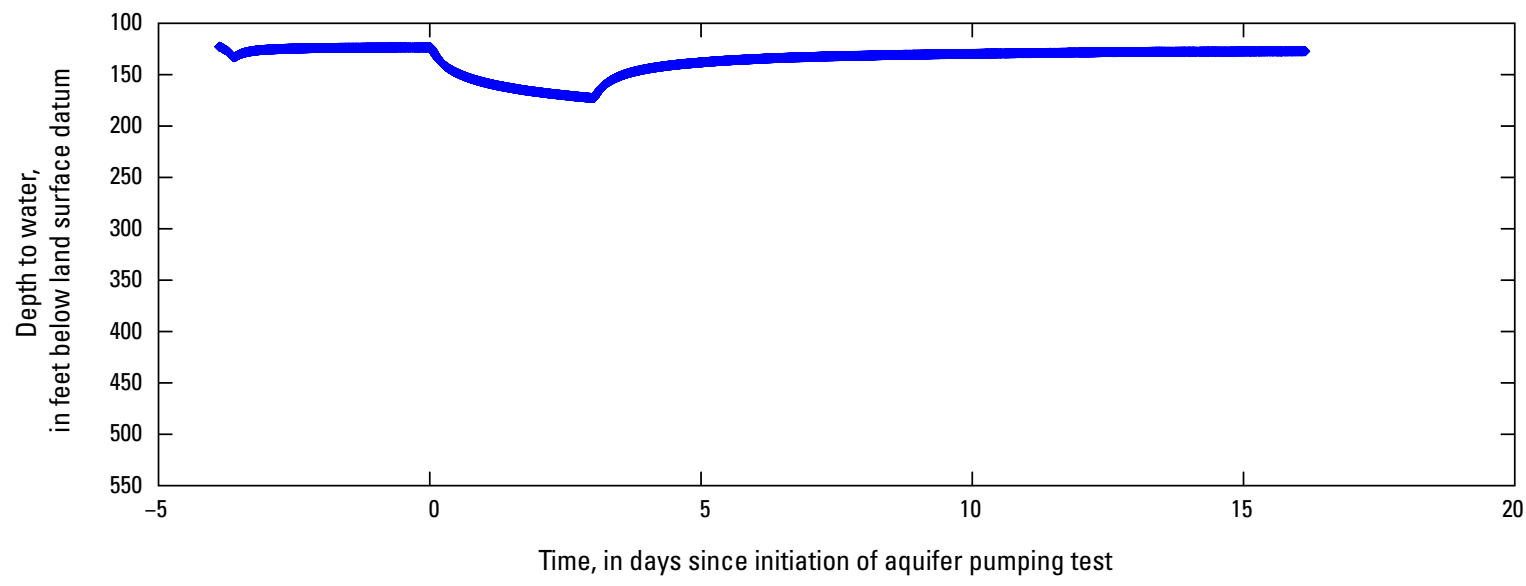

EXPLANATION

- Measured depth to water below land surface datum

Figure 2-2. Depth to water measurements collected from $A$, the test production well (PW1), and $B$, the monitoring well (MW) during the 2015 step test and constant rate aquifer pumping test conducted at the Kettle Moraine Springs State Fish Hatchery, Sheboygan County, Wisconsin. 


\section{Appendix 3. Development of the Pumping Test Model and Interpretation of the Cambrian-Ordovician Aquifer System Pumping Test}

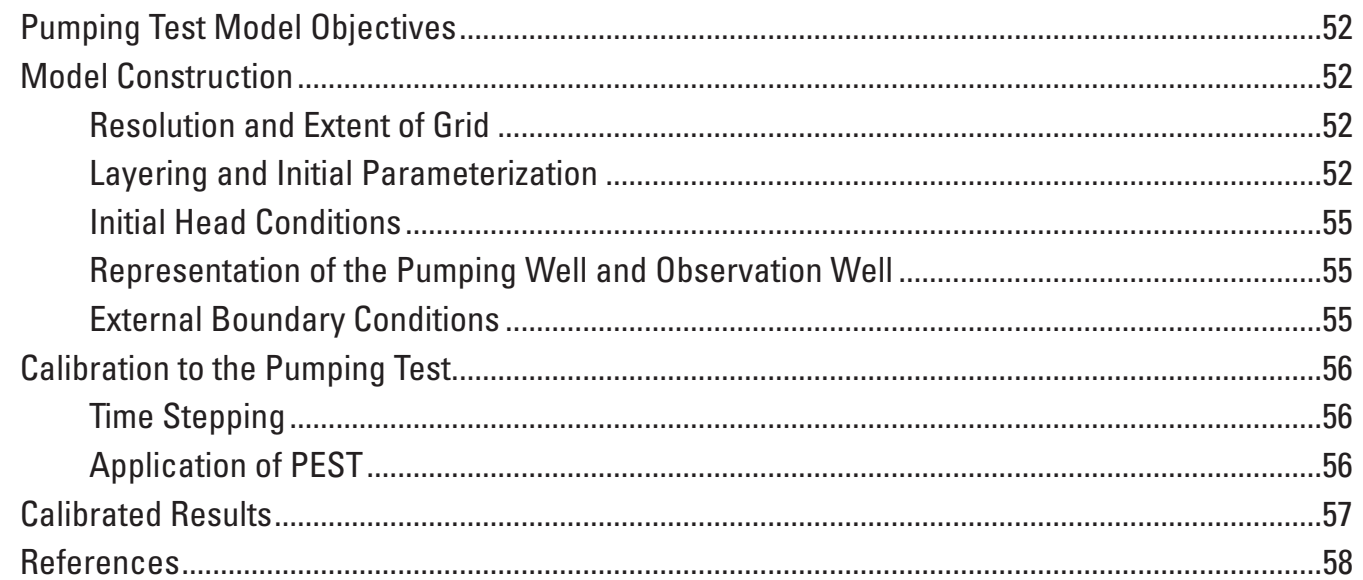

\section{Figures}

3-1. Graphs showing A, Extent of the Pumping Test model domain its irregular grid size, and the zonation of two different scenarios simulating constant heads representing the (1) Maquoketa Shale subcrop and (2) western boundary of the Lake Michigan Basin divide, Wisconsin; $B$, East-west cross section with no vertical exaggeration through the PT model; $C$, East-west cross section with vertical exaggeration of 20x through the PT model

3-2. Graphs showing measured water levels in the $A$, monitoring well (MW) and $B$, test pumping well (PW1) during the aquifer pumping test conducted during September 2015, along with the levels simulated using the calibrated Pumping Test model at the Kettle Moraine Springs State Fish Hatchery in Sheboygan County, Wisconsin

\section{Tables}

3-1. Layer thickness and initial horizontal hydraulic conductivity and calculated transmissivity values of the Pumping Test model, Wisconsin

3-2. The duration and number of stress periods along with the corresponding pumping rate used in the Pumping Test model, Wisconsin 


\section{Pumping Test Model Objectives}

The Pumping Test model (PT model) was constructed for this study to meet two objectives: (1) to help derive hydraulic parameters for the deep Cambrian-Ordovician aquifer system (COAS) from the pumping test described in appendix 2, and (2) to predict drawdown in and around wells pumping from the COAS as part of scenario analyses for hatchery water supply.

The first objective is addressed in this appendix; the second objective is discussed in appendix 5 and the main body of the report. It is worth emphasizing that the aim of the PT model is not to simulate the regional response to deep pumping but rather to simulate the local response around the pumping well (an area dictated by the duration of the pumping test and its extent of influence), and thereby to defensibly update aquifer parameter values in the local area. In contrast, the regional drawdown of pumping from the COAS at the hatchery was simulated using the LMB modified model. The LMB modified model is the LMB model (the parent Lake Michigan Basin regional model of Feinstein and others [2010]) updated with new transmissivity and storativity values based on this analysis of the aquifer pumping test. The simulated regional drawdown in response to proposed pumping in the COAS is also presented in appendix 5.

\section{Model Construction}

The main assumptions guiding the construction of a MODFLOW model to analyze the COAS pumping test conducted at the hatchery site are (1) the COAS locally consists of flat-lying units; (2) each unit is locally homogeneous in terms of thickness, horizontal hydraulic conductivity, and vertical hydraulic conductivity; (3) the storage release of the COAS in response to drawdown can be captured by a single specific storage value applied to all the units. In other words, the PT model largely incorporates assumptions used in a conventional well hydraulics analysis. However, the use of a MODFLOW model in place of an analytical solution does allow more flexibility when it comes to assigning distinct hydraulic conductivity values to each unit; to directly simulating possible vertical leakage through the Maquoketa Shale, which confines the COAS; and to testing the effect of distinct far boundary conditions on the estimated parameters.

The following five subsections provide more detail on the assumptions guiding model construction. The subsequent "Model Calibration" section describes the analysis in terms of adjustment of the input parameters of the model to match the entire drawdown and recovery record observed during the preliminary step test, during the period of no pumping subsequent to the step test, during the constant-rate pumping test, and during the subsequent recovery period. This entire sequence of pumping and nonpumping periods is simulated using multiple model stress periods. The model analysis via calibration is conducted for the entire record of drawdown and recovery at both the single observation well and at the pumping well itself (taking account of well loss through the skin of the pumping well).

\section{Resolution and Extent of Grid}

The MODFLOW PT model is centered on the location of the test production well (PW1) installed in the deep aquifer (see appendix 1). The model grid is nonuniform, expanding outward from the row and column location hosting PW1. This central node is 4 feet (ft) on a side. A multiplication factor of 1.15 is applied to the spacing in both the east/west (column) and north/south (row) directions. The PT model has 129 rows and 129 columns (that is, 64 nodes extend to the east, west, north, and south of the central node). The total dimension of the square grid is 89.06 miles (mi) from east to west and $89.06 \mathrm{mi}$ from north to south (fig. 3-1A). This nonuniform grid design allows refined estimates of drawdown around the PW1 and MW locations but minimizes the effect of the edge boundaries of the model by moving them far from the pumping test location.

\section{Layering and Initial Parameterization}

The PT model was constructed with eight layers. The top layer is the shallow part of the groundwater-flow system (glacial deposits and Silurian units), which is represented by constant head cells corresponding to the initial head condition everywhere in the model (fig 3-1B). The Maquoketa Shale constitutes layer 2 of the model. The remaining six layers correspond to the following units in the COAS (from top to bottom):

1. Sinnipee Group dolomite aquifer/confining unit,

2. Ancell Group - St. Peter sandstone aquifer unit,

3. Prairie du Chien Group dolomite-Trempealeau Group sandstone aquifer/confining unit,

4. Elk Mound Group - Ironton-Galesville sandstone aquifer unit,

5. Elk Mound Group - Eau Claire fine sandstone and shale aquifer/confining unit, and

6. Elk Mound Group - Mount Simon sandstone aquifer unit.

The characteristics of these Cambrian and Ordovician units are described in Feinstein and others (2010).

Because the PT model is designed to simulate the local response to pumping, the layer thicknesses in the model are set to constant values corresponding to the intervals identified at the location of the monitoring well (MW) (see appendix 2). These thicknesses are listed in table 3-1. The top layer of the model is above the confining Maquoketa Shale, and therefore is not considered in analyses performed with the PT model. 


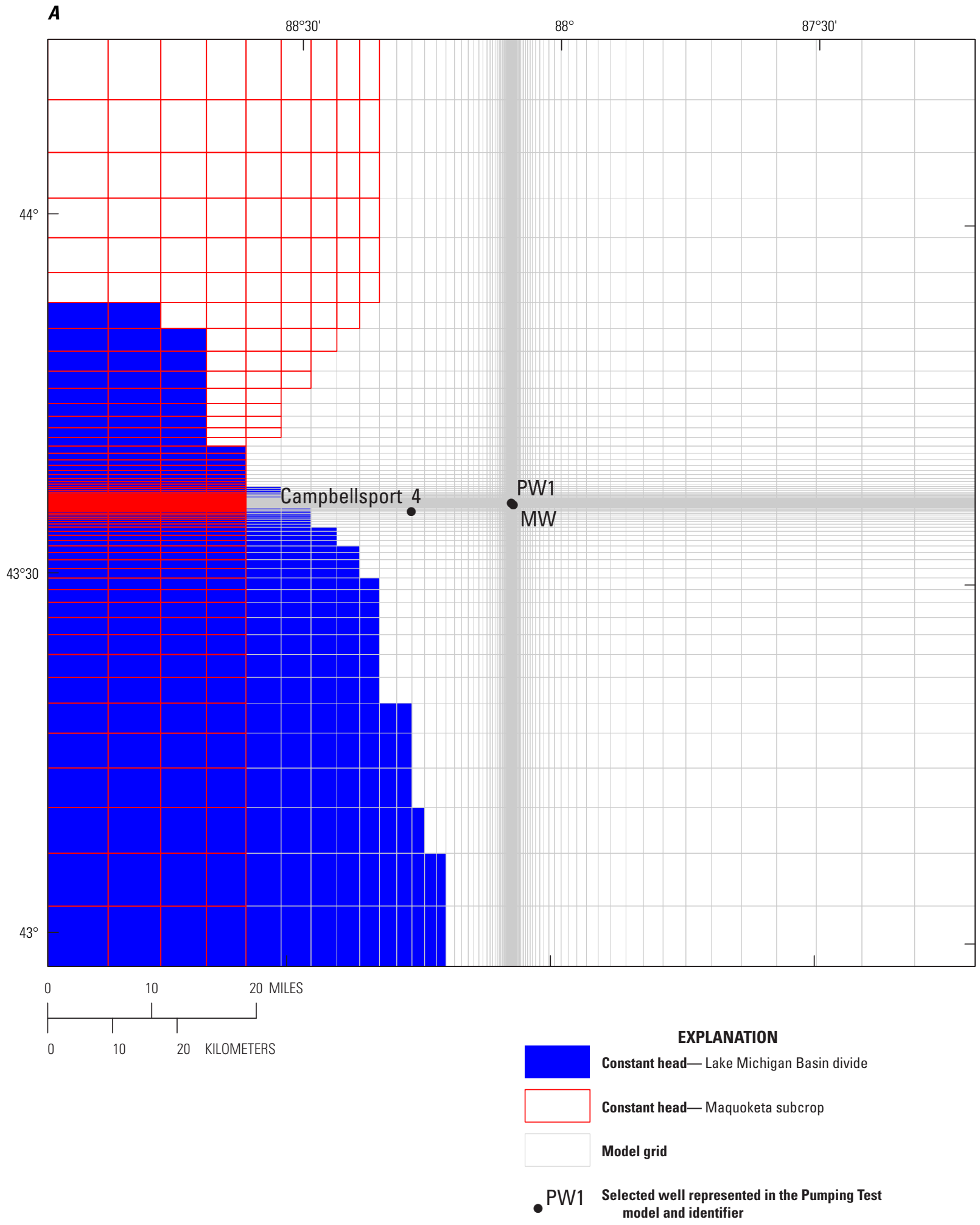

Figure 3-1. A, Extent of the Pumping Test (PT) model domain, its irregular grid size, and the zonation of two different scenarios simulating constant heads representing the (1) Maquoketa Shale subcrop and (2) western boundary of the Lake Michigan Basin divide, Wisconsin. The location of this model domain is shown in figure 7; $B$, East-west cross section with no vertical exaggeration through the PT model; $C$, East-west cross section with vertical exaggeration of 20x through the PT model; the multi-node wells representing the test production well and the monitoring well are shown in the center of the grid; constant head cells in layer 3 are representing the western boundary of the Lake Michigan Basin divide, Wisconsin. 


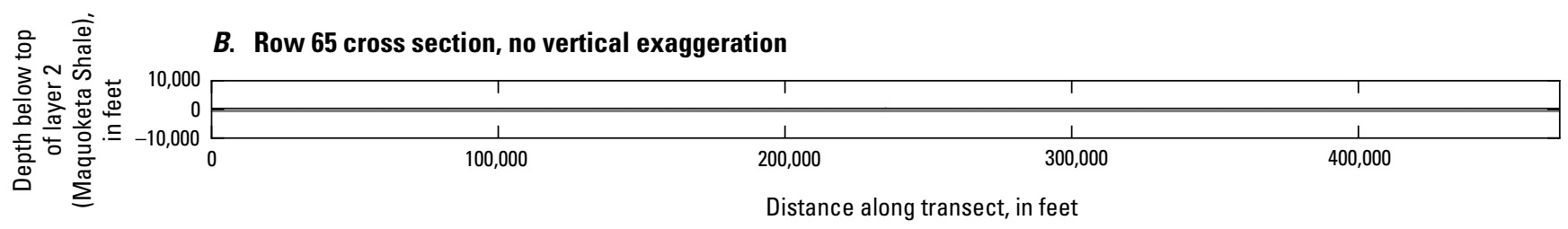

C. Row 65 cross section, vertical exaggeration $=100 x$

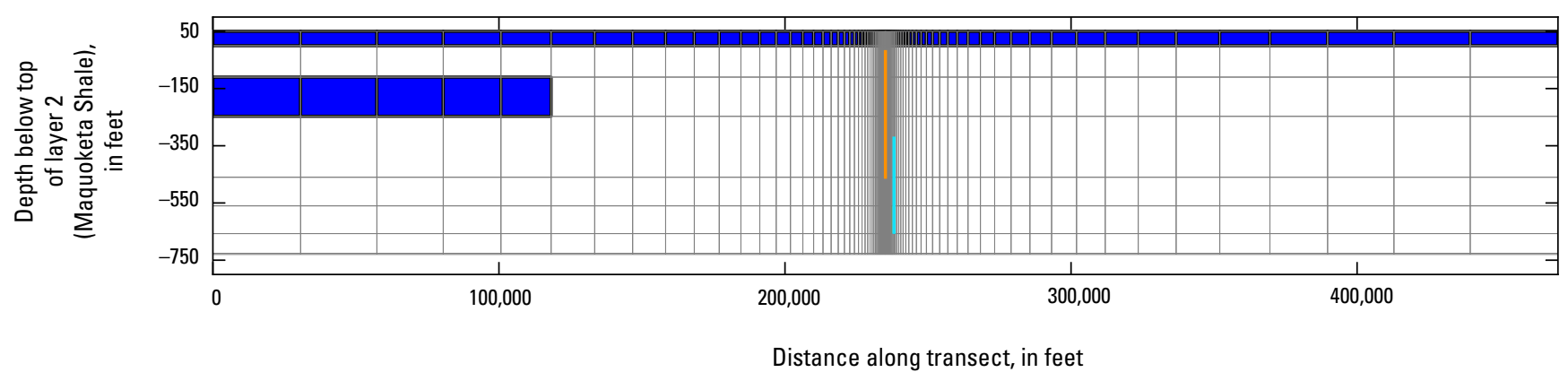

EXPLANATION

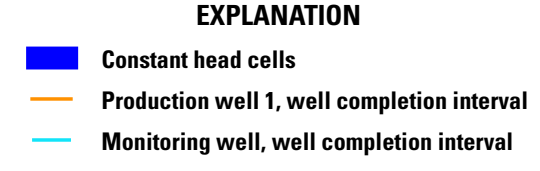

Figure 3-1. A, Extent of the Pumping Test (PT) model domain its irregular grid size, and the zonation of two different scenarios simulating constant heads representing the (1) Maquoketa Shale subcrop and (2) western boundary of the Lake Michigan Basin divide, Wisconsin. The location of this model domain is shown in figure 7; $B$, East-west cross section with no vertical exaggeration through the PT model; $C$, East-west cross section with vertical exaggeration of $20 x$ through the PT model; the multi-node wells representing the test production well and the monitoring well are shown in the center of the grid; constant head cells in layer 3 are representing the western boundary of the Lake Michigan Basin divide, Wisconsin.—Continued

Table 3-1. Layer thickness and initial horizontal hydraulic conductivity and calculated transmissivity values of the Pumping Test model, Wisconsin.

[-- , indicates not applicable or no data]

\begin{tabular}{|c|c|c|c|c|}
\hline Stratigraphic unit ${ }^{1}$ & $\begin{array}{l}\text { Pumping Test } \\
\text { layer number }\end{array}$ & $\begin{array}{l}\text { Pumping Test } \\
\text { layer thickness } \\
\text { (feet) }\end{array}$ & $\begin{array}{c}\text { Pumping Test } \\
\text { initial horizontal } \\
\text { hydraulic } \\
\text { conductivity } \\
\text { (feet per day) }\end{array}$ & $\begin{array}{c}\text { Pumping Test } \\
\text { initial } \\
\text { transmissivity } \\
\text { (square feet } \\
\text { per day) }\end{array}$ \\
\hline Maquoketa Shale confining unit & 2 & 110 & 0.10 & 11 \\
\hline Sinnipee Group aquifer/confining unit & 3 & 137 & 1.01 & 138 \\
\hline Prairie du Chien-Trempealeau Groups aquifer/confining unit & 5 & 100 & 0.22 & 22 \\
\hline Elk Mound Group-Ironton-Galesville aquifer unit & 6 & 97 & 2.67 & 259 \\
\hline Elk Mound Group-Eau Claire aquifer/confining unit & 7 & 69 & 1.15 & 79 \\
\hline Elk Mound Group-Mount Simon aquifer unit & 8 & -- & -- & -- \\
\hline Total & & 726 & & 1,690 \\
\hline
\end{tabular}

${ }^{1}$ Wisconsin Geological and Natural History Survey, 2011, Bedrock stratigraphic units in Wisconsin 
The monitoring well was drilled to a depth believed to be just above the Eau Claire Formation; therefore, the thickness for layer 7 (Eau Claire aquifer/confiing unit) is taken from the layering of the LMB model for this area. Layer 8 (Mount Simon aquifer unit) is assumed to have negligible thickness and transmissivity at this location.

The table also shows the initial horizontal hydraulic conductivity values assigned to each model layer. These values are identical to the calibrated values in the unconfined version of the LMB regional model (Feinstein and others, 2010). In general, layers with greater sandstone content have higher conductivity values than the units containing appreciable amounts of carbonates or shale. The combined thickness and transmissivity of the Cambrian-Ordovician units are $726 \mathrm{ft}$ and 1,689 square feet per day ( $\left.\mathrm{ft}^{2} / \mathrm{d}\right)$, respectively. These initial hydraulic conductivity values were updated as a result of the calibration process to reflect the local aquifer response during the pumping test.

\section{Initial Head Conditions}

Because the COAS is confined, no desaturation of any of the layers was allowed (that is, the MODFLOW LAYCON parameter is set to zero). Because the PT model is intended to simulate drawdown in the deep aquifer rather than water levels, it acts as a "superposition" transient model (Leake and others, 2008; Anderson and others, 2015). The problem of defining initial conditions then disappears because the initial conditions are defined as zero drawdown (or change in head) everywhere in the system (Franke and others, 1987). A constant and arbitrary initial head altitude of $1,000 \mathrm{ft}$ is specified everywhere in the model domain. A simulated water level value of $600 \mathrm{ft}$, for example, would therefore represent a drawdown value of $400 \mathrm{ft}$.

\section{Representation of the Pumping Well and Observation Well}

The pumping well, PW1, is located in row 65 , column 65 , at the center of the model grid. The well is simulated using the MODFLOW Multi-Node Well (MNW2) package (Konikow and others, 2009). This package allows the well to span multiple layers and distributes the pumping from individual layers based on their relative transmissivities. In addition, it allows MODFLOW to calculate not only the average water level in the cells penetrated by the well but also the single water level inside the borehole that considers aquifer loss inside the penetrated cells as well as the skin effect caused by a potential disturbed zone because of drilling. For this analysis, the extent of the skin was assumed to be thin, corresponding to a $11 / 5$-inch annular radius around a 4 15/16-inch radius borehole. The hydraulic conductivity of the skin was estimated during calibration.
The open (uncased) interval of PW1 extends over part of the Maquoketa Shale and all the thickness of the Sinnipee and Ancell Groups (see appendix 1, fig. 1-2). The observation well, MW, is by contrast open to only part of the Ancell Group but also the Prairie du Chien-Trempealeau Groups and upper units of the Elk Mound Group. The MW is drilled at a distance of 1,470 ft from PW1 (appendix 1, fig. 1-1), occupying row 91, column 91 in the PT model. Just like PW1, the MW was simulated using the MNW2 package, although with zero pumping. The MNW2 package can simulate the response inside this borehole as a single drawdown value that accounts for varying transmissivities among the associated model layers.

\section{External Boundary Conditions}

Because of the large extent of the PT model domain, the perimeter boundary conditions for the PT model were expected to have limited effect on the simulated results for either the short-term aquifer pumping test analysis or the long-term scenario testing. Sensitivity tests were simulated to confirm this expectation. A uniform constant head equal to the initial head of $1,000 \mathrm{ft}$ was assigned to model layer 1, representing the shallow, unconfined part of the flow system. Because layer 1 is separated from the COAS by the Maquoketa Shale, there is negligible flow induced downward by pumping (see below for flux results under pumping test and scenario simulations). The lateral boundary conditions for all layers at the edge of the grid are very distant from the simulated hatchery pumping center at the center of the grid (closest at about $44.5 \mathrm{mi}$ ) and, therefore, are set to a no-flow condition. However, the geometry of the COAS is asymmetric from east to west. Whereas the aquifer continues as a confined system to the east under Lake Michigan, it encounters unconfined conditions to the west as the Maquoketa Shale becomes thinner around the location of the subcontinental topographic divide between the Lake Michigan Basin and the Mississippi River Basin. The Maquoketa Shale finally disappears about 23 $\mathrm{mi}$ west of the hatchery site. This western hydrologic boundary effectively serves as a second source of water to the pumping well, supplementing water withdrawn from aquifer storage. The possible effect of downward leakage to the deep aquifer from the west in response to drawdown because of pumping was simulated in two ways: (1) the base case - a constant head equal to the initial head of $1,000 \mathrm{ft}$ was added along the Lake Michigan Basin Divide in the Sinnipee Group (the unit underlying the Maquoketa Shale) corresponding to layer 3 of the PT model (figs. 3-1A and 3-1B); and (2) the sensitivity case - the same 1,000 - $\mathrm{ft}$ constant head was added along the subcrop boundary for the Maquoketa Shale instead of along the Lake Michigan Basin Divide

(fig. 3-1A). In the "Final Parameter Values" section of this appendix, the drawdown results at the proposed hatchery pumping center are shown to be indistinguishable for the pumping test simulations that incorporate these two different constant head boundary conditions to the west. 


\section{Calibration to the Pumping Test}

There are multiple ways to analyze an aquifer pumping test in order to derive aquifer parameter values (in this case, transmissivity and storativity) from the drawdown response at a pumping well and observation well. In this case, the numerical model described above was used to perform the inverse analysis, where the measured response in the aquifer is used to estimate properties of that aquifer. The PT model is transient, taking account of the water released by storage to PW1 as a result of drawdown. The basic computational strategy is to input the pumping during the test into the model, to simulate the drawdown inside PW1 and at the observation well MW, and to compare the simulated drawdown to the measured data described in appendix 2 . This procedure was extended to consider pumping activity and water-level recovery before the test and water-level recovery after the test. Model parameters are varied to attain a better fit to the field measurements, a process referred to as history matching (Anderson and others, 2015, chapter 9).

\section{Time Stepping}

An important condition for successful analysis of an aquifer pumping test is that pretest conditions are stable or that they are explicitly simulated. The 3 -day pumping test of the COAS at the hatchery site was preceded by a 6 -hour step test conducted about 3.6 days before the beginning of the pumping test (appendix 2). Monitoring of water levels demonstrated that the influence of the step test was present at the beginning of the pumping test in the form of residual drawdown. As a result, it was not possible to begin the model simulation at the beginning of the constant rate pumping test but rather at the beginning of the step test that was used to determine the appropriate pumping rate for the pumping test itself (appendix 2).

The pumping test simulation consists of a series of stress periods in which the withdrawal from the pumping well is kept constant for the duration of the stress period. There are four sets of stress periods. The first set of two stress periods represents pumping during the preliminary step test. Each stress period is 3 hours long to accommodate the two pumping rates sustained during the step test. The second set includes a stress period corresponding to the 3.63 days of recovery after the step test and before the pumping test during which the pumping rate is set to zero. The third set consisted of 25 stress periods devoted to the pumping test. This number is needed to accommodate the slightly varying pumping rate (averaging 862.4 gallons per minute) recorded during the pumping test. The fourth and last set consists of one stress period that represents 13 days of monitored recovery after the cessation of pumping. The duration and number of stress periods along with the corresponding pumping rate are listed in table 3-2. The transient PT model solved for head at every model cell (and for drawdown equal to 1,000 ft minus the head) at various times steps during each stress period.

\section{Application of PEST}

The history matching included an initial manual trialand-error fit followed by an automated history matching using the software PEST (Doherty, 2014). The model version that used a constant head corresponding to the western topographic boundary of the Lake Michigan Basin, the base case, was used for history matching. After each calibration attempt, the resulting optimal parameter values were evaluated for reasonableness relative to published ranges. The final PEST-calibrated model incorporated reasonable parameter values (conductivity and storage) and also matched the drawdown and recovery water levels measured at PW1 and MW during the test.

History matching consisted of fitting simulated equivalent outputs to 246 field water-level observations collected during the pumping tests. Because the model used the MNW2 package, measurements from both PW1 and MW were used as targets for history matching; however, the history matching weighted MW measurements $(\mathrm{PEST}$ weight $=1.0)$ more than PW1 measurements (PEST weight $=0.01)$ because of well loss and other effects that can confound head measurements in the pumping well of a test. As a result, the calibration depended much more heavily on measurements from the MW.

The relative horizontal hydraulic conductivities of MODFLOW input values for the Maquoketa Shale and the six units constituting the aquifer system were "tied together" so that they all were adjusted in concert during history matching.

Table 3-2. The duration and number of stress periods along with the corresponding pumping rate used in the Pumping Test model, Wisconsin.

\begin{tabular}{lccc}
\hline & Stress periods & $\begin{array}{c}\text { Duration } \\
\text { (days) }\end{array}$ & $\begin{array}{c}\text { Average pumping } \\
\text { (gallons per minute) }\end{array}$ \\
\hline Step test & 2 & 0.25 & 565.0 \\
Recovery & 1 & 3.63 & 0.0 \\
Pumping Test & 25 & 3.00 & 862.4 \\
Recovery & 1 & 13.00 & 0.0 \\
\hline Total & 29 & 19.88 & \\
\hline
\end{tabular}


Vertical hydraulic conductivity $\left(\mathrm{K}_{\mathrm{v}}\right)$ was not estimated as no vertically nested field measurements were available; therefore, the $\mathrm{K}_{\mathrm{v}}$ values remained identical to those reported for the LMB parent model. Thus, three model parameters were varied to improve the model's fit to the field measurements: (1) storativity (S) of the aquifer, (2) bulk transmissivity of the COAS (hydraulic conductivity times saturated thickness), and (3) borehole skin properties that reflect imperfect connection between the well and the aquifer that results from well drilling, completion, and development. Specifically, the history matching included processes that updated

1. Transmissivity of the COAS (by means of a single multiplier on the horizontal hydraulic conductivity of the Maquoketa Shale and the six units constituting the aquifer system);

2. Storativity of the aquifer system (by means of a single multiplier on the uniform specific storage value assigned to the ensemble of aquifer layers); and

3. Hydraulic conductivity assigned the skin at the pumping test borehole.

\section{Calibrated Results}

Following the automated history matching using PEST, the bulk transmissivity value of the COAS is $729 \mathrm{ft}^{2} / \mathrm{d}$ (about 0.431 times the initial value). The updated specific storage value is $2.98 \mathrm{e}^{-7} 1 / \mathrm{ft}$ (1.81 times the initial value). The updated borehole skin hydraulic conductivity is $8.79 \mathrm{ft} / \mathrm{d}$ (4.4 times the initial value). Model results were relatively insensitive to skin properties; thus, field measurements primarily constrained estimates of horizontal hydraulic conductivity $\left(\mathrm{K}_{\mathrm{h}}\right)$ and storativity (S). All optimal parameter values were deemed reasonable based on an excellent fit between observed and simulated drawdown values for the aquifer pumping test (fig. 3-2).
The final calibrated PT model matches the field measurements from the MW as well as the drawdowns in PW1 (fig. 3-2) despite the lower calibration weights assigned to the pumping well measurements. The calibrated model was then used to evaluate sources of water to the pumping well. In this simple model designed to simulate conditions around the pumping well, there are three potential sources of water:

1. Storage release of water because of drawdown in the COAS and overlying Maquoketa Shale,

2. Leakage of water from the shallow system (configured as a constant head layer) downward to the aquifer system across the Maquoketa Shale, and

3. Inflow of water from the western boundary where the Maquoketa Shale is thin or absent.

At the end of the pumping phase of the test, the model simulates that 99.9 percent of the water withdrawn by PW1 has its source as storage release. Downward leakage and inflow from the west are negligible sources (both are less than 0.1 percent). Based on the sensitivity simulation, when the western constant-head condition corresponding to the subcrop of the Maquoketa Shale was substituted for the constant head, Michigan Basin divide boundary condition, the simulated drawdowns at PW1 and MW change by less than $0.001 \mathrm{ft}$ relative to the calibrated drawdown. Similarly, changing the boundary condition does not affect the magnitude of storage contribution compared to withdrawal. The insensitivity of the results to the western boundary condition of the PT model is explained by the brevity of the testing period and large distance to the boundary location. Finally, the calibrated parameters from the PT model were used to modify the LMB model, which was better suited for evaluating the potential effects of deep pumping on regional heads and drawdowns in the COAS (presented in appendix 5). 

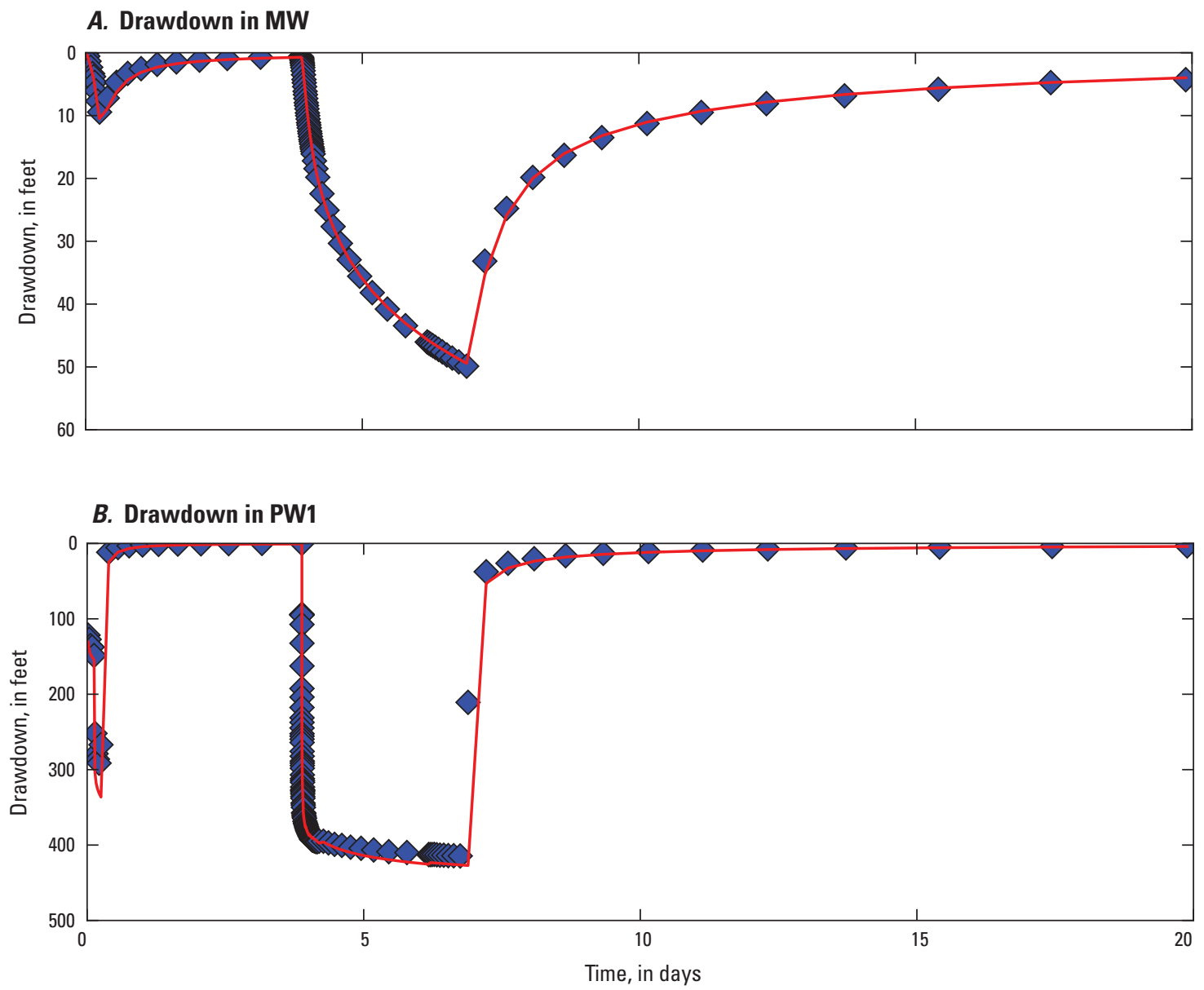

EXPLANATION

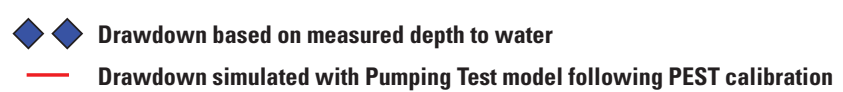

Figure 3-2. Measured water levels in the $A$, monitoring well (MW) and $B$, test pumping well (PW1) during the aquifer pumping test conducted during September 2015, along with the levels simulated using the calibrated Pumping Test model at the Kettle Moraine Springs State Fish Hatchery in Sheboygan County, Wisconsin.

\section{References}

Anderson, M.P., Woessner, W.W., and Hunt, R.J., 2015, Applied groundwater modeling: Simulation of flow and advective transport ( $2 \mathrm{~d}$ ed.): Elevsevier Science, 564 p.

Doherty, John, 2014, PEST, Model-independent parameter estimation-User manual (5th ed., with slight additions): Brisbane, Australia, Watermark Numerical Computing.

Feinstein, D.T., Hunt, R.J., and Reeves, H.W., 2010, Regional groundwater-flow model of the Lake Michigan Basin in support of Great Lakes Basin water availability and use studies: U.S. Geological Survey Scientific Investigations Report 2010-5109, 379 p.
Franke, O.L, Reilly, T.E., and Bennett, G.D., 1987, Definition of initial and boundary conditions in the analysis of saturated ground-water flows systems-An introduction: U.S. Geological Survey Techniques of Water Resources Investigations, book 3, chap. B5, $15 \mathrm{p}$.

Konikow, L.F., Hornberger, G.Z., Halford, K.J., and Hanson, R.T., 2009, Revised multi-node well (MNW2) package for MODFLOW ground-water flow model: U.S. Geological Survey Techniques and Methods, book 6, chap. A30, 67 p.

Leake, S.A., Greer, William, Watt, Dennis, and Weghorst, Paul, 2008, Use of superposition models to simulate possible depletion of Colorado River water by ground-water withdrawal: U.S. Geological Survey Scientific Investigations Report 2008-5189, 25 p. 


\section{Appendix 4. Development of the Kettle Moraine Springs (KMS) Model to Support Analysis of Silurian Aquifer Water Supply}

Extraction from Regional Lake Michigan Basin (LMB) Model to Local Inset

Kettle Moraine Springs (KMS) Model.

Objectives of the Kettle Moraine Springs (KMS) Model ................................................................61

Model Layering and Refinement of Land Surface and Bedrock Surface ........................................63

Updated Aquifer Properties and Boundary Conditions to the Kettle Moraine

Springs (KMS) Model ..................................................................................................63

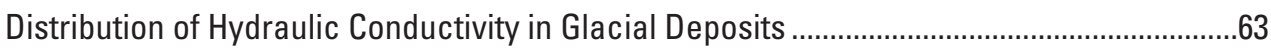

Distribution of Hydraulic Conductivity in Silurian Aquifer .....................................................72

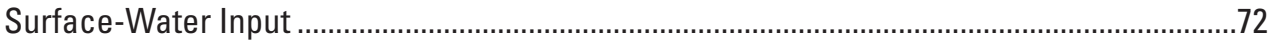

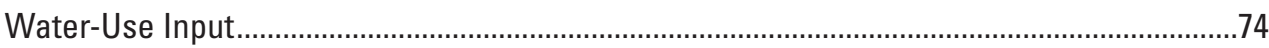

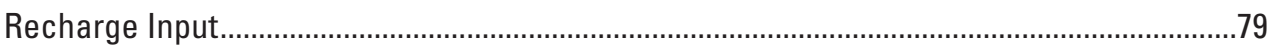

Calibration of Kettle Moraine Springs (KMS) Model ...................................................................

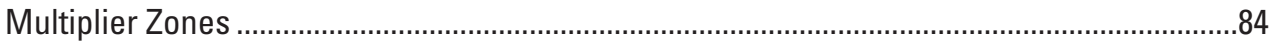

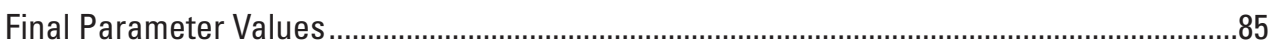

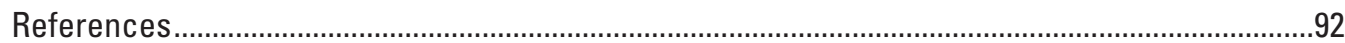

\section{Figures}

4-1. Map showing extent of Kettle Moraine Springs (KMS) model domain extracted from regional Lake Michigan Basin (LMB) model.

4-2. East-west cross section showing hydrostratigraphy of inset Kettle Moraine Springs (KMS) model derived from the parent Lake Michigan Basin (LMB) model.

4-3. Map showing the Silurian bedrock surface within the Kettle Moraine Springs (KMS) model domain after refinement using a kriging process applied to stratigraphic data derived from well construction reports ...

4-4. East-west cross section showing updated model layers 1-6 after refinement of land surface and Silurian bedrock surface. Layering of the deeper layers are inherited from the Lake Michigan Basin (LMB) model

4-5. Maps showing land surface altitude for $A$, the Kettle Moraine Springs (KMS) model domain and $B$, a smaller local area that includes the Kettle Moraine Springs State Fish Hatchery, Sheboygan County, Wisconsin.

4-6. Map showing thickness of glacial deposits in an area that includes the Kettle Moraine Springs State Fish Hatchery, Sheboygan County, Wisconsin..

4-7. Map showing bedrock surface (top of Silurian aquifer) in an area that includes the Kettle Moraine Springs State Fish Hatchery, Sheboygan County, Wisconsin.

4-8. Map showing thickness of the Silurian aquifer in an area that includes the Kettle Moraine Springs State Fish Hatchery, Sheboygan County, Wisconsin 
4-9. Map showing Quaternary geology of the local area around the Kettle Moraine Springs State Fish Hatchery, Sheboygan County, Wisconsin.

4-10. Map showing representation of surface-water features in the Kettle Moraine Springs (KMS) model, Sheboygan County, Wisconsin ...

4-11. Map showing representation of surface-water features in and around the Kettle Moraine Springs State Fish Hatchery as represented in the Kettle Moraine Springs (KMS) model, Sheboygan County, Wisconsin ...

4-12. Groundwater withdrawals, by category, within the Kettle Moraine Springs model domain, Sheboygan County, Wisconsin, exclusive of residential withdrawals. Withdrawals from 2007 to 2012 were averaged

4-13. Map showing wells locations within the Kettle Moraine Springs (KMS) model domain that are actively pumping for the model simulations, Sheboygan County, Wisconsin

4-14. Map showing distribution of recharge as generated by Soil Water Balance method (Westenbroek, 2010) in local area of the Kettle Moraine Springs model, Sheboygan County, Wisconsin

4-15. Map showing multiplier zones of the Kettle Moraine Springs (KMS) model, Sheboygan County, Wisconsin 81

4-16. Map showing groundwater-head targets used in PEST calibration of the Kettle Moraine Springs (KMS) model, Sheboygan County, Wisconsin..

4-17. Map showing flux targets used in PEST calibration of the Kettle Moraine Springs (KMS) model, Sheboygan County, Wisconsin .

4-18. Map showing the resulting final horizontal hydraulic conductivity values for the layer 1 glacial deposits in the local area of the Kettle Moraine Springs (KMS) model, Sheboygan County, Wisconsin .

4-19. Map showing the resulting final horizontal hydraulic conductivity values for the layer 2 glacial deposits in the local area of the Kettle Moraine Springs (KMS) model, Sheboygan County, Wisconsin .

4-20. Graph showing match of simulated water levels (blue squares) to observed head targets following PEST calibration of the Kettle Moraine Springs (KMS) model, Sheboygan County, Wisconsin. The red line is the 1:1 relation line......

4-21. Graph showing match of simulated stream baseflow and spring flux (blue squares) to observed flux targets following PEST calibration of the Kettle Moraine Springs (KMS) model, Sheboygan County, Wisconsin..

4-22. Diagram showing horizontal hydraulic conductivity distribution following calibration along east/west cross section of the Kettle Moraine Springs (KMS) model through hatchery property, Sheboygan County, Wisconsin.

4-23. Map showing distribution of recharge in which the values, generated by the Soil Water Balance method presented in fig. 4-14, have been adjusted by applying multiplication factors following calibration of the Kettle Moraine Springs (KMS) model, Sheboygan County, Wisconsin .

\section{Tables}

4-1. Measured discharge for surface-water sites near the Kettle Moraine Springs State Fish Hatchery, Sheboygan County, Wisconsin, February 2014.

4-2. Calibrated zonal multiplier values for hydraulic conductivity and recharge for the Kettle Moraine Springs (KMS) model, Sheboygan County, Wisconsin .85

4-3. Resulting final hydraulic conductivity values of the local area of the Kettle Moraine Springs (KMS) model, Sheboygan County, Wisconsin. 


\section{Extraction from Regional Lake Michigan Basin (LMB) Model to Local Inset Kettle Moraine Springs (KMS) Model}

It is often advantageous to refine and solve only part of a large coarsely discretized regional model in order to focus on a local management issue. The regional Lake Michigan Basin model (LMB model) simulates shallow and deep groundwater flow over the entire Lake Michigan Basin and surrounding areas (fig. 7) at a coarse scale, using cells that are 5,000 feet (ft) on a side (Feinstein and others, 2010). This coarse discretization limits accurate simulation of groundwater/surface-water interactions and the precise location and interactions of features such as streams, springs, and pumping wells (Feinstein and others, 2010). To overcome these limitations inherent in such a regional model, it is useful to extract a so-called "child" or "inset" model from the "parent" regional model. One common technique for building local inset models is called "telescopic mesh refinement," by which part of the regional parent model grid is refined and bounded by head or flux conditions inherited from the parent model. If the inherited boundary conditions for the local inset model are to be constant, it is important for most applications that the local inset model be large enough so that the boundary conditions have little influence on predictions in the area of interest even when new stresses are added to the solution.

Because the area of interest for this project is the Kettle Moraine Springs State Fish Hatchery (KMSSFH), the local inset model domain selected to achieve the optimization objectives is much larger than the hatchery footprint. The domain of the inset model, named the KMS model, was selected to extend almost the north-south length of Sheboygan County and into neighboring counties to the west and under Lake Michigan to the east (figs. 7 and 4-1). The north/south extent of the KMS model is 21.8 miles (mi), and the east/west extent is $38.8 \mathrm{mi}$.

The lateral grid spacing for the KMS model is uniformly $250 \mathrm{ft}$ on a side. Each LMB model parent cell therefore is replaced by 400 cells in the KMS model. The local KMS model consists of 460 rows and 820 columns. This relatively fine spacing compared to the parent LMB model enabled more accurate simulations of predictions such as the effect of shallow wells on stream base flow (the groundwater discharge component of streamflow).

The initial aquifer properties, internal boundary conditions, geometry, and layering of the KMS model are all inherited from the regional LMB model. For example, the recharge rate for a single LMB model cell was initially assigned to each of the 400 associated cells in the KMS model. However, in the area of the $\mathrm{KMSSFH}$, these model inputs are updated to take advantage of the finer grid discretization of the local inset model.

The boundary conditions of the KMS model are extracted from final stress period results for the LMB model, specifically the 2005 flow conditions (Feinstein and others, 2010). The boundary conditions consist of constant heads along the edge of the inset model for all layers. These conditions remained fixed even if stresses internal to the KMS model, such as pumping rates at the hatchery location, were changed. Because of the distance from the KMSSFH to the edge boundaries and because of the buffering effect of surface-water features between the hatchery location and the edges, changes to pumping in the glacial and Silurian units cause almost no change to flux conditions along the model boundaries, justifying the use of fixed head boundary conditions.

\section{Objectives of the Kettle Moraine Springs (KMS) Model}

The KMS model was designed to support an analysis of optimal pumping well locations and rates in the shallow aquifer system under long-term average (that is, steady-state) conditions. The optimal system maximizes water supply from the shallow aquifer system to the hatchery operations subject to constraints on water levels, drawdown, and changes to groundwater discharge to surface-water features. The KMS model is designed to perform optimization simulations for both the glacial and Silurian aquifers; however, in this report, only simulations of pumping scenarios involving the Silurian aquifer are analyzed (appendix 6). 


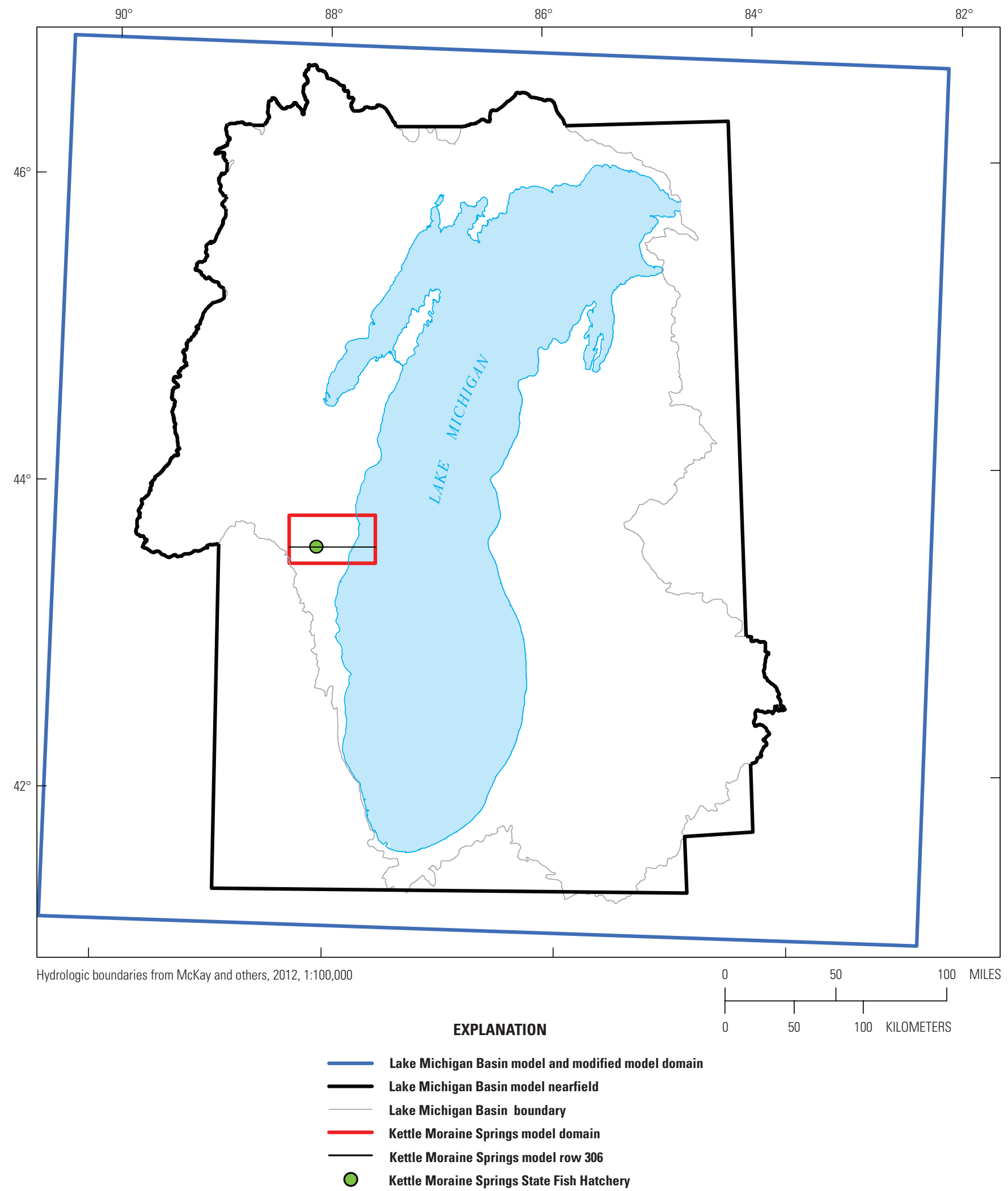

Figure 4-1. Extent of Kettle Moraine Springs (KMS) model domain extracted from regional Lake Michigan Basin (LMB) model. 


\section{Model Layering and Refinement of Land Surface and Bedrock Surface}

The model layering for the local KMS model was inherited from the 20-layer regional LMB model (Feinstein and others (2010); however, layers representing hydrostratigraphic units that are not present in the KMS model domain (for example Pennsylvanian- and Mississippian-age units found east of Lake Michigan) have been removed. As a result, the inset model contains 14 layers representing nine hydrostratigraphic units; the names have been revised slightly to conform to the stratigraphic nomenclat1-3ure of the Wisconsin Geological and Natural History Survey (2011).

\begin{tabular}{lc} 
Unit & Layers \\
\hline Glacial aquifer/confining unit & $1-3$ \\
Silurian aquifer unit & $4-6$ \\
Maquoketa confining unit & 7 \\
Sinnipee aquifer/confining unit & 8 \\
Ancell Group-St. Peter aquifer unit & 9 \\
Prairie du Chien-Trempealeau Groups aquifer/confining unit & 10 \\
Elk Mound Group - Ironton-Galesville aquifer unit & 11 \\
Elk Mound Group - Eau Claire aquifer/confining unit & 12 \\
Elk Mound Group - Mount Simon aquifer unit & $13-14$
\end{tabular}

The layering logic is presented in table 3 of Feinstein and others (2010). The scheme used for the glacial and Silurian deposits is of central importance to the current applications. Layer 1 consists of unconsolidated glacial (and alluvial) deposits that extend from the land surface to a maximum depth of $100 \mathrm{ft}$. If more than $100 \mathrm{ft}$ of glacial deposits are present, layer 2 extends from a depth of $100 \mathrm{ft}$ to a maximum depth of $300 \mathrm{ft}$. If more than $300 \mathrm{ft}$ of glacial deposits are present, layer 3 extends from a depth of $300 \mathrm{ft}$ to the bedrock surface. Typically, glacial deposits in the KMS model domain were not more than $300 \mathrm{ft}$ thick; therefore, layer 3 in the inset model is assigned a "pinched" thickness of $0.2 \mathrm{ft}$ in most places. Where the glacial deposits were not more than $100 \mathrm{ft}$ thick, then both layers 2 and 3 were pinched. Layer 4 represents the upper and, what is assumed to be, more weathered part of the Silurian dolomite bedrock and extends from the bottom of glacial layer 3 to a maximum depth of $50 \mathrm{ft}$. Where the Silurian bedrock is greater than $50 \mathrm{ft}$ (everywhere in the local domain), layer 5 typically represents the remaining thickness. In limited areas of the KMS model domain, the thickness is very large (greater than $550 \mathrm{ft}$ ), and the lower part of the Silurian bedrock unit is included in layer 6 . This is due to the logic of the layering approach of the original LMB model (Feinstein and others, 2010).

The top and bottom surfaces for the COAS part of the flow system (layers 7-14) were inherited from the regional LMB model and reflect the regional 5,000-ft grid spacing (fig. 4-2). However, the surfaces that define the shallow system have been revised based on digital elevation datasets (Gesch and others, 2002) and well construction logs (Wisconsin Department of Natural Resources, 2016) consistent with the 250 -ft grid spacing of the local KMS model. After the application of a kriging process to the new data, the tops and bottoms of the layers constituting the glacial and Silurian units (layers 1-6), appear smoother than the deeper units. The example presented in figure 4-3 is the surface of model layer 4, the top of the Silurian bedrock. The cross section in figure 4-4 shows the updated thickness of the shallow (glacial and Silurian) units and the inherited thickness of the deep (Maquoketa and Cambrian-Ordovician) units along an east-west section that intersects the hatchery property. The model representation of the land surface altitude, thickness of glacial deposits, altitude of the bedrock (top of Silurian dolomite) surface, and thickness of Silurian dolomite are shown for much of the KMS model domain in figures 4-5 through 4-8.

\section{Updated Aquifer Properties and Boundary Conditions to the Kettle Moraine Springs (KMS) Model}

\section{Distribution of Hydraulic Conductivity in Glacial Deposits}

The recent glacial geologic history in eastern Wisconsin is dominated by a series of glacial advances and retreats. The surficial deposits in this area are derived from two glacial lobes, one depositing relatively coarse-grained deposits and the other depositing relatively fine-grained deposits (fig. 2). Within the KMS model, domain is the transition from the area dominated by silt- and clay-rich tills associated with the Lake Michigan lobe to the east to a variety of deposits containing appreciable fractions of sand and gravel associated with the Green Bay Lobe to the west. The hatchery property is within and near the eastern boundary of the Green Bay Lobe.

For most of the KMS model, the horizontal and vertical hydraulic conductivity values assigned the glacial material were inherited from the LMB model. However, for the area in the vicinity of the hatchery (denoted as the "local area" of the KMS model and shown in fig. 4-2), the glacial hydraulic conductivity values were updated to better reflect the glacial depositional pattern at the inset model's finer grid scale. Two sources of information were harnessed to update the distribution of values:

- Sediment descriptions from well completion reports compiled by the Wisconsin Department of Natural Resources (2016), and

- The glacial units (till, outwash, alluvial, and organic deposits) mapped by the Wisconsin Geological and Natural History Survey (Carlson and others, 2011). 
A. Model row 306 cross section, no vertical exaggeration

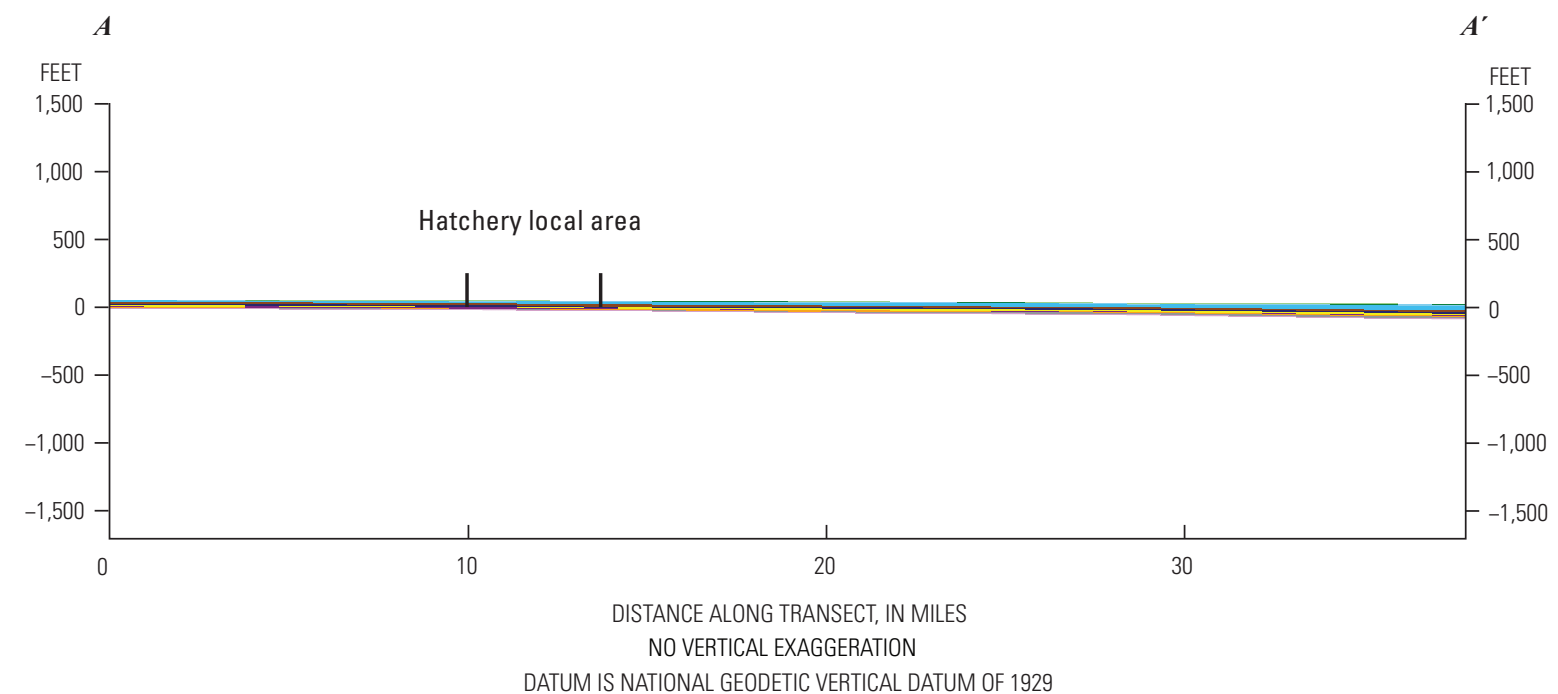

B. Model row 306 cross section, vertical exaggeration=20X

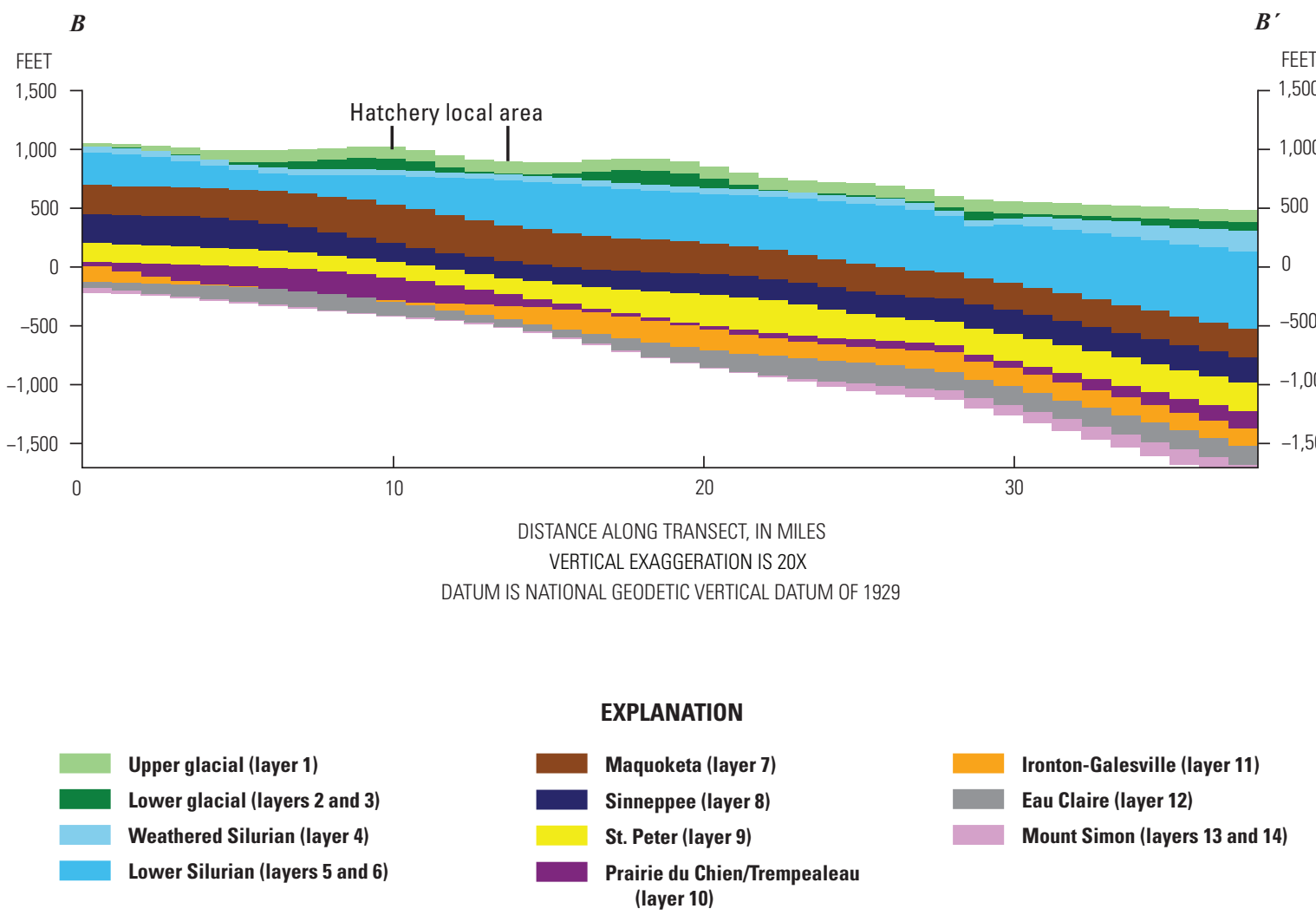

Figure 4-2. East-west cross section showing hydrostratigraphy of inset Kettle Moraine Springs (KMS) model derived from the parent Lake Michigan Basin (LMB) model: $A$, exhibits no vertical exaggeration, and $B$, exhibits $20 x$ vertical exaggeration. 


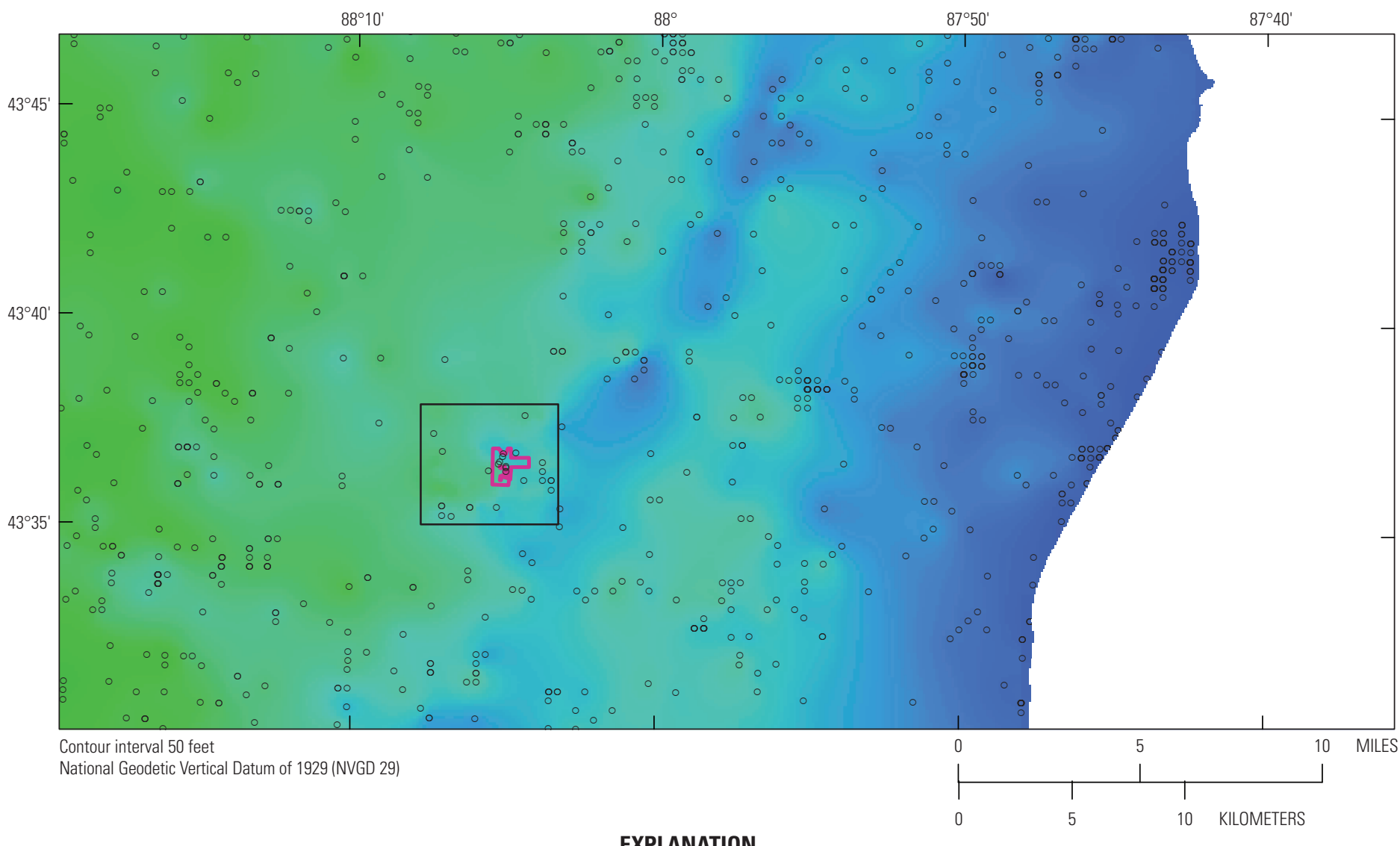

\section{EXPLANATION}

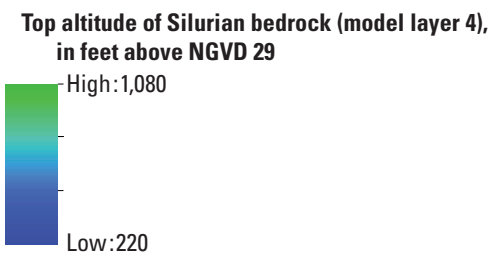

Kettle Moraine Springs State Fish Hatchery

- Local model area

Wells used in bedrock surface altitude interpolation

Figure 4-3. The Silurian bedrock surface within the Kettle Moraine Springs (KMS) model domain after refinement using a kriging process applied to stratigraphic data derived from well construction reports. 


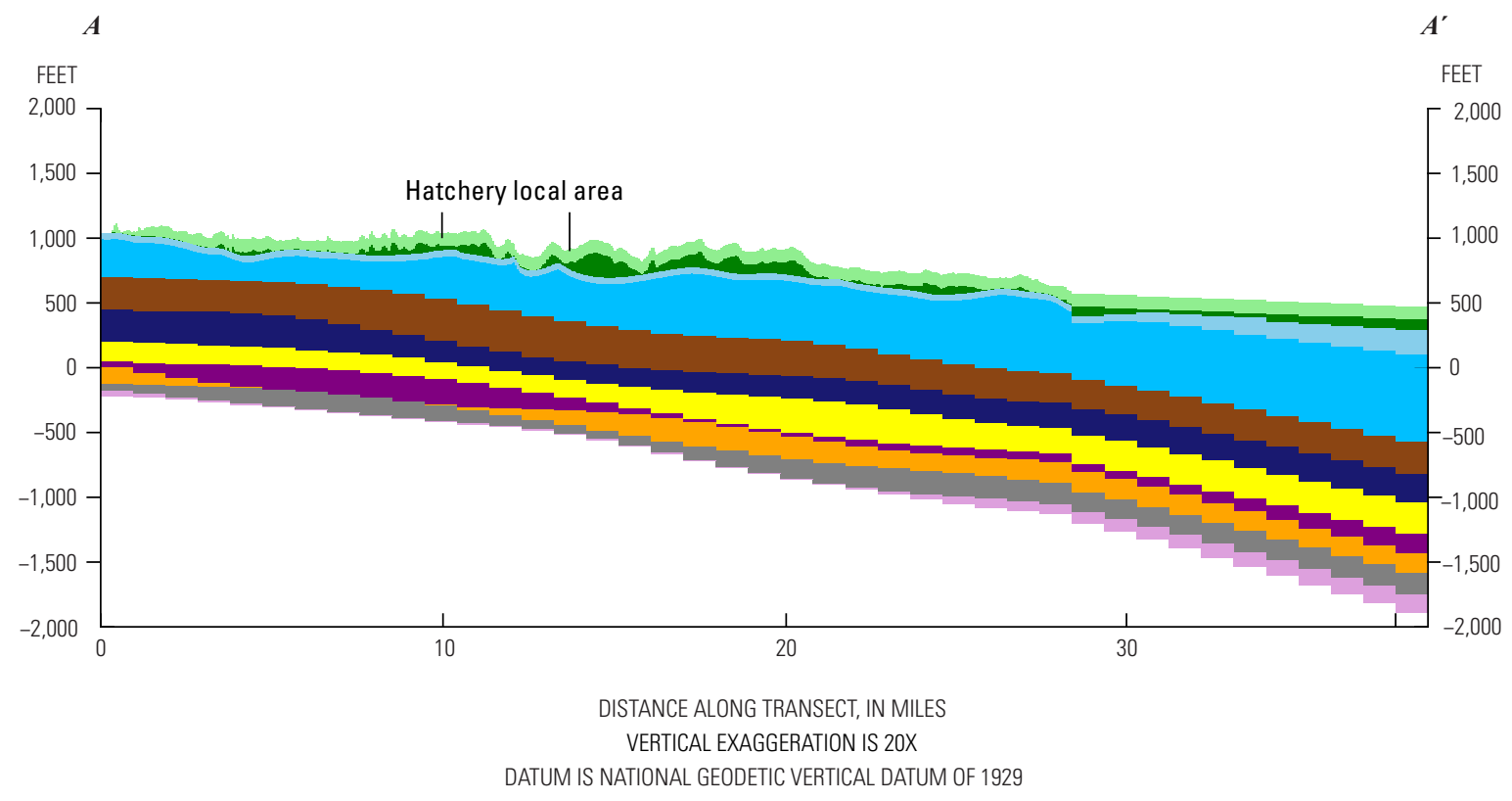

Upper glacial (layer 1)

Lower glacial (layers 2 and 3 )

Maquoketa (layer 7)

Sinneppee (layer 8)

St. Peter (layer 9)

Ironton-Galesville (layer 11)

Weathered Silurian (layer 4)

Prairie du Chien/Trempealeau

(layer 10)

Figure 4-4. East-west cross section showing updated model layers 1-6 after refinement of land surface and Silurian bedrock surface. Layering of the deeper layers are inherited from the Lake Michigan Basin (LMB) model (Feinstein and others, 2010). 


\section{A}

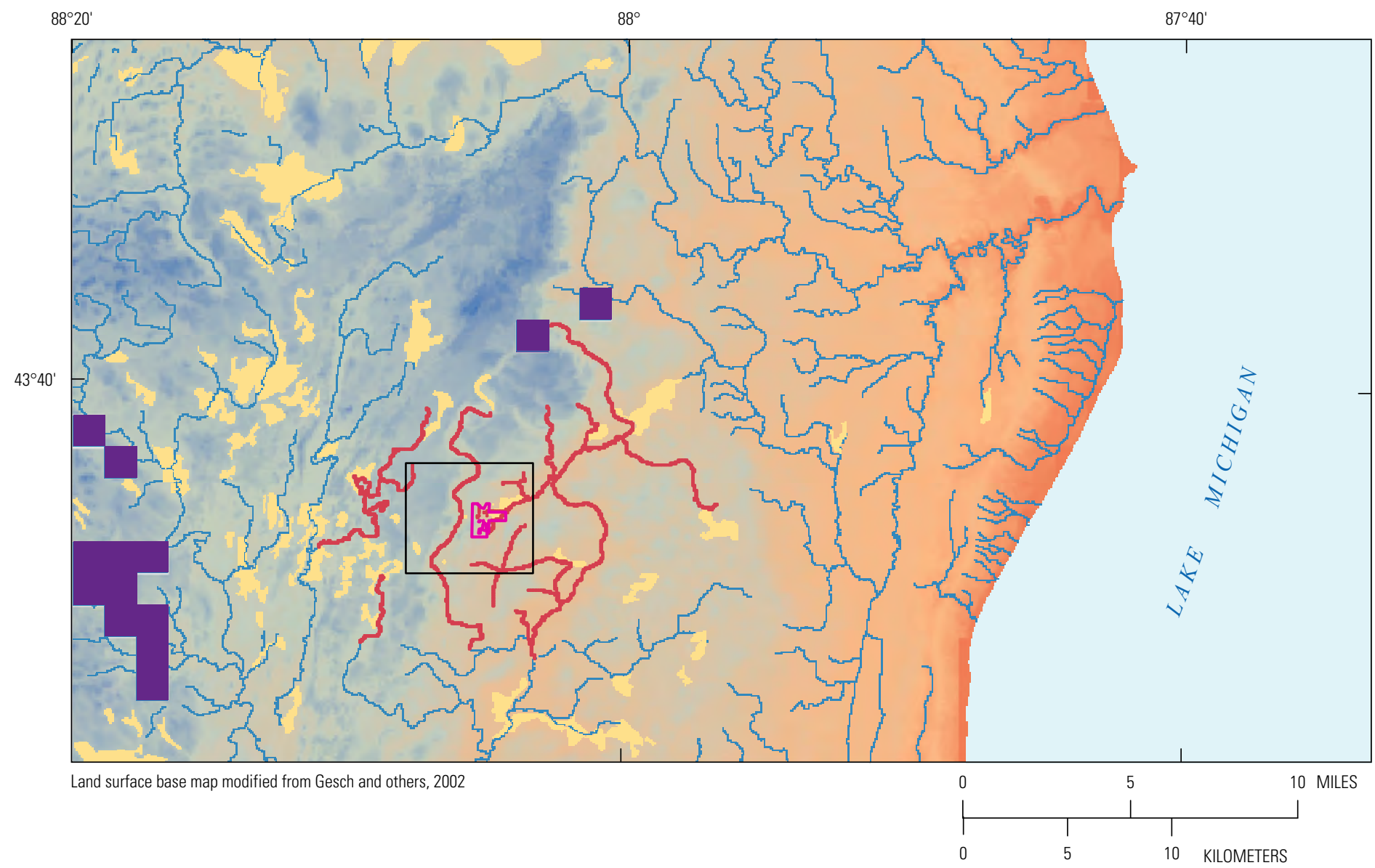

EXPLANATION
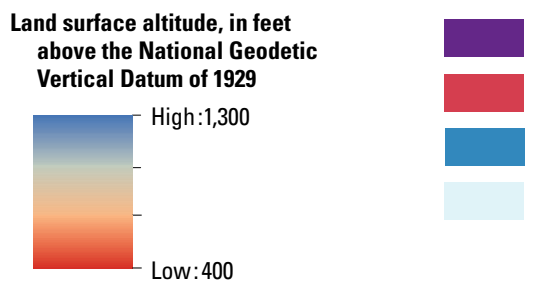

No flow cells

Drain cells

Stream cells

Local area

River cells

Kettle Moraine Springs

General head boundary

State Fish Hatchery

representing Lake Michigan

Figure 4-5. Land surface altitude for $A$, the Kettle Moraine Springs (KMS) model domain and $B$, a smaller local area that includes the Kettle Moraine Springs State Fish Hatchery, Sheboygan County, Wisconsin. 
$\boldsymbol{B}$

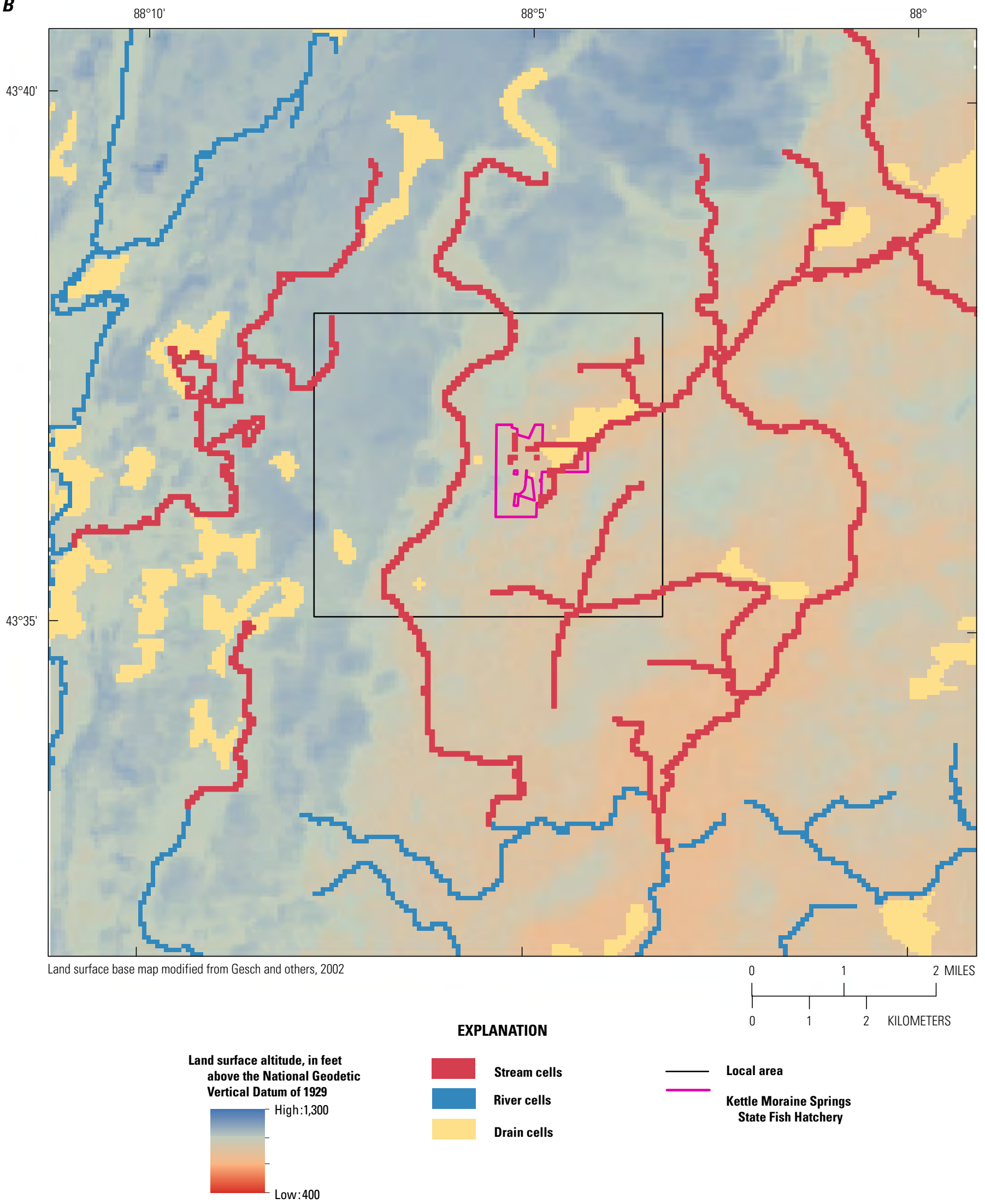

Figure 4-5. Land surface altitude for $A$, the Kettle Moraine Springs (KMS) model domain and $B$, a smaller local area that includes the Kettle Moraine Springs State Fish Hatchery, Sheboygan County, Wisconsin.-Continued 


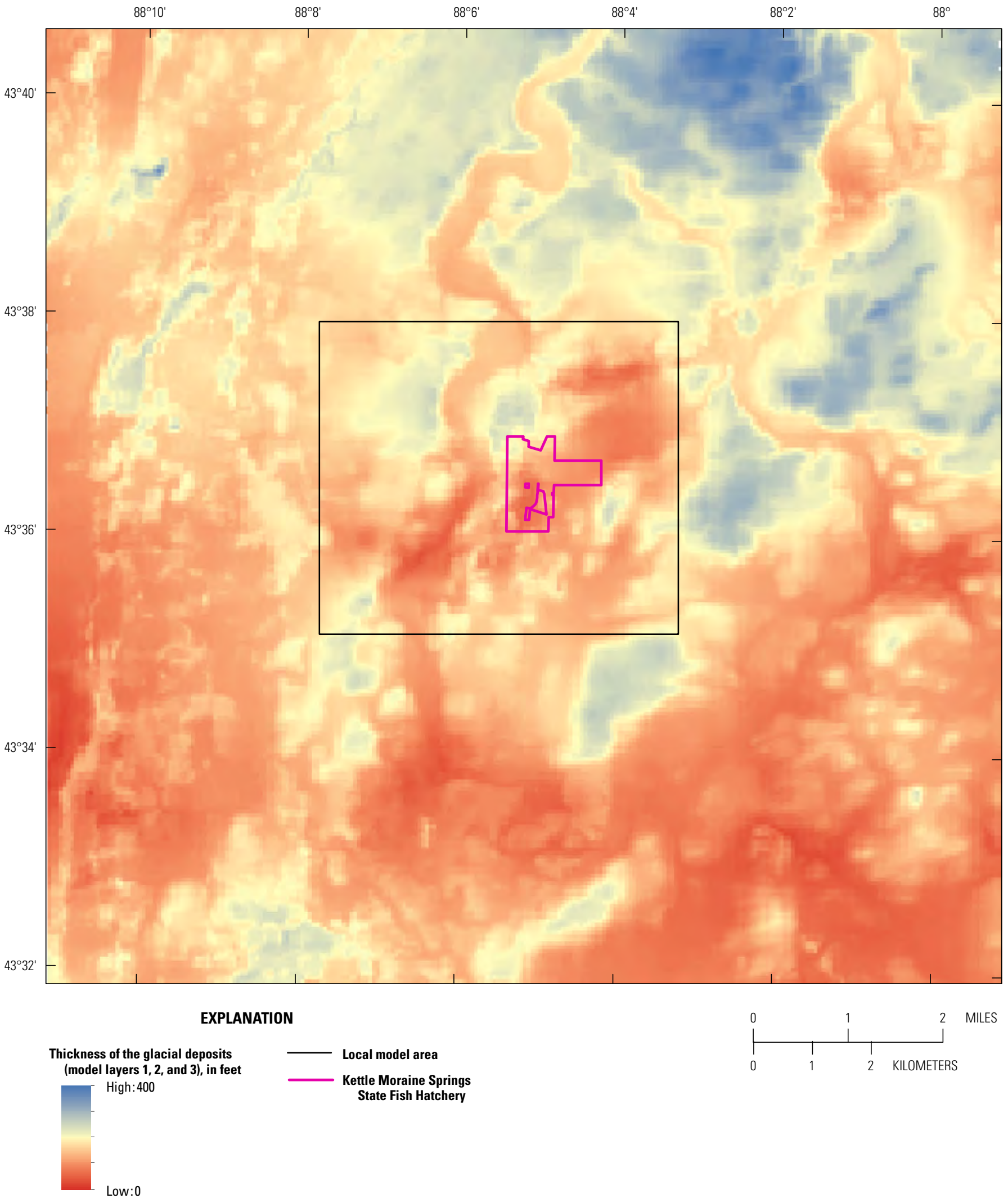

Figure 4-6. Thickness of glacial deposits in an area that includes the Kettle Moraine Springs State Fish Hatchery, Sheboygan County, Wisconsin. 


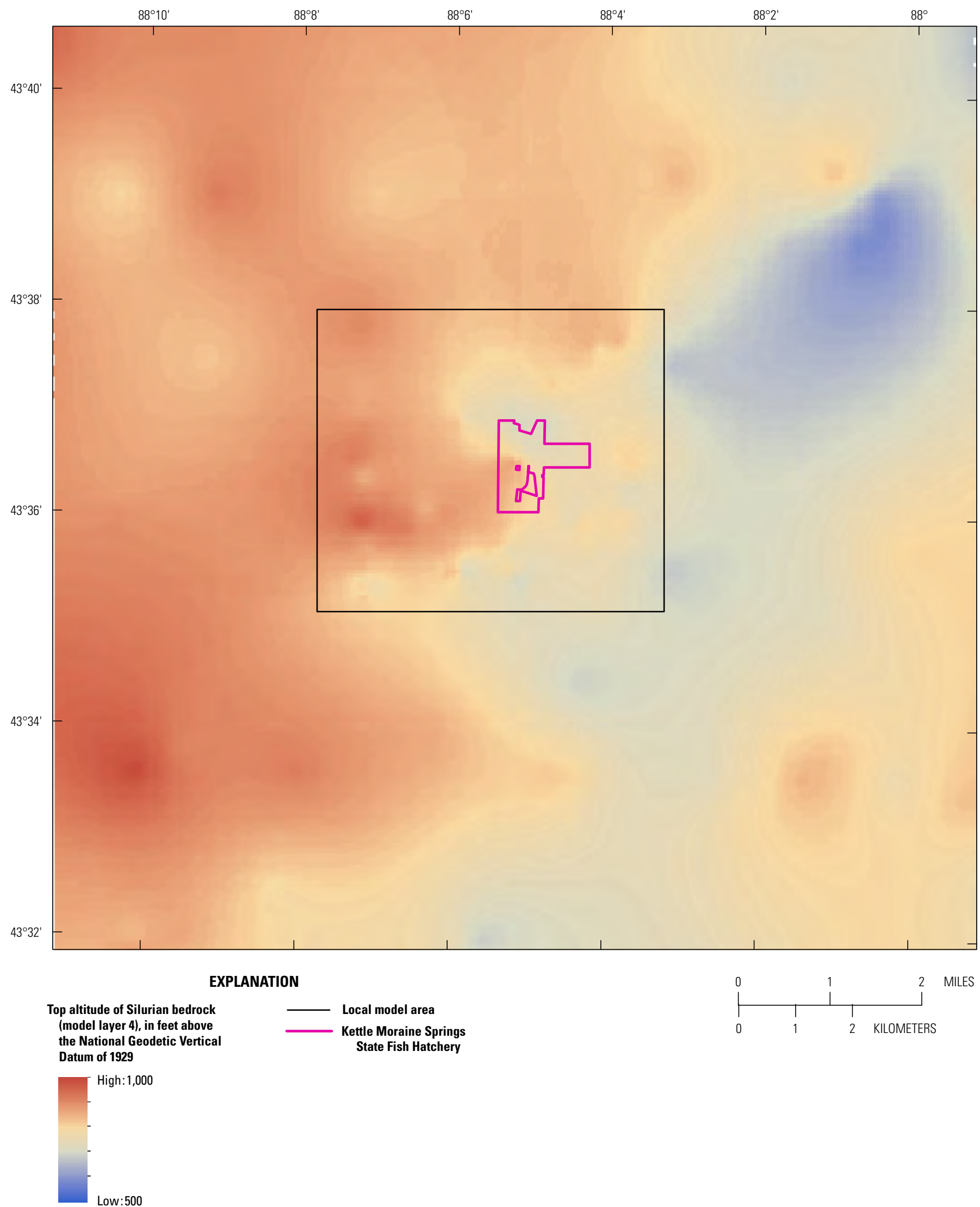

Figure 4-7. Bedrock surface (top of Silurian aquifer) in an area that includes the Kettle Moraine Springs State Fish Hatchery, Sheboygan County, Wisconsin. 


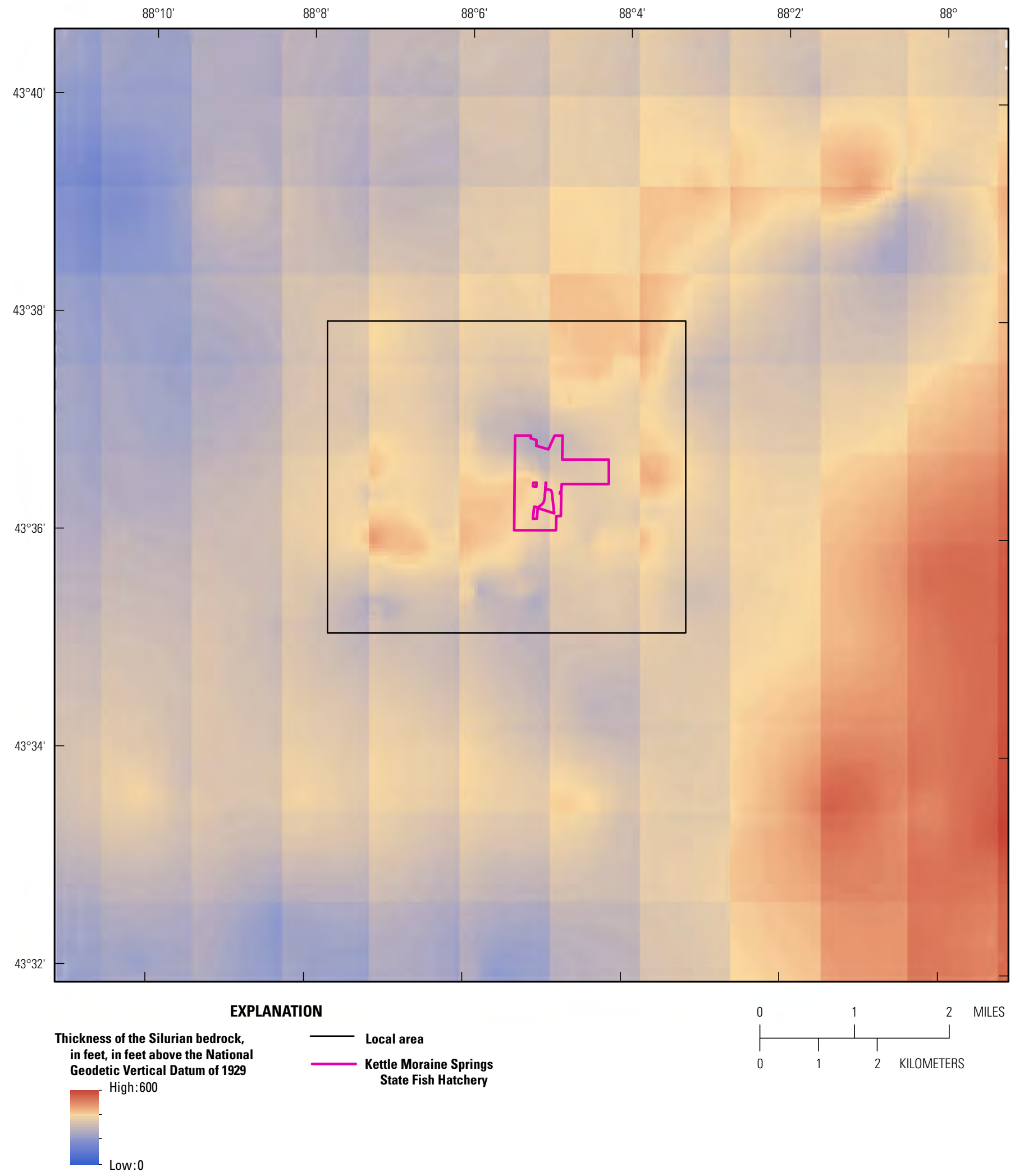

Figure 4-8. Thickness of the Silurian aquifer in an area that includes the Kettle Moraine Springs State Fish Hatchery, Sheboygan County, Wisconsin. 
The method used for combining these two data sources to estimate hydraulic conductivity is very similar to the method outlined in appendix 3 in Feinstein and others (2010) and Juckem and others (2016). In brief, lithologic descriptions from the well construction reports are sorted into one of four texture categories, each of which is assigned a coarse fraction representative of the material type. The depth intervals of these textural categories are intersected with the model layering so that the coarse fraction assignments can vary with depth in layers 1 and 2 (layer 3 is pinched in the local area around the hatchery). A coarse fraction is assigned to each model cell in each layer by interpolating values between the well locations using kriging and an exponential variogram fitted to the data. The coarse fraction assigned to a cell is converted to a horizontal hydraulic conductivity value based on a distinct power law for each glacial mapped unit represented in Carlson and others (2011) (fig. 4-9). The sediments represented in the mapped units are diamicton, gravel, sand, and organics associated with marsh areas. The power laws incorporate a minimum, expected, and maximum value of horizontal hydraulic conductivity that are matched with the minimum, mean, and maximum coarse fractions computed for each glacial unit. The hydraulic conductivity values applied to each power law equation were based on values obtained from the regional LMB model (Feinstein and others, 2010). These values correspond to the type of material; they are relatively low for diamicton and relatively high for gravel and gravel/sand. The vertical hydraulic conductivity was set everywhere to $1 / 40$ th the value of the horizontal hydraulic conductivity assigned a cell, based on the average vertical anisotropy value yielded by the calibration of the regional LMB model.

The horizontal hydraulic conductivity $\left(\mathrm{K}_{\mathrm{h}}\right)$ distributions generated by the power laws in the local area around the hatchery show a fair amount of variation for model layers 1 and 2. The average value in the local area around the hatchery is $94 \mathrm{feet} / \mathrm{day}(\mathrm{ft} / \mathrm{d}$ ) for layer 1 and $54 \mathrm{ft} / \mathrm{d}$ for layer 2, but the range in $\mathrm{K}_{\mathrm{h}}$ was larger for layer $2(2-644 \mathrm{ft} / \mathrm{d})$. The cell-by-cell variation in hydraulic conductivity is subject to a single multiplier applied during the calibration process (discussed below). However, it is worth noting that the method just describedrefining hydraulic conductivity values that are then adjusted based with a single multiplier during calibration to observed water levels and surface-water fluxes-leaves a great deal of uncertainty about the estimated glacial hydraulic conductivity values and distribution given the pronounced amount of heterogeneity from multiple depositional processes (Carlson and others, 2011; Syverson and others, 2011). If one or more pumping tests were performed in the glacial aquifer, followed by focused recalibration of the glacial aquifer, this uncertainty would be reduced, but because the planned well placement in the shallow aquifer system is limited to wells completed in the Silurian aquifer and excludes wells completed in the glacial deposits, the uncertainty in the model representation of the glacial deposits was less consequential for model predictions (appendix 6) than it would be if wells completed in glacial deposits were planned for hatchery water supply.

\section{Distribution of Hydraulic Conductivity in Silurian Aquifer}

The upper $50 \mathrm{ft}$ of the Silurian aquifer, a bedrock unit consisting chiefly of dolomite, was assumed to be more weathered, and therefore more permeable than the underlying rock. A number of studies (Webb, 1989; Mueller, 1992; Dunning and others, 2004) helps to distinguish the value of horizontal and vertical hydraulic conductivity in the shallow and presumably weathered part of the Silurian aquifer from the permeability deeper in the unit. The initial horizontal and vertical hydraulic conductivity values for the upper part (layer 4) and the lower part of the Silurian aquifer (layers 5 and 6) were inherited from the regional LMB model. These inherited values are $10.1 \mathrm{ft} / \mathrm{d}\left(\mathrm{K}_{\mathrm{h}}\right)$ and $0.010 \mathrm{ft} / \mathrm{d}\left(\mathrm{K}_{\mathrm{v}}\right)$ in layer 4 , and $3.4 \mathrm{ft} / \mathrm{d}\left(\mathrm{K}_{\mathrm{h}}\right)$ and $0.005 \mathrm{ft} / \mathrm{d}\left(\mathrm{K}_{\mathrm{v}}\right)$ in layers 5 and 6 . Given the thickness of the Silurian aquifer, the implied transmissivity of the unit is on the order of 1,200-1,700 square feet per day $\left(\mathrm{ft}^{2} / \mathrm{d}\right)$ in the local area around the hatchery property. The upper end of this precalibration value is somewhat greater than the $1,220 \mathrm{ft}^{2} / \mathrm{d}$ transmissivity derived from a pumping test conducted by the USGS on a well completed in the Silurian aquifer and located on the hatchery grounds (Conlon, 1995).

Like the glacial hydraulic conductivity values, these initial Silurian values assigned to the KMS model are subject to variation during calibration. In contrast, the hydraulic conductivity values inherited from the regional LMB model and assigned to the underlying bedrock layers (the Maquoketa Shale and the COAS) are held fixed during calibration. This was because the Maquoketa Shale is present over the entire KMS model domain and is an effective confining unit separating the groundwater-flow system into the shallow aquifer system (glacial and Silurian aquifers) and the deep system (COAS). As a result, just as the response to stresses in the deep system have only a small effect on the shallow aquifer system (appendixes 2 and 3), the response to stresses like pumping in the shallow system have only a small effect on the deep system. For this reason, it is not necessary to update the parameters assigned to the deep aquifer system as part of the development of the local KMS model dedicated to evaluating water availability in the shallow units.

\section{Surface-Water Input}

The surface-water system is another important set of inputs to the KMS model. Streams, lakes, ponds, wetlands, marshes, and springs are internal boundary conditions to the groundwater-flow system. These features serve both as discharge areas for groundwater and as sources of water to pumping wells (either because water that would discharge to surface water is captured instead by wells or because water is directly induced from surface water by pumping.). The KMS model is designed to only simulate base-flow conditions (that is, to simulate only the groundwater component of streamflow and to ignore the overland flow or storm component that 


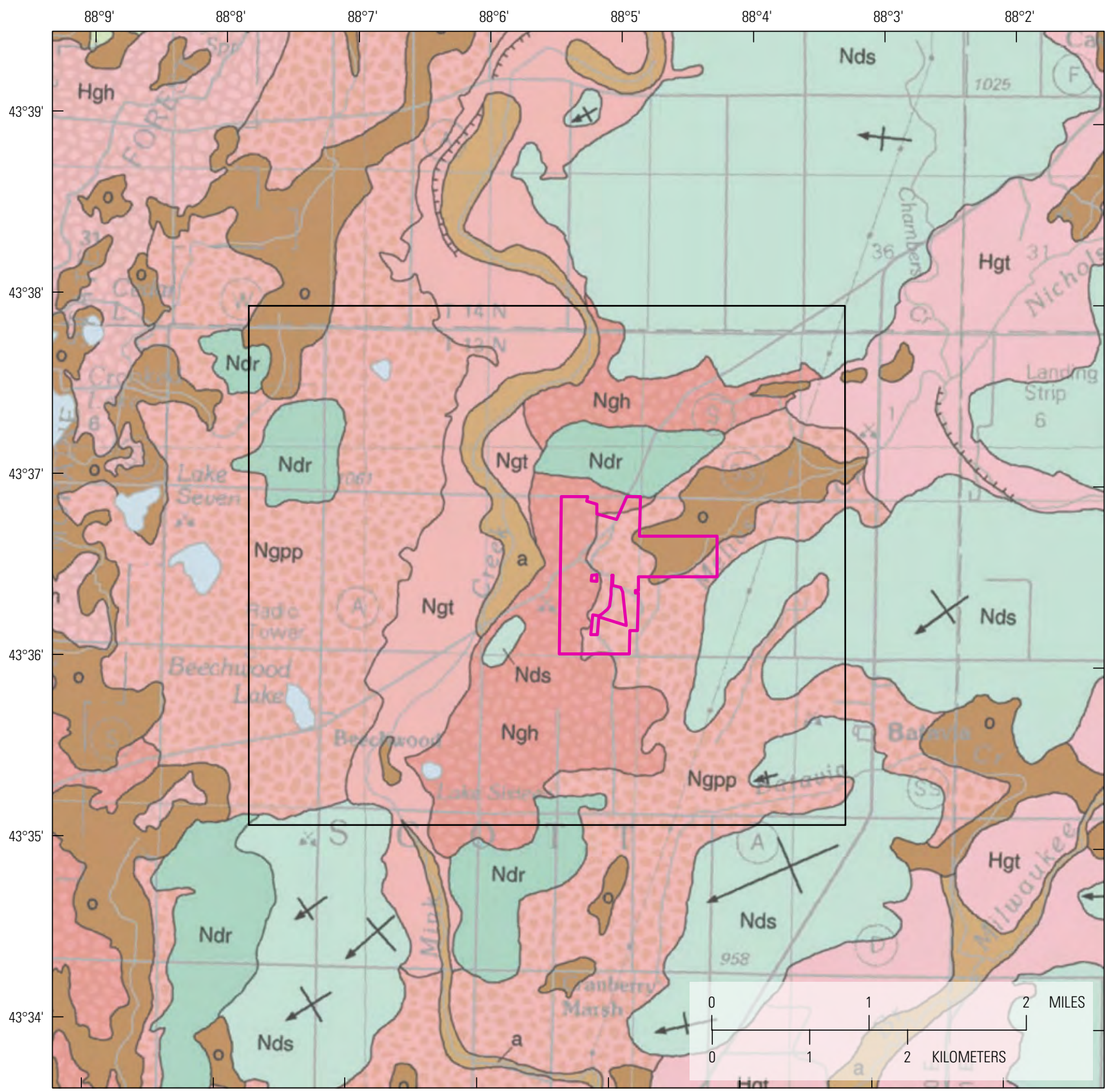

Wisconsin Transverse Mercator Projection1991 adjustment to the North American Datum of 1983 (NAD 83/91). The base map was constructed from U.S. Geological Survey digital line graph files (1990, scale 1:100,000 and modified by the Wisconsin Department of Natural Resources (1992) and the Wisconsin Geological and Natural History Survey (2004).

\section{EXPLANATION}

Stratigraphic unit -Full description of the glacial deposits, Carlson and others (2011)

a Postglacial sand and silt. Commonly a mix of sand, silt and clay, and variable amounts of organic matter. Alluvium

0 Postglacial organic sediment. Peat and muck

$\mathrm{Ndr}$ New Berlin Member, diamicton, gravelly, clayey, silty sand, crudely stratified, or unstratified, rolling topography

Nds New Berlin Member, diamicton, gravelly, clayey, silty sand, crudely stratified, or unstratified. Streamlined forms produced by sliding at the glacial bed
Ngpp New Berlin Member, gravel and sand in pitted outwash plains. Gravel deposited by braided streams in front of glacier margin

Ngh New Berlin Member, gravel and sand in areas of hummocky topography

Ngt New Berlin Member, gravel and sand in outwash terraces

Hgt Undifferentiated deposits of gravel and sand in outwash terraces

Hgh Undifferentiated deposits of gravel and sand in areas of hummocky topography

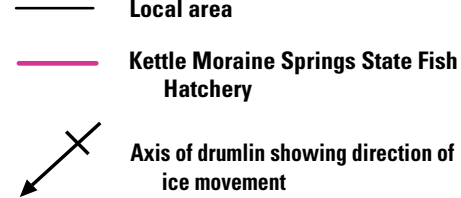
ice movement

Figure 4-9. Quaternary geology of the local area around the Kettle Moraine Springs State Fish Hatchery, Sheboygan County, Wisconsin. 
swells streamflow during the wetter times of the year) and so is considered conservative from the standpoint of protecting streams in the presence of pumping (appendix 6).

Because of its refined grid spacing, surface-water features are more accurately represented in the KMS model than in the regional LMB model (fig. 4-10). The features are represented by different MODFLOW packages with different functions. Throughout the model domain, water bodies such as lakes, ponds, wetlands, and marshes are represented by the MODFLOW DRN (drain) package, and accordingly act only as discharge features in the model solution (meaning they are only active if the simulated water table has a higher altitude than the altitude of the drain itself). Water bodies may be perched above the water table; in which case, it is important that such features not participate in the groundwater-flow solution. Streams are generally not perched and thus are treated differently in the model. Over the farfield of the domain, streams are represented by the MODFLOW RIV (river) package, and accordingly act as a groundwater sink if the simulated water table is above the prescribed stream altitude and as a groundwater source if the water table is below the stream altitude. The RIV cells are only used in the farfield because of an important limitation - a reach of stream represented by a RIV cell where the stream altitude is above the simulated water table becomes a potentially unlimited source of water. In such a situation, the RIV cell can provide water to the groundwater system (for example, under the influence of a nearby shallow pumping well) even if base-flow conditions are such that the simulated reach was dry. Because it is possible that the use of the RIV package might overestimate the ability of a stream to act as a source of water to supply wells, the alternative MODFLOW SFR (streamflow routing) package has been used in the vicinity of the hatchery (fig. 4-10). This package keeps track of the available base flow in stream channels and limits stream losses to the amount of simulated base flow available in the stream. The input to the SFR package is more intensive than the RIV package (the connections between stream reaches associated with model cells and the channel geometry must be explicitly specified), but it is important to use the SFR package in areas where it is possible that pumping will reverse natural gradients and actually draw water directly from a stream. One of these streams, Melius Creek, crosses the hatchery property and also abuts a marsh (represented by the DRN package) that is prominent in the northern part of the local area around the hatchery.

Another prominent set of features represented in the KMS model are the springs around the hatchery property (fig. 4-11). A large amount of the local groundwater discharge occurs at the springs in the western and northwestern parts of the hatchery grounds along uplands consisting mostly of coarse-grained glacial material. Some springs in the hatchery area are in their natural state, but the springs providing water to the hatchery have been altered with constructed spring boxes that concentrate the flow and transport water for hatchery use via underground pipes and is used in operations before being discharged to Melius Creek. In the KMS model, the local springs are represented by SFR reaches so that, where appropriate, the discharge can be routed to downgradient surface-water features. In this way, the effect of pumping on the spring discharge and downgradient routed flow can be directly evaluated.

The input to the SFR package for streams consists of

- The top of streambed for each cell reach, which is set from the minimum land surface in the cell contained in the Digital Elevation Dataset for this area (Gesch and others, 2002; U.S. Geological Survey, 2016a);

- The width of the stream, which is set to $10 \mathrm{ft}$ for all reaches;

- The length of the reach in each cell, which is calculated by overlaying the model grid on the U.S. Geological Survey National Hydrography Database for this area (U.S. Geological Survey, 2016b);

- The thickness of the streambed, which is set to $1 \mathrm{ft}$ for all reaches;

- The vertical hydraulic conductivity of the streambed, which is set to $5 \mathrm{ft} / \mathrm{d}$ for all reaches;

- The slope of the streambed, which is set to $0.001 \mathrm{ft} / \mathrm{ft}$ for all reaches; and

- The Manning roughness coefficient of the streambed, which is set to $0.037 \mathrm{~d} / \mathrm{ft}^{1 / 3}$ for all reaches, a typical value for moderately rough channel (Barnes, 1967).

The slope of the streambed and the Manning roughness coefficient are used in conjunction with the other inputs and the base-flow solution to compute the depth of water in each reach. All the values assigned the streams, including the vertical hydraulic conductivity of $5 \mathrm{ft} / \mathrm{d}$ assigned to the streambed, are kept constant during the calibration process.

The input to the SFR cells representing springs differs from input to stream cells in that the properties of the bed material in contact with the spring is an engineered medium rather than natural sediments. The area of each spring bed is assumed to be the size of the cell it occupies ( $250 \mathrm{ft}$ by $250 \mathrm{ft}$ ), and the material thickness is assumed to be equal to $1 \mathrm{ft}$. The vertical hydraulic conductivity of the spring boxes is difficult to estimate. The initial values for all spring cells is set to about $0.01 \mathrm{ft} / \mathrm{d}$, but this value is varied for each cell or cells associated with a group of springs during the calibration process.

\section{Water-Use Input}

Pumping wells act as sinks for groundwater in both the shallow and deep systems of the KMS model domain. The wells represented in the KMS model come from a database of historical high-capacity wells pumping from the Lake Michigan Basin (Buchwald and others, 2010), with the addition of newly constructed high-capacity wells and previously unaccounted for low-capacity wells that withdraw more than 1 


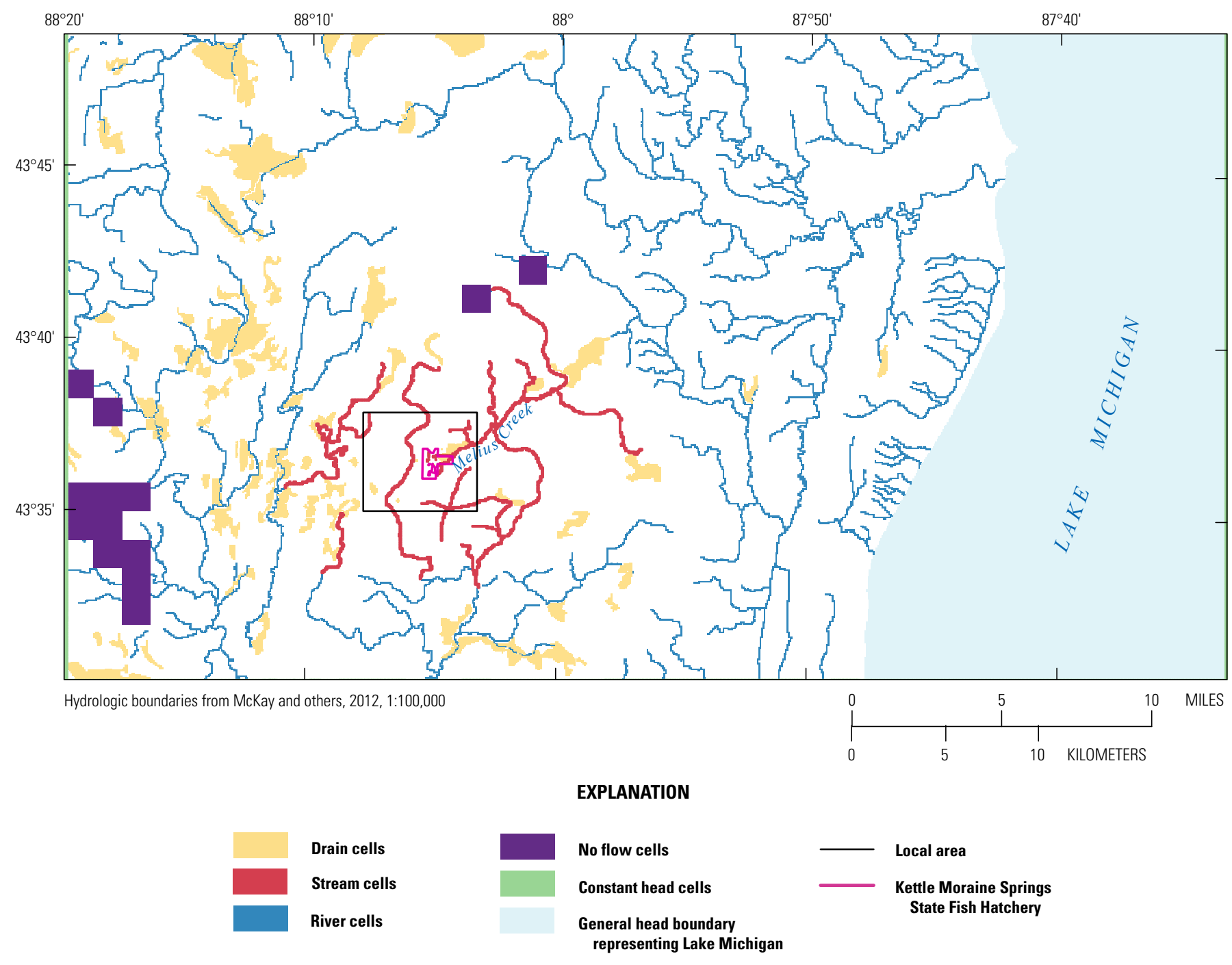

Figure 4-10. Representation of surface-water features in the Kettle Moraine Springs (KMS) model, Sheboygan County, Wisconsin. 


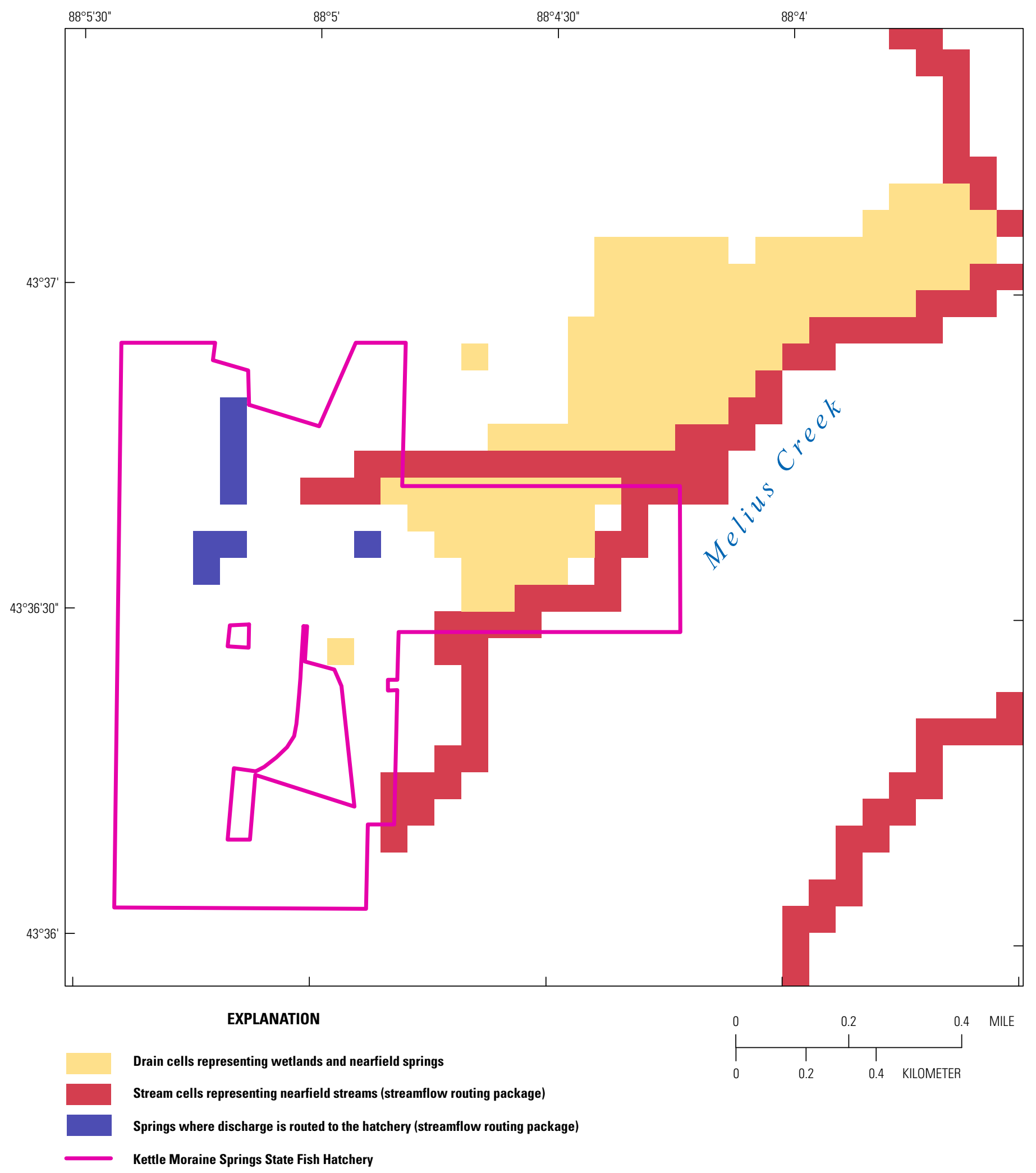

Figure 4-11. Representation of surface-water features in and around the Kettle Moraine Springs State Fish Hatchery as represented in the Kettle Moraine Springs (KMS) model, Sheboygan County, Wisconsin. 
million gallons per year from a single property. For those wells for which that information was missing in the Lake Michigan Basin model database, well logs and well construction reports were reviewed to determine the source aquifer system. Pumping rates were updated to 2012 and reflect average "present" conditions, which is typically the average of available reported data between 2007 and 2012. Updated withdrawal rates are primarily from reported water-use data of the Wisconsin Department of Natural Resources (WDNR), Wisconsin Public Service Commission, and KMSSFH operation reports. Almost 90 percent of the 7.6 million gallons per day (Mgal/d) pumpage represented in the KMS model domain is associated with public supply or industrial and aquaculture enterprises. By volume, nearly half of the water withdrawn (47 percent) within the KMS model domain is used for public supply (fig. 4-12). Locations for wells represented in the model are shown in figure 4-13, distinguished by their completion in the glacial aquifer, the Silurian aquifer, or the CambrianOrdovician aquifer. The 6 glacial wells ( 2 are obscured by Silurian wells in the figure) pump a total of $0.80 \mathrm{Mgal} / \mathrm{d}$, the 113 high-capacity wells in the Silurian aquifer pump a total of $5.67 \mathrm{Mgal} / \mathrm{d}$, and the 4 wells in the Cambrian-Ordovician aquifer (2 are virtually co-located in the figure) wells pump a total of $0.30 \mathrm{Mgal} / \mathrm{d}$. In addition to well withdrawals, springs of the KMSSFH remove $0.82 \mathrm{Mgal} / \mathrm{d}$ from the groundwater system. It is also worth noting that the pumping from the COAS in Sheboygan County, where the hatchery resides, is small compared to the pumping in counties to the south and west where the Cambrian-Ordovician units are more targeted as sources of water supply.

The representation of pumping in the KMS model is more sophisticated than its representation in the regional LMB model. The locations of wells are more accurate because of the refined grid spacing. Multilayered wells are represented as single pumping entities owing to the substitution of the MODFLOW MNW2 (multi-node well) package for the WEL (well) package. Multilayered wells are common in the KMS model because the glacial, Silurian, and Cambrian-Ordovician aquifer systems each span multiple model layers. The MNW2 package solves not only for the effect of pumping on the average water levels at the center of grid cells but also the altitude of the water level inside the well as a function of (1) the cone of depression within the cells penetrated by the well (the socalled "aquifer loss"), and (2) the effect of the disturbed zone around the open interval of the well (the so-called "wellbore skin"). The ability to simulate the borehole water level of candidate Silurian hatchery wells relative to available borehole drawdown was a critical element for assessing water availability for this study.

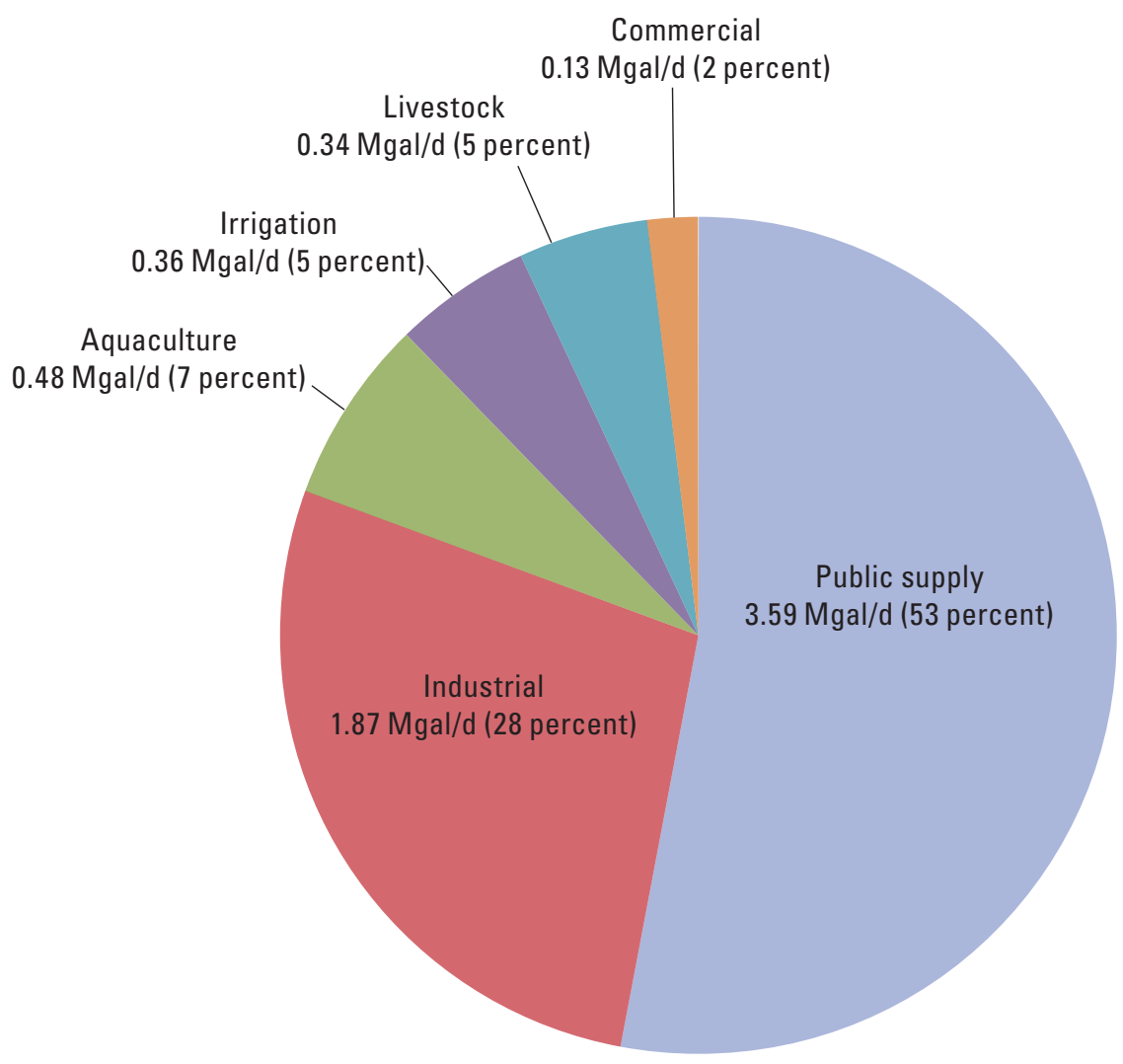

Figure 4-12. Groundwater withdrawals, by category, within the Kettle Moraine Springs model domain, Sheboygan County, Wisconsin, exclusive of residential withdrawals. Withdrawals from 2007 to 2012 were averaged. (Mgal/d, million gallons per day) 


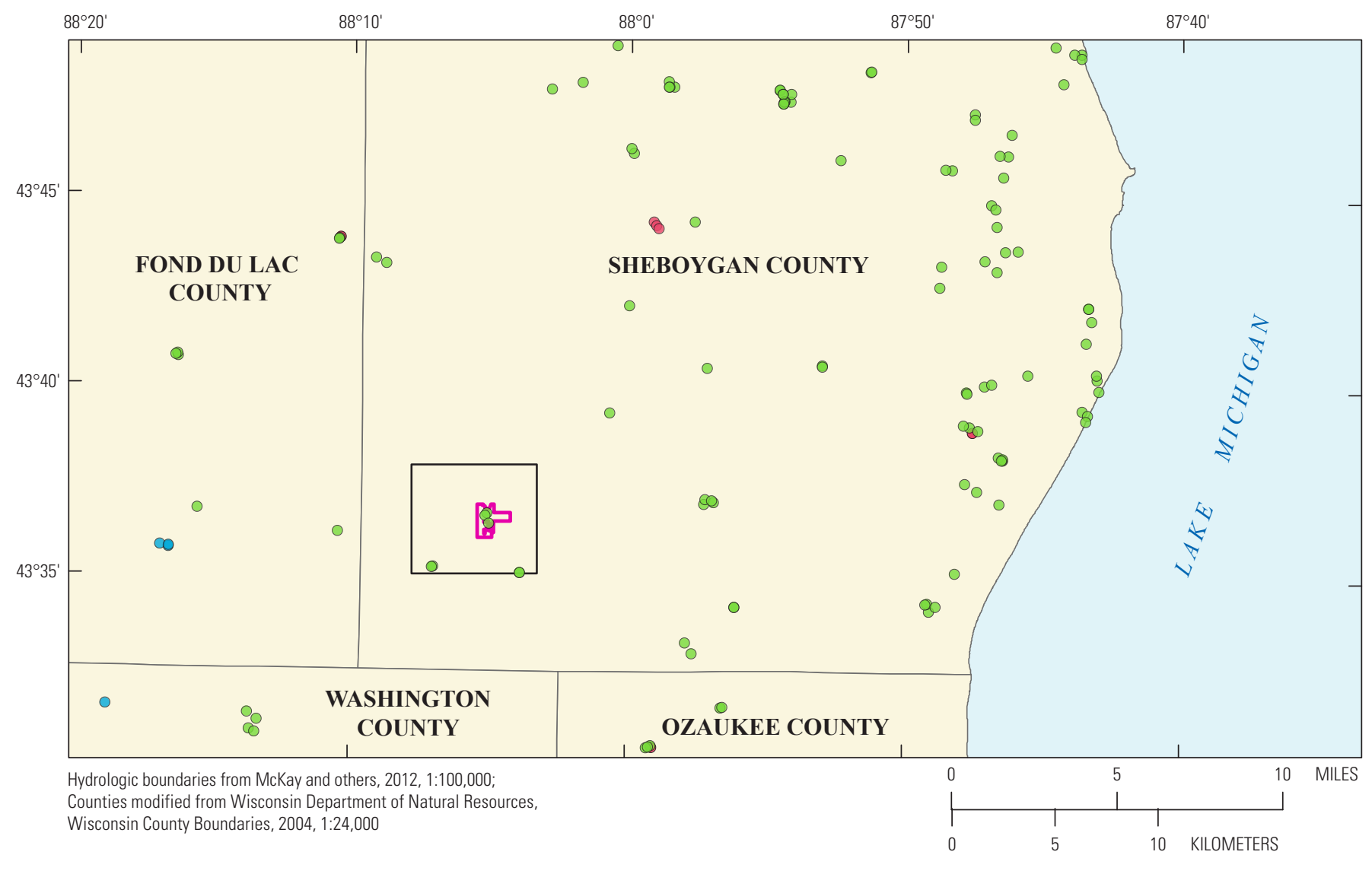

EXPLANATION
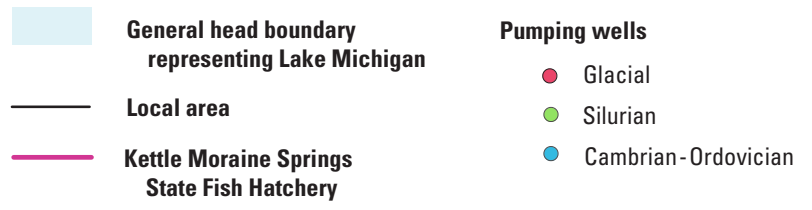

Figure 4-13. Well locations within the Kettle Moraine Springs (KMS) model domain that are actively pumping for the model simulations, Sheboygan County, Wisconsin. 
For all existing wells in the KMS model domain, the wellbore skin is assumed to occupy an annular space extending $0.5 \mathrm{ft}$ beyond the borehole face, and the effective hydraulic conductivity of the skin was set to about 0.4 times the hydraulic conductivity of the surrounding aquifer. The true permeability of the skin is unknown for any given well, but its effect on the simulated borehole water level is only important for project objectives in relation to the candidate hatchery water-supply wells. These candidate wells are not part of the base model but are added to the scenario versions of the model discussed in appendix 6 .

\section{Recharge Input}

Recharge to the water table is the major source of water to the groundwater system.. The amount of recharge to any model row and column location is largely dependent on the rate of infiltration from precipitation and snowmelt across the land surface, followed by the rate of percolation through the unsaturated zone. Recharge in light of these processes can be computed for each cell of the model by using a ThornthwaiteMather Soil-Water-Balance model (SWB) (Westenbroek and others, 2010). In this case, the calculations are made across the entire KMS model domain at the scale of the grid $(250 \mathrm{ft}$ on a side) to replace the calculations performed at a grid spacing of $5,000 \mathrm{ft}$ for the regional LMB model.

The input datasets used in support of the KMS SWB model differ from those used for the LMB modeling effort. In particular, the land-use and soils-derived grids have been refined using updated data sources. These datasets include

- Hydrologic soil groups and available water capacity grids, derived from soils data (SSURGO) published by the U.S. Department of Agriculture (2009);

- Flow-direction grid, derived from U.S. Geological Survey digital elevation model (DEM) data (Gesch and others, 2002); and

- Land-use and land-cover grid, derived from the 2006 National Land Cover Database (Fry and others, 2011).

One other significant departure from the method used in the LMB modeling is the source of precipitation and air temperature data. In the LMB effort, thin-plate splines were created for all available daily data from the cooperative stations run by the National Oceanic and Atmospheric Administration. For the KMS model, the source of the precipitation and air temperature data is the Daymet version 2 gridded dataset (Thornton and others, 2014).

The calculated recharge for part of the KMS model domain is presented in figure 4-14. For more information on the SWB method see Westenbroek and others (2010) and Feinstein and others (2010). The volume of recharge generated by the SWB algorithm over the KMS domain is lower than the volume applied in the regional LMB model over the same domain. The average inland rate for the LMB model over the KMS model domain is $4.56 \mathrm{inch} / \mathrm{year}$ (in/yr), whereas the SWB application at the refined scale yields $4.25 \mathrm{in} / \mathrm{yr}$. This difference in average rate was removed by adjusting the SWB rates such that the KMS model yields the same overall volumetric input as the LMB model for the LMB domain. This adjustment was made while preserving the spatial distribution of relative rates at the $250-\mathrm{ft}$ grid spacing produced by the SWB algorithm. The SWB recharge values were scaled by a set of multipliers applied separately to the zones $1-5$ in figure 4-15 (the significance of these zones is explained in the following section). No multiplier is needed in zone 1 (over Lake Michigan) because the recharge rate is zero. The multipliers needed to make the SWB volumetric rates equal to the LMB model rates for zones 2, 3, 4, and 5 are 0.74233 , $1.168085,1.19878$, and 1.19878 , respectively. The scaled recharge rates are then subject to model calibration.

\section{Calibration of Kettle Moraine Springs (KMS) Model}

The history matching for the KMS model included an initial manual trial-and-error fit followed by an automated history matching using the software PEST (Doherty, 2014). The resulting optimal parameter values from each PEST run were evaluated for reasonableness. The final calibrated model was selected to have a good history matching to field measurements and reasonable parameter values.

History matching consisted of fitting simulated equivalent outputs to 434 field observations collected in the inset model domain. Field observations included 423 groundwater-head targets (fig. 4-16) (corresponding to glacial and Silurian well locations), and 11 groundwater discharge targets (fig. 4-17) (corresponding to 4 spring locations and 7 base-flow measurement locations). The discharge targets are presented in table 4-1. Weights used for history matching varied by target. All the wells were weighted around 1, except for three wells within the hatchery boundary that were given a weight of 10 . Discharge weights are smaller than head weights to normalize for unit differences. That is, discharge targets in units of cubic feet per day were orders of magnitude larger than head targets, which had units of feet. Spring targets were given a weight of 0.006. Stream base-flow target weights were scaled to account for differences in base-flow magnitude and ranged from $1.2214 \mathrm{e}^{-5}$ to $6.3524 \mathrm{e}^{-4}$. Collectively these weights give approximately equal importance to the grouped head targets and to the grouped discharge targets in terms of residuals (observed values minus simulated values) associated with the initial model parameterization. 


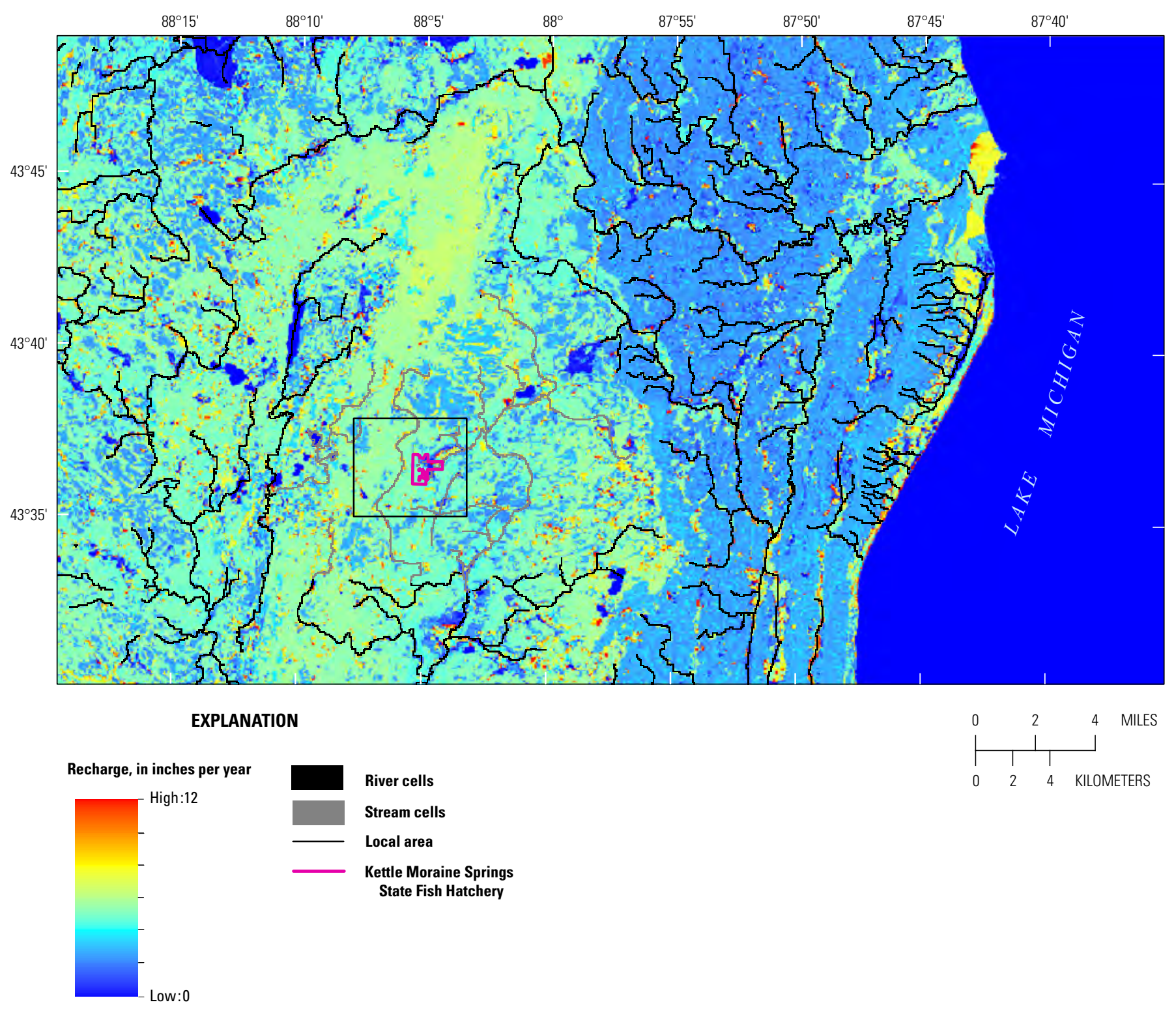

Figure 4-14. Distribution of recharge as generated by Soil-Water-Balance code (Westenbroek and others, 2010) in local area of the Kettle Moraine Springs model, Sheboygan County, Wisconsin. 


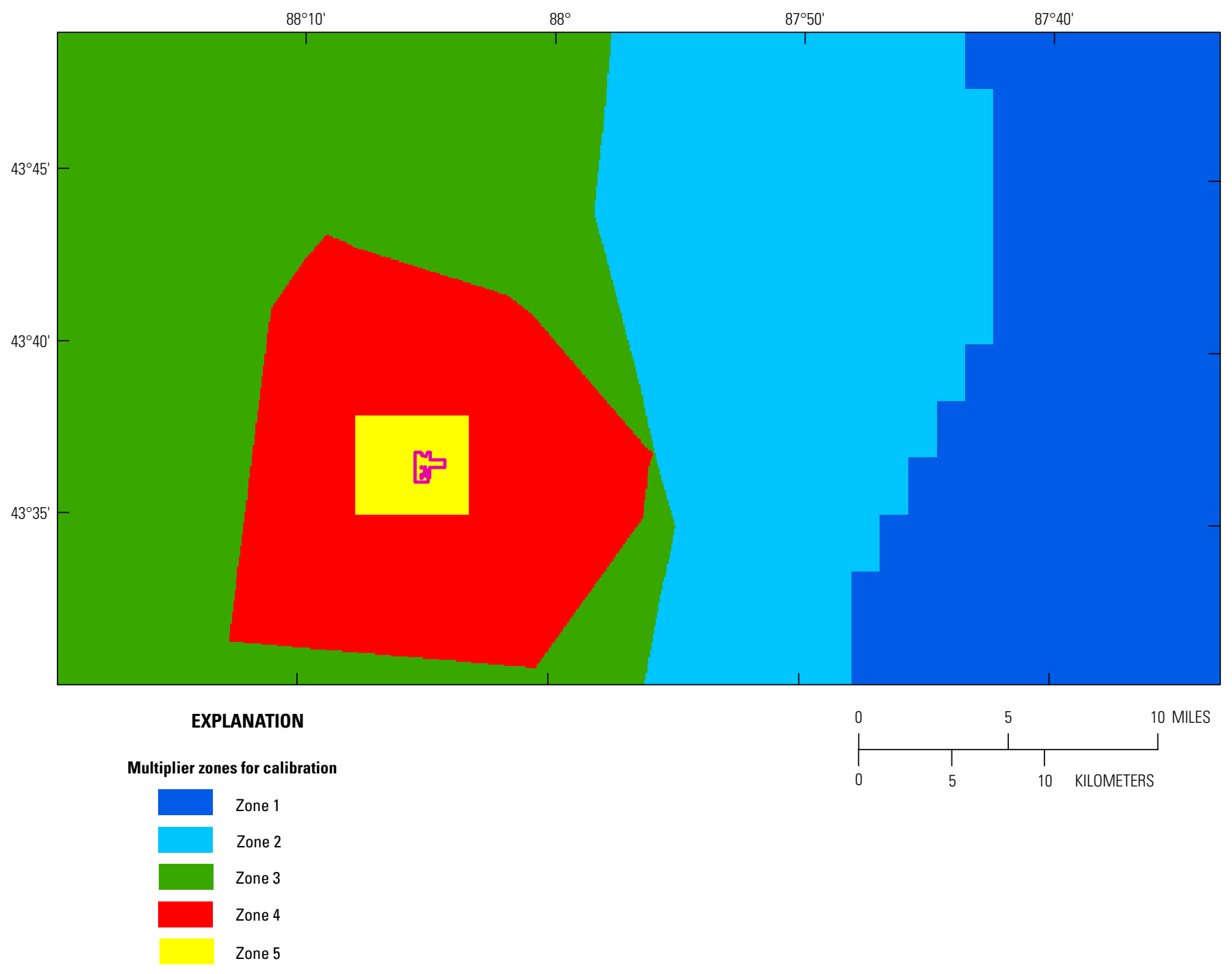

Kettle Moraine Springs State Fish Hatchery

Figure 4-15. Multiplier zones of the Kettle Moraine Springs (KMS) model, Sheboygan County, Wisconsin. 


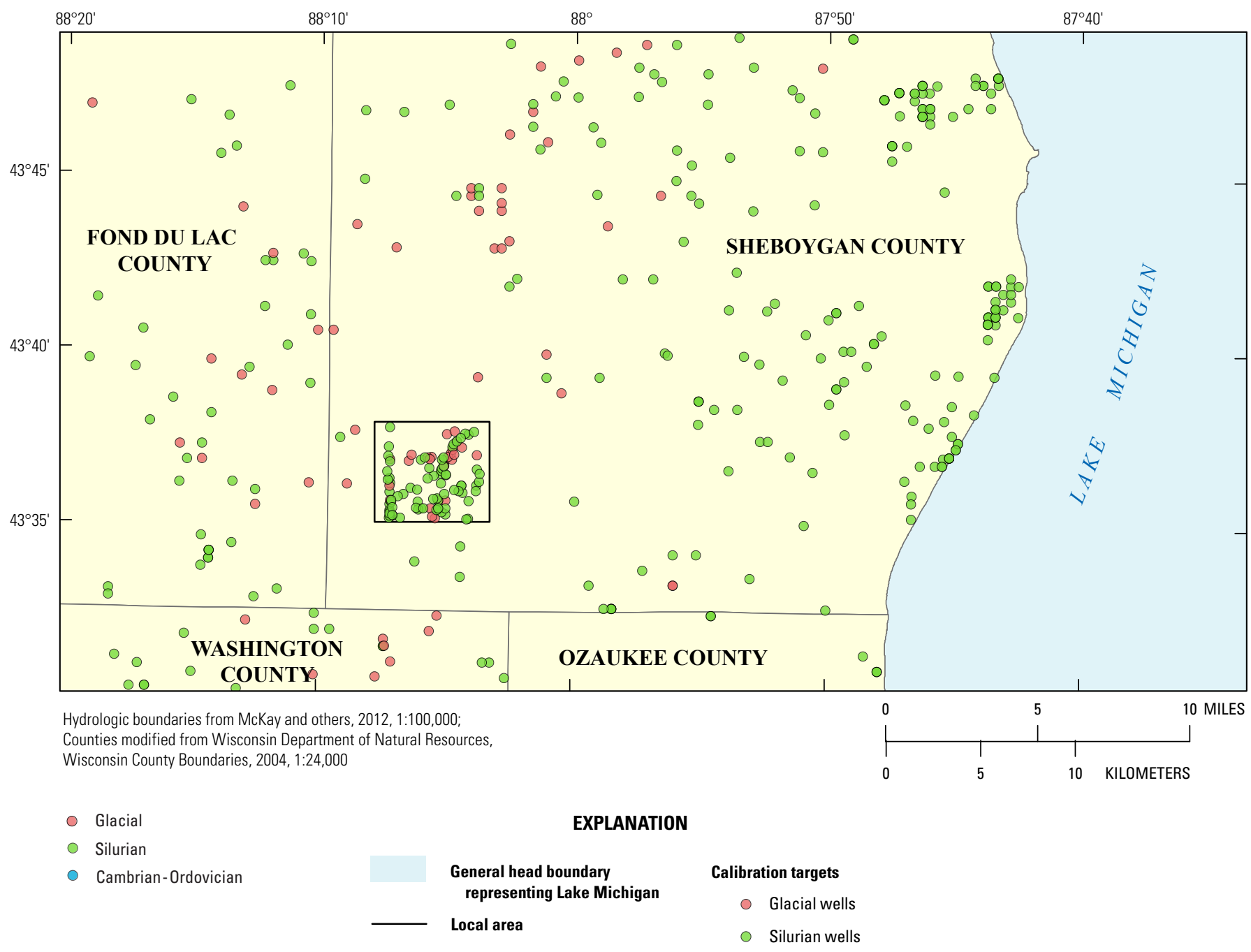

Figure 4-16. Groundwater-head targets used in PEST calibration of the Kettle Moraine Springs (KMS) model, Sheboygan County, Wisconsin. 


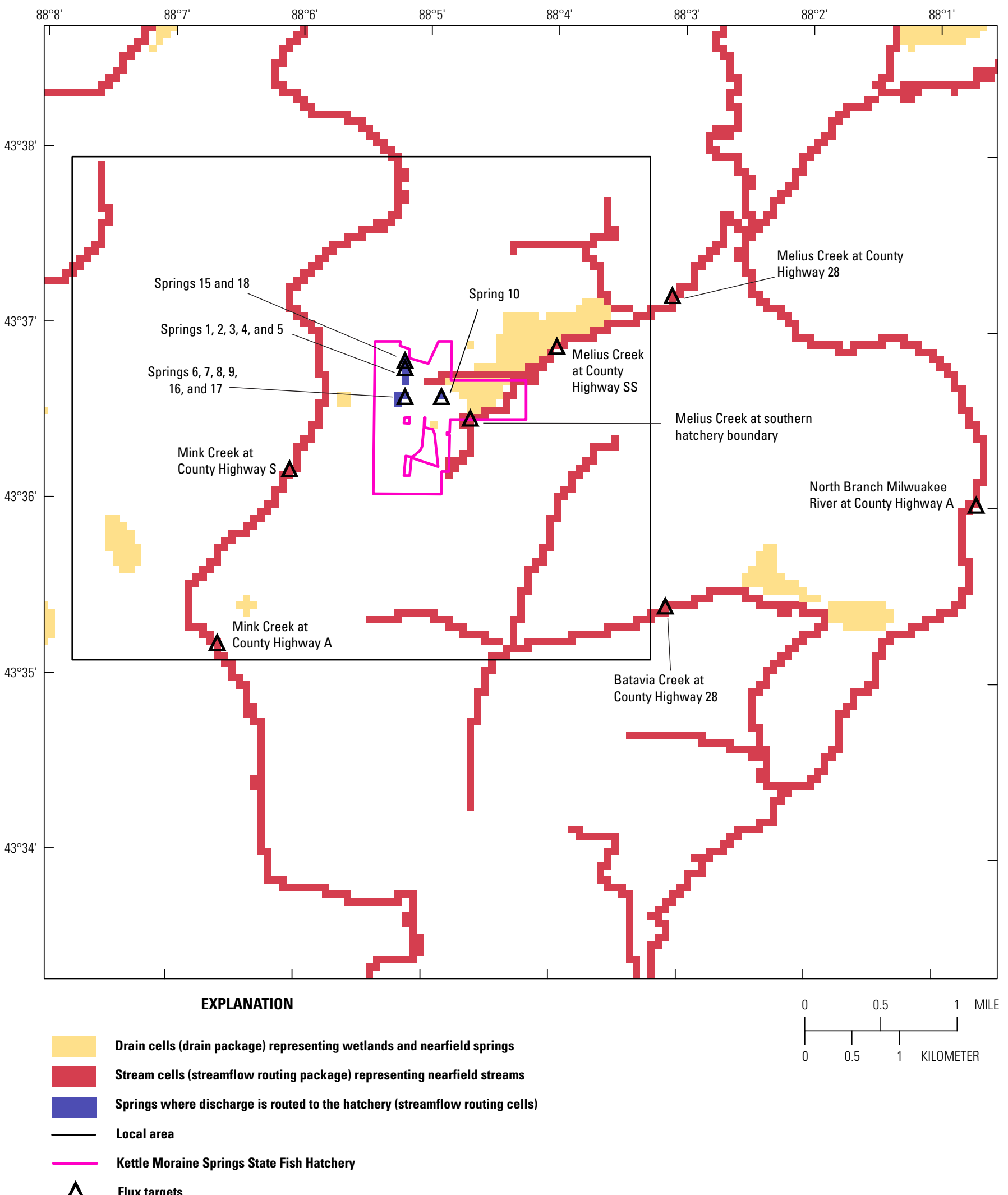

Figure 4-17. Flux targets used in PEST calibration of the Kettle Moraine Springs (KMS) model, Sheboygan County, Wisconsin. The flux targets represented base flow in 4 spring and 7 stream locations. 
Table 4-1. Measured discharge for surface-water sites near the Kettle Moraine Springs State Fish Hatchery, Sheboygan County, Wisconsin, February 2014.

[NA, not available or not measured]

\begin{tabular}{|c|c|c|}
\hline Location of discharge & $\begin{array}{l}\text { Measured discharge }{ }^{1} \\
\text { (cubic feet per second) }\end{array}$ & $\begin{array}{c}\text { Reported discharge }^{2} \\
\text { (cubic feet per second) }\end{array}$ \\
\hline Melius Creek at southern hatchery boundary & 0.36 & NA \\
\hline Batavia Creek at County Highway 28 & 0.94 & NA \\
\hline Melius Creek at County Highway SS & 2.27 & NA \\
\hline Mink Creek at County Highway S & 2.50 & NA \\
\hline Mink Creek at County Highway A & 3.96 & NA \\
\hline Melius Creek at County Highway 28 & 4.24 & NA \\
\hline North Branch Milwaukee at County Highway A & 18.95 & NA \\
\hline Spring 10 & NA & 0.09 \\
\hline Springs $6,7,8,9,16$, and 17 & NA & 0.62 \\
\hline Springs $1,2,3,4$, and 5 & NA & 0.62 \\
\hline Springs 15 and 18 & NA & 0.72 \\
\hline
\end{tabular}

\section{Multiplier Zones}

The history matching process for the KMS model consisted of optimizing multipliers on initial model input values. The multipliers are applied in a piecewise manner, meaning that initial model input values in a given model zone are varied with the same multiplier. The KMS model has been divided into five zones (fig. 4-15) intended to represent

Zone 1. Lake Michigan in the model farfield (203 square miles $\left[\mathrm{mi}^{2}\right]$ );

Zone 2. The farfield area covered by fine-grained tills derived from the Lake Michigan glacial lobe $\left(225 \mathrm{mi}^{2}\right)$;

Zone 3. The farfield area covered by largely coarsegrained deposits derived from the Green Bay glacial lobe $\left(260 \mathrm{mi}^{2}\right)$;

Zone 4. The nearfield area in the vicinity of (but not including) hatchery property $\left(134 \mathrm{mi}^{2}\right)$; and

Zone 5. The local area containing the hatchery property $\left(12.6 \mathrm{mi}^{2}\right)$.

The multipliers for each zone were either fixed at a value of 1.0 or allowed to vary as part of the calibration process. Multipliers were estimated for

- Horizontal hydraulic conductivity of the glacial deposits in layer 1 in zones 4 and 5;

- Vertical hydraulic conductivity of the glacial deposits in layer 1 in zones 4 and 5;
- Horizontal hydraulic conductivity of the glacial deposits in layers 2 and 3 in zones 4 and 5;

- Vertical hydraulic conductivity of the glacial deposits in layers 2 and 3 in zones 4 and 5;

- Horizontal hydraulic conductivity of the weathered Silurian in layer 4 in zones 4 and 5;

- Vertical hydraulic conductivity of the weathered Silurian in layer 4 in zones 4 and 5;

- Horizontal hydraulic conductivity of the deeper Silurian in layers 5 and 6 in zones 4 and 5;

- Vertical hydraulic conductivity of the deeper Silurian in layers 5 and 6 in zones 4 and 5;

- Recharge in zone 2;

- Recharge in zone 3;

- Recharge in zone 4; and

- Recharge in zone 5.

Each single multiplier was applied to initial model inputs that either vary cell by cell (hydraulic conductivity of the glacial deposits, recharge rates) or are uniform over large areas within a layer (hydraulic conductivity of the Silurian aquifer). The calibrated zonal multiplier values for hydraulic conductivity and recharge are presented in table $4-2$. 
Table 4-2. Calibrated zonal multiplier values for hydraulic conductivity and recharge for the Kettle Moraine Springs (KMS) model, Sheboygan County, Wisconsin.

[ $\mathrm{K}_{\mathrm{h}}$, horizontal hydraulic conductivity; $\mathrm{K}_{\mathrm{v}}$, vertical hydraulic conductivity]

\begin{tabular}{|c|c|c|c|}
\hline Parameter & Layer(s) & Zone & $\begin{array}{l}\text { Calibrated } \\
\text { multiplier }\end{array}$ \\
\hline $\mathrm{K}_{\mathrm{h}}$ & 1 & 4 & 2.403070 \\
\hline $\mathrm{K}_{\mathrm{v}}$ & 1 & 4 & 1.397270 \\
\hline $\mathrm{K}_{\mathrm{h}}$ & 2 and 3 & 4 & 0.809587 \\
\hline $\mathrm{K}_{\mathrm{v}}$ & 2 and 3 & 4 & 10.0 \\
\hline $\mathrm{K}_{\mathrm{h}}$ & 4 & 4 & 4.822780 \\
\hline $\mathrm{K}_{\mathrm{v}}$ & 4 & 4 & 2.365090 \\
\hline $\mathrm{K}_{\mathrm{h}}$ & 5 and 6 & 4 & 4.261510 \\
\hline $\mathrm{K}_{\mathrm{v}}$ & 5 and 6 & 4 & 3.050940 \\
\hline Recharge & not applicable & 2 & 0.890796 \\
\hline Recharge & not applicable & 4 & 1.582000 \\
\hline
\end{tabular}

${ }^{1} 0.1$ is the minimum allowable multiplier for $\mathrm{K}_{\mathrm{h}}$ (lowerbound in PEST); 10.0 is the maximum allowable multiplier for $\mathrm{K}_{\mathrm{v}}$ (upperbound in PEST); 1.582 is the maximum allowable multiplier for recharge (upperbound in PEST).

\section{Final Parameter Values}

For most of the inset KMS model domain, the vertical hydraulic conductivity assigned to the streambeds of the SFR streams was fixed at $5 \mathrm{ft} / \mathrm{d}$ and the thickness was set to $1 \mathrm{ft}$. For SFR cells representing the hatchery springs, the vertical hydraulic conductivity underneath the springs was allowed to vary to match measured spring flow. In addition, the vertical hydraulic conductivity in SFR reaches representing the stream within the hatchery was allowed to vary to facilitate better simulation of the distribution of flow to the springs and to the downstream reaches (fig. 4-11).

The final sets of inputs to the KMS model have calibrated values for

- The horizontal and vertical hydraulic conductivity of the glacial aquifer units, which vary on a cell-by-cell basis after calibration (as they did before) in the model nearfield and in the local area around the hatchery in layers 1 and 2 (layer 3 is pinched);

- The horizontal and vertical hydraulic conductivity of the Silurian aquifer units, which are uniform for weathered layer 4 and underlying layers 5 and 6 in the model nearfield and for the local area around the hatchery;

- The recharge rates, which vary on a cell-by-cell basis across the inland part of the model; and

- The hydraulic conductivity values assigned to the bed material of the springs.

The resulting final hydraulic conductivity values for the local area around the hatchery are presented in table 4-3. The cell-by-cell variation in the resulting final horizontal hydraulic conductivity for the local area of the KMS model is presented in figures 4-18 and 4-19. A simulation conducted using the final conductivity and recharge values resulted in a fit to the field measurements for these parameters that was generally good (figs. 4-20 and 4-21). The horizontal hydraulic conductivity distribution following calibration along the east/west

Table 4-3. Resulting final hydraulic conductivity values of the local area of the Kettle Moraine Springs (KMS) model, Sheboygan County, Wisconsin.

[Exponential notation is used to express some values for hydraulic conductivity]

\begin{tabular}{llccc}
\hline \multicolumn{1}{c}{ Stratigraphic unit and model layer } & \multicolumn{1}{c}{ Parameter } & $\begin{array}{c}\text { Average value } \\
\text { (feet per day) }\end{array}$ & $\begin{array}{c}\text { Minimum value } \\
\text { (feet per day) }\end{array}$ & $\begin{array}{c}\text { Maximum value } \\
\text { (feet per day) }\end{array}$ \\
\hline Glacial-layer 1 & Horizontal K & 9.8 & 0.1 & 34.3 \\
Glacial-layer 1 & Vertical K & 8.4 & 0.1 & 29.4 \\
Glacial-layer 2 & Horizontal K & 159.7 & 3.1 & $1,016.8$ \\
\hline Glacial-layer 2 & Vertical K & 7.0 & 0.1 & 7.4 \\
\hline Silurian-weathered layer 4 & Horizontal K & 7.4 & $4.1 \mathrm{E}-02$ & 7.4 \\
\hline Silurian-weathered layer 4 & Vertical K & $4.1 \mathrm{E}-02$ & 0.3 & $4.1 \mathrm{E}-02$ \\
\hline Silurian-layers 5 and 8 & Horizontal K & 0.3 & $2.0 \mathrm{E}-03$ & 0.3 \\
\hline Silurian-layers 5 and 8 & Vertical K & $2.0 \mathrm{E}-03$ & & $2.0 \mathrm{E}-03$ \\
\hline
\end{tabular}




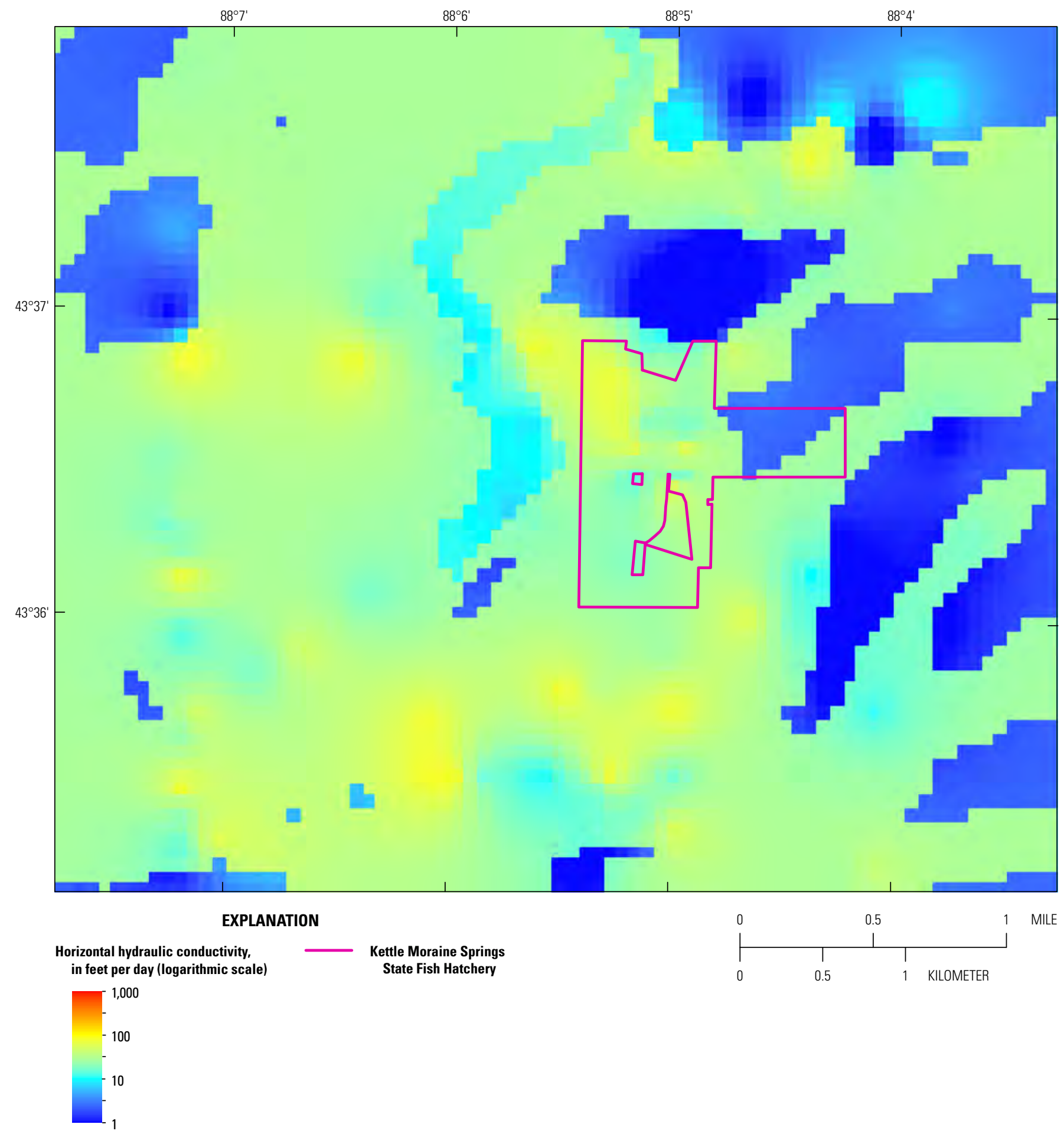

Figure 4-18. The resulting final horizontal hydraulic conductivity values for the layer $1 \mathrm{glacial}$ deposits in the local area of the Kettle Moraine Springs (KMS) model, Sheboygan County, Wisconsin. 


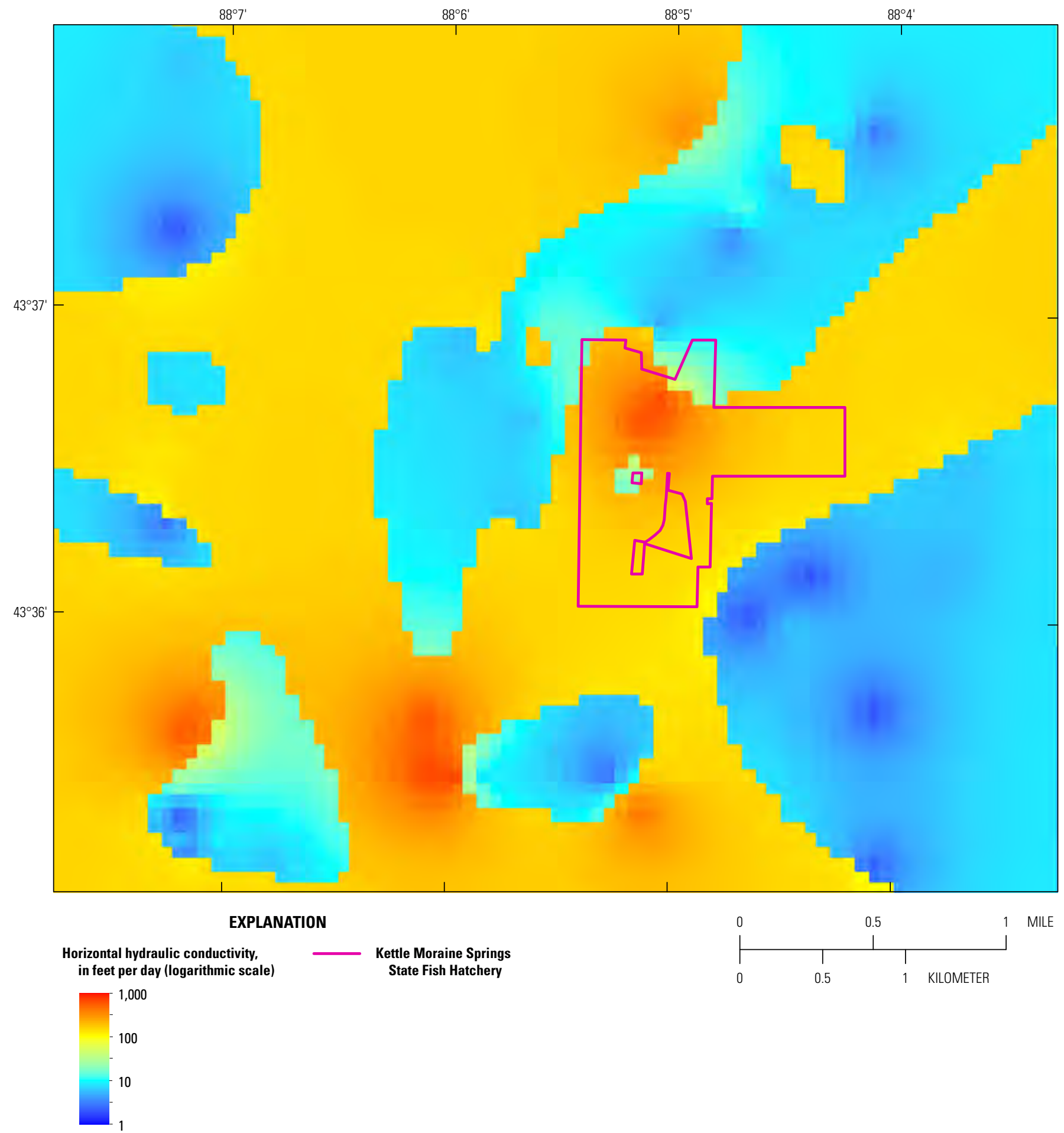

Figure 4-19. The resulting final horizontal hydraulic conductivity values for the layer 2 glacial deposits in the local area of the Kettle Moraine Springs (KMS) model, Sheboygan County, Wisconsin. 


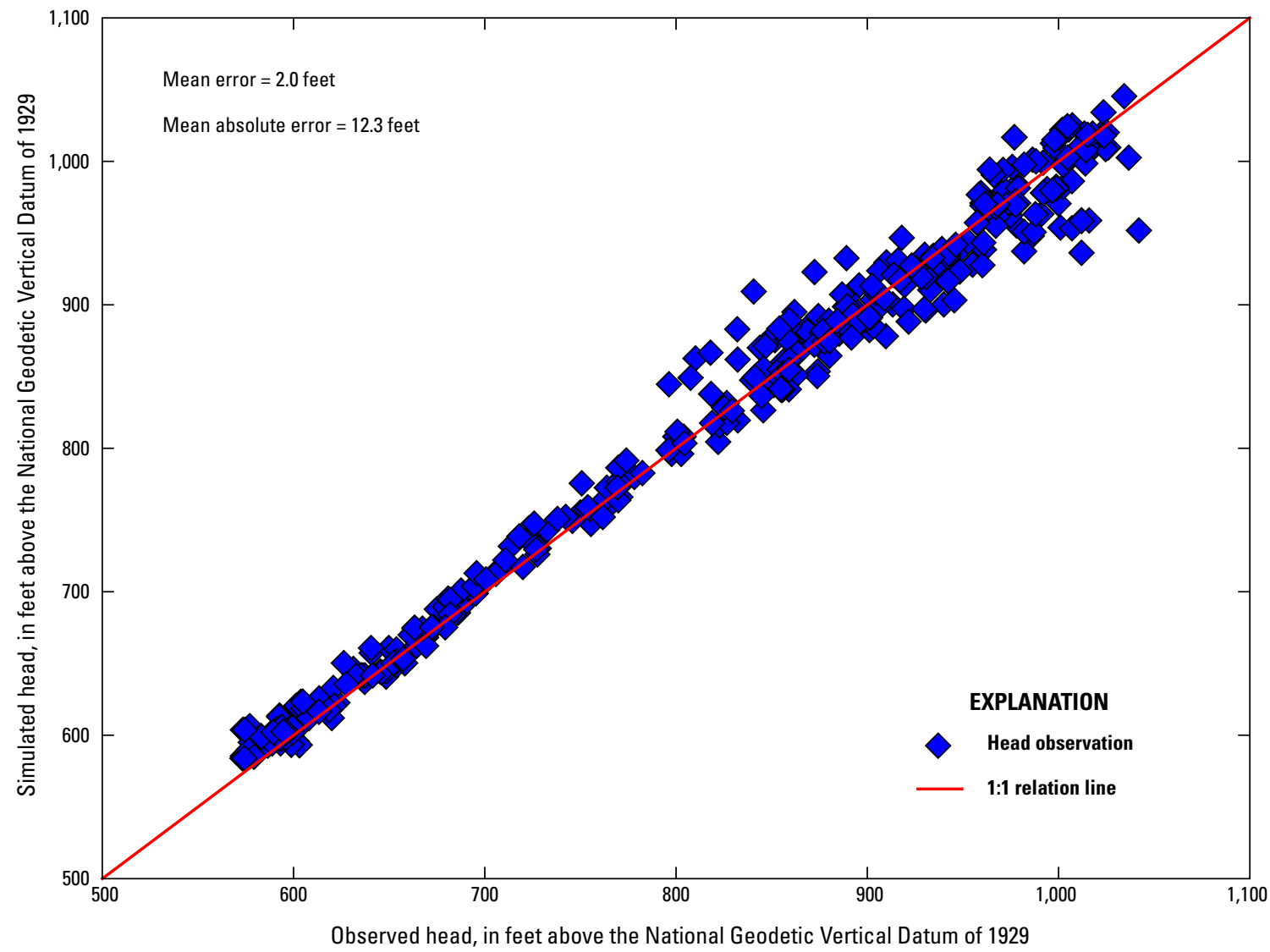

Figure 4-20. Match of simulated water levels to observed head targets following PEST calibration of the Kettle Moraine Springs (KMS) model, Sheboygan County, Wisconsin. 


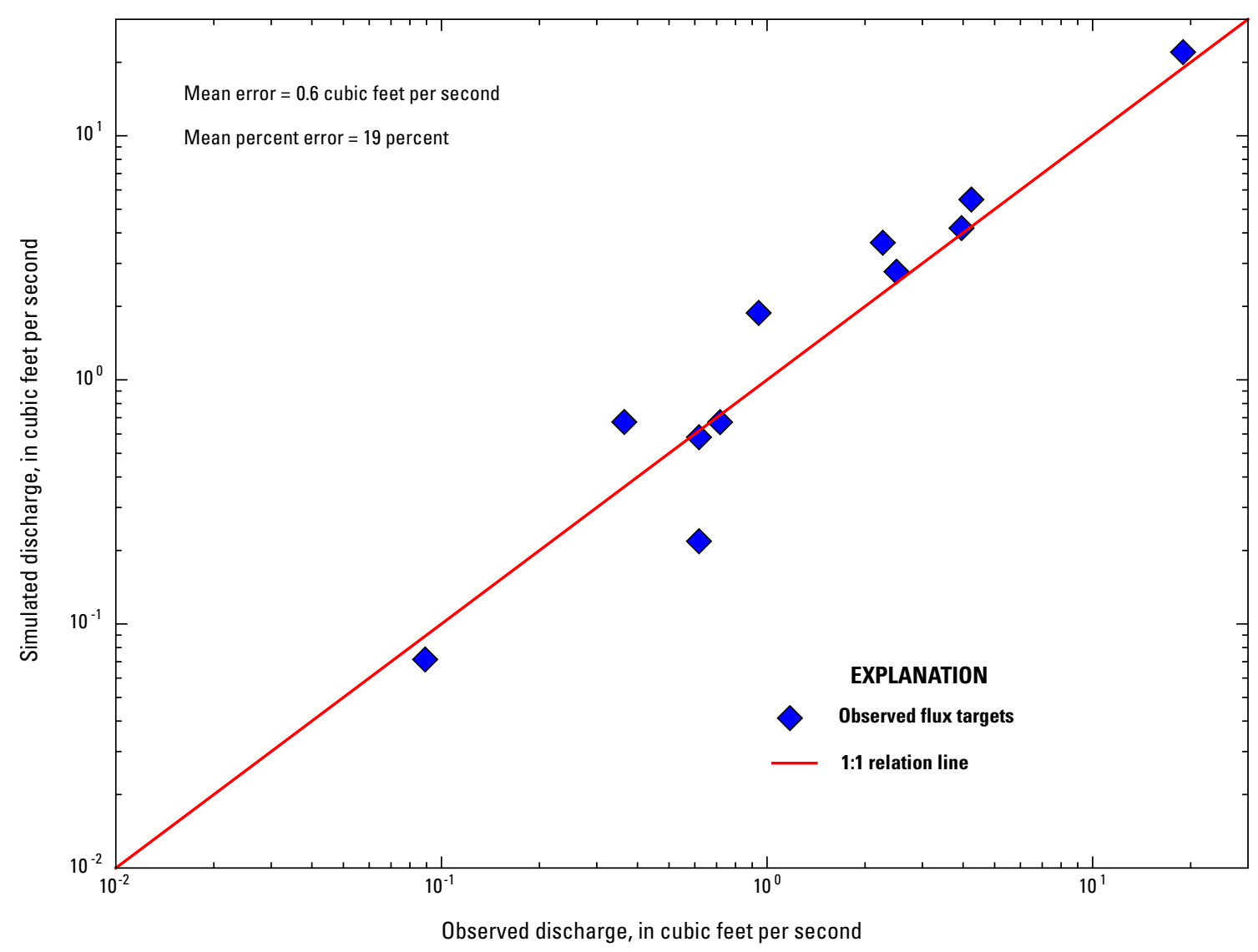

Figure 4-21. Match of simulated stream base flow and spring flux to observed flux targets following PEST calibration of the Kettle Moraine Springs (KMS) model, Sheboygan County, Wisconsin. 
cross section of the KMS model is provided in figure 4-22. The resulting transmissivity within the local area for the Silurian aquifer averages around $450 \mathrm{ft}^{2} / \mathrm{d}$, a value only one-third of that indicated by the aquifer pumping test conducted on the hatchery property (Conlon, 1995). This disagreement points to the possibility that there is not a single representative local value for the Silurian aquifer given the heterogeneity attributable to fracture zones. The relatively low Silurian transmissivity for the local area around the hatchery in the calibrated KMS model is conservative from the standpoint of evaluating how much water can be extracted from Silurian wells for hatchery operations.

The resulting final recharge zone multipliers yield the following average recharge rates for the model calibration zones:
Zone 2
$2.9 \mathrm{in} / \mathrm{yr}$
Zone 3
$6.6 \mathrm{in} / \mathrm{yr}$
Zone 4 and Zone 5 together
$7.8 \mathrm{in} / \mathrm{yr}$
Zone 5 only
$7.9 \mathrm{in} / \mathrm{yr}$

It is notable that zone 2, associated with fine-grained till, receives on average less than half the recharge received by zones associated with the more coarse-grained Kettle Moraine area of zone 3. Distribution of recharge, in which the values presented in figure 4-14 have been adjusted by applying recharge zone multiplication factors to result in the rates listed above, is provided in figure 4-23.

The calibrated vertical hydraulic conductivity values assigned to the bed material of the springs are sensitive to the discharge targets measured at the springs. The values vary by location from about $0.01 \mathrm{ft} / \mathrm{d}$ to about $2 \mathrm{ft} / \mathrm{d}$, with the highest values estimated for the springs located farthest to the northwest (fig. 4-11). However, many small-scale hydrogeological characteristics remain simplified in the inset KMS model (for example, preferential flow-path geometry and distribution; three-dimensional head distribution in the aquifer adjacent to the spring). Therefore, the optimal vertical hydraulic conductivity values for the springs should be considered to be "surrogate" inputs - that is, vehicles to simulate observed spring flows in the inset KMS model and not necessarily representative of site characteristics if small-scale measurements were to be made in the field.

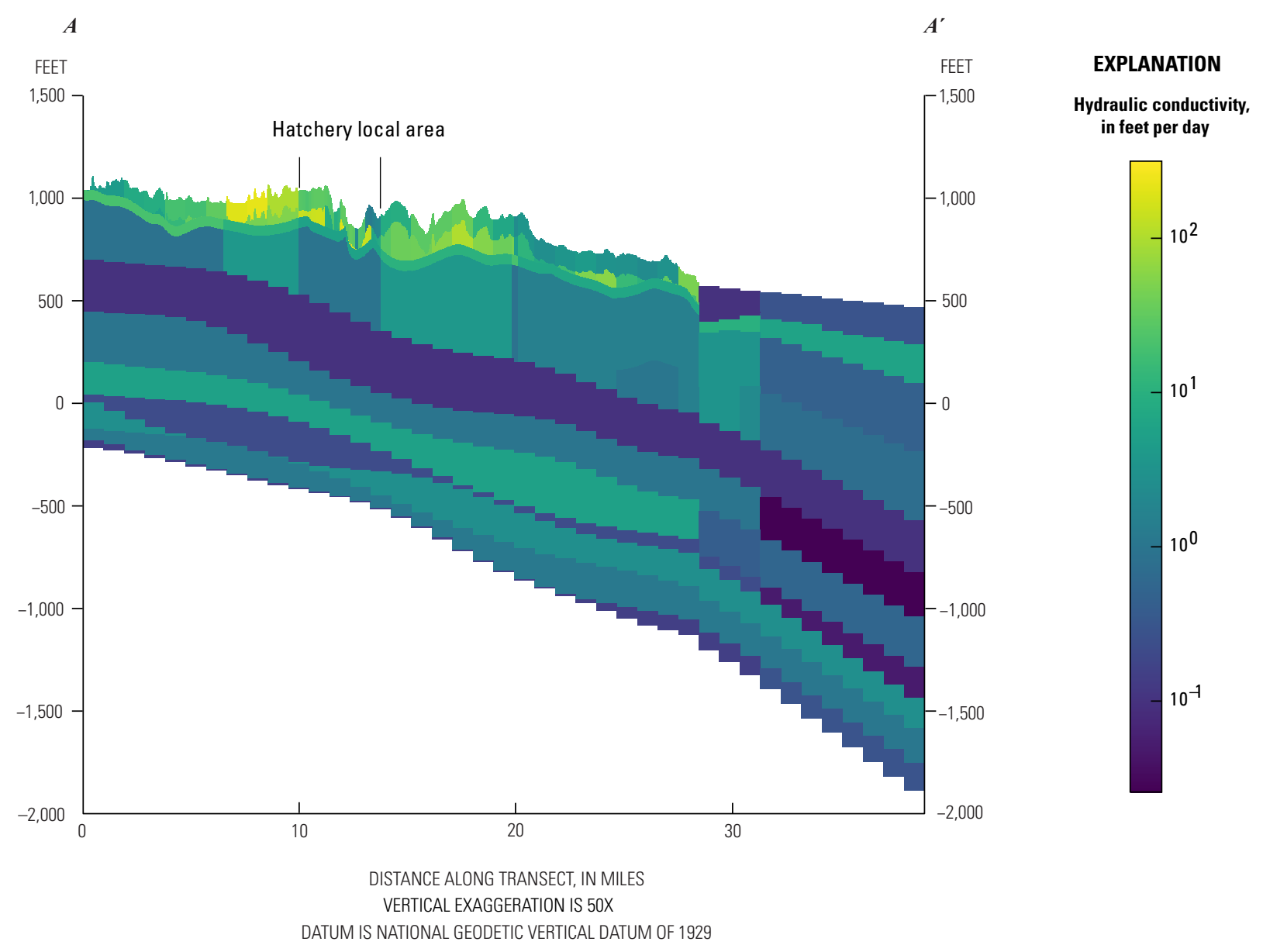

Figure 4-22. Horizontal hydraulic conductivity distribution following calibration along east/west cross section of the Kettle Moraine Springs (KMS) model through hatchery property, Sheboygan County, Wisconsin. 


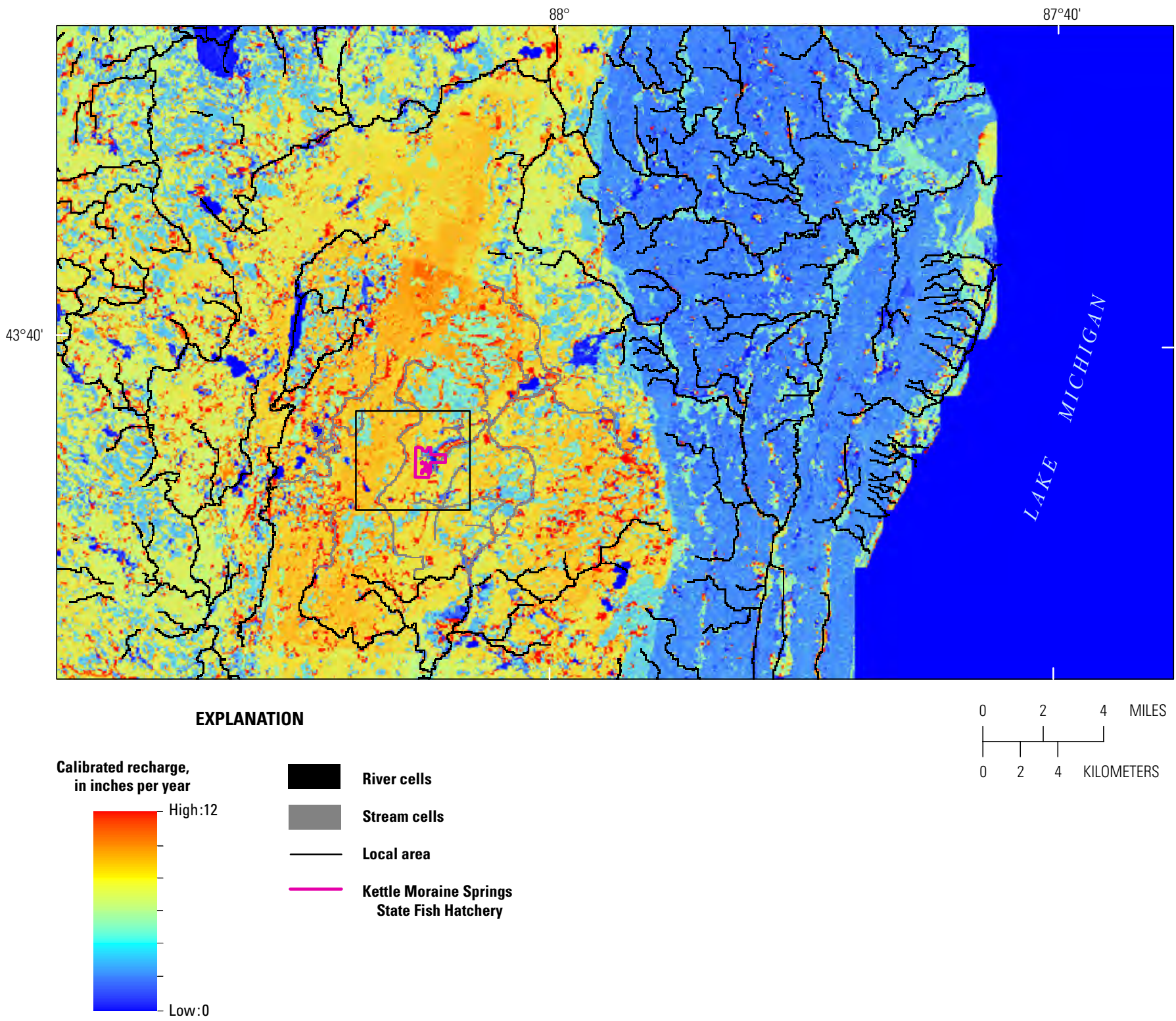

Figure 4-23. Distribution of recharge in which the values, generated by the Soil-Water-Balance code (Westenbroek and others, 2010) presented in figure 4-14, have been adjusted by applying multiplication factors following calibration of the Kettle Moraine Springs (KMS) model, Sheboygan County, Wisconsin. 


\section{References}

Barnes, H.H., 1967, Roughness characteristics of natural channels: U.S. Geological Survey Water Supply Paper 1849,213 p.

Buchwald, C.A., Luukkonen, C.L., and Rachol, C.M., 2010, Estimation of groundwater use for a groundwaterflow model of the Lake Michigan Basin and adjacent areas, 1864-2005: U.S. Geological Survey Scientific Investigations Report 2010-5068, 120 p.

Carlson, A.E., Principato, S.M., Chapel D.M., and Mickelson D.M., 2011, Quaternary geology of Sheboygan County, Wisconsin: Wisconsin Geological and Natural History Survey, Bulletin 106, 32 p., 2 pls.

Conlon, T.D., 1995, Hydrogeology of southwestern Sheboygan County, Wisconsin, in the vicinity of the Kettle Moraine Springs Fish Hatchery: U.S. Geological Survey Water-Resources Investigations Report 94-4106, 17 p.

Doherty, John, 2014, PEST, Model-independent parameter estimation-User manual (5th ed., with slight additions): Brisbane, Australia, Watermark Numerical Computing.

Dunning, C.P., Feinstein, D.T., Hunt, R.J., and Krohelski, J.T., 2004, Simulation of ground-water flow, surface-water flow, and a deep sewer tunnel system in the Menomonee Valley, Milwaukee, Wisconsin: U.S. Geological Survey Scientific Investigations Report 2004-5031, 40 p.

Feinstein, D.T., Hunt, R.J., and Reeves, H.W., 2010, Regional groundwater-flow model of the Lake Michigan Basin in support of Great Lakes Basin water availability and use studies: U.S. Geological Survey Scientific Investigations Report 2010-5109, 379 p.

Fry, J.A., Xian, G., Jin, S., Dewitz, J.A., Homer, C.G., Limin, Y., Barnes, C.A., Herold, N.D., and Wickham, J.D., 2011, Completion of the 2006 national land cover database for the conterminous United States: Photogrammetric engineering and remote sensing, v. 77, no. 9, p. 858-864.

Gesch, D., Oimoen, M., Greenlee, S., Nelson, C., Steuck, M., and Tyler, D., 2002, The national elevation dataset: Photogrammetric Engineering and Remote Sensing, v. 68 , p. $5-12$.

Juckem, P.F., Clark, B.R., and Feinstein, D.T., 2017, Simulation of groundwater flow in the glacial aquifer system of northeastern Wisconsin with variable model complexity: U.S. Geological Survey Scientific Investigations Report 2017-5010, 52 p.
Mueller, S.D., 1992, Three-dimensional digital simulation of the ground-water contribution to Lake Michigan from the Silurian aquifer of southeastern Wisconsin: University of Wisconsin-Milwaukee, unpublished M.S. thesis, 231 p.

Syverson K.M., Clayton L., Attig, J.W., and Mickelson, D.M., 2011, Lexicon of Pleistocene stratigraphic units of Wisconsin: Wisconsin Geological and Natural History Survey Technical Report 1, 180 p.

Thornton, P.E., Thornton, M.M., Mayer, B.W., Wilhelmi, N., Wei, Y., Devarakonda R., and Cook, R.B., 2014, DaymetDaily surface weather data on a 1-km grid for North America, version 2: ORNL DAAC, accessed July 10, 2013, at http://dx.doi.org/10.3334/ORNLDAAC/1219.

U.S. Department of Agriculture, 2009, Soil Survey Geographic (SSURGO) database for Wisconsin, accessed February 19, 2009, at https://sdmdataaccess.nrcs.usda.gov/.

U.S. Geological Survey, 2016a, National Elevation Dataset, accessed March 15, 2016, at http://ned.usgs.gov/.

U.S. Geological Survey, 2016b, Hydrography-National hydrography dataset, accessed March 15, 2016, at https://nhd.usgs.gov/index.html.

Webb, E.K., 1989, Estimating groundwater discharge to Lake Michigan using a three-dimensional groundwater flow model, along a portion of the shoreline from Door County to Port Washington, Wisconsin: University of WisconsinMadison, unpublished M.S. thesis, 227 p.

Westenbroek, S.M., Kelson, V.A., Dripps, W.R., Hunt, R.J., and Bradbury, K.R., 2010, SWB-A modified Thornthwaite-Mather Soil-Water-Balance code for estimating groundwater recharge: U.S. Geological Survey Techniques and Methods book 6, chap. A31, 60 p.

Wisconsin Department of Natural Resources, 2016, The groundwater retrieval network, accessed October 2016 at http://dnr.wi.gov/topic/Groundwater/grn.html.

Wisconsin Geological and Natural History Survey, 2011, Bedrock stratigraphic units in Wisconsin: Wisconsin Geological and Natural. History Survey Educational Series 51, 4 p. 


\section{Appendix 5. Application of the Pumping Test (PT) Model and the Lake Michigan Basin (LMB) Modified Model to Cambrian-Ordovician Aquifer System Water Supply Scenarios}

\section{Figures}

5-1. Map showing simulated drawdown at top of the Cambrian-Ordovician aquifer system (model layer 3) resulting from a 72-hour aquifer pumping test using the Pumping Test model, Sheboygan County, Wisconsin ..

5-2. Map showing area of the regional Lake Michigan Basin (LMB) model within which the horizontal hydraulic conductivity and specific storage values have been modified for the Maquoketa confining unit and the Cambrian-Ordovician aquifer units, based on results from simulation of the aquifer pumping test using the Pumping Test (PT) model, Sheboygan County, Wisconsin

\section{Tables}

5-1. Determination of allowable drawdown inside the test production well borehole during the aquifer pumping test of the Cambrian-Ordovician aquifer system at the Kettle Moraine Springs State Fish Hatchery, Sheboygan County, Wisconsin

5-2. Updated values of horizontal hydraulic conductivity and transmissivity in Pumping Test model and in local areas of the Lake Michigan Basin model

5-3. Updated values of specific storage and storativity for combined Cambrian-Ordovician units in the Pumping Test model and local area of the Lake Michigan Basin modified model. 
The calibrated Pumping Test model (PT model) serves to estimate water availability for the hatchery from the Cambrian-Ordovician aquifer system (COAS) in two ways:

1. The model is applied directly to simulate drawdown conditions in and around the candidate pumping wells where the grid spacing is fine and the multi-node well package allows the simulation of the water level within the boreholes of candidate deep supply wells; and

2. The transmissivity and storage values yielded by the calibration process using the aquifer pumping test data are inserted as local updates into the revised regional model - the Lake Michigan Basin (LMB) modified model. The LMB modified model was then applied to simulate regional drawdown conditions, including drawdown at the closest existing well completed in the COAS located about 9.6 miles (mi) west of the hatchery property.

The PT model, with its schematic layering and simple constant-head boundaries, cannot be applied directly to predict regional conditions because it does not support the conditions necessary to properly account for regional sources of water to the deep aquifer from overlying aquifers. Sensitivity runs with the PT model show that simulated drawdown conditions on the hatchery property and inside any pumping well boreholes is almost completely insensitive to the boundary conditions imposed on the model, but that the regional drawdown pattern (for example, at the Campbellsport well shown in fig. 17 of the main text) does depend on flow conditions governed in large measure by the thinning and subcropping of the Maquoketa Shale, miles to the west of the hatchery property. In contrast, the regional LMB model does include the boundary conditions, layering, and parameterization necessary to properly account for diffused and concentrated leakage from the shallow to the deep flow system, and thereby, to more reliably simulate the regional response to deep pumping and its effect on competing wells in the COAS. In the spirit of step-wise modeling (Anderson and others, 2015), the pumping test analysis performed with the PT model yields local improvements to the LMB model (within the area of influence of the pumping test), and hence combines the benefits of a regional model with a revised representation of local conditions. This same model, with the 5,000-foot (ft) grid spacing, is completely inadequate to simulate drawdown in and around candidate pumping wells, whereas for that purpose, the nonuniform grid of the PT model is well suited. The application of two models, in such a way to exploit their strengths and minimize their weaknesses, allows a more reliable estimate of the amount of water that can be extracted from the COAS for hatchery supply.

The key constraint on potential groundwater withdrawal that was evaluated using the PT model is the simulated drawdown within the boreholes for the two-well and three-well scenarios discussed in the main text. The finite-difference code MODFLOW Multi-Node Well (MNW2) package (Konikow and others, 2009) was used because it provides a realistic representation of the ability of a well to sustain the desired pumping without causing the water level inside the borehole to fall into the open interval of the well. The open intervals of the candidate wells, including the well drilled in 2015 and used in the pumping test, extend from the top of the Sinnipee Group (that is, from the top of the Cambrian-Ordovician bedrock aquifer system) to the bottom of the St. Peter Sandstone. To be more conservative in this assessment of the groundwater resource available, the constraint actually applied to the candidate wells is that simulated water level inside the borehole does not fall lower than $100 \mathrm{ft}$ above the top altitude of the Sinnipee (table 5-1). The top of the Sinnipee Group

Table 5-1. Determination of allowable drawdown inside the test production well borehole during the aquifer pumping test of the Cambrian-Ordovician aquifer system at the Kettle Moraine Springs State Fish Hatchery, Sheboygan County, Wisconsin. The Sinnipee unit is the uppermost stratigraphic unit of the Cambrian-Ordovician section at the hatchery.

[datum, North American Vertical Datum of 1988 (NAVD 88; --, not applicable or no data available)

\begin{tabular}{lcc}
\hline $\begin{array}{c}\text { At the test production well (PW1) } \\
\text { at the Kettle Moraine Springs } \\
\text { State Fish Hatchery }\end{array}$ & $\begin{array}{c}\text { Altitude } \\
\text { (feet above } \\
\text { datum) }\end{array}$ & $\begin{array}{c}\text { Drawdown } \\
\text { (feet) }\end{array}$ \\
\hline Land surface & 884 & -- \\
Top of Sinnipee unit & 214 & -- \\
Sinnipee unit altitude plus $100 \mathrm{ft}$ & 314 & -- \\
Static water altitude & 757 & -- \\
Allowable drawdown & & 443 \\
$\quad$ (757 feet minus 314 feet) & -- & \\
\hline
\end{tabular}

${ }^{1}$ Allowable drawdown is equated with difference between static water-level altitude. 
at the test production well location is $214 \mathrm{ft}$ above the North American Vertical Datum of 1988 (NAVD 88); therefore, the applied constraint altitude is $314 \mathrm{ft}$. The static water level of the well is $757 \mathrm{ft}$, allowing $443 \mathrm{ft}$ of drawdown without violating this constraint. The 100-ft safety factor is intended to ensure that the saturated thickness in contact with wells completed in the COAS is not compromised by water levels that fall into the aquifer system and acts to reduce the effective transmissivity. A time constraint was also applied to this problem-20 years of cyclical pumping with a low and high rate each year (see the section titled "Pumping Test (PT) Model - Estimated Water Supply from the Cambrian-Ordovician Aquifer System" in main text for details). The solution that was achieved effectively maximizes the available withdrawals for the seasonal high rate of pumping after 20 years of pumping subject to the borehole drawdown constraint.

The calibration of the PT model indicated that the permeability of the well skin at the existing pumping well (assumed to be present in a 1.2-inch annular space around the borehole) is high (around $8 \mathrm{feet} / \mathrm{day}[\mathrm{ft} / \mathrm{d}]$ ) relative to the formation hydraulic conductivity; therefore, only a very small amount of additional drawdown is induced relative to the head loss in the aquifer. It is possible that the skin of the existing well will lose permeability with time. It is also possible that other wells drilled onsite and completed in the COAS will be less efficient because they are more subject to a skin effect. These are additional reasons for applying a safety factor of $100 \mathrm{ft}$ to simulations of the available drawdown at the candidate pumping wells.

The update to the regional LMB model, which results in the LMB modified model, consists of a revision of the horizontal hydraulic conductivity and specific storage of the Cambrian-Ordovician units and overlying Maquoketa Shale within the area of influence of the pumping test. The area of influence is defined as the radial distance to the $0.01 \mathrm{ft}$ drawdown contour simulated by the calibrated PT model for the 3-day pumping test. This radial distance is about $5 \mathrm{mi}$ (fig. 5-1). The parameter values subject to change in the LMB model over the same area (fig. 5-2) are in layers 13-19, representing the Maquoketa Shale, Sinnipee aquifer/confining unit, St. Peter sandstone aquifer unit, Trempealeau-Tunnel City aquifer/confining unit, Ironton-Galesville aquifer unit, Eau Claire aquifer/ confining unit, and Mount Simon aquifer unit. The guiding principle for changing the horizontal hydraulic conductivity in these LMB model layers is to duplicate the same transmissivity of the COAS derived from the calibration of the PT model over the area of influence of the test.

The unit layering for the Maquoketa Shale and COAS in the PT model (layers 2-8) corresponds to the unit layering in the LMB modified model (layers 13-19). However, whereas the thickness of each unit in the PT model is uniform and flatlying, the unit thickness varies spatially in the LMB modified model; moreover, the thicknesses assigned to the units in the PT model are based on the geophysical log at the observation well (MW), and the thicknesses in the LMB modified model are derived from an interpolation of geologic and lithologic logs over a large area. The total Maquoketa Shale plus COAS thickness (note that the Mount Simon unit is assumed to be very thin or absent in the hatchery area) is $726 \mathrm{ft}$ in the PT model, but it is $874 \mathrm{ft}$ in the LMB modified model at the row/column location that includes the installed deep pumping well. Table 5-2 shows the thickness of each unit in the PT and LMB models. It also shows the initial horizontal hydraulic conductivity values assigned the PT model, which are identical to those in the original LMB model over a zone that includes the hatchery property. The transmissivity values for the PT and LMB models at the hatchery property are 1,690 and 1,239 square feet per day ( $\left.\mathrm{ft}^{2} / \mathrm{d}\right)$, respectively. (Note that the deep Cambrian-Ordovician units are fully saturated, so that transmissivity is equal to horizontal hydraulic conductivity multiplied by unit thickness). However, the calibration of the PT model yielded a multiplier of 0.432 on the assigned hydraulic conductivity values and a final transmissivity value equal to $729 \mathrm{ft}^{2} / \mathrm{d}$. Because of the difference in aquifer thicknesses in the two models, the local transmissivity of the LMB modified model in the COAS over the area of influence of the pumping test was adjusted with a multiplier of 0.589 to the individual unit hydraulic conductivity values as shown in table $5-2$. This adjustment results in transmissivity of the entire COAS in the LMB modified model to equal the calibrated transmissivity of the entire COAS from the PT model.

A similar logic was used to update local specific storage values in the LMB modified model (table 5-3). Calibration of the PT model to the pumping test yielded a specific storage factor of $2.96 \mathrm{e}^{-7} 1 / \mathrm{ft}$, summing to a storativity value of $2.16 \mathrm{e}^{-4}$ over the deep aquifer thickness. Given the thickness difference in the two models at the hatchery location, the specific storage appropriate to the LMB modified model is $2.46 \mathrm{e}^{-7} 1 / \mathrm{ft}$, implying a storativity equivalent to that of the PT model equal to $2.16 \mathrm{e}^{-4}$.

The LMB modified model is applied to the CambrianOrdovician pumping scenarios in a different way than the PT model. The distance between the scenario wells is on the same scale as a single row/column location of the LMB model; the maximum distance between candidate wells is $5,100 \mathrm{ft}$, the LMB modified model grid spacing is $5,000 \mathrm{ft}$; therefore, for the purposes of the prediction of regional deep drawdown, the pumping from the 2 or 3 candidate wells is combined into a single well that is open to the Sinnipee and St. Peter layers. Whereas the PT model was run in transient mode with multiple stress periods to simulate cyclical annual pumping over 20 years, the LMB modified model is run in transient mode for a single 20 -year stress period with constant pumping set equal to the average of the time-weighted cyclical rates in the PT model (800 and 900 gallons per minute [gal $/ \mathrm{min}$ ] for the 2 or 3 well scenarios, respectively). The initial conditions at the beginning of the 20 -year stress period with the cyclical pumping are determined by simulating the modified LMB model for a series of stress periods that represent historical pumping conditions from 1864 to 2000, as described in Feinstein and others, 2010. The drawdown simulated by the modified LMB model represents the change in head from the 2000 conditions. 


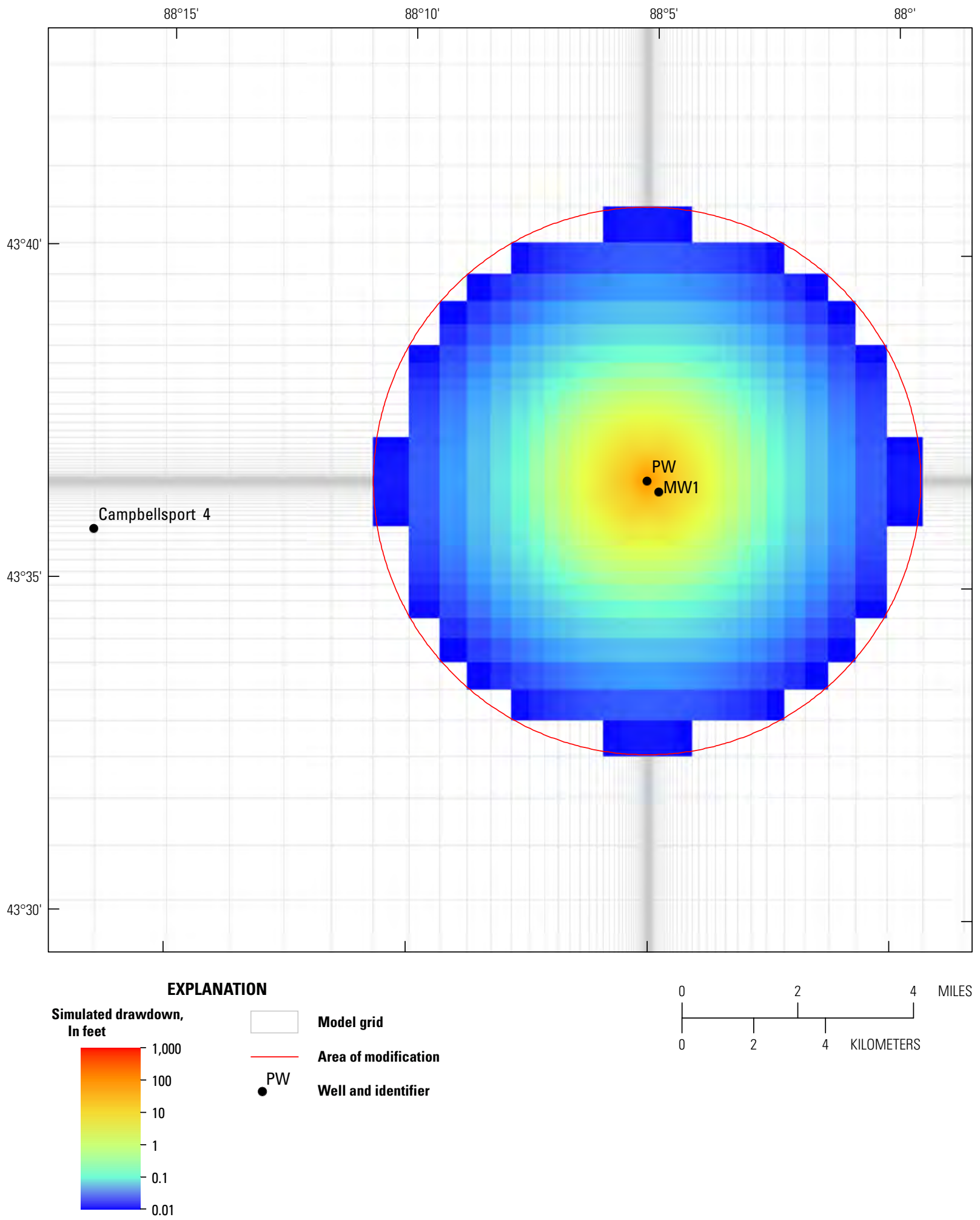

Figure 5-1. Simulated drawdown at top of the Cambrian-Ordovician aquifer system (model layer 3) resulting from a 72-hour aquifer pumping test using the Pumping Test model, Sheboygan County, Wisconsin. 


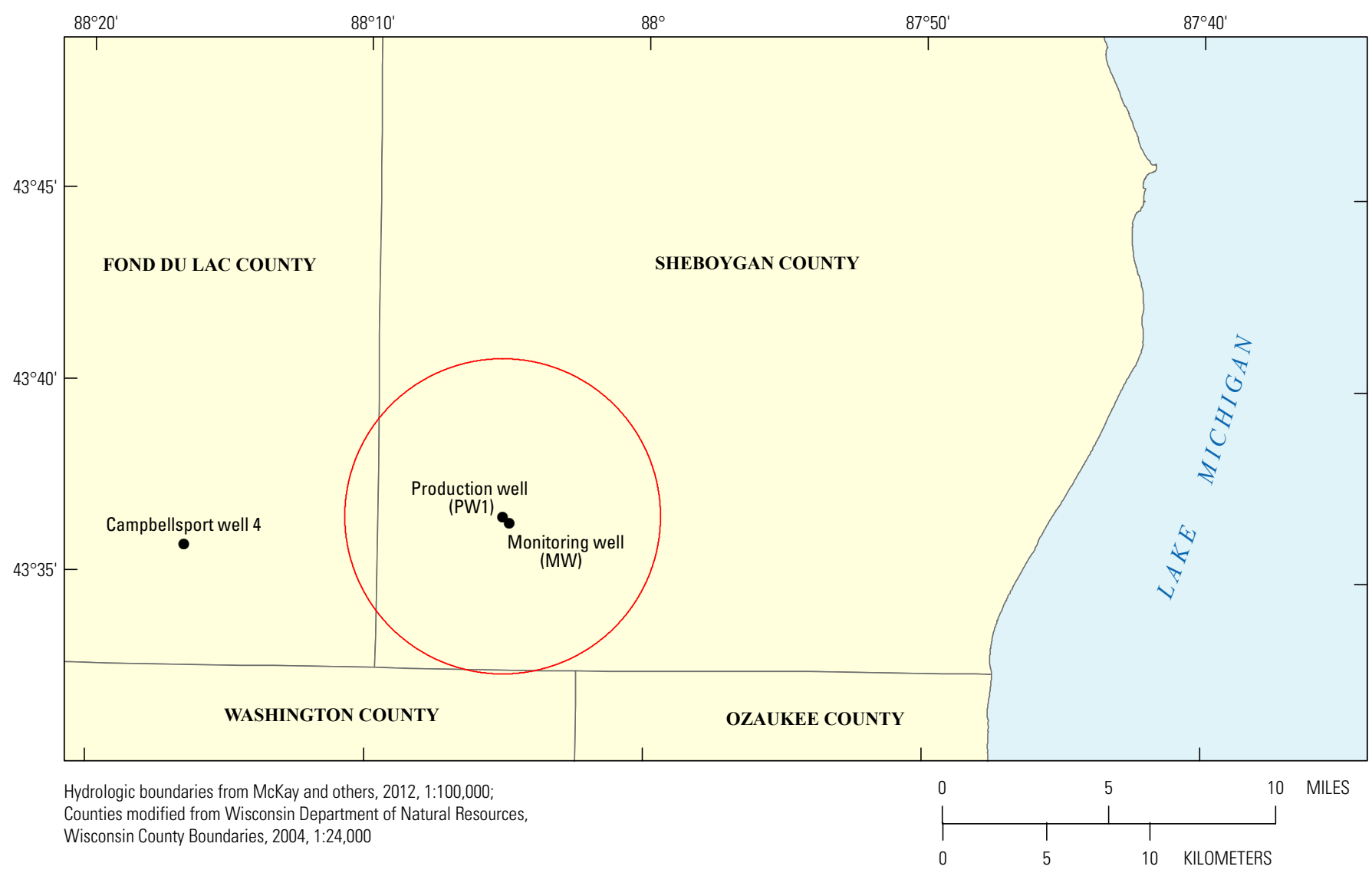

EXPLANATION

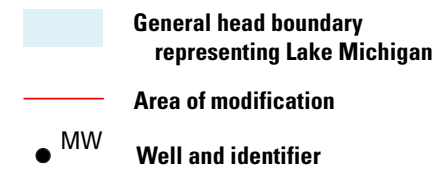

Figure 5-2. Area of the regional Lake Michigan Basin (LMB) model within which the horizontal hydraulic conductivity and specific storage values have been modified for the Maquoketa confining unit and the Cambrian-Ordovician aquifer units, based on results from simulation of the aquifer pumping test using the Pumping Test (PT) model, Sheboygan County, Wisconsin. 
Table 5-2. Updated values of horizontal hydraulic conductivity and transmissivity in Pumping Test model and in local areas of the Lake Michigan Basin model.

[ft, foot; $\mathrm{ft} / \mathrm{d}$, foot per day; $\mathrm{ft}^{2} / \mathrm{d}$, square foot per day; --, indicates not applicable or no data]

\begin{tabular}{|c|c|c|c|c|c|c|}
\hline \multirow[b]{2}{*}{ Stratigraphic unit } & \multicolumn{6}{|c|}{ Pumping Test model (PT model) } \\
\hline & $\begin{array}{l}\text { Layer } \\
\text { number }\end{array}$ & $\begin{array}{l}\text { Layer } \\
\text { thickness } \\
\text { (ft) }\end{array}$ & $\begin{array}{l}\text { Horizontal hydraulic } \\
\text { conductivity }\left(\mathrm{K}_{\mathrm{h}}\right) \\
\text { (ft/d) }\end{array}$ & $\begin{array}{l}\text { Transmissivity } \\
\text { (ft'/d) }\end{array}$ & $\begin{array}{l}\text { Calibrated horizontal } \\
\text { hydraulic conductivity }\left(\mathrm{K}_{\mathrm{h}}\right) \\
(\mathrm{ft} / \mathrm{d})\end{array}$ & $\begin{array}{c}\text { Calibrated } \\
\text { transmissivity } \\
\left(\mathrm{ft}^{2} / \mathrm{d}\right)\end{array}$ \\
\hline Maquoketa Shale confining unit & 2 & 110 & 0.10 & 11 & 0.04 & 4.75 \\
\hline Sinnipee Group aquifer/confiing unit & 3 & 137 & 1.01 & 138 & 0.44 & 59.78 \\
\hline Ancell Group aquifer unit & 4 & 213 & 5.54 & 1,180 & 2.39 & 509.77 \\
\hline Prairie du Chien-Trempealeau Groups aquifer/confining unit & 5 & 100 & 0.22 & 22 & 0.10 & 9.50 \\
\hline Elk Mound Group - Ironton-Galesville aquifer unit & 6 & 97 & 2.67 & 259 & 1.15 & 111.88 \\
\hline Elk Mound Group - Eau Claire aquifer/confining unit & 7 & 69 & 1.15 & 79 & 0.50 & 34.28 \\
\hline Elk Mound Group - Mount Simon aquifer unit & 8 & -- & -- & -- & -- & -- \\
\hline \multirow[b]{3}{*}{ Stratigraphic unit } & & 726 & & 1,690 & & 730 \\
\hline & & & \multicolumn{2}{|c|}{ Lake Michigan model (LMB model) } & \multicolumn{2}{|c|}{ LMB modified model } \\
\hline & $\begin{array}{l}\text { Layer } \\
\text { number }\end{array}$ & $\begin{array}{l}\text { Layer } \\
\text { thickness } \\
\text { (ft) }\end{array}$ & $\begin{array}{l}\text { Horizontal hydraulic } \\
\text { conductivity }\left(\mathrm{K}_{\mathrm{h}}\right) \\
\text { (ft/d) }\end{array}$ & $\begin{array}{l}\text { Transmissivity } \\
\quad\left(\mathrm{ft}^{2} / \mathrm{d}\right)\end{array}$ & $\begin{array}{l}\text { Horizontal hydraulic } \\
\text { conductivity }\left(\mathrm{K}_{\mathrm{h}}\right)^{1} \\
\text { (ft/d) }\end{array}$ & $\begin{array}{c}\text { Model } \\
\text { transmissivity } \\
\left(\mathrm{ft}^{2} / \mathrm{d}\right)\end{array}$ \\
\hline Maquoketa Shale confining unit & 13 & 315 & 0.10 & 31.50 & 0.06 & 18.55 \\
\hline Sinnipee Group aquifer/confiing unit & 14 & 142 & 1.01 & 143.42 & 0.59 & 84.47 \\
\hline Ancell Group aquifer unit & 15 & 132 & 5.54 & 731.28 & 3.26 & 430.72 \\
\hline Prairie du Chien-Trempealeau Groups aquifer/confining unit & 16 & 132 & 0.22 & 29.04 & 0.13 & 17.10 \\
\hline Elk Mound Group - Ironton-Galesville aquifer unit & 17 & 84 & 2.67 & 224.28 & 1.57 & 132.10 \\
\hline Elk Mound Group - Eau Claire aquifer/confining unit & 18 & 69 & 1.15 & 79.35 & 0.68 & 46.74 \\
\hline Elk Mound Group - Mount Simon aquifer unit & 19 & -- & -- & -- & -- & -- \\
\hline Total & & 874 & & 1,239 & & 730 \\
\hline \multicolumn{7}{|c|}{$\begin{array}{l}{ }^{1} \text { The LMB modified model } \mathrm{K}_{\mathrm{h}} \text { values were determined by multiplying LMB model } \mathrm{K}_{\mathrm{h}} \text { values by a factor }(0.589) \text { that will result in transmissivity of the entire Cambrian-Ordovician aquiver system }(\mathrm{COAS}) \\
\text { in the LMB modified model to equal the calibrated transmissivity of the entire COAS from the Pumping Test model }\left(730 \mathrm{ft}^{2} / \mathrm{d}\right) \text {. }\end{array}$} \\
\hline
\end{tabular}


Table 5-3. Updated values of specific storage and storativity for combined Cambrian-Ordovician units in the Pumping Test model and local area of the Lake Michigan Basin modified model. Thickness values include 4 feet assigned to the Mount Simon aquifer at the Hatchery location. For local area of the Lake Michigan Basin model, see figure $5-2$.

[Exponential notation is used to express some values for specific storage and storativity]

\begin{tabular}{lccc}
\hline \multirow{2}{*}{ Groundwater-flow model } & \multicolumn{2}{c}{ Units of the Cambrian-Ordovician aqufier system } \\
\cline { 2 - 4 } & $\begin{array}{c}\text { Thickness } \\
\text { (feet) }\end{array}$ & $\begin{array}{c}\text { Specific storage } \\
\text { (1/feet) }\end{array}$ & $\begin{array}{c}\text { Storativity } \\
\text { (unitless) }\end{array}$ \\
\hline Pumping Test model & 730 & $1.65 \mathrm{E}-07$ & $1.20 \mathrm{E}-04$ \\
Pumping Test model - calibrated & 730 & $2.96 \mathrm{E}-07$ & $2.16 \mathrm{E}-04$ \\
Lake Michigan Basin model - local area & 878 & $1.65 \mathrm{E}-07$ & $1.44 \mathrm{E}-04$ \\
Lake Michigan Basin modified model - local area & 878 & $2.46 \mathrm{E}-07$ & $2.16 \mathrm{E}-04$ \\
\hline
\end{tabular}

The drawdown at the nearest competing wells completed in the COAS, the Campbellsport production well \#4 located about $9 \mathrm{mi}$ west of the hatchery property, reflects the regional effect of the proposed pumping center at the hatchery property. Scenario 1 has wells PW1 and PW2 pumping at a combined average yearly rate of $800 \mathrm{gal} / \mathrm{min}$ for 20 years. The drawdown in the potentiometric surface, as expressed by the 5 - $\mathrm{ft}$ contour in figure 18 , extends into neighboring counties and under Lake Michigan. The simulated drawdown at the Campbellsport production well \#4 is $16.9 \mathrm{ft}$ after 20 years (fig. 19). Because of the relatively large distance between the hatchery property and the Campbellsport well, the results would be nearly identical if the candidate wells were located more precisely at the center of more than one LMB modified model cell. Scenario 2 has wells PW1, PW2, and PW3 pumping at a combined average yearly rate of $900 \mathrm{gal} / \mathrm{min}$ for 20 years. The drawdown in the potentiometric surface, similar to Scenario 1, is shown in figure 20. The simulated drawdown at the Campbellsport production well \#4 is $19.0 \mathrm{ft}$ after 20 years (fig. 21).

As discussed in the main text, the predicted regional drawdown in the LMB modified model is combined with the borehole drawdown predicted by the PT model to evaluate the feasibility of the design for supply wells completed in the COAS supporting hatchery operations.

\section{References}

Anderson, M.P., Woessner, W.W., and Hunt, R.J., 2015, Applied groundwater modeling: Simulation of flow and advective transport ( $2 \mathrm{~d}$ ed.): Elsevier Science, 564 p.

Feinstein, D.T., Hunt, R.J., and Reeves, H.W., 2010, Regional groundwater-flow model of the Lake Michigan Basin in support of Great Lakes Basin water availability and use studies: U.S. Geological Survey Scientific Investigations Report 2010-5109, 379 p.

Konikow, L.F., Hornberger, G.Z., Halford, K.J., and Hanson, R.T., 2009, Revised multi-node well (MNW2) package for MODFLOW ground-water flow model: U.S. Geological Survey Techniques and Methods book 6, chap. A30, 67 p. 



\section{Appendix 6. Application of Kettle Moraine Springs (KMS) Model to Silurian Aquifer Water Supply Scenarios}


The Kettle Moraine Springs (KMS) model is a tool for determining how much groundwater can be withdrawn from the Silurian aquifer at the hatchery without violating management goals (such as maintaining base flow in streams or minimizing groundwater-level declines at on-property and off-property wells). The model was applied in two steps:

1. Formal optimization modeling was performed by combining a linearized (confined) version of the groundwater-flow model with linear programming techniques to explore the range of feasible options; and

2. The findings of the constrained optimization simulations were applied to the unconfined version of the model to test specific scenarios and estimate optimal pumping rates at selected pumping well locations.

The following sections further describe the two-step optimization approach.

\section{Constrained Optimization with Confined Version of Kettle Moraine Springs (KMS) Model}

The constrained optimization problem at the Kettle Moraine Springs State Fish Hatchery (KMSSFH) consists of achieving objectives associated with maximizing pumping from target well locations subject to constraints associated with minimally acceptable groundwater fluxes and water levels. Optimization of groundwater withdrawals with the MODFLOW Groundwater Management (GWM) package allowed for determination of withdrawal locations and pumping rates that best met the specified management objective (maximize withdrawal) and a series of constraints (limited drawdown and streamflow reductions). Specifically, well locations and pumping rates were selected to maximize pumping. The groundwater-management program GWM-2005 (Ahlfeld and others, 2009) uses a response-matrix approach in a linear programming framework to solve linear, nonlinear, and mixed-binary linear constrained optimization formulations based on a MODFLOW groundwater-flow model. Each formulation consists of a set of decision variables, an objective function, and a set of constraints. The success of the formulation in defining the space of feasible solutions depends on a linear relation between perturbations in the decision variables (pumping rates) and the response of constraints in terms of changes in fluxes and water levels. An unconfined flow model in which the available transmissivity is a function of the water level solution can yield nonlinear, and, consequently, unstable responses for different sized perturbations. A confined model is more likely to yield a stable solution to the optimization problem for a given set of decision variables, objectives, and constraints.

The KMS model is unconfined (all layers "convertible" constructed for MODFLOW-2005 with the NWT solver) with multi-node wells and with stream cells inserted using the SFR2 package. To simplify the problem and make the optimization more linear (Sheets and others, 2014), the steadystate model is set to confined conditions (that is, constant transmissivity) for all layers (with the layer 1 top equal to the original steady-state head solution). Other simplifying changes included constructing the model for MODFLOW-2000 (with the PCG solver, representing existing wells through the WEL [well] package and surface-water features through the STR [stream] package).

The objective function to be maximized is the total pumping rate from a candidate network of "managed" wells open to the Silurian dolomite. The decision variables are the withdrawal rates from candidate well locations chosen by representatives of the Wisconsin Department of Natural Resources (WDNR). As part of the input to GWM-2005, options were invoked to set a "lower bound" and "upper bound" associated with each candidate well to 100 gallons per minute ( $\mathrm{gal} / \mathrm{min}$ ) and $500 \mathrm{gal} / \mathrm{min}$, respectively, and to allow only a maximum number of candidate locations (typically three) to be assigned any pumping at all.

Three additional types of constraints were employed in the optimization:

1. A maximum reduction in collected spring flow and a downgradient stream base-flow reduction of 14 percent (a threshold commonly enforced by the WDNR) relative to the flow simulated without the candidate wells;

2. A 5-foot (ft) drawdown limit at nearby household well locations to protect local pumping; and

3. A drawdown limit in the candidate pumping wells to ensure that the level inside the borehole is always at least $5 \mathrm{ft}$ above the bottom of the weathered part of the Silurian aquifer.

The last constraint requires the use of the Multi-Node Well (MNW2) package with GWM-2005 for the candidate wells to simulate the water level inside the borehole as a function of aquifer loss and well loss (Ahlfeld and Barlow, 2013). Existing wells are simulated using the simpler MODFLOW WEL package, which does not compute or report the borehole water level, only the average water level in the grid cell. All the candidate wells are simulated as multi-node wells penetrating both the 50-ft thick weathered Silurian horizon (layer 4) and the underlying Silurian thickness (layer 5). The skin effect is represented by an assumed disturbed annulus $0.5 \mathrm{ft}$ thickness assigned a hydraulic conductivity of 2 feet/day (ft/d).

The solution to the optimization problem in GWM depends on a response matrix, which is determined by perturbing the pumping rates and calculating the effects of the perturbed pumping rate on each of the flow and drawdown constraints (Ahlfeld and Barlow, 2013). For linear systems, the response coefficients (Rs) are independent of the perturbation magnitude. A nonlinear system is not independent of the perturbation magnitude, and an iterative process is used to converge to a final set of coefficients. This problem proved 
nonlinear despite the imposed confined conditions primarily because of the presence of head-dependent boundaries representing the stream and spring network. Initial tests assuming a linear system and a relatively large perturbation amount $($ DELTA $=4.0)$ resulted in part of the surface-water network drying up and a very nonlinear response. Tests with smaller perturbations (for example, DELTA=0.5) produced reasonable Rs values but different Rs values for different DELTA values. Tests using the GWM option "Sequential Linear Programming," which modifies the perturbation for each iteration based on a set of solver parameters (for example, initial perturbation $=0.2$, rate of change $=2$, convergence criteria $=1 \mathrm{e}^{-4)}$ yielded stable solutions.

The value of the GWM process was that it helped identify well locations and pumping rates that could provide the most water to the hatchery with minimal water-level declines at nearby wells. A general consideration for locating candidate wells is the greater the distance between wells, the less the pumping from each will impact the other. This consideration along with individual site considerations (topography, proximity to surface water, infrastructure requirements) resulted in the WDNR Fisheries prioritizing six candidate locations to be considered in pumping scenarios. These locations are labeled TOP1, TOP2, TOP3, ALT1, ALT2, and ALT3 (fig. 8).

Six optimization simulations were performed with GWM-2005:

1. Silu8: pumping maximized from 3 of 6 candidate wells, all constraints active except the spring-flow constraint;

2. Silu8a: same as Silu8 but pumping maximized for only 2 of 6 candidate wells;

3. Silu8b: same as Silu8 but the six candidate wells only penetrate the top weathered layer of the Silurian aquifer;

4. Silu8c: same as Silu8 but with spring-flow constraint active;

5. Silu8d: same as Silu8 but with three well locations specified (TOP1, TOP2, TOP3); and

6. Silu8e: same as Silu8 but neither the spring nor the creek base-flow constraint is active.

The sequential linear programming algorithm achieves optimal solutions for all six cases, meeting every assigned constraint. The total withdrawals achieved and the candidate wells selected for each simulation are:

Silu8: $\quad 534 \mathrm{gal} / \mathrm{min}$ from TOP1 (232 gal/min), TOP3 (159 gal/min), and ALT2 (143 gal/min);

Silu8a $\quad 483 \mathrm{gal} / \mathrm{min}$ from TOP1 (289 $\mathrm{gal} / \mathrm{min})$ and TOP3 (194 gal/min);

Silu8b $\quad 508 \mathrm{gal} / \mathrm{min}$ from TOP1 (255 gal $/ \mathrm{min})$, TOP3 (138 gal $/ \mathrm{min})$, and ALT2 (115 gal $/ \mathrm{min})$;
Silu8c $449 \mathrm{gal} / \mathrm{min}$ from TOP2 $(181 \mathrm{gal} / \mathrm{min})$, TOP3 (166 gal/min), and ALT2 (102 $\mathrm{gal} / \mathrm{min})$;

Silu8d $492 \mathrm{gal} / \mathrm{min}$ from TOP1 (294 gal/min) and TOP2 (198 gal $/ \mathrm{min})$; and

Silu8e $\quad 534 \mathrm{gal} / \mathrm{min}$ from TOP1 (232 gal/min), TOP3 (159 gal/min), and ALT2 (143 gal/min).

Each solution depends on a subset of constraints that bind the solution; that is, the constraints that are exactly met and therefore limit allowable pumping. The most common binding constraints pertain to the existing onsite pumping wells (a 5-ft drawdown limit) and to the pond just north of the property (a head limit that enforces no more than a 14-percent reduction in the unmanaged groundwater discharge to this water body). Note also that total withdrawal and the distribution of pumping among the selected wells in the optimized solution are identical for cases Silu8 and Silu8e. The reason for the identical solutions is that the presence of the creek base-flow constraint in case Silu8 makes no difference because it is not binding.

\section{Optimal Solutions with Unconfined Kettle Moraine Springs (KMS) Model}

The confined version of the KMS model, while useful for exploring the effect of Silurian pumping on local head and flux conditions through linearized optimization techniques, must give way to the original model, which provides a more realistic representation of the unconfined conditions that exist in the shallow flow system. Pumping from the Silurian aquifer decreases the saturated thickness of the shallow flow system and therefore decreases its transmissivity. It follows that a confined model, which maintains the saturated thickness constant, will tend to underestimate drawdown from pumping and hence overestimates water availability; the unconfined (and less linear) base version discussed in appendix 4 tends to give a more reliable assessment of water availability.

The second step in the optimization analysis was to use the GWM-2005 results with the confined KMS model as a guide for evaluating scenarios with the unconfined KMS model. The starting point was a simulation using the unconfined version of the KMS model in which none of the six Silurian candidate wells were pumping. This simulation is named "BaseCase" and provides the base-line values for surface-water flow and water levels in wells against which the constraints are measured. Three of the constrained optimization scenarios that were solved with GWM-2005 were reevaluated; these three scenarios span the range of optimized pumping. The minimum pumping scenario is named "AllConstraints" (confined run was named "Silu8c") in which all constraints are active, including the constraint on reduction of existing flow from hatchery springs (STRMCON_11). The pumping scenario in which all constraints are active except 
flow from hatchery springs at STRMCON_11 is named "Constraints2" (confined run was named "Silu8"). The pumping scenario in which all constraints are active except flow from hatchery springs at STRMCON 11 and flow at the Melius Creek confluence (STRMCON_21) is named "Constraints3" (confined run was named "Silu8e").

The AllConstraints simulation shows that in the presence of pumping from candidate wells, the spring-flow constraint at STRMCON_11 limits the reduction of groundwater discharge to the local springs to less than 14 percent of the simulated discharge of the BaseCase, without candidate wells. The decision to include or exclude this constraint will depend on the characterization of the existing spring flow. Engineered structures already capture the existing discharge and route it through the hatchery operations before it flows into Melius Creek. Shallow pumping would divert spring flow before it discharges and route it to hatchery operations, whereupon most or nearly all of it would discharge to Melius Creek. If it is judged important to maintain the hatchery-fed spring flow at a level of at least 86 percent of simulated rates of the BaseCase, then a scenario similar to that tested in AllConstraints should be implemented. Otherwise, the scenarios in which the STRMCON_11 constraint is inactive, Constraints 2 and Constraints3, can be considered.

Starting with scenarios Silu8, Silu8c, and Silu8e, a trial-and-error approach was adopted to modify the pumping rates for use with the unconfined model to identify the greatest pumping rates under the constraints defined in the three scenarios-

AllConstraints, Constraints2, and Constraints 3 . The unconfined KMS model invokes the Newton-Raphson solver to avoid dry cell problems caused by the water-table solution. It also represents the candidate Silurian wells with the MODFLOW MNW2 package in order to predict the borehole water level and taking account of aquifer loss within the cells occupied by a well and the skin effect associated with a moderately disturbed annular zone around the borehole. The well-by-well results reflect how consideration of unconfined conditions reduce the optimized rates achieved with the confined version of the model. The total rates compare as follows (as presented in the main text):

\section{Simulated total discharge (gallons per minute) optimized with GWM-2005 and the confined KMS model}

\begin{tabular}{lll}
\hline Silu8c & 449 & optimized with AllConstraints \\
Silu8 & 534 & optimized with Constraints2 \\
Silu8e & 534 & optimized with Constraints3
\end{tabular}

Simulated discharge (gallons per minute) achieved with the unconfined KMS model, total and by well

\begin{tabular}{lll}
\hline Silu8c & 430 & $($ TOP $2=150$, TOP $3=180$, ALT2 $=100)$ \\
Silu8 & 480 & $($ TOP $1=180$, TOP $3=160$, ALT2 $=140)$ \\
Silu8e & 520 & $($ TOP $1=230$, TOP $3=160$, ALT2 $=130)$
\end{tabular}

Note that the total maximum pumping for cases Silu8 and Silu8e differed when simulated with the unconfined KMS model; the optimization analysis using the confined model yielded identical rates. The elimination of the creek base-flow constraint in case Silu8e, leading to a reduction in headwater creek flow of more than 14 percent, under unconfined conditions allows for more total pumping and a different distribution of pumping among candidate wells relative to the optimized solution using the confined version of the model.

The evaluation of water availability to the hatchery from the Silurian aquifer subject to local constraints is performed applying the KMS model under steady-state conditions. All sources and sinks to the model, including pumping from the candidate wells, are maintained at constant levels. No consideration is taken of the likelihood that over part of the year the shallow system will operate at rates lower than the $430-520 \mathrm{gal} / \mathrm{min}$ level established by the analysis and allow fluxes and water levels to partly recover. In this sense, the analysis is conservative.

\section{References}

Ahlfeld, D.P., Baker, K.M., and Barlow, P.M., 2009, GWM2005-A Groundwater-Management Process for MODFLOW-2005 with Local Grid Refinement (LGR) capability: U.S. Geological Survey Techniques and Methods book 6, chap. A33, 65 p.

Ahlfeld, D.P., and Barlow, P.M., 2013, Use of multi-node wells in the Groundwater-Management Process of MODFLOW-2005 (GWM-2005): U.S. Geological Survey Techniques and Methods, book 6, chap. A47, $26 \mathrm{p}$. [Also available at $\mathrm{http} / / /$ pubs.usgs.gov/tm/06/a47/.]

Sheets, R.A., Hill, M.C., Haitjema, H.M., Provost, A.M., and Masterson, J.P., 2014, Simulation of water-table aquifers using specified saturated thickness: Groundwater, v. 53, issue 1, p. 151-157. 
For more information concerning this report contact:

Director

U.S. Geological Survey / Wisconsin Water Science Center 8505 Research Way

Middleton, Wisconsin 53562

608-821-3817

https://www.usgs.gov//wi-water 
